\title{
RECONNAISSANCE INVESTIGATION
}

OF WATER QUALITY, BOTTOM

SEDIMENT, AND BIOTA

ASSOCIATED WITH IRRIGATION

DRAINAGE IN THE SAN JUAN

RIVER AREA, SAN JUAN COUNTY,

NORTHWESTERN NEW MEXICO,

1990-91

By Paul J. Blanchard, U.S. Geological Survey;

Richard R. Roy, U.S. Fish and Wildlife Service; and

Thomas F. O'Brien, U.S. Fish and Wildlife Service

U.S. GEOLOGICAL SURVEY

Water-Resources Investigations Report 93-4065

U.S. GEOLOGICAL SURVEY

U.S. FISH AND WILDLIFE SERVICE

U.S. BUREAU OF RECLAMATION

U.S. BUREAU OF INDIAN AFFAIRS

Albuquerque, New Mexico

1993

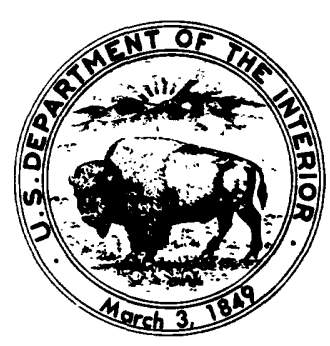


U.S. DEPARTMENT OF THE INTERIOR

BRUCE BABBITT, Secretary

U.S. GEOLOGICAL SURVEY

Da11as L. Peck, Director

For additional information write to:

District Chief

U.S. Geological Survey

Water Resources Division

4501 Indian School Road NE, Suite 200

Albuquerque, New Mexico 87110
Copies of this report can be purchased from:

U.S. Geological Survey Books and Open-File Reports Federal Center Box 25425

Denver, Colorado 80225 


\section{CONTENTS}

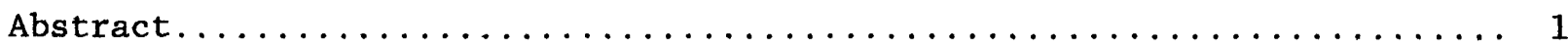

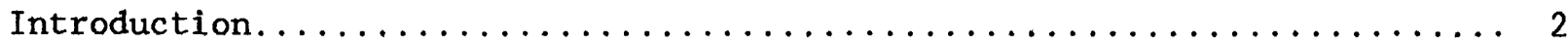

Purpose and scope...............................

Acknowledgments ................................

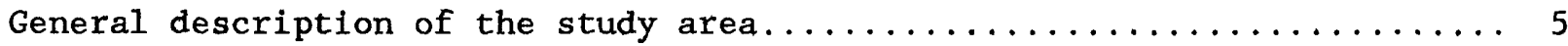

Department of Interior-sponsored irrigation projects............7

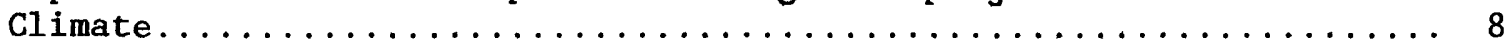

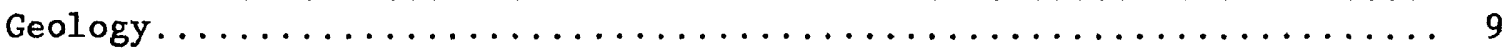

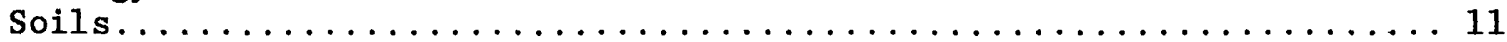

Hydrologic setting ...............................11

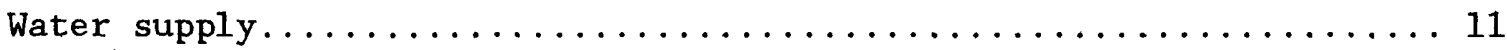

Hydrology of Department of Interior-sponsored irrigation projects... 13

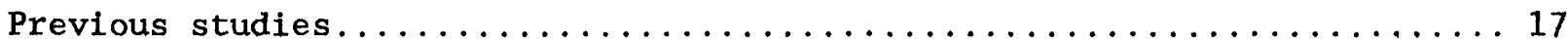

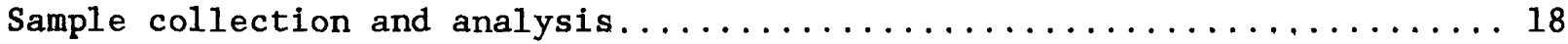

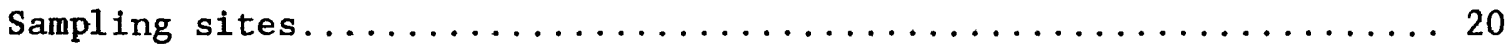

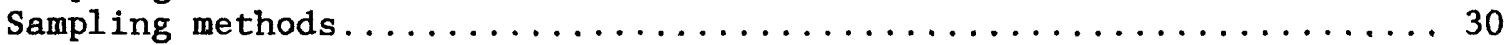

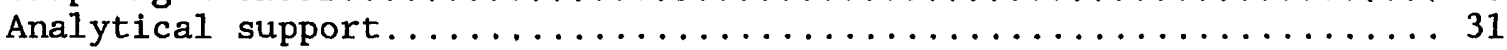

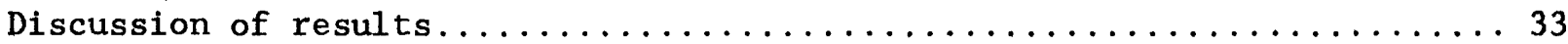

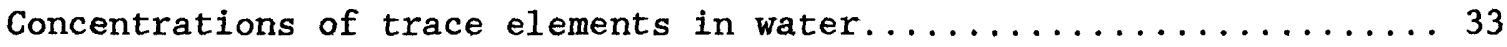

Concentrations of trace elements in bottom sediment............39

Concentrations of trace elements in biota...................

Pond and wetland community members...................42

Fish in the San Juan River......................47

Birds....................................... 54

Concentrations of pesticides in water................... 59

Concentrations of pesticides in bottom sediment..............59

Concentrations of pesticides in biota..................... 59

Fish in the San Juan River.........................60

Birds.....................................60

Concentrations of hydrocarbons in water..................62

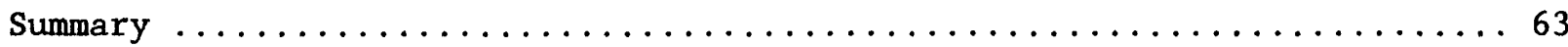

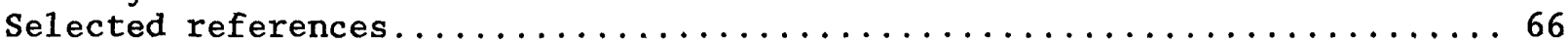

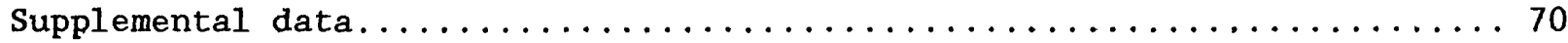




\section{FIGURES}

Figure 1. Map showing the San Juan River area, Department of Interior-sponsored irrigation projects, and streamflow-

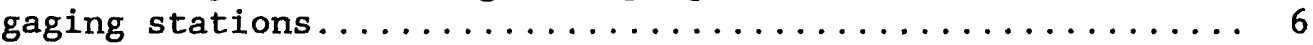

2. Graph showing median of average monthly precipitation and 1990 monthly precipitation at four locations in the San Juan River area....................... 8

3. Map showing geology of the San Juan River area........... 10

4. Map showing irrigation water delivery system on the Nava jo Indian Irrigation Project................. 14

5. Schematic diagram of the water distribution systems on the Hammond, Fruitland, Hogback, and Cudei Irrigation Projects.. 16

6. Map showing energy resource areas and production activities in the San Juan River area................ 19

7. Map showing water-quality, bottom-sediment, and biota sampling sites on or adjacent to Department of Interior-sponsored irrigation projects...............

8. Map showing water-quality and bottom-sediment sampling sites and fish-sampling reaches on the San Juan River and at the mouths of tributary streams.......... 24

9. Box plot showing concentrations of dissolved selenium in water samples from irrigation project sites........... 37

10. Box plot showing distribution of concentrations of selenium in all species of suckers collected for the National Contaminant Biomonitoring Program (NCBP) in 1984, and in flannelmouthed suckers from the San Juan River in $1990 \ldots \ldots 50$

11. Box plot showing distribution of concentrations of copper in carp collected for the National Contaminant Biomonitoring Program (NCBP) in 1984 and from the San Juan River in 1990

12. Box plot showing distribution of concentrations of lead in all species of suckers collected for the National Contaminant Biomonitoring Program (NCBP) in 1984, and in flannelmouthed suckers from the San Juan River in 1990..... 52

13. Box plot showing distribution of concentrations of mercury in all species of suckers collected for the National Contaminant Biomonitoring Program (NCBP) in 1984, and in flannelmouthed suckers from the San Juan River in 1990.... 53

14. Box plot showing concentrations of selenium in adult birds collected from the San Juan River area.............. 56 


\section{TABLES}

Table 1. Streamflow-gaging stations, period of record, and average

discharge in the San Juan River area................. 12

2. Schedule of major crop irrigated acreage on the Navajo Indian Irrigation Project...................... 15

3. Sampling ("I") sites located on or adjacent to

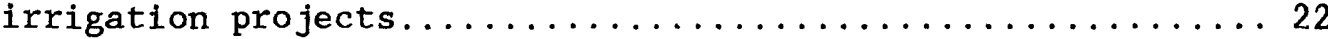

4. San Juan River reaches from which fish samples were collected, and water and bottom-sediment sampling ("R") sites within each river reach..................... 25

5. Number of samples and types of analyses for media at sampling sites on irrigation projects, the San Juan River, and tributaries....................... 26

6. Number of bird samples collected for analysis of inorganic constituents at sites on irrigation projects...... 28

7. Types of analyses conducted on fish samples from reaches of the San Juan River........................... 29

8. Laboratory reporting levels for selected constituents in water and bottom sediment..................... 32

9. Comparison of baseline concentrations of selected constituents in samples collected from rivers of the United States with concentrations in 28 samples from the San Juan River, diversions, and tributaries, and in 48 samples from

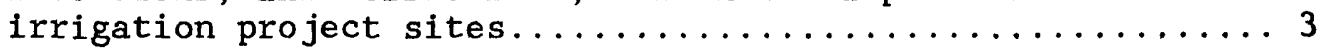

10. U.S. Environmental Protection Agency and State of New Mexico water-quality standards for selected constituents......... 35

11. Concentrations of selected trace elements in soils of the Western United States, in soils from the San Juan Basin, in bottom sediment from 19 National Irrigation WaterQuality Program (NIWQP) study areas, and in bottom sediment from the San Juan River area............... 40

12. Ranges of whole-body concentrations of selected trace elements in biota from pond and wetland sites...........43

13. Selenium concentration ranges and medians for pond and wetland community media..................... 44

14. Pond and wetland sites in which the concentrations of selenium in biota exceeded food-item criteria........... 45

15. Comparison of concentrations of trace elements in fish samples collected for the National Contaminant Biomonitoring Program (NCBP) with samples collected from the San Juan River in 1990 


\section{TABLES --Concluded}

Table 16. Summary of selenium concentrations in adult bird liver and kidney tissue at each sampling site or group of

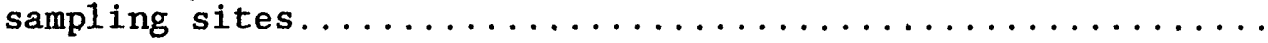

17. Number of bird embryo samples in each of three seleniumconcentration categories at each sampling site or group of

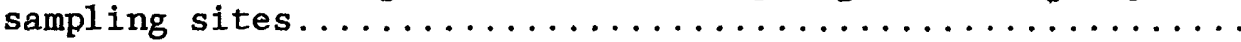

18. Comparison of acetylcholinesterase (AChE) activity in brain tissue of bird samples collected in the San Juan River area with diagnostic ranges of $\mathrm{AChE}$ activity..........

19. Cholinesterase activity in brain tissue and blood serum of adult drake mallard samples collected on the Navajo Indian Irrigation Project in mid-May 1990 and from

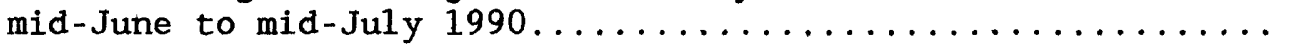

20. Streamflow, selected properties, and concentrations of selected constituents in water samples: spring, summer,

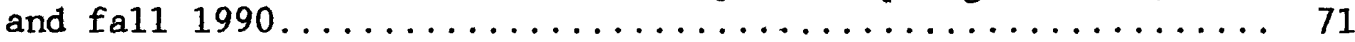

21. Streamflow and concentrations of trace elements in water samples: spring, summer, and fall 1990.............

22. Concentrations of selected constituents in bottom

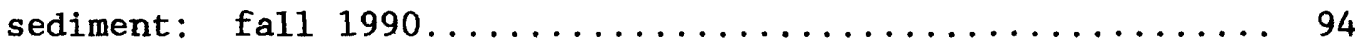

23. Concentrations of selected constituents in plant, invertebrate, amphibian, and fish samples collected from ponds and wetlands: summer 1990

24. Concentrations of selected constituents in composite samples of whole-body fish from the San Juan River: spring and fall 1990.

25. Concentrations of selected constituents in individual edible-portion fish samples from the San Juan River: 1990

26. Concentrations of selected constituents in livers and kidneys of bird samples: spring 1990.

27. Concentrations of pesticides in water and bottom-sediment samples: 1990.

28. Concentrations of organochlorine compounds in composite whole-body flannelmouthed sucker samples: 1990.

29. Concentrations of organochlorine compounds in individual

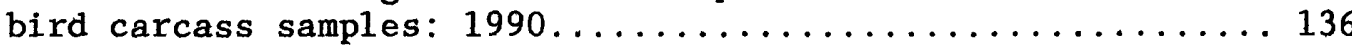

30. Cholinesterase enzyme activity in brain tissue and blood serum of birds: $1990 \ldots \ldots \ldots \ldots \ldots \ldots \ldots \ldots \ldots \ldots \ldots$. . . . . . . . . . . . . . . 


\section{Multiply}

acre (acre)

acre-foot (acre-ft)

cubic foot per second $\left(\mathrm{ft}^{3} / \mathrm{s}\right)$

foot ( $\mathrm{ft}$ )

gallon per minute (gal/min)

inch (in.)

mile (mi)

quart (qt)
By

To obtain

0.4047

0.001233

0.02832

0.3048

3.748

25.40

1.609

0.937 hectare

cubic hectometer

cubic meter per second meter

liter per minute

millimeter

kilometer

liter

Temperature in degrees Celsius $\left({ }^{\circ} \mathrm{C}\right)$ can be converted to degrees Fahrenheit $\left({ }^{\circ} \mathrm{F}\right)$ as follows: ${ }^{\circ} \mathrm{F}=1.8\left({ }^{\circ} \mathrm{C}\right)+32$.

Specific conductance is reported in microsiemens per centimeter $(\mu \mathrm{S} / \mathrm{cm})$ at 25 degrees Celsius.

Chemical concentrations in water are reported in milligrams per liter $(\mathrm{mg} / \mathrm{L})$ or in micrograms per 1iter $(\mu \mathrm{g} / \mathrm{L})$, which are equivalent to parts per million and parts per billion, respectively, when concentrations are less than about 7,000 milligrams per 1iter.

Chemical concentrations in sediment are reported in micrograms per gram $(\mu \mathrm{g} / \mathrm{g}))$ or in micrograms per kilogram $(\mu \mathrm{g} / \mathrm{kg})$, which are equivalent to parts per million and parts per billion, respectively.

Chemical concentrations in biota are reported in micrograms per $\operatorname{gram}(\mu \mathrm{g} / \mathrm{g})$, or micrograms per kilogram $(\mu \mathrm{g} / \mathrm{kg})$, which are equivalent to parts per million and parts per billion, respectively. 


\author{
RECONNAISSANCE INVESTIGATION OF WATER QUALITY, BOTTOM SEDIMENT, \\ AND BIOTA ASSOCIATED WITH IRRIGATION DRAINAGE IN THE SAN JUAN \\ RIVER AREA, SAN JUAN COUNTY, NORTHWESTERN NEW MEXICO, 1990-91 \\ By Paul J. Blanchard, U.S. Geological Survey; \\ Richard R. Roy, U.S. Fish and Wildlife Service; and \\ Thomas F. O'Brien, U.S. Fish and Wildlife Service
}

\begin{abstract}
Selenium is the trace element of major concern in the San Juan River area. Concentrations of selenium larger than established standards and criteria were present in water, bottom sediment, and biota in four areas on three irrigation projects: the middle and north ponds in Gallegos Canyon on the Navajo Indian Irrigation Project (NIIP) (two sites), the ojo Amarillo Canyon drainage on the NIIP (two sites), a pond receiving irrigation drainage water on the West Hammond Irrigation Project (one site), and a drain on the eastern part of the Hogback Irrigation Project (one site). Ground-water return flow from irrigated areas contributes substantially to surface water at these sites.

Selenium concentrations in nine surface-water samples collected from these sites exceeded the U.S. Environmental Protection Agency Primary Drinking Water Standard Maximum Contaminant Level of $50 \mu \mathrm{g} / \mathrm{L}$ (micrograms per 1iter). One additional sample concentration also exceeded the State of New Mexico standard of $5 \mathrm{\mu g} / \mathrm{L}$ designated for the protection of fisheries.

Selenium concentrations in five bottom-sediment samples from the middle pond in Gallegos Canyon, Ojo Amarillo Canyon, and the Hogback Project ranged from 4.5 to $37 \mu \mathrm{g} / \mathrm{g}$ (micrograms per gram). The geometric mean concentration of selenium in soils of the Western United States is $0.23 \mu \mathrm{g} / \mathrm{g}$.

Selenium concentrations in biota at six sites in Gallegos and 0 jo Amarillo Canyons, the West Hammond Pond, and the Hogback east drain ranged from 3.0 to $32.3 \mu \mathrm{g} / \mathrm{g}$ in eight invertebrate samples, 4.22 to $51.3 \mu \mathrm{g} / \mathrm{g}$ in five amphibian samples, and 13.6 to $41.7 \mu \mathrm{g} / \mathrm{g}$ in six fish samples. Selenium concentrations in 18 of these 19 samples were within or larger than the 4- to $8-\mu \mathrm{g} / \mathrm{g}$ dry-weight waterfowl food-item criterion. Six fish samples from these sites also had concentrations larger than the $12-\mu \mathrm{g} / \mathrm{g}$ whole-body concentration above which reproductive failure can occur.
\end{abstract}


The largest median concentrations of selentum in bird liver and kidney tissue were in six bird samples from the Gallegos Canyon ponds $(31.2 \mu \mathrm{g} / \mathrm{g})$ and

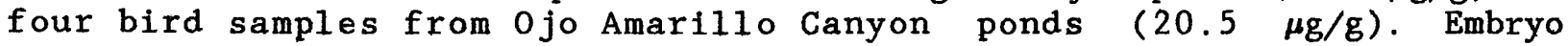
deformities usually occur when the median selenium concentration in a population is larger than $30 \mu \mathrm{g} / \mathrm{g}$; however, the potential for embryo deformities exists when the concentration of selenium is between 10 and 30 $\mu \mathrm{g} / \mathrm{g}$. Due to lack of availability, however, only one embryo from the Gallegos and Ojo Amarillo Canyons was examined for teratogenesis. The results of embryo examinations conducted during this study, therefore, are inadequate to accurately determine conditions throughout the San Juan River area.

Eleven of 15 plant samples, 6 of 15 invertebrate samples, and 4 of 14 fish samples collected from irrigation project sites had concentrations of lead larger than the criterion for predator protection of about $1 \mu \mathrm{g} / \mathrm{g}$ dry weight. Four of 13 common carp and flannelmouthed sucker samples had lead concentrations and 4 of 13 flannelmouthed sucker samples had mercury concentrations larger than the respective 85th-percentile concentrations in these species collected for the National Contaminant Biomonitoring Program (NCBP).

Concentrations of DDE were larger than laboratory reporting levels in 8 of 10 bottom-sediment samples, 6 of 6 flannelmouthed sucker samples, and 31 of 35 bird samples. In 8 of 16 killdeer samples, concentrations of DDE were equal to or larger than the $1.0-\mu \mathrm{g} / \mathrm{g}$ wet-weight criterion for the protection of predators. No concentration in any of the 22 organochlorine compound analyses in the six fish samples was as large as the respective NCBP geometric mean concentration.

\section{INTRODUCTION}

During the last several years, there has been increasing concern about the quality of irrigation drainage and its potentially harmful effects on human health, fish, and wildlife. Concentrations of selenium greater than water-quality criteria for the protection of aquatic life (U.S. Environmental Protection Agency, 1987) have been detected in subsurface drainage from irrigated land in the western part of the San Joaquin Valley in California. In 1983, incidences of mortality, birth defects, and reproductive failures in waterfowl were discovered by the U.S. Fish and Wildiffe Service at the Kesterson National Wildlife Refuge in the western San Joaquin Valley where irrigation drainage was impounded. In addition, potentially toxic trace elements and pesticide residues have been detected in other areas in western States that receive irrigation drainage.

Because of concerns expressed by the U.S. Congress, the U.S. Department of the Interior (DOI) started a program in October 1985 to identify the nature and extent of irrigation-induced water-quality problems that might exist in the western States. The DOI developed a management strategy and formed an interbureau group known as the "Task Group on Irrigation Drainage," which prepared a comprehensive plan for reviewing irrigation-drainage concerns for which DOI may have responsibility. 
Initially, the task group identified 20 areas in 13 states that warranted reconnaissance-level investigations related to three specific activities: (1) irrigation or drainage facilities constructed or managed by the DOI, (2) National Wildlife Refuges managed by the DOI, and (3) other migratory-bird or endangered-species management areas that receive water from DOI-funded projects.

Nine of the 20 areas were selected for reconnaissance investigations during 1986-87:

$\begin{aligned} \text { Arizona-California: } & \text { Lower Colorado-Gila River Valley area } \\ \text { California: } & \text { Salton Sea area } \\ & \text { Tulare Lake Bed area } \\ \text { Montana: } & \text { Sun River Reclamation Project area } \\ & \text { Milk River Reclamation Project area } \\ \text { Nevada: } & \text { Stillwater Wildlife Management area } \\ \text { Texas: } & \text { Lower Rio Grande-Laguna Atascosa } \\ & \text { National Wildlife Refuge area } \\ \text { Utah: } & \text { Middle Green River Basin area } \\ \text { Wyoming: } & \text { Kendrick Reclamation Project area. }\end{aligned}$

Reports for these nine reconnaissance investigations have been published. On the basis of results of these investigations, four detailed studies were initiated in 1988 for the Salton Sea area, Stillwater Wildlife Management area, Middle Green River Basin area, and the Kendrick Reclamation Project area.

Eleven more reconnaissance investigations were initiated in 1988:

California: Sacramento Refuge Complex

California-Oregon: Klamath Basin Refuge Complex

Colorado: Gunnison and Uncompahgre River Basins and Sweitzer Lake

Pine River Project

Colorado-Kansas: Middle Arkansas River Basin

Idaho: $\quad$ American Falls Reservoir

New Mexico: Middle Rio Grande Project and Bosque del Apache National Wildlife Refuge

Oregon: Malheur National Wildlife Refuge

South Dakota: Angostura Reclamation Unit

Belle Fourche Reclamation Unit

Wyoming: Riverton Reclamation Project.

Evaluation of results in published reports of these investigations, and a continuing evaluation of all data for the Irrigation Drainage Program led to initiating three more detailed studies in 1990-91:

California-Oregon: Klamath Basin Refuge Complex

Colorado: Gunnison River Basin/Grand Valley Project

Montana: Sun River area. 
In October 1989, four reconnaissance investigations were begun and another was started in October 1990. The study areas are:

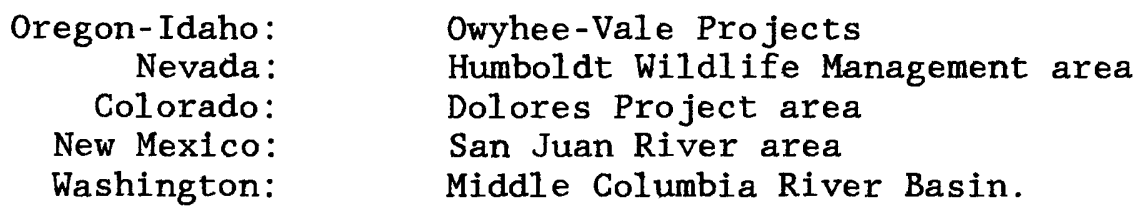

All reconnaissance investigations are conducted by interbureau study teams composed of a scientist from the U.S. Geological Survey as team leader, with additional Geological Survey, U.S. Fish and Wildlife Service, U.S. Bureau of Reclamation, and U.S. Bureau of Indian Affairs scientists representing several different disciplines. The investigations are directed toward determining whether irrigation drainage: (1) has caused or has the potential to cause significant harmful effects to human health, fish, and wildlife; or (2) may adversely affect the suitability of water for other beneficial uses.

\section{Purpose and Scope}

The purpose of this report is to present information for determining if irrigation drainage from the DOI-sponsored irrigation projects in the San Juan River area: (1) has caused or has the potential to cause significant harmful effects to human health, fish, or wildlife; or (2) may reduce the suitability of water for beneficial uses. The San Juan River area was selected for study because data from previous studies in the area indicated that concentrations of some inorganic and organic substances may be large enough to cause or have the potential to cause these harmful effects or to reduce the suitability of water for beneficial uses. Additionally, the geologic units of the area, consisting of primarily sedimentary formations of Cretaceous and Tertiary age, have the potential to yield significant amounts of selenium and other trace elements to water, bottom sediment, and biota.

The scope of this study included collection and analysis of water, bottom-sediment, and biota samples from the San Juan River upstream and downstream from and adjacent to the DOI-sponsored irrigation projects; from diversions from the San Juan River; and from wetlands, ponds, and streams within and at areas of discharge of the irrigation projects, including backwater habitats. Sample collection was conducted from April 1990 through December 1990. Samples were analyzed for concentrations of major ions, selected trace elements, and selected pesticides. Acute toxicity tests were conducted on water samples from selected sites to determine the toxicity of water to selected organisms. This report describes the areal distribution of concentrations of selected constituents in the various media and how these concentrations relate to irrigation drainage from the DOI-sponsored irrigation projects. 


\section{Acknowledgments}

Appreciation is extended to Ernest Teller and Phillip Tollenaar of the Agricultural Testing and Research Laboratory, Navajo Agricultural Products Industry, for use of laboratory facilities; to Jeffrey Cole, Navajo Nation Fish and Wildlife, for assistance in obtaining sample collection permits; to Raymond Smith, U.S. Bureau of Indian Affairs, for assistance in field sampling and sample preparation; and to Leif Ahlm, State of New Mexico Department of Game and Fish, for providing housing and work space. The authors also thank Sky Bristol, volunteer, U.S. Fish and Wildlife Service, for contributions throughout the study.

\section{GENERAL DESCRIPTION OF THE STUDY AREA}

The San Juan River area is located in San Juan County, northwestern New Mexico (fig. 1). The area includes an approximately $90-\mathrm{mi}$ reach of the San Juan River valley from Navajo Dam, about $30 \mathrm{mi}$ upstream from Farmington, New Mexico, to the mouth of the Mancos River, about $25 \mathrm{mi}$ downstream from Shiprock, New Mexico, and an adjacent upland area. The upland area is south of the San Juan River valley, approximately bounded by the Chaco River on the west, Hunter Wash on the south, and New Mexico State Highway 44 on the east.

The San Juan River and adjacent wetlands provide habitat for endangered species, native southwestern fish species, sportfish, and the plant and animal communities on which they depend. About 200 species of birds are at least partially dependent on the riparian habitat along the San Juan River; of these, about 100 species are directly dependent on this habitat for survival and reproduction (Meneely and others, 1979).

The Federally endangered bald eagle (Haliaeetus leucocephalus), peregrine falcon (Falco peregrinus), Colorado squawfish (Ptychocheilus lucius), and razorback sucker (Xyrauchen texanus) are known to live in the San Juan Basin (Meneely and others, 1979). Species designated by the State of New Mexico as endangered and known to inhabit the San Juan Basin include three mammal, eight bird, two amphibian, and four fish species (Meneely and others, 1979).

Wildlife surveys are conducted routinely in the San Juan River drainage by the New Mexico Department of Game and Fish. During the winter 1991-92 surveys, as many as 33 bald eagles, 17,900 Canada geese, and 11,800 ducks were observed in the San Juan River drainage (Donald MacCarter, New Mexico Department of Game and Fish, written commun., 1992). 


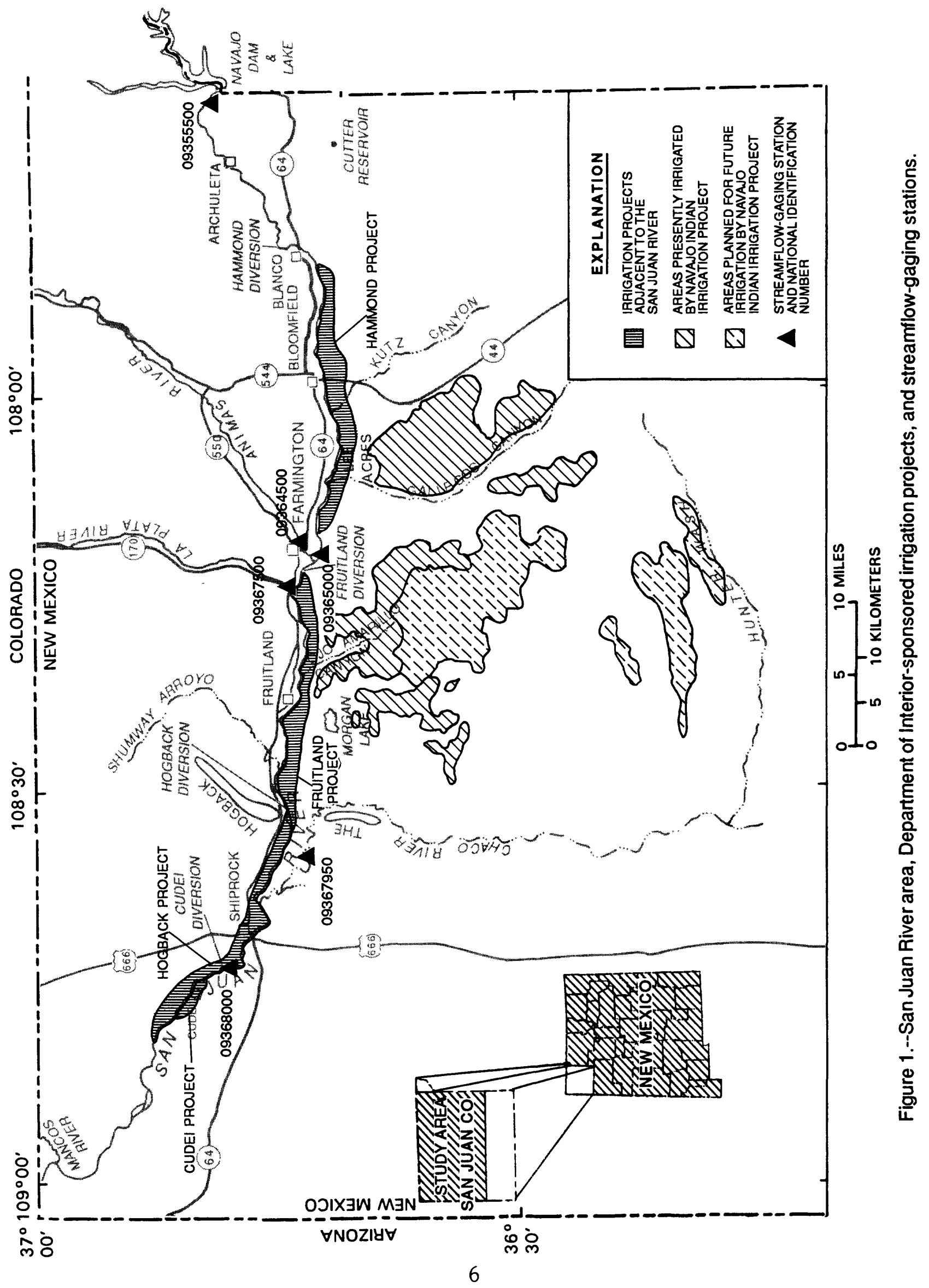




\section{Department of Interior-Sponsored Irrigation Projects}

Five DOI-sponsored irrigation projects are located in the area: the Navajo Indian Irrigation Project (NIIP) (fig. 1), the Hammond Irrigation Project, the Fruitland Irrigation Project, the Hogback Irrigation Project, and the Cudei Irrigation Project. The NIIP was authorized in 1962 and construction of the project began in 1973. It is operated and maintained by the Navajo Nation. The project is divided into 11 blocks, and each block typically contains about 8,000 to 12,000 acres of cropland. Presently (1992), development of 6 blocks is complete and about 50,000 acres are being irrigated; when all 11 blocks are developed, about 110,000 acres will be irrigated. Irrigation of the first six blocks began between 1976 and 1982 (Robert Krakow, U.S. Bureau of Indian Affairs, ora1 commun., 1990). Construction of the delivery system to the blocks is the responsibility of the U.S. Bureau of Reclamation; construction of the on-farm delivery and drainage systems are the responsibility of the U.S. Bureau of Indian Affairs in cooperation with the Navajo Nation.

The Hammond Irrigation Project is located in a narrow strip south of and adjacent to the San Juan River, from about $2 \mathrm{mi}$ southwest of Blanco to about 2 mi southeast of Farmington ( $f i g .1$ ). It was constructed by the U.S. Bureau of Reclamation; irrigation began in 1962 (U.S. Bureau of Reclamation, written commun., 1980). The project is operated and maintained by the Hammond Conservancy District. The project provides irrigation for about 3,900 acres. About 700 acres within the present project area were irrigated prior to 1962.

The Fruitland Irrigation Project is located south of and adjacent to the San Juan River, from about $2 \mathrm{mi}$ west of Farmington to about $2 \mathrm{mi}$ west of The Hogback (fig. 1). Irrigation in the project area began in 1910, and the present project was completed in the early 1940's. The project provides irrigation for about 3,300 acres (Jerry Thomas, U.S. Bureau of Indian Affairs, oral commun., 1991).

The Hogback Irrigation Project is located north of and adjacent to the San Juan River, from The Hogback, about $8 \mathrm{mi}$ east of Shiprock, to about $10 \mathrm{mi}$ northwest of Shiprock (fig. 1). Irrigation in the project area began in 1904 and most of the original project was completed by about 1940. A pumping plant and two main laterals were added in 1952. The project provides irrigation for about 7,000 acres (Jerry Thomas, oral commun., 1991).

The Cudei Irrigation Project is located south of and adjacent to the San Juan River, from about 5 mi northwest of Shiprock to about $2 \mathrm{mi}$ northwest of Cudei (fig. 1). Irrigation in the project area began in about 1910 . The project provides irrigation for about 540 acres (Jerry Thomas, oral commun., 1991). 


\section{Climate}

The climate of the San Juan River area is semiarid to arid and is characterized by large daily fluctuations in temperature and small annual precipitation. For the period 1931 to 1978, the average maximum and minimum temperatures at Farmington were 42 and $14^{\circ} \mathrm{F}$ in January and 94 and $57^{\circ} \mathrm{F}$ in July (Dr. Kenneth E. Kunkel, New Mexico Department of Agriculture, written commun., 1984). The growing season is approximately 160 days.

Average annual precipitation on the San Juan River area ranges from 6.6 in. at Shiprock to 8.5 in. at Bloomfield. Nearly half of the annual precipitation falls during July through October, usually during intense thunderstorms. Average annual potential evaporation is 79 in. at Navajo Dam and 77 in. at Farmington (Marjorie Chafey, U.S. Weather Service, written commun., 1980).

In 1990, precipitation was about 131 percent of normal annual precipitation (U.S. Department of Commerce, 1990). Precipitation in April, May, August, and September 1990 was more than 0.50 in. more than average; precipitation was 0.25 in. less than average in July and October 1990 . The average annual precipitation and average monthly precipitation are the median values of annual and monthly averages of four stations in the San Juan River area: Bloomfield, Farmington, Fruitland, and Shiprock. The periods of record at these stations range from 44 to 51 years; the last year included was 1981 . The median values of average monthly and 1990 monthly precipitation are shown in figure 2.

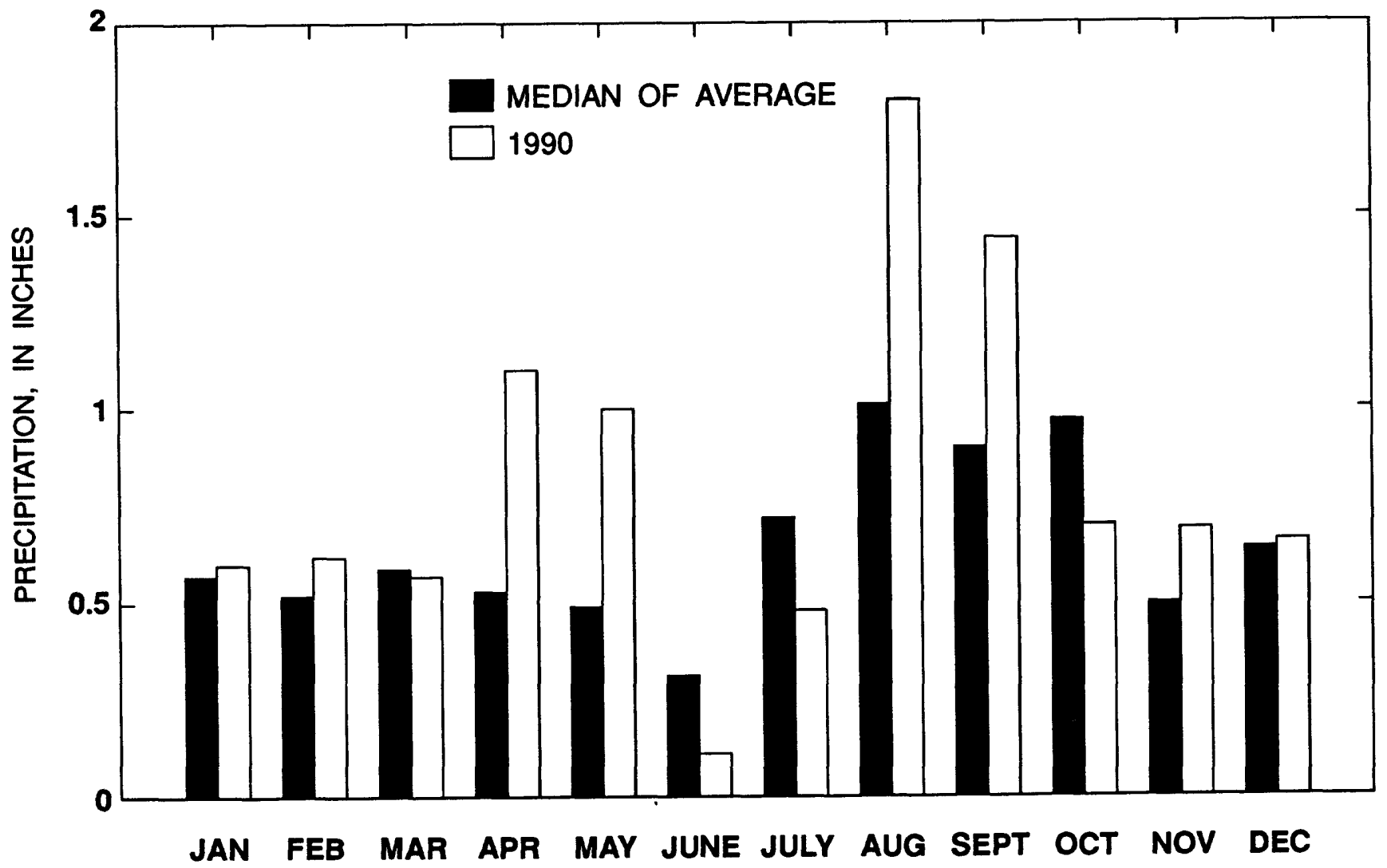

Figure 2.--Median of average monthly precipitation and 1990 monthly precipitation at four locations in the San Juan River area. 


\section{Geology}

The San Juan River area lies within the Navajo section of the Colorado Plateaus physiographic province (Fenneman, 1931). The Navajo section is characterized by mesas, buttes, cuesta ridges, and rock terraces separated by broad, open valleys and occasional canyons and hogbacks. The San Juan River area includes the broad, terraced San Juan River valley where the Hammond, Fruitland, Hogback, and Cudei Irrigation Projects are located, and a large, relatively flat mesa to the south of the San Juan River valley, where the NIIP is located. The San Juan River valley is intersected by The Hogback about 8 mi east of Shiprock (fig. 1). The Hogback is an approximately north trending monocline that dips steeply to the east.

The consolidated-rock surface geology of the San Juan River area includes sedimentary strata ranging from Cretaceous to Tertiary age (fig. 3 ). These strata typically consist of sequences of interbedded sandstone, mudstone, and shale units, and occasional coal deposits. Each of the shale units in these sequences has the potential to contribute dissolved trace elements, including selenium, to the surface-water environment.

The Mancos Shale of Cretaceous age crops out from the western boundary of the study area to just west of The Hogback. The Point Lookout Sandstone, Menefee Formation, Cliff House Sandstone, Lewis Shale, and Pictured Cliffs Sandstone, all of Cretaceous age, crop out within or immediately adjacent to The Hogback.

The Kirtland Shale and Fruitland Formation of Cretaceous age, consisting of a thick sequence of interbedded shale, sandstone, and coal deposits, crops out between The Hogback and Farmington. East of Farmington, the Ojo Alamo Sandstone of Tertiary and Cretaceous age, consisting of sandstone, conglomeratic sandstone, and shale, crops out in north-trending bands about 1 mi wide. The Nacimiento Formation of Tertiary age, consisting of carbonaceous mudstones and sandstones; and the San Jose Formation, consisting of an interbedded sequence of sandstone, siltstone, and variegated shale crop out in most of the study area east of the ojo Alamo Sandstone. The Lewis Shale, Pictured Cliffs Sandstone, Kirtland Shale and Fruitland Formation, Ojo Alamo Sandstone, Nacimiento Formation, and San Jose Formation also crop out in the upland area south of the San Juan River.

The San Juan River valley is characterized by unconsolidated clay, silt, sand, and gravel, and terrace gravel and boulder deposits of Quaternary age. The clay, silt, sand, and gravel deposits probably do not exceed $100 \mathrm{ft}$ in thickness, and the terrace deposits generally do not exceed $30 \mathrm{ft}$ in thickness. 


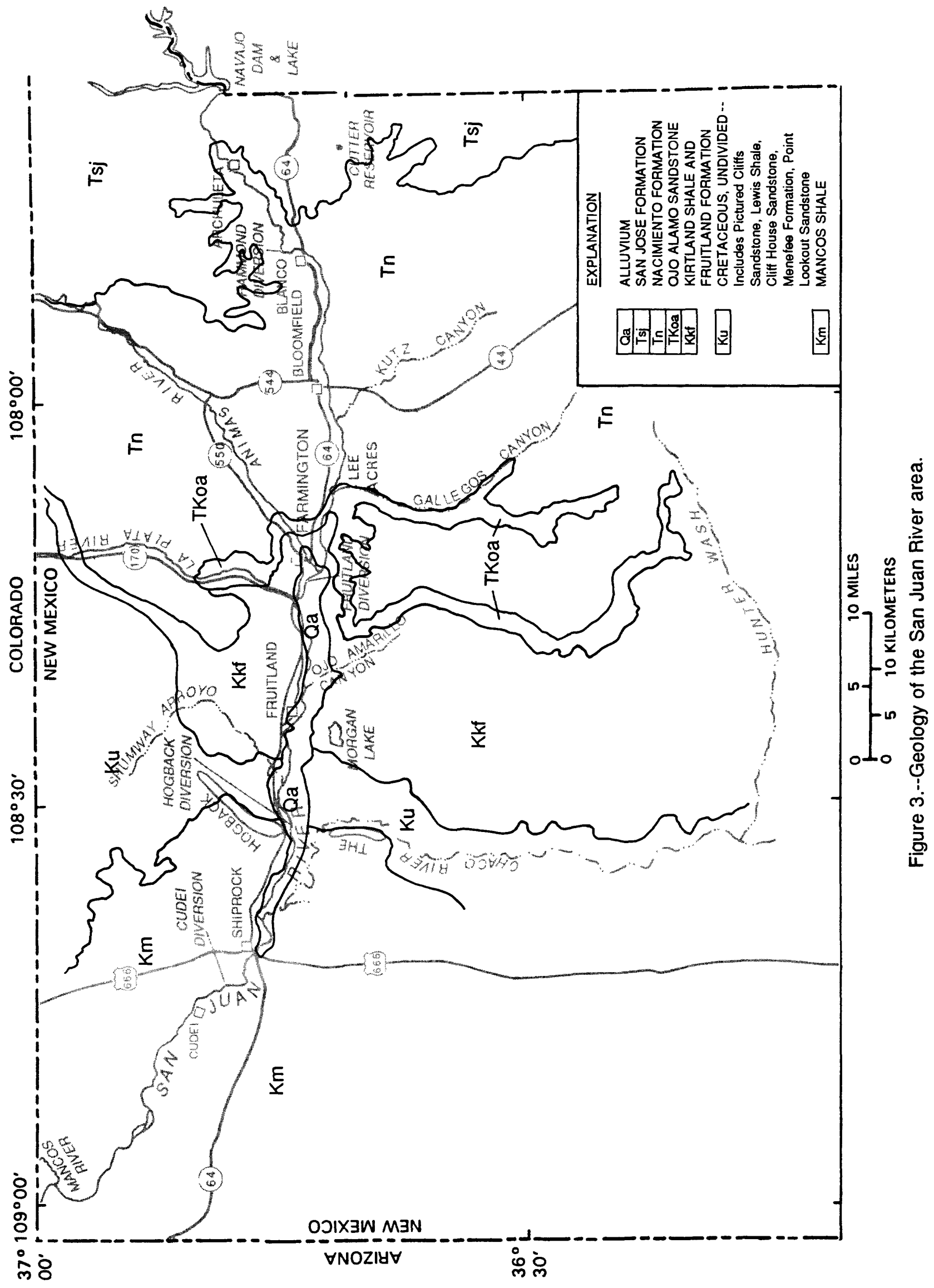




\section{$\underline{\text { Soils }}$}

Soils in the San Juan River valley are derived from alluvial material deposited by the San Juan River and from weathering products of local geologic formations deposited in alluvial fans from side streams. Soil materials typically include sandstone, shale, siltstone, and mudstone. They typically are alkaline, vary in texture from clays to sands, and are poorly stratified. Soils range from poorly to well drained, and permeability ranges from moderately rapid to moderately slow.

Soils in the upland area where the NIIP is located typically are derived from eolian and alluvial material, are deep, and well to excessively drained. Permeability ranges from moderately rapid to rapid.

\section{HYDROLOGIC SETTING}

The headwaters of the San Juan River are in the San Juan Mountains in southwestern Colorado. Spring snowmelt from these mountains provides most of the surface water in the San Juan River area. Most runoff occurs during the spring and early summer snowmelt period, April through early July. Occasional summer thunderstorms also can produce locally large volumes of runoff, particularly in areas of lower altitude. Nearly all water (99 percent) used in San Juan County during 1985 was obtained from surface-water sources (Wilson, 1986).

\section{Water Supply}

About 520,000 acre-ft of water was used in San Juan County in 1985; nearly all of this was surface water used along the corridor of the San Juan River (Wilson, 1986). Irrigation accounted for 78 percent of water use, and power generation accounted for about 10 percent. Virtually all irrigation water is obtained from surface-water sources. The San Juan and Four Corners Power Plants near Shiprock are the primary users of water for power generation. Water supplied by public or private utilities to communities having populations of 2,500 or more, including Bloomfield, Farmington, and Shiprock, accounted for about 2 percent of water used in the county; nearly all of this water was obtained from surface-water sources.

Navajo Dam, on the San Juan River, is about $30 \mathrm{mi}$ upstream from Farmington, and delineates the eastern boundary of the study area ( $f i g .1$ ). Streamflow-gaging stations in the San Juan area are 1isted in table 1 . The average flow in the San Juan River near Archuleta (09355500), about $7 \mathrm{mi}$ downstream from Navajo Dam, was about $1,300 \mathrm{ft}^{3} / \mathrm{s}$ prior to the operation of Navajo Dam in 1963, and has been about $1,200 \mathrm{ft}^{3} / \mathrm{s}$ since operation of the dam began. (U.S. Geological Survey, 1991).

Further downstream, the average flow in the San Juan River at Shiprock $(09368000)$ is about $2,200 \mathrm{ft}^{3} / \mathrm{s}$, based on 64 years of record. Significant tributaries to the San Juan River in the study area and their average annual flow are the Animas River, $920 \mathrm{ft}^{3} / \mathrm{s}$; La Plata River, $29 \mathrm{ft}^{3} / \mathrm{s}$; and Chaco River, $48 \mathrm{ft}^{3} / \mathrm{s}$ (U.S. Geological Survey, 1991). 


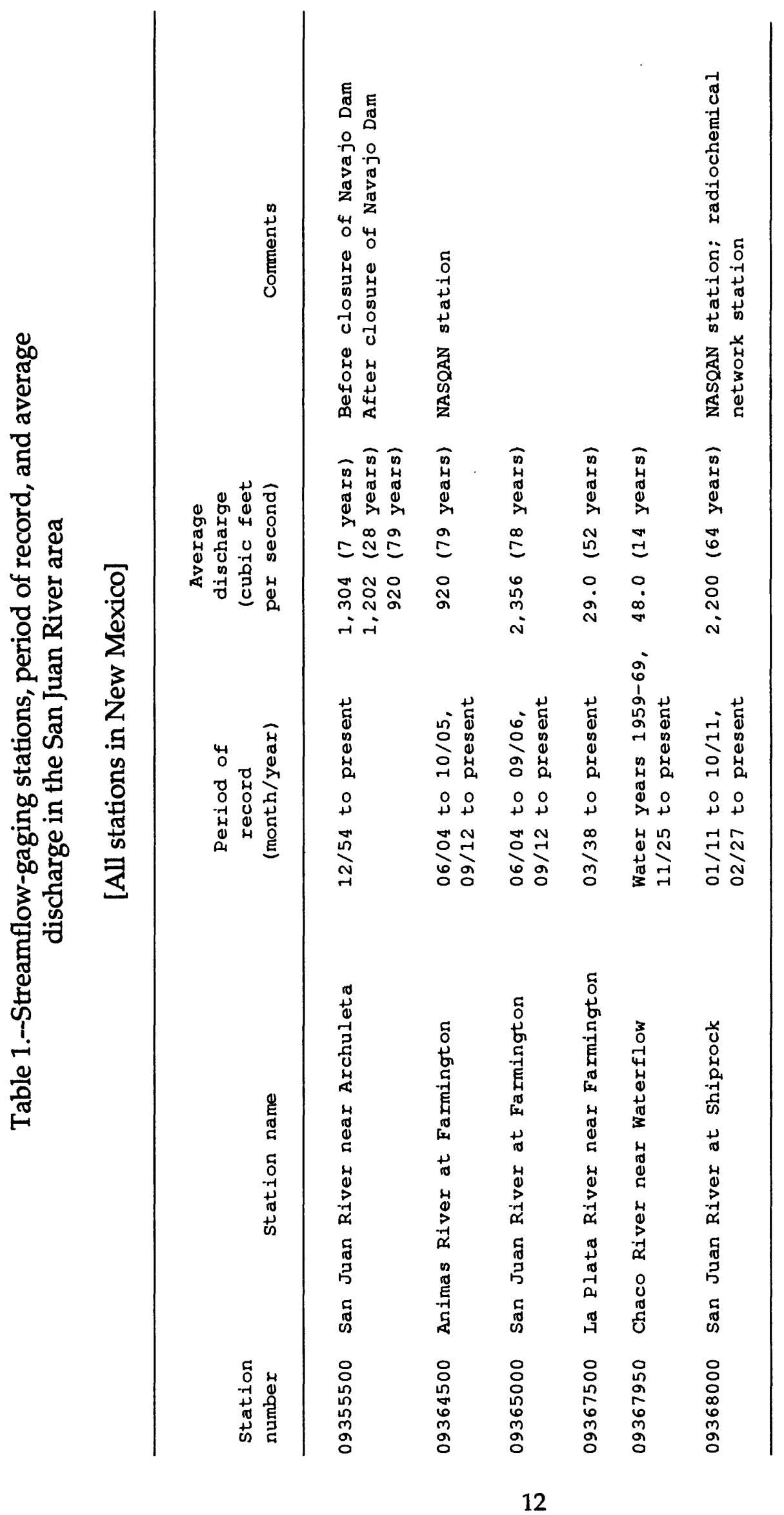


Average flow in the San Juan and Animas Rivers in water year 1990 (October 1, 1989, through September 30,1990) was less than the average annual flow (U.S. Geological Survey, 1991). Flow in the San Juan River near Archuleta was about 45 percent of average annual flow, flow in the San Juan River at Shiprock was about 43 percent of average annual flow, and flow in the Animas River (09364500) was about 56 percent of average annual flow. Flow in the San Juan River is regulated by Navajo Dam; flow in the Animas River is unregulated.

Ground water can be obtained from several geologic units in the area, although the yield of water to wells and the quality of water vary substantially. Wells completed in bedrock units generally yield only a few gallons per minute. Wells completed in unconsolidated units in the San Juan River valley generally yield larger quantities of water, and 1ocally yield more than $100 \mathrm{gal} / \mathrm{min}$. The quality of ground water in some areas makes it unsuitable for domestic or livestock use.

\section{Hydrology of Department of Interior-Sponsored Irrigation Projects}

The five DOI-sponsored irrigation projects divert water from the San Juan River. That portion of the diverted water not consumed by evapotranspiration is returned by overland flow, seepage, or subsurface tile drains to the San Juan River or to the ground-water system in the San Juan River valley. The NIIP consists of a reservoir and a network of main canals, laterals, and pumping stations. The Hammond, Fruitland, Hogback, and Cudei Projects each consist of a diversion, a main canal, and a series of field laterals; the Hammond and Hogback Projects also have pumping plants and main laterals.

Irrigation water for the NIIP is diverted from Navajo Lake on the San Juan River and stored in and regulated by Cutter Reservoir, about $8 \mathrm{mi}$ from Navajo Lake (U.S. Bureau of Reclamation, written commun., 1984). Water is delivered from Cutter Reservoir to the project area about $20 \mathrm{mi}$ away by the Main Canal, which includes several tunnels and siphons. When the NIIP is complete, the project will include about $110 \mathrm{mi}$ of open canals, and the delivery system will carry as much as $1,800 \mathrm{ft}^{3} / \mathrm{s}$. The maximum annual project water allocation is 508,000 acre-ft. The features of the NIIP delivery system are shown in figure 4 .

Primary delivery canals and the irrigation blocks each canal supplies include the Main Canal (blocks 1 and 4), Coury Lateral (block 5), Gravity Main Canal (blocks 2 and 6), and Amarillo Canal (block 3) (fig. 4). The Coury Lateral, Gravity Main Canal, and Amarillo Canal are supplied by the Main Canal (U.S. Bureau of Reclamation, written commun., 1984).

Water is applied to cropland exclusively by sprinkler irrigation systems (Robert Krakow, oral commun., 1991). About 90 percent of the cropland is irrigated by center-pivot systems; the remaining 10 percent is irrigated by wheel-move or hand-move sprinkler systems. The drain system on the NIIP includes about $200 \mathrm{mi}$ of channels to collect storm runoff, overland irrigation-return flow, and ground-water seepage from irrigated land. Gallegos Canyon and Ojo Amarillo Canyon washes (fig. 1) flow to the San Juan River. 


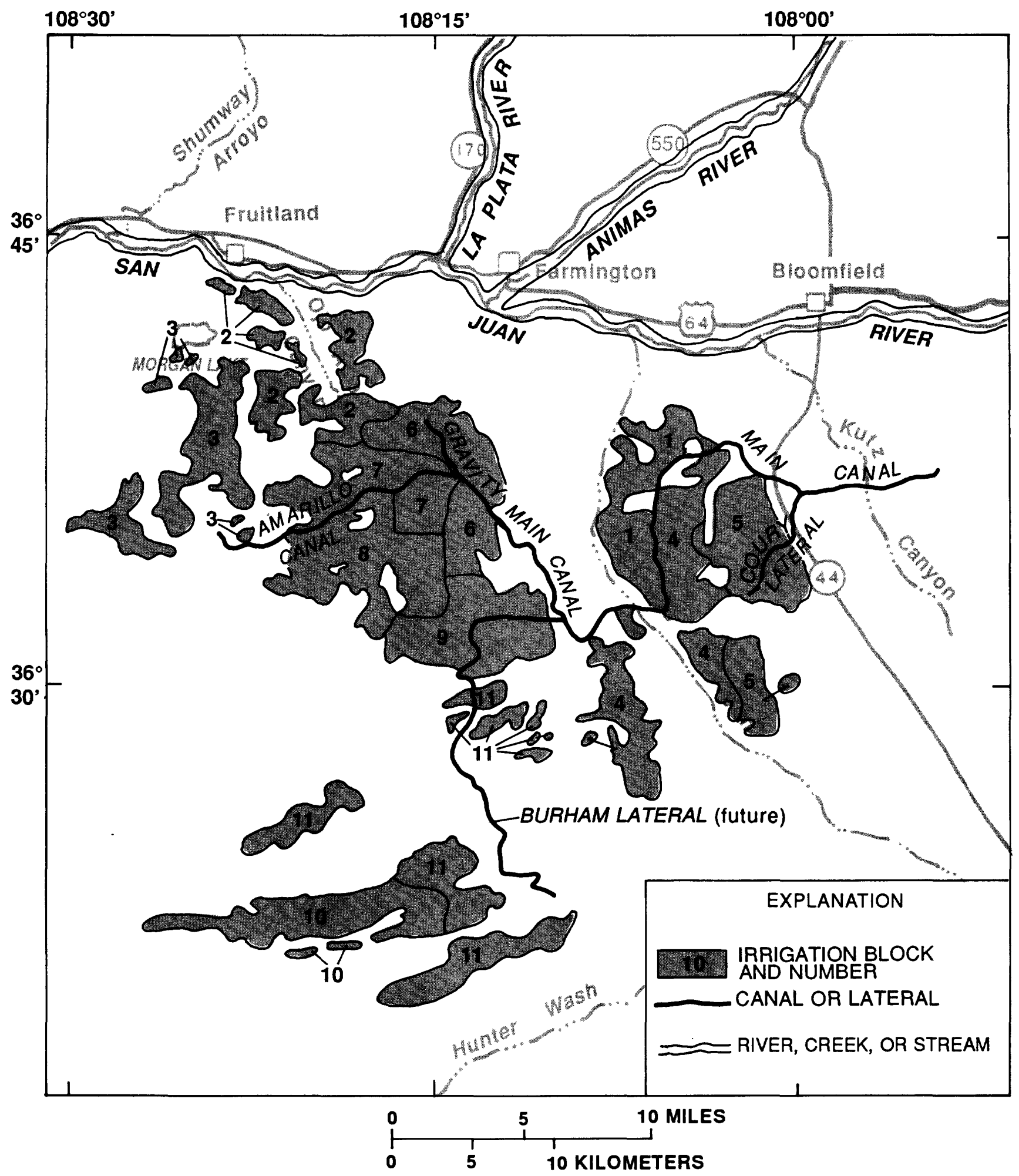

Figure 4.--Irrigation water delivery system on the Navajo Indian Irrigation Project. 
Diversions to the NIIP begin about April 1 and terminate about October 31 of each year. Irrigation begins about April 1 on about 18,000 acres planted in alfalfa, winter wheat, and small grains, about May 1 on about 15,000 acres planted in corn and potatoes, and between May 15 and June 15 on about 10,000 acres planted in beans. Irrigation ceases about July 15 on winter wheat and small grains, about September 15 on beans, about September 30 on corn, and about October 31 on alfalfa and potatoes. About 7,000 acres are planted in miscellaneous crops for which the irrigation season varies. The schedule of major crop acreage under irrigation on the NIIP is listed in table 2.

Table 2.--Schedule of major crop irrigated acreage on the Navajo Indian Irrigation Project

Date

Crops irrigated

Approximate acres irrigated

April 1 to May 1

May 1 to about June 1

June 1 to July 15

July 15 to

September 15

September 15 to

September 30

September 30 to

October 31
Alfalfa, winter wheat, small grains 18,000

Alfalfa, winter wheat, small grains, 33,000 corn, potatoes

Alfalfa, winter wheat, small grains, $\quad 43,000$ corn, potatoes, beans

Alfalfa, corn, potatoes, beans 33,000

Alfalfa, corn, potatoes 23,000

$\begin{array}{ll}\text { Alfalfa, potatoes } & 13,000\end{array}$

The delivery system on the Hammond Irrigation Project consists of the Hammond Diversion on the San Juan River, the Main Gravity Canal, pumping plants, and three major laterals (U.S. Bureau of Reclamation, written commun., 1980). The Main Gravity Canal is about $27 \mathrm{mi} 1$ ong and has an initial capacity of $90 \mathrm{ft}^{3} / \mathrm{s}$. Major diversions from the canal are made by the East and West Highline Laterals, which are served by the Hammond Pumping Plant, the auxiliary pumping plant, and the Gravity Extension Lateral. Croplands generally are served from turnouts on the canal and main laterals; additional short laterals deliver water to isolated croplands. A schematic diagram of the Hammond, Fruitland, Hogback, and Cudei Projects delivery systems is shown in figure 5 .

Water is applied to Hammond Project croplands by flood irrigation and by hand-move and wheel-move sprinkler systems. Drainage from croplands includes ground-water seepage, overland flow, and underground flow through about $8 \mathrm{mi}$ of tile drains located intermittently throughout the project area (Errol Jensen, U.S. Bureau of Reclamation, oral commun., 1990). Ponds and wetlands are located at the outlets of several drain-tile systems. 

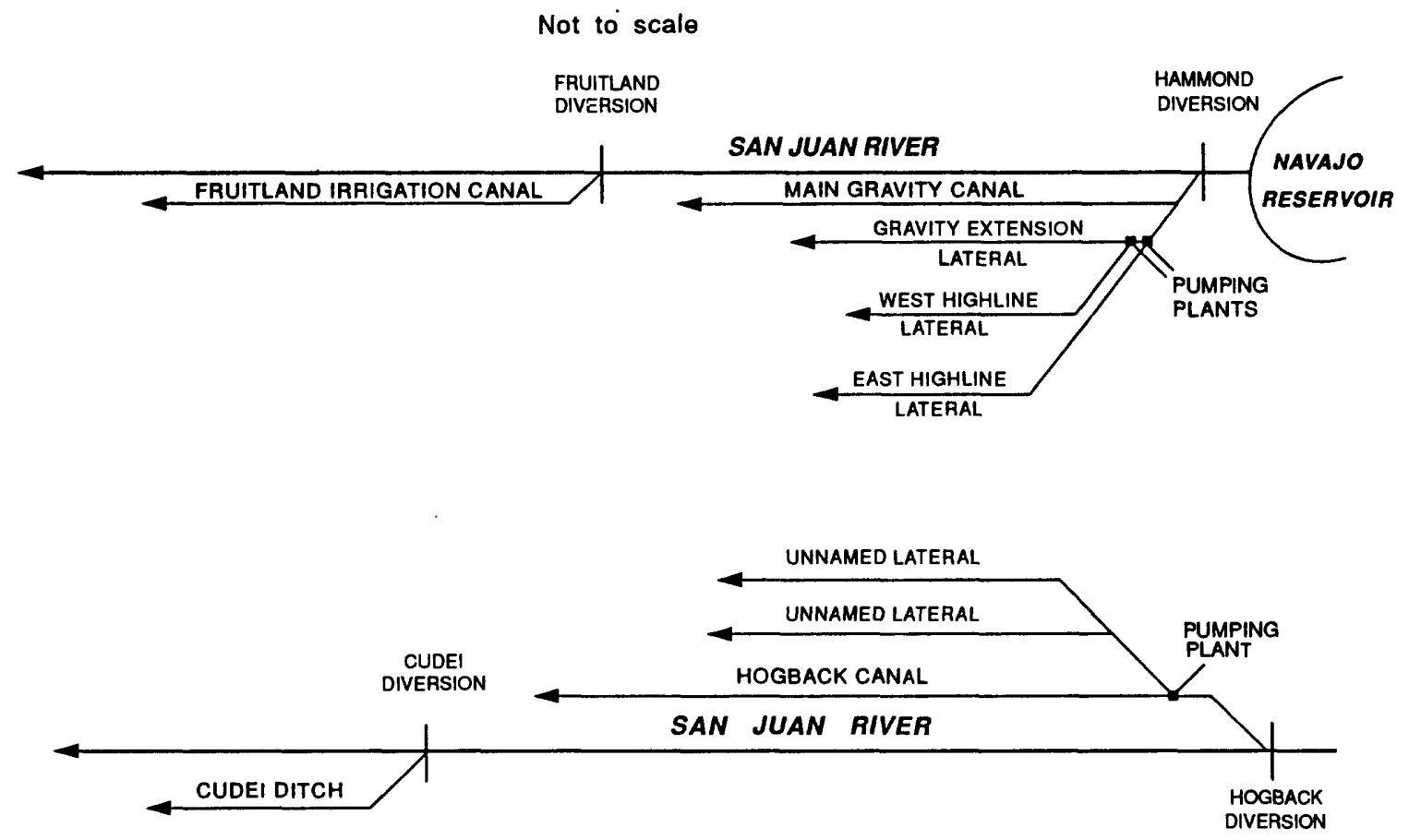

Figure 5.--Schematic diagram of the water distribution systems on the Hammond, Fruitland, Hogback, and Cudei Irrigation Projects.

The Fruitland Irrigation Project delivery system consists of the Fruitland Diversion on the San Juan River $2 \mathrm{mi}$ downstream from Farmington, the Fruitland Irrigation Canal, and about $100 \mathrm{mi}$ of field laterals. The canal is about $23 \mathrm{mi}$ long and has an initial capacity of about $90 \mathrm{ft}^{3} / \mathrm{s}$ (Jerry Thomas, oral commun., 1991). Water is applied primarily by flood irrigation, and drainage is by overland flow and seepage.

The Hogback Irrigation Project delivery system consists of the Hogback Diversion on the San Juan River at The Hogback, the Hogback Canal, a pumping plant, two main laterals; and about $135 \mathrm{mi}$ of field laterals. The Hogback Canal is about $29 \mathrm{mi}$ long and has an initial capacity of $300 \mathrm{ft}^{3} / \mathrm{s}$; typically, about $225 \mathrm{ft}^{3} / \mathrm{s}$ is diverted to the project (Jerry Thomas, oral commun., 1991). Water is applied primarily by flood irrigation, and drainage is by overland flow and seepage.

The Cudei Irrigation Project delivery system consists of the Cudei Diversion on the San Juan River, about 5 mi downstream from Shiprock; the Cudei Ditch; and about $16 \mathrm{mi}$ of field laterals. The Cudei Ditch is about 12 mi long and has an initial capacity of $30 \mathrm{ft}^{3} / \mathrm{s}$ (Jerry Thomas, oral commun., 1991). Water is applied primarily by flood irrigation, and drainage is by overland flow and seepage. 
Ponds and wetlands provide aquatic and riparian habitats on and adjacent to each of the irrigation projects, and irrigation drainage from each project contributes to the flow of the San Juan River. The ponds and wetlands support migratory waterfowl and shorebirds and the plant and animal communities on which they depend. About 15 ponds are located on the NIIP. About 10 ponds intended for stock watering have been created on the NIIP by damming smal1 drainages. These ponds are filled by seepage of irrigation water, irrigation runoff, storm runoff, or diversion of irrigation application water. About five other ponds have been formed by diversion of irrigation application water to small enclosed drainages. Several ponds are part of the Hammond Project, and wetlands connect much of this project to the San Juan River. Wetlands also connect parts of the Fruitland and Hogback Projects to the San Juan River.

\section{PREVIOUS STUDIES}

Data-collection activities, interpretive studies, and Environmental Impact Statements addressing concentrations of potential contaminants in water, sediment, and biota in the San Juan River area have been conducted and prepared by several DOI agencies. These agencies include the U.S. Bureau of Reclamation, the U.S. Bureau of Indian Affairs, the U.S. Fish and Wildlife Service, and the U.S. Geological Survey. Larger-than-expected concentrations of trace elements have been reported by each agency. In addition, the Geological Survey and the Fish and Wildlife Service have reported detectable concentrations of pesticides in water and biota, respectively.

The Bureau of Reclamation reported that elevated levels of unspecified trace elements caused Farmington municipal water intake from the Animas River to be suspended twice between 1975 and 1980 because of accidental contributions of these trace elements from mining areas near the headwaters of the river (U.S. Bureau of Reclamation, 1980). The Bureau of Reclamation also has reported concentrations of lead in the San Juan River at Archuleta, about $7 \mathrm{mi}$ downstream from Navajo Dam, to be larger than the U.S. Environmental Protection Agency (USEPA) Primary Drinking-Water Standard Maximum Contaminant Level (MCL) of $50 \mu \mathrm{g} / \mathrm{L}$ (U.S. Environmental Protection Agency, 1986a). The Bureau of Indian Affairs has monitored ground-water quality on the NIIP since 1985 and has reported concentrations of selenium in ground water as large as $180 \mu \mathrm{g} / \mathrm{L}$ (Robert Krakow, U.S. Bureau of Indian Affairs, written commun., 1990).

Water-quality data collected by the Geological Survey from 1970 through 1989 (U.S. Geological Survey, 1971-90) in the San Juan River area indicate that selenium was present in concentrations larger than $5 \mu \mathrm{g} / \mathrm{L}$ in samples collected from 16 of 24 surface-water-quality stations, from 7 of 35 miscellaneous surface-water sites, and from 4 of 38 miscellaneous ground-water sites. Concentrations of several other trace elements were larger than their respective USEPA Primary Drinking-Water Standard MCL's in surface-water and ground-water samples. 
O'Brien (1987) reported that of 13 starling samples collected in the San Juan River area, concentrations of cadmium in 13 samples, lead in 8 samples, and selenium in 10 samples were larger than the respective National Contaminant Biomonitoring Program (NCBP) geometric mean concentrations (White and others, 1977). Selenium concentrations in 6 of 15 fish samples were above the 85th-percentile concentration of samples from the NCBP, and selenium concentrations in 4 of the 15 samples were between the geometric mean and the 85th-percentile values (Lowe and others, 1985).

Water-quality data collected by the Geological Survey indicate that 2,4,$D$ concentrations have been larger than the laboratory reporting leve1 of 0.01 $\mu \mathrm{g} / \mathrm{L}$ in water samples from the San Juan River at Shiprock (U.S. Geological Survey, 1984-87). O'Brien (1987) reported concentrations of DDE larger than the NCBP geometric mean value (Bunck and others, 1987) in 9 of 14 starling samples and concentrations of polychlorinated biphenyls ( $P C B^{\prime} s$ ) larger than the laboratory reporting level in several species of fish.

\section{SAMPLE COLLECTION AND ANALYSIS}

Sample collection and analysis were designed to determine whether irrigation drainage: (1) has caused or has the potential to cause significant harmful effects to human health, fish, and wildlife; or (2) may adversely affect the suitability of water for other beneficial uses. The potential contaminants of primary interest are trace elements and pesticides.

Other major potential sources of contaminants in the San Juan River area include energy industry activities and non-DOI-sponsored irrigation. Energy industry activities include ofl and gas exploration, extraction, and processing; coal mining; and electric power generation (fig. 6). These activities may contribute to degradation of water quality; additionally, energy industry activities can be the source of potential contaminants that subsequently could be mobilized and transported by irrigation drainage.

About 7,000 acres of irrigated land along the San Juan River in the San Juan River area are not part of DOI-sponsored irrigation projects (Quincy Cornelius, U.S. Bureau of Reclamation, retired, oral commun., 1991). This acreage primarily is located on the north side of the San Juan River valley between Navajo Dam and The Hogback. About 400 acres are located on the south side of the river, upstream from the Hammond Project. Another 21,000 acres of irrigated land along the Animas River in New Mexico are not part of DOIsponsored irrigation projects. Irrigation drainage from any or all of these areas may contribute potential contaminants to the San Juan River area. 


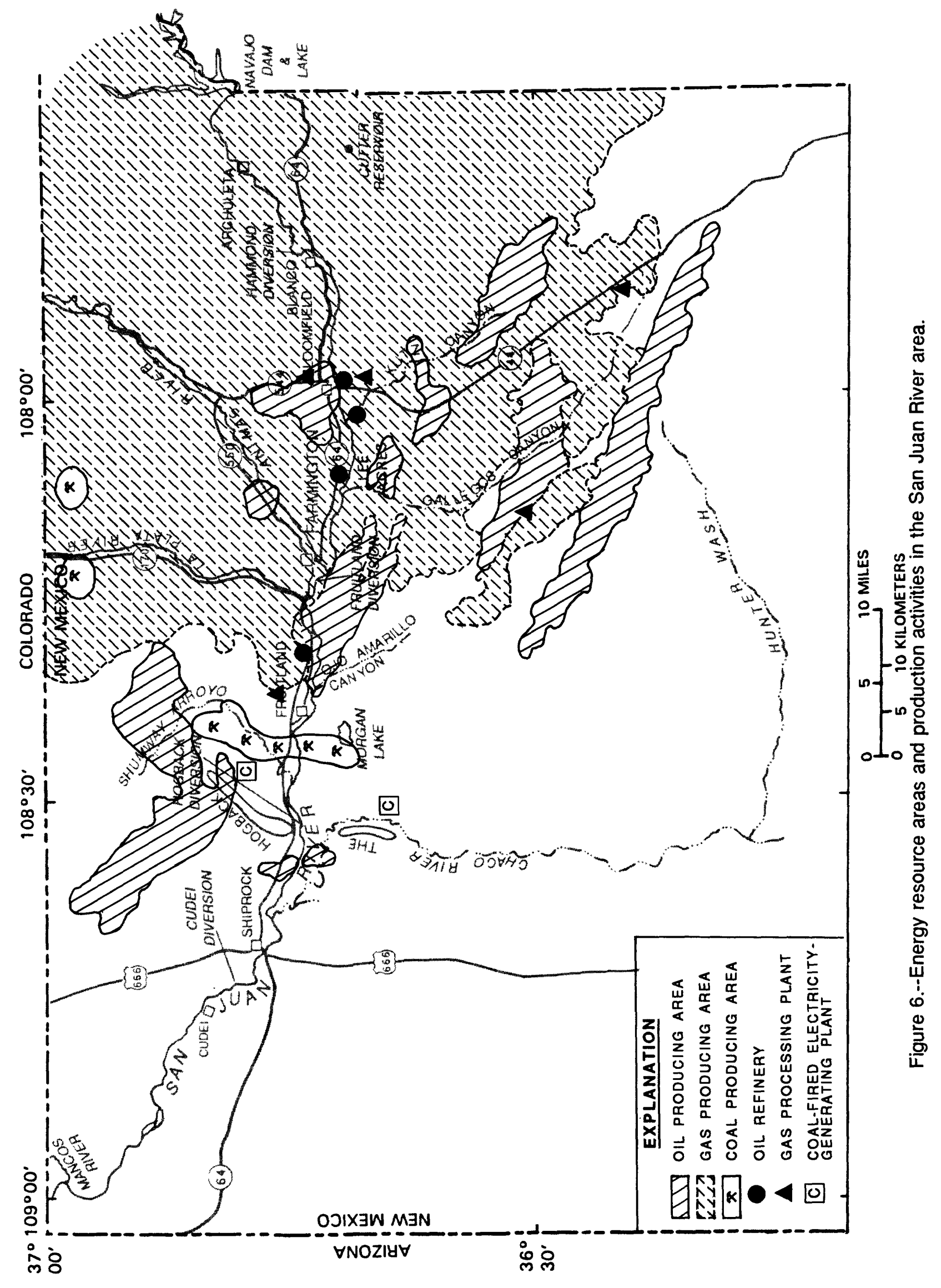




\section{Sampling Sites}

The irrigation project sampling network ("I" sites) was designed so that the number of sites on irrigation projects was approximately proportionate to irrigation project size (fig. 7; table 3 ). The following numbers of sites were chosen for each irrigation project: NIIP, 15; Hammond Project, 5; Hogback Project, 3; Fruitland Project, 1; and Cudei Project, 0. No sites were on the Cudei Project because of its comparatively small size; the San Juan River site most downstream, R-11 (fig. 8), was chosen to be downstream from the Cudei Project so that any measurable contributions of constituents by the Cudei Project to the San Juan River would be detected. Sampling sites on irrigation projects included selected ponds, marshes, and wetlands that support wildlife, and selected irrigation drains and canals that flow from irrigation projects into the San Juan River.

The San Juan River sampling network ("R" sites) included sites both upstream (site R-1) and downstream (site R-11) from DOI-sponsored irrigation in the study area; the upstream site ( $R-1)$ serves as a reference site for this study. Other "R" sites were at diversions of river water to DOI-sponsored irrigation projects and to the municipal-supply diversion at Shiprock, and at or near tributary mouths (fig. 8; table 4).

Media sampled at irrigation project sites included water, bottom sediment, aquatic plants, invertebrates, and amphibians or fish. Birds were also sampled at some of these sites. Fish were not collected from sites on the NIIP because they were not available. The analysis matrices for these media are listed in tables 5 and 6.

Media sampled at San Juan River sites included water and bottom sediment. In addition to sampling at specific sites, seven reaches of the San Juan River were sampled for fish. The analysis matrices for these media are listed in tables 5 and 7 .

Water samples analyzed for physical properties, major ions, and trace elements were collected prior to or at the beginning of, during, and after the 1990 irrigation season; those analyzed for triazine and chlorophenoxy acid herbicide compounds were collected in May and June 1990; and those analyzed for organophosphate and carbamate insecticide compounds were collected in August 1990. Bottom-sediment samples were collected after the 1990 irrigation season.

Aquatic plant, invertebrate, amphibian, and fish samples in wetland habitats were collected in summer 1990 during maximum metabolic activity. San Juan River fish samples were collected in spring, prior to the 1990 irrigation season, and in fall, after the 1990 irrigation season. Bird samples were collected in late spring and early summer 1990, during the breeding season. 


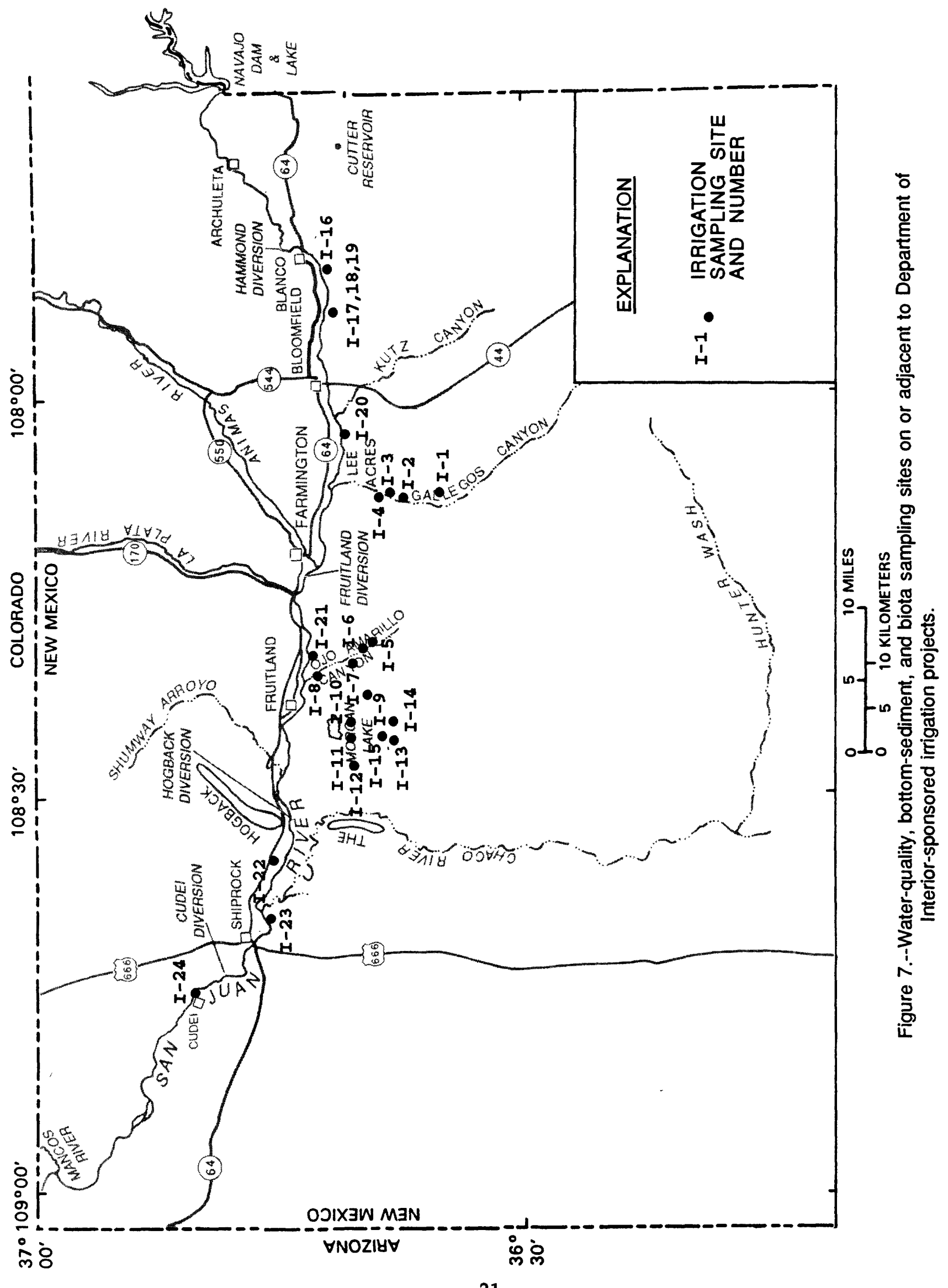


Table 3.--Sampling ("I") sites located on or adjacent to irrigation projects

[Sampling sites shown in fig. 7]

\section{Navajo Indian Irrigation Project}

Gallegos Canyon drainage

I-1 Gallegos Canyon drainage south pond

I-2 Gallegos Canyon drainage middle pond

I-3 Gallegos Ganyon drainage north pond

I-4 Gallegos Canyon 2 miles north of Navajo Highway 3003

ojo Amarillo Canyon drainage

I-5 Ojo Amarillo Canyon three-fourths mile north of Navajo Highway 3003

I-6 0 jo Amarillo Canyon drainage ponds ( 1 mile north of

Nava jo Highway 3003)

I-6A Upstream drainage pond

I-6B Downstream drainage pond

I-7 0jo Amarillo Canyon $21 / 4$ miles north of Navajo Highway 3003

I-8 0jo Amarillo Canyon 4 miles north of Navajo Highway 3003

Ponds in enclosed drainages

I -9 Hidden Pond

I-10 Avocet Pond

I-11 West Avocet Pond

I-12 Northwest Pond-block 3

Chinde Wash drainage

I-13 Chinde Wash drainage southwest pond

I-14 Chinde Wash drainage southeast pond

I-15 Chinde Wash at Navajo Highway 5005

\section{Hammond Project}

East Hammond Project

I-16 East Hammond Project east drain and wetland (about 8 miles east of New Mexico Highway 44)

I-17 East Hammond Project west drain and wetland (about 3 1/2 miles east of New Mexico Highway 44)

I-18 East Hammond Project pond one-tenth mile north of West Drain (Red Pond)

I-19 East Hammond Project pond four-tenths mile northwest of West Drain (adjacent to oil production facility)

West Hammond Project

I-20 West Hammond Project pond (about 2 1/2 miles west of New Mexico Highway 44) 
Table 3.--Sampling ("I") sites located on or adjacent to irrigation projects--Concluded

\section{Fruitland Project}

I-21 Fruitland Project site

Hogback Project

I-22 Hogback Project east drain (about $23 / 4$ miles west of

The Hogback)
I-22B West tributary to Hogback Project east drain

I-23 Hogback marsh (about 1 1/2 miles southeast of Shiprock)

I-24 Hogback Project west drain (about 3 miles northwest of Shiprock) 


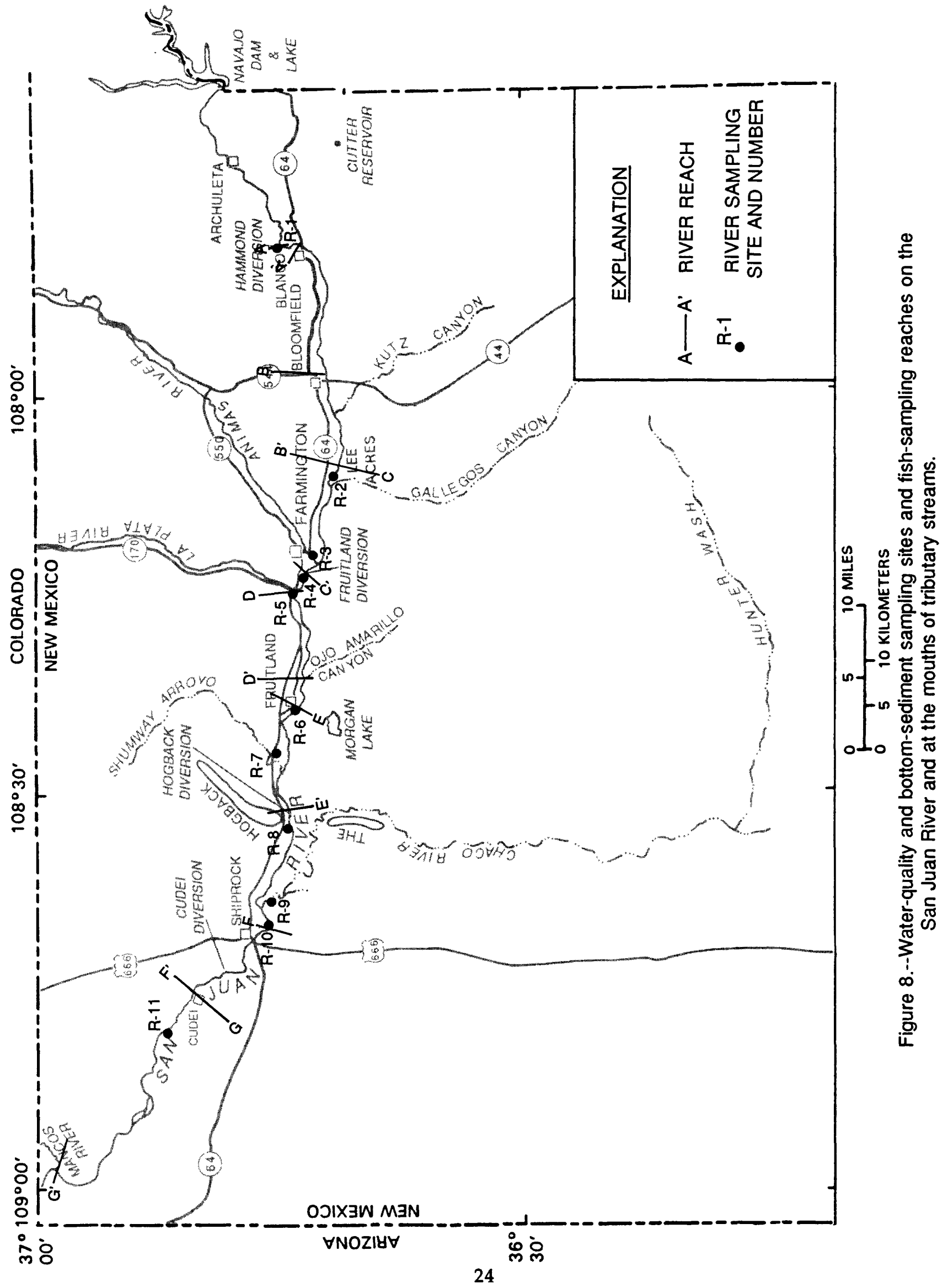


Table 4.--San Juan River reaches from which fish samples were collected, and water and bottom-sediment sampling ("R") sites within each river reach

[River reaches and sampling sites shown in fig. 8]

Reach A Hammond Diversion to Blanco

R-1 San Juan River at Hammond Project Diversion (reference site; upstream from Department of Interior-sponsored irrigation)

Reach B Bloomfield to Lee Acres

Reach C Lee Acres to Farmington

R-2 San Juan River 1 mile upstream from mouth of Gallegos Canyon

R-3 Animas River at mouth

R-4 Fruitland Project Diversion ${ }^{1}$

Reach D La Plata River to Ojo Amarillo Canyon

R-5 La Plata River at mouth

Reach E Fruitland to Hogback

R-6 San Juan River one-half mile downstream from Fruitland Bridge

R-7 Shumway Arroyo

R-8 Hogback Project Diversion 1

R-9 Chaco River one-half mile upstream from mouth ${ }^{1}$

R-10 San Juan River at Shiprock Municipal Diversion ${ }^{1}$

Reach F Shiprock to Cudei

Reach G Cudei to Mancos River

R-11 San Juan River 3 miles downstream from Cudei (downstream from Department of Interior-sponsored irrigation)

1Water and bottom-sediment sampling site is outside of river reaches from which fish samples were collected. 
Table 5.--Number of samples and types of analyses for media at sampling sites on irrigation projects, the San Juan River, and tributaries

[Site: see tables 3 and 4 and figs. 7 and 8 for names and locations.

$I$, analysis for inorganic constituents; 0 , analysis for organic pesticides; A, killifish, mosquitofish, fathead minnow; B, common carp, flannelmouthed sucker. Numbers in table are number of samples collected]

Irrigation project sites

I -1

$\mathrm{I}-2$

$I-3$

I -4

I -5

I $-6 A$

I - 6B

I -7

I - 8

I -9

I - 10

I -11

I -12

$\mathrm{I}-13$

I - 14

I -15

I -16

I -17

I -18

I - 20

I -21

I - 22

I - 22B

I -23

I -24

$\begin{array}{llll}3 & 2 & 1 & 1 \\ 3 & 2 & 1 & 1 \\ 3 & 1 & 1 & 0 \\ 3 & 2 & 1 & 0 \\ 0 & 0 & 0 & 0\end{array}$

$\begin{array}{llll}0 & 0 & 1 & 0 \\ 3 & 1 & 0 & 0 \\ 1 & 1 & 1 & 1 \\ 2 & 1 & 0 & 0 \\ 0 & 0 & 0 & 0\end{array}$

$\begin{array}{ll}3 & 1 \\ 1 & 0 \\ 1 & 1 \\ 3 & 2 \\ 1 & 0\end{array}$

$\begin{array}{ll}0 & 0 \\ 0 & 0 \\ 0 & 0 \\ 0 & 0 \\ 0 & 0\end{array}$

$\begin{array}{llll}1 & 0 & 0 & 0 \\ 0 & 0 & 0 & 0 \\ 3 & 0 & 1 & 1 \\ 1 & 0 & 0 & 0 \\ 3 & 0 & 1 & 1\end{array}$

$\begin{array}{ll}3 & 0 \\ 4 & 0 \\ 1 & 0 \\ 3 & 0 \\ 3 & 0\end{array}$

$\begin{array}{ll}1 & 1 \\ 1 & 1 \\ 0 & 0 \\ 1 & 1 \\ 1 & 1\end{array}$

$\begin{array}{ll}1 & 1 \\ 1 & 1 \\ 1 & 1 \\ 0 & 0 \\ 0 & 0\end{array}$

1

1

0

0

1

1

1

1

0

0

1

0

1
1

Medium

$\begin{array}{ccl}\text { Inverte- } & \text { Amphib- } & \\ \text { brates } & \text { ians } & \text { Fish } \\ \text { I } & \text { I } & \text { A B }\end{array}$


Table 5.--Number of samples and types of analyses for media at sampling sites on irrigation projects, the San Juan River, and tributaries--Concluded

\begin{tabular}{|c|c|c|c|c|c|c|c|c|c|}
\hline \multirow[b]{3}{*}{ Site } & \multicolumn{9}{|c|}{ Medium } \\
\hline & \multicolumn{2}{|c|}{ Water } & \multicolumn{2}{|c|}{$\begin{array}{l}\text { Bottom } \\
\text { sediment }\end{array}$} & \multirow{2}{*}{$\begin{array}{c}\text { Aquatic } \\
\text { plants } \\
\text { I }\end{array}$} & \multirow{2}{*}{$\begin{array}{c}\text { Inverte- } \\
\text { brates } \\
\text { I }\end{array}$} & \multirow{2}{*}{$\begin{array}{l}\text { Amphib- } \\
\text { ians } \\
\text { I }\end{array}$} & \multicolumn{2}{|c|}{ Fish } \\
\hline & $\mathrm{I}$ & 0 & $\mathrm{I}$ & 0 & & & & A & B \\
\hline & \multicolumn{4}{|c|}{ San Juan River and } & tributar & ry sites & & & \\
\hline $\mathrm{R}-1$ & 3 & 0 & 1 & 0 & 0 & 0 & 0 & 0 & 0 \\
\hline $\mathrm{R}-2$ & 3 & 0 & 1 & 0 & 0 & 0 & 0 & 0 & 0 \\
\hline$R-3$ & 3 & 0 & 0 & 0 & 0 & 0 & 0 & 0 & 0 \\
\hline$R-4$ & 2 & 0 & 0 & 0 & 0 & 0 & 0 & 0 & 0 \\
\hline$R-5$ & 3 & 0 & 1 & 0 & 0 & 0 & 0 & 0 & 0 \\
\hline$R-6$ & 3 & 0 & 1 & 0 & 0 & 0 & 0 & 0 & 0 \\
\hline$R-7$ & 2 & 0 & 0 & 0 & 0 & 0 & 0 & 0 & 0 \\
\hline$R-8$ & 2 & 0 & 0 & 0 & 0 & 0 & 0 & 0 & 0 \\
\hline $\mathrm{R}-9$ & 3 & 0 & 1 & 0 & 0 & 0 & 0 & 0 & 0 \\
\hline$R-10$ & 3 & 0 & 0 & 0 & 0 & 0 & 0 & 0 & 0 \\
\hline $\mathrm{R}-11$ & 3 & 0 & 1 & 0 & 0 & 0 & 0 & 0 & 0 \\
\hline
\end{tabular}


Table 6.--Number of bird samples collected for analysis of inorganic constituents at sites on irrigation projects

[Site: see table 3 and fig. 7 for names and locations]

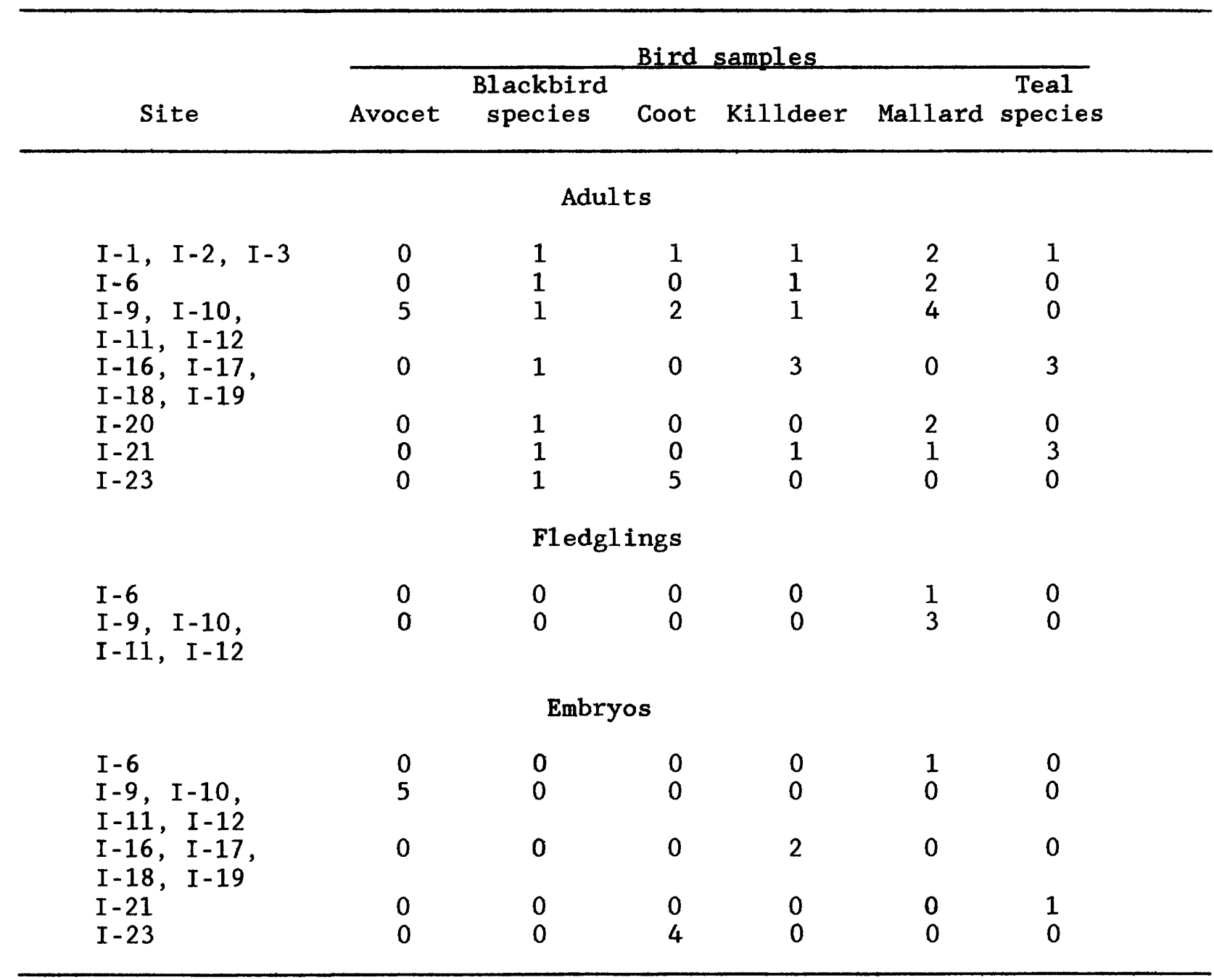


Table 7.--Types of analyses conducted on fish samples from reaches of the San Juan River

[S, spring sampling period; F, fall sampling period; I, analysis for inorganic constituents; 0 , analysis for organochlorine pesticides;

river reach: see fig. 8 for location]

\begin{tabular}{|c|c|c|c|c|c|c|c|c|c|}
\hline \multicolumn{2}{|r|}{ River reach } & \multicolumn{2}{|c|}{$\begin{array}{l}\text { Common } \\
\text { carp }\end{array}$} & \multicolumn{2}{|c|}{$\begin{array}{l}\text { Flannel- } \\
\text { mouthed } \\
\text { sucker }\end{array}$} & \multicolumn{2}{|c|}{$\begin{array}{l}\text { Brown } \\
\text { trout }\end{array}$} & \multicolumn{2}{|c|}{$\begin{array}{l}\text { Channel } \\
\text { catfish }\end{array}$} \\
\hline $\begin{array}{l}\text { A: } \\
\text { B : }\end{array}$ & $\begin{array}{l}\text { Hammond Diversion to Blanco } \\
\text { Bloomfield to Lee Acres }\end{array}$ & I & $\begin{array}{l}\text { I } \\
\text { I }\end{array}$ & $\mathrm{I} / 0$ & $\begin{array}{l}\mathrm{I} \\
\mathrm{I}\end{array}$ & I & I & & \\
\hline $\begin{array}{l}\text { E: } \\
F: \\
\text { G: }\end{array}$ & $\begin{array}{l}\text { Lee Acres to Farmington } \\
\text { La Plata River-to 0jo } \\
\text { Amarillo Canyon } \\
\text { Fruitland to Hogback } \\
\text { Shiprock to Cudei } \\
\text { Cudei to Mancos River }\end{array}$ & $\begin{array}{l}\text { I } \\
\text { I } \\
\text { I } \\
\text { I }\end{array}$ & $\begin{array}{l}\text { I } \\
\text { I } \\
\text { I } \\
\text { I }\end{array}$ & $\begin{array}{l}I / 0 \\
I / 0 \\
I / 0 \\
I / 0\end{array}$ & $\begin{array}{l}\text { I } \\
\text { I } \\
\text { I } \\
\text { I }\end{array}$ & I & & $\begin{array}{l}\text { I } \\
\text { I } \\
\text { I }\end{array}$ & $\begin{array}{l}\text { I } \\
\text { I } \\
\text { I }\end{array}$ \\
\hline
\end{tabular}




\section{Sampling Methods}

Water and bottom-sediment samples were collected according to procedures outlined by U.S. Geological Survey (1982b); Edwards and Glysson (1988); and Severson and others (1988). Biological samples were collected according to procedures outlined by the Fish and Wildlife Service (1985).

Water samples were collected from ponds, marshes, diversions from the San Juan River, and tributaries to the San Juan River, except the Animas River, by submerging a 9-qt churn splitter. Prior to collection of each sample, the churn splitter was thoroughly washed and rinsed with water from the site to be sampled. Equal-width increment, depth-integrated water samples were collected from the San Juan River and the Animas River using a DH-48 sampler. Water samples at these sites were collected at either 5 - or 10 -ft intervals across the entire width of the rivers.

Water temperature, specific conductance, $\mathrm{pH}$, and dissolved oxygen were measured at the time of sample collection and discharge was measured where water was flowing. Samples collected for analysis of anions, trace elements, nitrogen species, and dissolved-uranium concentrations were filtered immediately following sample collection using a peristaltic pump and a $0.45-$ micrometer filter.

Except for mercury, samples collected for analysis of trace-element and uranium concentrations were preserved with a nitric acid solution; samples collected for analysis of mercury concentrations were preserved with a potassium dichromate/nitric acid solution. Samples were preserved immediately following filtration; the $\mathrm{pH}$ of the preserved samples was less than 2.0. Samples collected for analysis of nitrogen species concentrations were preserved with a mercuric chloride/sodium chloride solution and packed in ice immediately following filtration.

Water samples for analysis of pesticides were collected by submerging a 1-liter, baked, brown glass bottle. Prior to sample collection, the bottles were thoroughly rinsed with water from the site to be sampled. Samples were packed in ice immediately following collection.

Al1 bottom-sediment sampling equipment was thoroughly washed with biodegradable detergent powder and water, rinsed with deionized water, and rinsed in water from the site to be sampled immediately prior to sample collection and processing. Composite samples were collected with an unpainted BMH- 53 bottom-sediment sampler. The core barrel of the sampler was stainless steel and the plunger was brass. Nine to 12 equally spaced subsample cores were collected at each site, and the top 3 to 4 in. of each core were combined in a stainless steel bucket and thoroughly mixed with a stainless steel spoon.

Material to be analyzed for trace elements was subsampled and placed in a 500-milliliter polyethylene jar. Sample material to be analyzed for organochlorine compounds was gently worked through a 2-millimeter brass-plated sieve with a stainless steel spoon; material passing through the sieve was retained and placed in a 1-liter, baked, clear glass jar. No water was used during the sieving process. Each sample was packed in ice immediately following sieving. 
Aquatic plants were collected by hand; fauna in wetland habitats were collected by light trap, dipnet, minnow net, and hand seine. Aquatic plant and invertebrate samples were rinsed with deionized water and weighed to the nearest gram. Amphibian samples were weighed to the nearest gram. Fish samples collected in wetland habitats were weighed and measured. All of these samples were sealed in plastic bags and placed on ice in the field, and subsequently frozen the same day as collected.

Fish in the San Juan River were collected by electrofishing. Samples were weighed and measured. Samples collected for trace-element analysis were sealed in plastic bags; those collected for organochlorine analysis were wrapped in aluminum foil. All of these samples were placed on ice in the field, and subsequently frozen the same day as collected.

External Condition Analysis (developed by Dr. John Hickey, U.S. Fish and Wildlife Service, oral and written commun., 1990) was conducted on fish samples. This procedure included observations of external signs of ill health, including lesions and scoliosis (curvature of the spine).

Adult and juvenile bird samples were collected by steel shot; avian eggs were collected by retrieval from nests. Livers and kidneys of adults and juveniles were analyzed for trace elements; carcasses were analyzed for organochlorine compounds. Samples were rinsed with deionized water, weighed to the nearest gram, sealed in plastic bags (1ivers and kidneys) or in aluminum foil (carcasses), placed on ice in the field, and subsequently frozen the same day as collected. Prior to each dissection, equipment was washed in detergent, rinsed with tap water, rinsed three times with deionized water, and air dried.

Bird embryos were analyzed for trace elements. Embryos were removed from the egg, placed in a sterile, acid rinsed jar, weighed to the nearest gram, placed on ice in the field, and frozen the same day as collected.

\section{Analytical Support}

All water samples were analyzed by the U.S. Geological Survey, Water Resources Division National Water Quality Laboratory in Arvada, Colorado. Bottom-sediment samples were analyzed for inorganic constituents by the U.S. Geological Survey, Geologic Division Laboratory in Lakewood, Colorado, and analyzed for pesticides by the U.S. Geological Survey, Water Resources Division National Water Quality Laboratory in Arvada. Samples collected for inorganic constituents were analyzed according to procedures outlined in Fishman and Friedman (1989); samples collected for pesticides were analyzed according to procedures out1ined in Wershaw and others (1987); and samples collected for uranium were analyzed according to procedures outlined in Thatcher and others (1977). Laboratory quality control and quality assurance procedures were those described in Friedman and Erdmann (1982). Laboratory reporting levels for selected constituents are 1 isted in table 8 . 
Table 8.--Laboratory reporting levels for selected constituents in water and bottom sediment

$[\mu \mathrm{g} / \mathrm{L}$, micrograms per 1iter; $\mu \mathrm{g} / \mathrm{g}$, micrograms per gram; $\mu \mathrm{g} / \mathrm{kg}$, micrograms per kilogram]

\begin{tabular}{|c|c|c|c|}
\hline \multicolumn{4}{|c|}{ Analytical reporting limit } \\
\hline Constituent & $\begin{array}{l}\text { Water } \\
(\mu \mathrm{g} / \mathrm{L})\end{array}$ & $\begin{array}{c}\text { Bottom sediment } \\
(\mu \mathrm{g} / \mathrm{g})\end{array}$ & $\begin{array}{c}\text { Bottom sediment } \\
(\mu \mathrm{g} / \mathrm{kg})\end{array}$ \\
\hline \multicolumn{4}{|c|}{ Inorganic constituents } \\
\hline $\begin{array}{l}\text { Arsenic } \\
\text { Boron } \\
\text { Cadmium } \\
\text { Chromium } \\
\text { Copper } \\
\text { Lead } \\
\text { Mercury } \\
\text { Molybdenum } \\
\text { Selenium } \\
\text { Strontium } \\
\text { Uranium } \\
\text { Vanadium } \\
\text { Zinc }\end{array}$ & $\begin{array}{l}1 \\
10 \\
1.0 \\
1 \\
1 \\
1 \\
0.1 \\
1 \\
1 \\
1.0 \\
1 \\
10\end{array}$ & $\begin{array}{l}0.1 \\
0.4 \\
2 \\
1.0 \\
1.0 \\
4.0 \\
0.02 \\
2 \\
0.1 \\
2.0 \\
0.1 \\
2.0 \\
2.0\end{array}$ & \\
\hline \multicolumn{4}{|c|}{ Organic constituents } \\
\hline $\begin{array}{l}\text { Triazine herbicides } \\
\text { Chlorophenoxy acid herbicides } \\
\text { Carbamate insecticides } \\
\text { Organophosphate insecticides } \\
\text { Organochlorine insecticides: }\end{array}$ & $\begin{array}{l}0.1 \\
0.1 \\
0.05 \\
0.01\end{array}$ & & \\
\hline $\begin{array}{l}\text { Toxaphene } \\
\text { Chlordane } \\
\text { PCB's } \\
\text { PCN's } \\
\text { Perthane } \\
\text { All other compounds }\end{array}$ & & & $\begin{array}{r}10 \\
1 \\
1 \\
1 \\
1 \\
0.1\end{array}$ \\
\hline
\end{tabular}


Biological samples were analyzed by laboratories under contract to the U.S. Fish and Wildlife Service, Patuxent Analytical Control Facility, Patuxent, Maryland. Analyses were conducted according to procedures outlined by the U.S. Fish and Wildlife Service (1990). The types of analyses and the laboratory conducting each are: inorganic constituents, Research Triangle Institute, Research Triangle Park, North Carolina; organochlorine compounds, Mississippi State Chemical Laboratory, Mississippi State University, Starkville, Mississippi; and cholinesterase enzyme assays, U.S. Fish and Wildlife Service, Patuxent Wildlife Research Center, Patuxent, Maryland. Arsenic, lead, and selenium were analyzed by graphite furnace atomic absorption, mercury was analyzed by cold vapor atomic absorption, and 18 other constituents were analyzed by inductively coupled plasma spectroscopy.

About 10 percent of water and bottom-sediment samples that were submitted were quality assurance/quality control samples. These samples consisted of split, duplicate, and blank samples. Results of the analyses of these samples are included in tables. 20 through 22 (tables 20-30 are in the Supplemental data section in the back of the report.) All results of analysis of biological samples were subjected to quality assurance/quality control procedures by the U.S. Fish and Wildlife Service, Patuxent Analytical Control Facility, Patuxent, Maryland.

\section{DISCUSSION OF RESULTS}

Seventy-eight water samples were collected and analyzed during three sampling periods: prior to or at the beginning of the irrigation season in April 1990, during the irrigation season generally in August 1990, and following the irrigation season in November and December 1990. Results of these analyses are shown in tables 20 and 21 .

\section{Concentrations of Trace Elements in Water}

Concentrations of dissolved constituents in water were compared to National Baseline Values for rivers in the United States. Data from which these baseline values were calculated are from two National monitoring programs: the National Stream-Quality Accounting Network (NASQAN) and the National Water-Quality Surveillance System (NWQSS). Data have been collected for NASQAN and NWQSS since 1973. Baseline values were calculated by determining the arithmetic mean concentration for a given water-quality property or constituent at each station for which information was available, and then ranking these mean values for all the stations; percentile values were then determined. These percentile values and median and maximum concentrations of trace elements in samples collected for the San Juan River study are shown in table 9 . 
Table 9.--Comparison of baseline concentrations of selected constituents in samples collected from rivers of the United States with concentrations in 28 samples from the San Juan River, diversions, and tributaries, and in 48 samples from irrigation project sites

[Base1ine percentiles: determined from data in National StreamQuality Accounting Network and National Water-Quality Surveillance System data bases. <, less than]

\begin{tabular}{|c|c|c|c|c|c|c|c|}
\hline \multirow{3}{*}{$\begin{array}{l}\text { Trace } \\
\text { element }\end{array}$} & \multicolumn{7}{|c|}{$\begin{array}{c}\text { Concentration } \\
\text { (micrograms per liter) }\end{array}$} \\
\hline & \multicolumn{3}{|c|}{$\begin{array}{c}\text { Baseline } \\
\text { percentiles } \\
\end{array}$} & \multicolumn{2}{|c|}{$\begin{array}{l}\text { San Juan River, } \\
\text { diversions, and } \\
\text { tributaries } \\
\end{array}$} & \multicolumn{2}{|c|}{$\begin{array}{c}\text { Irrigation } \\
\text { project } \\
\text { sites }\end{array}$} \\
\hline & 25 & 50 & 75 & Median & Maximum & Median & Maximum \\
\hline Arsenic & $<1$ & 1 & 3 & 1 & 1 & 1 & 48 \\
\hline Cadmium & $<2$ & $<2$ & $<2$ & $<1$ & 1 & $<1$ & 2 \\
\hline Chromium & 9 & 10 & 10 & $<1$ & 3 & $<1$ & 2 \\
\hline Lead & 3 & 4 & 6 & $<1$ & 1 & $<1$ & 12 \\
\hline Mercury & 0.2 & 0.2 & 0.2 & $<0.1$ & 0.2 & $<0.1$ & 0.2 \\
\hline Nitrate & 0.2 & 0.41 & 0.89 & 0.2 & 6.3 & 0.2 & 19 \\
\hline Selenium & $<1$ & $<1$ & $<1$ & $<1$ & 4 & 2 & 67 \\
\hline Zinc & 12 & 15 & 21 & 7 & 13 & $<10$ & 20 \\
\hline
\end{tabular}

For samples collected from the San Juan River, diversions, and tributaries (the Animas, La Plata, and Chaco Rivers), the median concentration of each trace element except arsenic was equal to or less than the 25thpercentile baseline concentration. For samples collected from irrigation project sites, the median concentration of each trace element except arsenic and selenium was equal to or less than the $25 \mathrm{th}$-percentile baseline concentration. For both groups of samples, the median concentration of arsenic was equal to the 50th-percentile baseline concentration. The median concentration of selenium in water from irrigation sites was $2 \mu \mathrm{g} / \mathrm{L}$, compared with less than $1 \mu \mathrm{g} / \mathrm{L}$ for the $25 \mathrm{th}-$, 50th-, and $75 \mathrm{th}-$ percentile baseline concentrations.

If the distribution of concentrations of a given constituent in the San Juan River area data set were the same as in the data set from which the baseline values were calculated, then the number of samples expected to be larger than the 75 th-percentile baseline concentration would be 7 in the group collected from the San Juan River, diversions, and tributaries (28 samples), and 12 in the group collected from irrigation project sites (48 samples). Except for selenium, the number of samples exceeding the $75 \mathrm{th}$-percentile concentration was less than the expected number for all trace elements in both groups. Selenium concentrations were larger than the baseline 75th-percentile concentration in 28 of 48 samples from irrigation project sites (table 21).

To further evaluate water-quality conditions in the study area, concentrations of selected constituents were compared to applicable USEPA Primary Drinking-Water Standards and with State of New Mexico standards for several water uses (U.S. Environmental Protection Agency, 1986a, 1986b; New Mexico Water Quality Control Commission, 1988). These Federal and State standards for selected constituents are 1isted in table 10. 
Table 10.--U.S. Environmental Protection Agency and State of New Mexico water-quality standards for selected constituents

[USEPA: U.S. Environmental Protection Agency; USEPA drinking-water standard: Federally enforceable Primary Drinking-Water Standard Maximum Contaminant Level (U.S. Environmental Protection Agency, 1986a), except as noted; State of New Mexico standard: New Mexico Water Quality Control Commission, 1988. $\mu \mathrm{g} / \mathrm{L}$ : micrograms per liter. - not applicable]

\begin{tabular}{|c|c|c|c|c|c|}
\hline \multirow[b]{2}{*}{ Constituent } & \multirow{2}{*}{$\begin{array}{l}\text { USEPA drink- } \\
\text { ing-water } \\
\text { standard } \\
(\mu \mathrm{g} / \mathrm{L})\end{array}$} & \multicolumn{4}{|c|}{ State of New Mexico standard } \\
\hline & & $\begin{array}{c}\text { Domestic } \\
(\mu \mathrm{g} / \mathrm{L})\end{array}$ & $\begin{array}{l}\text { Irrigation } \\
(\mu \mathrm{g} / \mathrm{L})\end{array}$ & $\begin{array}{l}\text { Livestock/ } \\
\text { wildlife } \\
(\mu \mathrm{g} / \mathrm{L})\end{array}$ & $\begin{array}{c}\text { Fisheries } \\
(\mu \mathrm{g} / \mathrm{L})\end{array}$ \\
\hline Arsenic & 50 & 50 & 100 & 200 & -- \\
\hline Boron & -- & -- & 750 & 5,000 & - \\
\hline Cadmium & 10 & 10 & 10 & 50 & 11.1 \\
\hline Chromium & 100 & 50 & 100 & 1,000 & 1210 \\
\hline Copper & 21,000 & - & 200 & 500 & 112 \\
\hline Lead & 50 & 50 & 5,000 & 100 & 13.2 \\
\hline Mercury & 2 & 2 & - - & 10 & 0.012 \\
\hline Nitrate & 10,000 & 10,000 & - & -- & -- \\
\hline Selenium & 350 & 50 & 20 & 50 & 5 \\
\hline Vanadium & - - & - - & 100 & 100 & - - \\
\hline Zinc & 25,000 & -. & 2,000 & 25,000 & 1110 \\
\hline
\end{tabular}

${ }^{1}$ Hardness dependent: 100 milligrams per 1iter hardness used in calculation. 2Federally non-enforceable Secondary Drinking-Water Standard Maximum Contaminant Level (U.S. Environmental Protection Agency, 1986b).

${ }^{3}$ Federal Register, 1991.

Primary Drinking-Water Standard MCL's established by the USEPA are Federally enforceable water-quality standards. Secondary Drinking-Water Standard MCL's are not Federally enforceable, but establish recommended concentration limits above which aesthetic qualities and public acceptance of drinking water may be adversely affected.

Water-quality standards for several water uses, including domestic water supply, Irrigation, livestock and wildlife watering, and for the protection of fisheries, based on chronic criteria, have been established for streams in New Mexico by the New Mexico Water Quality Control Commission (1988). Within the San Juan River study area, standards for protection of fisheries are applicable to the San Juan, Animas, and La Plata Rivers and to the mouth of the Chaco River. 
In samples collected from the San Juan River and tributary mouths, the maximum concentration of each trace element was 10 percent or less of the applicable USEPA Drinking-Water Standard MCL. The maximum concentration of each trace element except mercury in samples collected from the San Juan River and tributary mouths also was equal to or less than the applicable state of New Mexico standard for the protection of fisheries. The State of New Mexico standard for mercury is $0.012 \mu \mathrm{g} / \mathrm{L}$, whereas the laboratory reporting level for mercury was $0.1 \mu \mathrm{g} / \mathrm{L}$. Thus, the number of samples with mercury concentrations exceeding this criterion is not known.

Concentrations of selenium in samples collected from the main stem of the San Juan River and from diversions were less than $1 \mu \mathrm{g} / \mathrm{L}$ from the Hammond Project Diversion (site R-1) to and including the San Juan River downstream from Fruitland Bridge (site R-6). At the Shiprock Municipal Diversion (site $\mathrm{R}-10$ ) and at the San Juan River near Cudei (site R-11), however, the maximum concentrations of selenium are 1 and $2 \mu \mathrm{g} / \mathrm{L}$, respectively. The increase in selenium concentrations at and downstream from Shiprock is due to several possible reasons. The Mancos Shale, consisting mostly of marine shale, is at the surface in most of the San Juan River study area west of The Hogback, about $8 \mathrm{mi}$ upstream from the Shiprock Diversion. The larger concentrations of selenium could be the result of natural processes acting on the Mancos Shale, irrigation drainage from the east Hogback Project, or a combination of natural processes and irrigation drainage.

Concentrations of trace elements typically were larger in water samples collected from irrigation project sites than in samples collected from the San Juan River and tributary mouths (table 9). The exceptions were chromium and mercury. Although larger maximum concentrations of trace elements typically occurred at irrigation project sites, selenium was the only trace element for which the maximum concentration was larger (one sample) than the applicable USEPA Primary Drinking-Water Standard MCL (U.S. Environmental Protection Agency, 1986a).

Concentrations of cadmium were larger than the $1.1-\mu \mathrm{g} / \mathrm{L}$ State of New Mexico standard for the protection of fisheries at two sites and the concentration of lead was larger than the $3.2-\mu \mathrm{g} / \mathrm{L}$ standard for the protection of fisheries at one site, but the applicable standard was exceeded in only one of three samples collected at each of these sites. The State of New Mexico water-quality standards for the protection of fisheries are based on chronic criteria; the applicable standards do not appear to be chronically exceeded.

A statistical summary of selenium concentrations in water from irrigation project sites is shown in figure 9. All concentrations of selenium that are far outlying values occurred in three locations: Gallegos Canyon drainage on the NIIP (sites I-2 and I-4), 0jo Amarillo Canyon on the NIIP (sites I-7 and I-8), and the Hogback Project east drain (site I-22). The median concentration of selenium at each location was: I- $2,25 \mu \mathrm{g} / \mathrm{L} ; \mathrm{I}-4,12 \mu \mathrm{g} / \mathrm{L}$; $\mathrm{I}-7 / \mathrm{I}-8,42 \mu \mathrm{g} / \mathrm{L}$; and I-22, $12 \mu \mathrm{g} / \mathrm{L}$. 


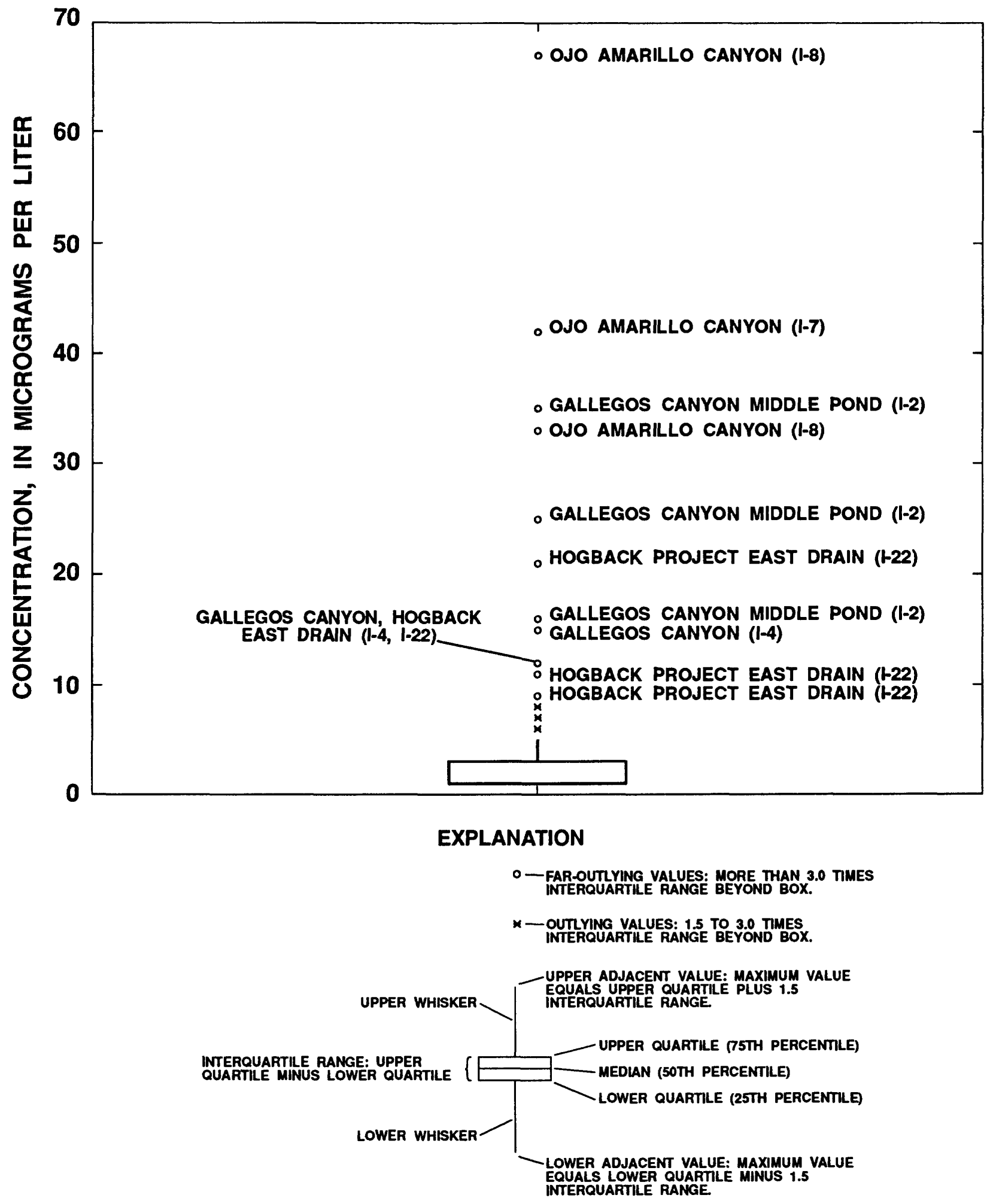

Figure 9.--Concentrations of dissolved selenium in water samples from irrigation project sites. 
The median concentrations of selenium at these sites did not exceed the 50- $\mu \mathrm{g} / \mathrm{L}$ USEPA Primary Drinking-Water Standard MCL but did exceed the 5- $\mathrm{gg} / \mathrm{L}$ State of New Mexico standard for the protection of fisheries. One sample collected at these sites exceeded the USEPA MCL, and all samples exceeded the State of New Mexico standard for protection of fisheries.

Maximum concentrations of selenium in water samples from Gallegos Canyon drainage south pond (site $I-1,7 \mu \mathrm{g} / \mathrm{L}$ ) and the West Hammond Project pond (site $\mathrm{I}-20,6 \mu \mathrm{g} / \mathrm{L}$ ) also exceeded the $5-\mu \mathrm{g} / \mathrm{L}$ State of New Mexico standard for protection of fisheries; however, the median selenium concentration at both sites was $3 \mu \mathrm{g} / \mathrm{L}$. This standard does not appear to be chronically exceeded at these sites.

These data show that in specific geographical areas or at specific locations on irrigation projects, concentrations of dissolved selenium chronically exceeded the State of New Mexico standard for protection of fisheries of $5 \mu \mathrm{g} / \mathrm{L}$ (New Mexico Water Quality Control Commission, 1988). These areas are not included in waters designated by the State of New Mexico as fisheries; however, the concentrations of selenium at these sites do indicate a potential for harmful effects to the aquatic communities that inhabit them, and to wildlife that feed on these aquatic communities.

In summer 1990, water samples from 22 sites throughout the San Juan River area were screened for acute toxicity using photobacteria. of 149 tests conducted on the 22 sites, 22 water samples from 7 sites induced a toxic response in the photobacteria.

The results of the acute-toxicity screening were used to select eight sites for comparative 48-hour acute-toxicity tests using Daphnia magna and captively reared Colorado squawfish larvae from the Dexter National Fish Hatchery in Dexter, New Mexico (outside the study area). The sites selected were the Gallegos Canyon drainage middle pond (I-2), Gallegos Canyon (I-4), ojo Amari1lo Canyon (I-7), block 3 northwest pond (I-12), Chinde Wash drainage southeast pond (I-14), East Hammond Project east drain and wetland (I-16), West Hammond Project pond (I-20), and the Hogback Project east drain (I-22). The acute-toxicity tests were conducted according to the protocols established by the U.S. Environmental Protection Agency (1985).

None of these tests indicated acute toxicity to either Daphnia magna or Colorado squawfish larvae. The maximum concentration of selenium in water samples collected from the test sites was $42 \mu \mathrm{g} / \mathrm{L}$ from 0 jo Amarillo Canyon (site I-7). Kemp and others (1973) established a concentration of selenium of $50,000 \mu \mathrm{g} / \mathrm{L}$ to be lethal to 50 percent of a test population of Colorado squawfish over a 96-hour period: 96-hour $\mathrm{LC} / 50=50,000 \mu \mathrm{g} / \mathrm{L} \quad$ (LC = lethal concentration). Therefore, at concentrations of selenium in the San Juan River area, toxicity to aquatic species would be chronic rather than acute. 


\section{Concentrations of Trace Elements in Bottom Sediment}

Bottom-sediment samples were collected from four sites on the San Juan River; from the mouths of two tributaries; from six sites on the NIIP; from one site each on the East Hammond, West Hammond, and Fruitland Projects; and from three sites on the Hogback Project for a total of 18 samples. One replicate and one split sample were analyzed for quality assurance. These samples were from the south pond in Gallegos Canyon (site I-1) and from 0jo Amarillo Canyon (site I-7).

Two size fractions of bottom sediment were analyzed for each of the 18 samples: the fraction less than 0.062 millimeter; and the fraction less than 2 millimeters, which includes the fraction less than 0.062 millimeter. The fraction less than 0.062 millimeter was used for the following interpretation because the median concentrations of arsenic, cadmium, chromium, copper, lead, molybdenum, selenium, strontium, vanadium, and zinc in the fraction less than 0.062 millimeter were equal to or larger than the median concentrations of these trace elements in the fraction less than 2 millimeters. The results of analysis of both size fractions of these samples are listed in table 22 .

Concentrations of selected constituents were compared to values in soils of the United States west of the $97 \mathrm{th}$ parallel (Shacklette and Boerngen, 1984), to values (except selenium) in 47 soil samples collected in the San Juan Basin, New Mexico (Severson and Gough, 1981), and to concentrations measured as part of 19 studies of the National Irrigation Water-Quality Program (NIWQP) (Severson and others, 1991). Six of Severson's and Gough's (1981) 47 sites were within the San Juan River study area. The 95-percent expected-value ranges of concentrations (the concentrations within which 95 percent of the results of analyses are expected to be included) and the geometric mean concentrations of selected trace elements determined in soils of the Western United States and soil samples from the San Juan Basin are listed in table 11. The range of concentrations in the fractions less than 0.062 millimeter and less than 2 millimeters of samples collected as part of the NIWQP, and the range of concentrations and the median concentrations of the less-than-0.062-millimeter fraction of samples from the San Juan River area also are listed in table 11 .

Two different indicators of the central value for concentrations of trace elements were used. The geometric mean was used by Severson and Gough (1981) and by Shacklette and Boerngen (1984). In the San Juan River study, the median value of concentrations was used.

Concentrations of 22 of 198 individual analyses for trace elements (18 samples analyzed for the 11 trace elements listed in table 11 for San Juan Basin soils) in bottom sediment from the San Juan River area were larger than the respective upper expected-value concentration in soils in the San Juan Basin (Severson and Gough, 1981). These included nine strontium, five lead, four chromium, two copper, and two zinc analyses. The largest concentrations of strontium were from the Gallegos Canyon drainage middle and north ponds (sites $I-2$ and $I-3$ ) and the West Hammond Project pond (site I-20); the concentrations of strontium at these three sites were, respectively, about $3.6,2.4$, and 2.2 times the upper expected value of $410 \mu \mathrm{g} / \mathrm{g}$ (tables 11 and 22). The concentration of lead at the Hogback marsh (site I-23) was twice the upper expected value of $22 \mu \mathrm{g} / \mathrm{g}$. None of the other concentrations in the 18 individual samples were more than 1.5 times the respective upper expected value. 


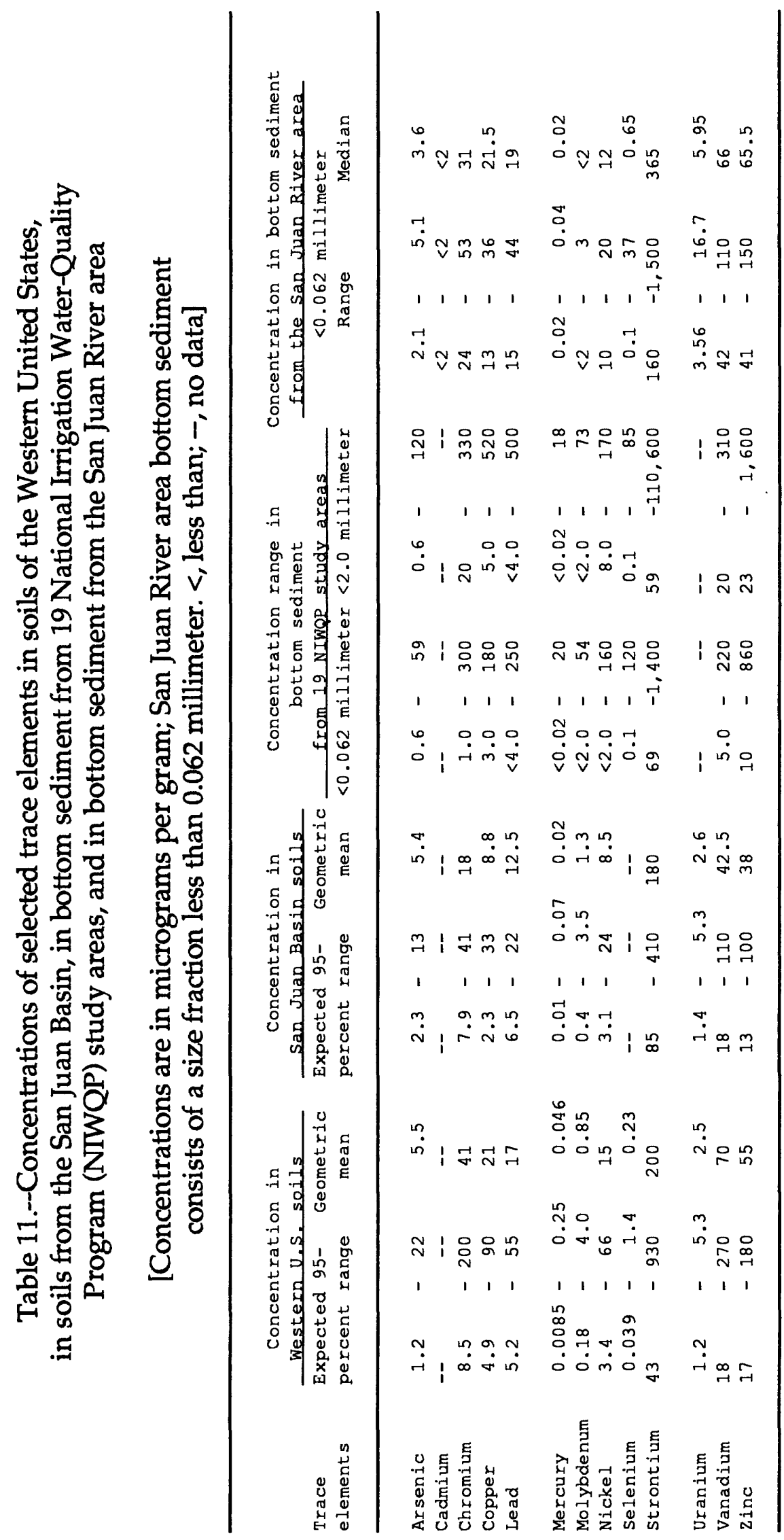


The maximum concentration of selenium in six samples collected from the San Juan River and in two tributary samples collected from the mouths of the La Plata and Chaco Rivers (sites $R-5$ and $R-9$ ) was $0.4 \mu \mathrm{g} / \mathrm{g}$, less than the upper expected value of $1.4 \mu \mathrm{g} / \mathrm{g}$ selenium in soils of the Western United States (Shacklette and Boerngen, 1984). The median concentration of selenium in these six samples was $0.25 \mu \mathrm{g} / \mathrm{g}$, similar to the geometric mean selenium concentration of $0.23 \mu \mathrm{g} / \mathrm{g}$ in soils of the Western United States.

The maximum concentration of selenium in 12 samples collected from sites on irrigation projects was $37 \mu \mathrm{g} / \mathrm{g}$ at the Gallegos Canyon drainage middle pond (site I-2). Eight of these 12 samples had concentrations of selenium larger than the upper expected value of $1.4 \mu \mathrm{g} / \mathrm{g}$ for soils of the Western United States. The bottom-sediment samples having the largest concentrations of selenium, in $\mu \mathrm{g} / \mathrm{g}$, are from the following sites:

\begin{tabular}{llc}
\hline & Site & $\begin{array}{c}\text { Selenium } \\
\text { concentration }\end{array}$ \\
\hline I-2 Gallegos Canyon drainage middle pond & 37 \\
I-22 Hogback Project east drain & 6.0 \\
I-24 Hogback Project west drain & 5.5 \\
I-7 Ojo Amarillo Canyon & 5.0 \\
I-23 Hogback marsh & 4.5 \\
\hline
\end{tabular}

These sites include three of the four locations where selenium concentrations in water exceeded established standards. The concentration of selenium in all other bottom-sediment samples was less than $2 \mu \mathrm{g} / \mathrm{g}$.

Maximum concentrations of other trace elements in the San Juan River area typically were about one order of magnitude smaller than those in the lessthan-0.062-millimeter size fraction from the 19 NIWQP study areas (table 11). Exceptions include mercury and strontium; maximum mercury concentrations were about three orders of magnitude smaller in the San Juan River area than in the 19 NIWQP study areas, and maximum strontium concentrations were about the same as in the 19 NIWQP study areas.

\section{Concentrations of Trace Elements in Biota}

Plants, invertebrates, amphibians, and fish were collected where avallable from pond and wetland areas associated with irrigation. Fish also were collected from several reaches of the San Juan River, and birds were collected throughout the study area. 
Pond and Wetland Community Members

Fifteen plant samples, 15 invertebrate samples, 9 amphibian samples, and 14 fish samples from pond and wetland areas were collected and analyzed. Plant samples consisted of Potamogeton species and Chara species. Invertebrate samples consisted of both single- and mixed-taxa composites of Odonata, Coleoptera, Decapoda, Gastropoda, and Hemiptera. Amphibian samples consisted of the aquatic phase of the tiger salamander (Ambystoma tigrinum), commonly referred to as waterdog, and one tadpole sample (Rana species). Fish samples consisted of mosquitofish (Gambusia affinis), plains killifish (Fundulus zebrinus), fathead minnow (Pimephales promelas), common carp (Cyprinus carpio), and flannelmouthed sucker (Catostomus latipinnis). Results of these analyses are listed in table 23.

Eleven constituents were present in all or nearly all samples at concentrations larger than laboratory reporting levels (table 12). Antimony, beryllium, molybdenum, and tin rarely were present in concentrations larger than laboratory reporting levels in any of the media sampled (table 12). Antimony and berylilium each were present at concentrations at or above these levels in one plant sample, molybdenum was present in five plant samples and two invertebrate samples, and tin was present in four plant samples.

Cadmium, cobalt, nickel, and vanadium rarely were present or were not present at concentrations larger than laboratory reporting levels in amphibians or fish; arsenic rarely was present at concentrations larger than its laboratory reporting level in fish (table 12). Mercury was not present at concentrations larger than its laboratory reporting level in any plant samples but was present in about one-half of the faunal samples.

Toxicity criteria for whole-body concentrations of selenium in fish and in food items consumed by waterfowl and fish have been empirically established. Lemly and Smith (1987) established $12 \mu \mathrm{g} / \mathrm{g}$ dry weight as a whole-body concentration in fish above which reproductive failure may occur. They also established $5 \mu \mathrm{g} / \mathrm{g}$ dry weight in food items as a concentration above which ingestion by fish may result in reproductive failure or mortality. Heinz and others (1989) established a dietary threshold of 4 to $8 \mu \mathrm{g} / \mathrm{g}$ dry weight in food items as a concentration range above which ingestion by waterfowl may impair reproduction. Ranges and medians of dry-weight concentrations of selenium in the various media sampled from pond and wetland communities are listed in table 13.

The maximum concentration of selenium in each medium except plants exceeded food-item criteria concentrations by factors ranging from about 6 to 10 (Lemly and Smith, 1987) for fish and by factors ranging from about 4 to 6 (Heinz and others, 1989) for waterfowl. The sampling sites for which concentrations of selenium in the pond and wetland community members exceeded the various food-item criteria are listed in table 14. 


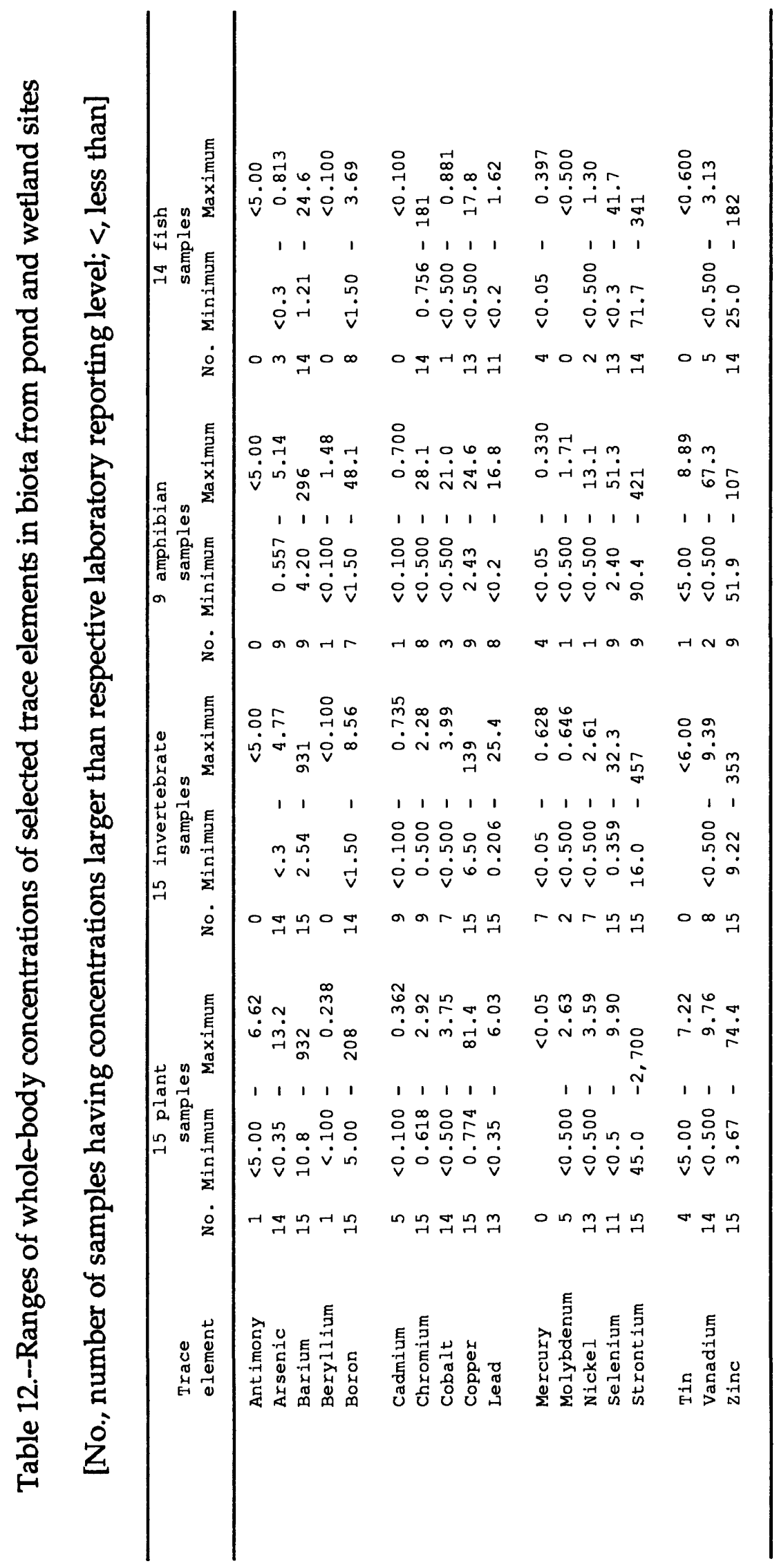


Table 13.--Selenium concentration ranges and medians for pond and wetland community media

$$
[<\text {, less than }]
$$

\begin{tabular}{lccc}
\hline & \multicolumn{3}{c}{ Concentration } \\
\cline { 2 - 4 } Medium & Minimum & Maximum & Median \\
& & & \\
& & 9.90 & 1.16 \\
Plants & 0.5 & 32.3 & 3.12 \\
Invertebrates & .359 & 51.3 & 4.22 \\
Amphibians & 2.40 & 41.7 & 3.77 \\
Fish1 & $<.3$ & 35.1 & 2.32 \\
Fish 2 & 2.00 & & \\
\hline
\end{tabular}

1 Mosquitofish, killifish, and fathead minnow.

${ }^{2}$ Common carp and flannelmouthed sucker. 
Table 14.--Pond and wetland sites in which the concentrations of selenium in biota exceeded food-item criteria

[See fig. 7 for site locations. Selenium concentration in micrograms per gram $(\mu \mathrm{g} / \mathrm{g})$ dry weight. Criteria: 4 to $8 \mu \mathrm{g} / \mathrm{g}$ as a waterfowl

food item (Heinz and others, 1989); $5 \mu \mathrm{g} / \mathrm{g}$ as a fish food item (Lemly and Smith, 1987)]

Site

number
Site name
Selenium

concentration

\section{P1ants (15 samples)}

I-2 Gallegos Canyon drainage middle pond 9.90

I-22 Hogback Project east drain 5.10

Invertebrates (15 samples)

I-2 Gallegos Canyon drainage middle pond 32.3

I-22 Hogback Project east drain 17.4

I-22 Hogback Project east drain 11.1

I-6 0jo Amarillo Canyon drainage ponds 10.2

I-20 West Hammond Project pond 9.62

I-3 Gallegos Canyon drainage north pond $\quad \mathbf{8 . 7 5}$

I-1 Gallegos Canyon drainage south pond $\quad \mathbf{4 . 4 2}$

$$
\text { Amphibians ( } 8 \text { samples) }
$$

I-2 Gallegos Canyon drainage middle pond 51.3

I-3 Gallegos Canyon drainage north pond 23.5

I-6 Ojo Amarillo Canyon drainage ponds 14.7

I-1 Gallegos Canyon drainage south pond 5.24

I-6 0jo Amarillo Canyon drainage ponds $\quad 4.22$

Fish: mosquitofish, killifish, and fathead minnow ( 9 samples)

I -22

Hogback Project east drain

41.7

$\mathrm{I}-22$ Hogback Project east drain

27.2

$I-20$ West Hammond Project pond

15.5

$I-20$

West Hammond Project pond

13.6

Fish: common carp and flannelmouthed sucker (5 samples)

I-22 Hogback Project east drain

35.1

I -22

Hogback Project east drain

28.5 
In summary, all plant and animal samples from the Gallegos Canyon drainage middle pond and the Hogback Project east drain (sites I-2 and I-22) had concentrations of selenium that exceeded the $5-\mu \mathrm{g} / \mathrm{g}$ criterion for fish and that were within or exceeded the 4 - to $8-\mu \mathrm{g} / \mathrm{g}$ criterion for waterfowl. All animal samples from Gallegos Canyon drainage north pond, the 0 jo Amarillo Canyon drainage ponds, and the West Hammond Project pond (sites I-3, I-6, and I-20) had concentrations of selenium that exceeded the $5-\mu \mathrm{g} / \mathrm{g}$ criterion for fish and that were within or exceeded the $4-$ to $8-\mu \mathrm{g} / \mathrm{g}$ criterion for waterfow1. Fish samples from the West Hammond Project pond and the Hogback Project east drain (sites I-20 and I-22) also had concentrations of selenium that exceeded the whole-body $12-\mu \mathrm{g} / \mathrm{g}$ concentration above which reproduction can be impaired. Median concentrations of selenium in water at and near some of these locations (I-2, I-4,I-7, I-8, and I-22) also were 1arger than established standards, and concentrations in bottom sediment (sites I-2, I-7, and I-22) were as large or larger than the upper expected concentration in soils of the Western United States.

A waterdog sample from the Gallegos Canyon drainage south pond (site I-1) had a selenium concentration that exceeded the $5-\mu \mathrm{g} / \mathrm{g}$ criterion for $\mathrm{fish}$, and an invertebrate sample from this site had a selenium concentration within the 4- to $8-\mu \mathrm{g} / \mathrm{g}$ criterion for waterfowl. Approximately 15 percent of mosquitofish collected from the Hogback Project east drain (site I-22) were observed to have scoliosis.

The generally accepted safe maximum concentration of lead in animal food items is $0.3 \mu \mathrm{g} / \mathrm{g}$ wet weight, or approximately $1 \mu \mathrm{g} / \mathrm{g}$ dry weight (Irwin, 1988). In the San Juan River area, 11 of 15 plant samples, 6 of 15 invertebrate samples, 1 of 9 amphibian samples, and 4 of $14 \mathrm{fish}$ samples collected from pond and wetland habitats had concentrations of lead larger than $1 \mu \mathrm{g} / \mathrm{g}$ dry weight (table 23). Plant samples from Avocet Pond and the Chinde Wash drainage southwest pond (sites I-10 and I-13); invertebrate samples from the Chinde Wash drainage southwest pond, the East Hammond Project east drain and wetland, and the Fruitland Project site (sites I-13, I-16, and I-21); and the amphibian sample (tadpole) from the Fruitland Project site (site I-21) had concentrations of lead larger than $3 \mu \mathrm{g} / \mathrm{g}$ dry weight. The median concentrations of lead were: plants, $1.37 \mu \mathrm{g} / \mathrm{g}$; invertebrates, $0.884 \mu \mathrm{g} / \mathrm{g}$; amphibians, $0.296 \mu \mathrm{g} / \mathrm{g}$; and $\mathrm{fish}, 0.440 \mu \mathrm{g} / \mathrm{g}$ dry weight.

The maximum recommended concentration of mercury in predator food items is $0.1 \mu \mathrm{g} / \mathrm{g}$ dry weight (Eisler, 1987). In the San Juan River area, 7 of 15 invertebrate samples, 2 of 9 amphibian samples, and 3 of $14 \mathrm{fish}$ samples collected from wetland habitats had concentrations of mercury larger than $0.1 \mu \mathrm{g} / \mathrm{g}$ dry weight. Invertebrate samples from the block 3 Northwest Pond, the Chinde Wash drainage southwest pond, and the Hogback marsh (sites I-12, I13, and I-23); the amphibian sample from the Chinde Wash southwest pond (site I-13); and fish samples from the Hogback marsh (site I-23) had concentrations of mercury larger than $0.2 \mu \mathrm{g} / \mathrm{g}$ dry weight. Median concentrations in all media were less than the laboratory reporting level of $0.05 \mu \mathrm{g} / \mathrm{g}$. 
Fish in the San Juan River

Composite fish samples were collected for analysis of trace-element concentrations from six reaches of the San Juan River in spring 1990 and from seven reaches in fall 1990. Each composite sample typically consisted of five individuals of a single species. Composite samples of common carp and flannelmouthed sucker were collected from each reach during each sampling period. In addition, three brown trout (Salmo trutta) and six channel catfish (Ictalurus punctatus) composite samples were collected during the two sampling periods from reaches where they were available. The results of the analyses of these samples are listed in table 24.

The results of analysis of common carp samples were compared with those of common carp samples collected for the NCBP from 1981 to 1984; the results of analysis of flannelmouthed sucker samples were compared with those of samples of the sucker family (Catostomidae) collected for the NCBP from 1981 to 1984. Concentrations of trace elements are considered to be elevated if they are larger than the $85 \mathrm{th}$ percentile of the NCBP data set (Schmitt and Brunbaugh, 1990). As part of the NCBP, 81 samples of common carp and 55 samples of seven species of sucker were collected from sites throughout the United States and analyzed for concentrations of seven trace elements: arsenic, cadmium, copper, lead, mercury, selenium, and zinc (Schmitt and Brunbaugh, 1990).

A subset of the NCBP nationwide data set was created that contained results of analysis of 42 common carp samples and 25 sucker species samples collected in the 17 westernmost contiguous states. This subset was created to determine if any marked differences exist between data from the entire United States and data from the Western United States, and if so, to determine which data set is more appropriate to compare with data collected during this study.

The $85 \mathrm{th}$ percentiles for each of seven trace elements of this western subset were calculated and compared with those of the nationwide data set (table 15). For common carp, five of seven 85th-percentile values varied less than 10 percent between the two data sets. In the western subset, the concentration of selenium was higher and the concentration of lead was lower than in the nationwide subset. For sucker species, three of seven $85 \mathrm{th}$ percentile values varied less than 10 percent between the two data sets: copper, lead, and zinc. In the western subset, the concentration of arsenic was higher and the concentrations of cadmium, mercury, and selenium were lower than in the nationwide subset. The larger number of trace elements in sucker species for which the variation between the data sets was more than 10 percent could be due in part to the inclusion of several species of the sucker family, which might have different metabolic characteristics. 
Table 15.--Comparison of concentrations of trace elements in fish samples collected for the National Contaminant Biomonitoring Program (NCBP)

with samples collected from the San Juan River in 1990

[Concentrations are in micrograms per gram wet weight; <, 1ess than]

\begin{tabular}{|c|c|c|c|}
\hline \multirow{3}{*}{$\begin{array}{l}\text { Trace } \\
\text { element }\end{array}$} & \multirow[b]{2}{*}{$\begin{array}{c}\text { NCBP (1990) 85th- } \\
\text { percentile } \\
\text { concentration } \\
\end{array}$} & \multicolumn{2}{|c|}{ San Juan River } \\
\hline & & Concentration & $\begin{array}{l}\text { Number of samples } \\
\text { with concentration } \\
\text { larger than the } \\
\text { NCBP 85th } \\
\text { percentile }\end{array}$ \\
\hline & Nationwide Western & Minimum Maximum Median & Nationwide Western \\
\hline
\end{tabular}

Common carp

$\begin{array}{lrrrrrrr}\text { Arsenic } & 0.15 & 0.14 & 0.07 & 0.10 & 0.09 & 0 & 0 \\ \text { Cadmium } & .14 & .14 & .02 & .17 & .09 & 2 & 2 \\ \text { Copper } & 1.12 & 1.02 & .79 & 1.87 & 1.32 & 11 & 12 \\ \text { Lead } & .30 & .25 & <.06 & 1.69 & .19 & 4 & 4 \\ \text { Mercury } & .11 & .10 & .06 & .19 & .08 & 3 & 3 \\ \text { Selenium } & 1.25 & 1.70 & .61 & 1.56 & .84 & 2 & 0 \\ \text { Zinc } & 73.7 & 68.8 & 15.1 & 90.3 & 66.4 & 3 & 4\end{array}$

Sucker species

\begin{tabular}{lrrrrrrr} 
Arsenic & 0.17 & 0.20 & $<0.09$ & 0.19 & 0.10 & 1 & 0 \\
Cadmium & .05 & .04 & $<.03$ & .45 & .05 & 0 & 2 \\
Copper & 1.01 & .99 & .58 & 1.47 & .79 & 2 & 3 \\
Lead & .22 & .20 & $<.06$ & .90 & .20 & 4 & 5 \\
Mercury & .18 & .13 & .05 & .32 & .13 & 4 & 6 \\
Selenium & .40 & .35 & .45 & 1.06 & .69 & 13 & 13 \\
Zinc & 20.8 & 21.5 & 12.4 & 42.1 & 15.8 & 2 & 2 \\
\hline
\end{tabular}

${ }^{1}$ The total number of samples collected was 13 for both common carp and sucker species.

The maximum and median concentrations of a given trace element in the San Juan River were compared with the $85 \mathrm{th}$-percentile concentrations of the two NCBP data sets to determine if concentrations of that element were elevated in the San Juan River. If the distribution of concentrations of a given trace element from the San Juan River data set (13 samples) is the same as that of either NCBP data set, then the expected number of samples to have concentrations larger than the NCBP 85 th percentile would be about 2:

$$
(1.00-0.85) \times 13=1.95
$$

If the concentrations of more than two samples from the San Juan River data set are larger than the NCBP 85 th-percentile value, then the San Juan River data set is skewed toward a larger-than-expected number of samples having concentrations larger than the NCBP 85 th percentile. The small sample size (13) 1 imits the rigorous use of this criterion; in most cases, however, this criterion approximately supports comparison of median concentrations of trace elements in the San Juan River with 85 th-percentile concentrations in NCBP data (table 15). 
Concentrations of selenium in flannelmouthed sucker are elevated in the San Juan River when compared with selenium concentrations in all species of suckers in the NCBP data set. In all 13 samples, concentrations of selenium were larger than the $85 \mathrm{th}$-percentile concentration of the nationwide and western NCBP data sets (table 15). The median concentration of selenium in flannelmouthed suckers collected from the San Juan River was approximately twice the $85 \mathrm{th}$-percentile concentration of the western NCBP data set (fig. 10). Selenium concentrations in common carp ranged from 0.77 to 1.56 $\mu \mathrm{g} / \mathrm{g}$ wet weight in samples collected during the spring and from 0.61 to 1.35 $\mu \mathrm{g} / \mathrm{g}$ wet weight in samples collected during the fall. The median values of the spring and fall samples were 0.91 and $0.80 \mu \mathrm{g} / \mathrm{g}$ wet weight, respectively. Selenium concentrations in flannelmouthed sucker ranged from 0.47 to $0.80 \mu \mathrm{g} / \mathrm{g}$ wet weight in samples collected in the spring and from 0.45 to $1.06 \mu \mathrm{g} / \mathrm{g}$ wet weight in samples collected from the same sites in the fall. The median values of the spring and fall samples were 0.69 and $0.68 \mu \mathrm{g} / \mathrm{g}$ wet weight, respectively. These small differences in minimum, median, and maximum concentrations between spring and fall data suggest that neither the common carp nor flannelmouthed sucker was exposed to substantially larger concentrations of selenium during the irrigation season.

The largest concentrations of selenium in common carp and flannelmouthed sucker typically occurred in samples from reaches A and B (fig. 8; table 24). Reach $A$ is located upstream from DOI-sponsored irrigation in the study area, and reach $B$ is located along the Hammond Irrigation Project from Bloomfield to just downstream from Lee Acres. Selenium concentrations in these fish decreased in a downstream direction: the smallest concentrations of selenium typically occurred in reaches $D$ and $E$, which are located from downstream from the mouth of the La Plata River to The Hogback (fig. 8). The NIIP and the Fruitland Irrigation Project are adjacent to these reaches on the south side of the San Juan River, and non-DOI-sponsored irrigation projects are adjacent to these reaches on the north side of the river.

Concentrations of copper in common carp are elevated in the San Juan River. Eleven of 13 samples had copper concentrations larger than the 85 thpercentile concentration of the nationwide NCBP data set; 12 samples had copper concentrations larger than the 85 th-percentile concentration of the western NCBP data set (table 15). The median concentration of copper in common carp collected from the San Juan River was larger than the 85thpercentile concentration of both the nationwide and western NCBP data sets (fig. 11).

Concentrations of lead in flannelmouthed sucker are elevated in the San Juan River. Four of 13 samples of flannelmouthed sucker had concentrations of lead larger than the 85 th-percentile concentration of the nationwide NCBP data set (table 15); 5 samples had concentrations of lead larger than the 85 thpercentile concentration of the western NCBP data set. The median concentration of lead in flannelmouthed suckers collected from the San Juan River was about the same as the 85 th-percentile concentration of both the nationwide and western NCBP data sets (fig. 12).

Concentrations of mercury in flannelmouthed sucker also are elevated in the San Juan River. Four of 13 samples had mercury concentrations larger than the 85 th-percentile concentration of the nationwide NCBP data set (table 15); 6 samples had concentrations of mercury larger than the western NCBP data set. The median mercury concentration in flannelmouthed suckers collected from the San Juan River was about the same as the 85th-percentile concentration of the western NCBP data set (fig. 13). 

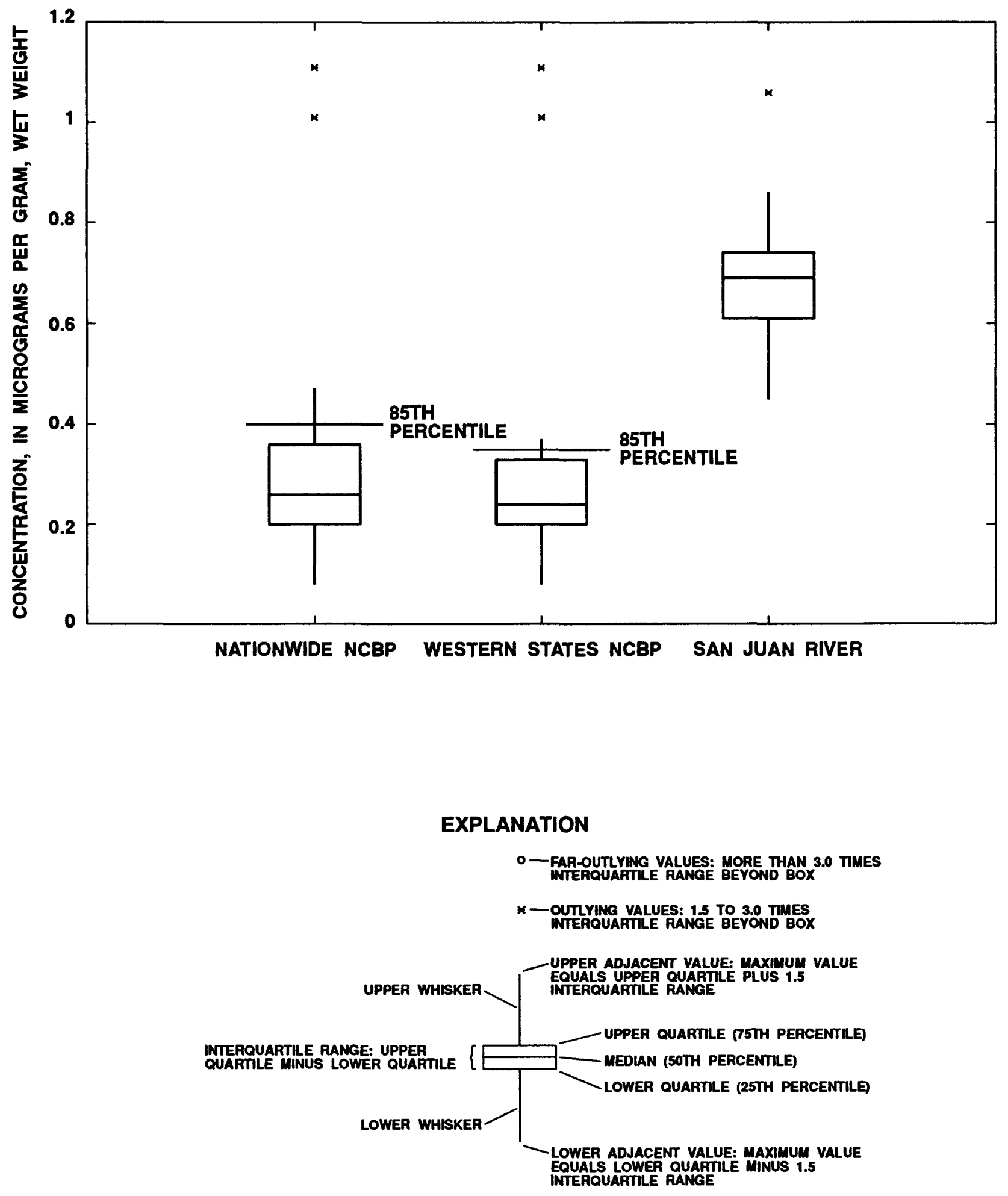

Figure 10.--Distribution of concentrations of selenium in all species of suckers collected for the National Contaminant Biomonitoring Program (NCBP) in 1984, and in flannelmouthed suckers from the San Juan River in 1990. 

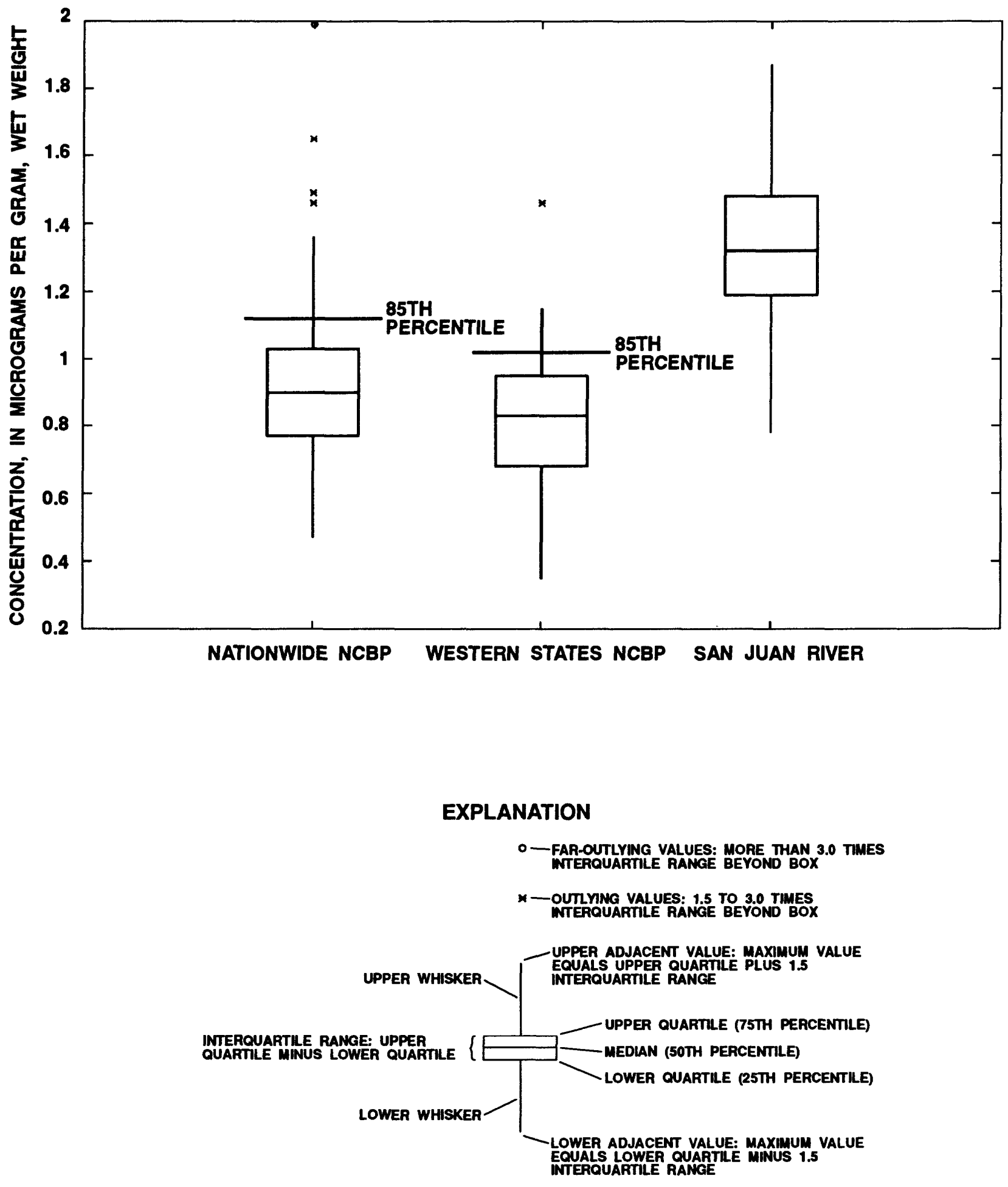

Figure 11.--Distribution of concentrations of copper in carp collected for the National Contaminant Biomonitoring Program (NCBP) in 1984 and from the San Juan River in 1990. 


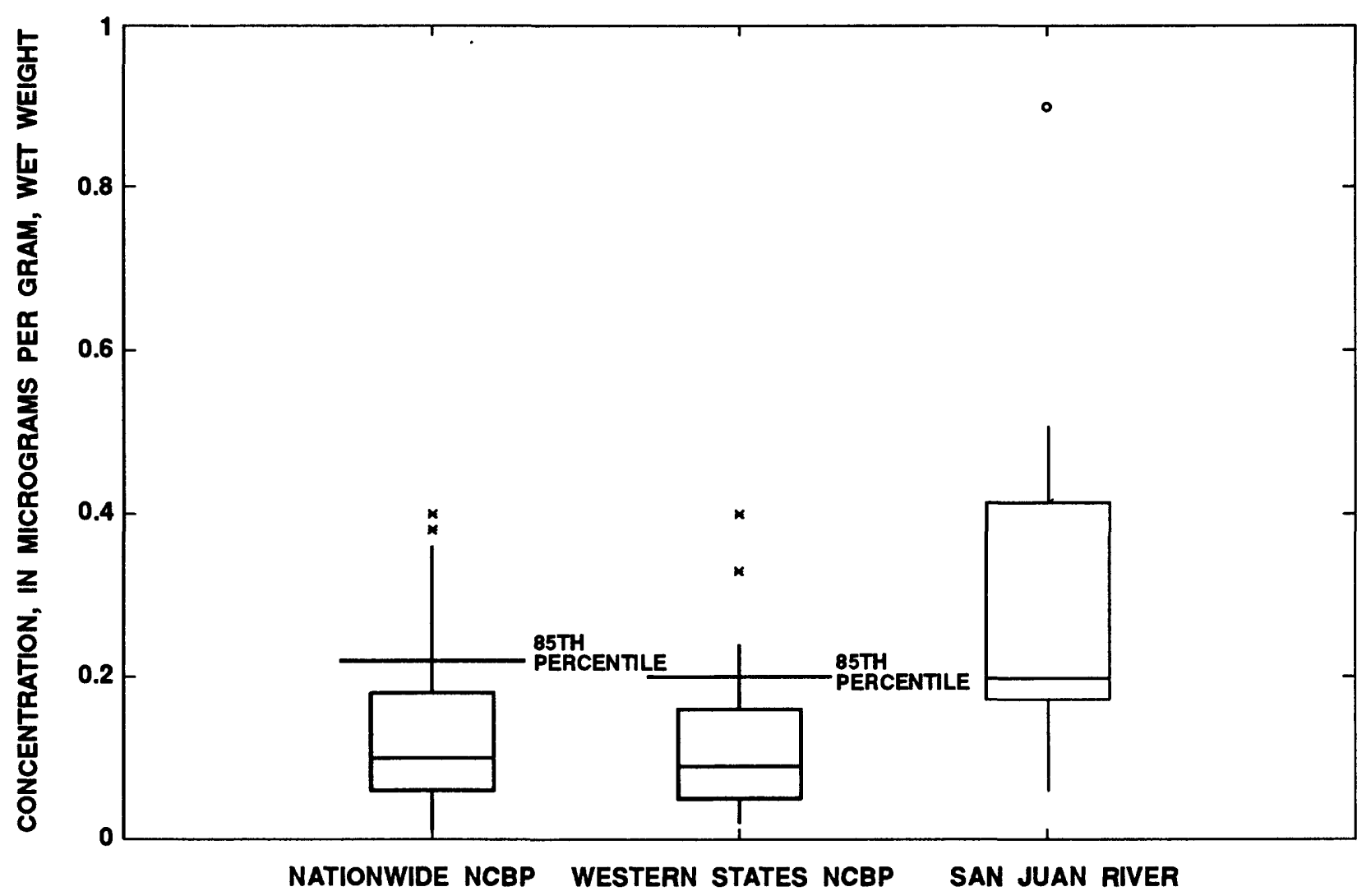

EXPLANATION

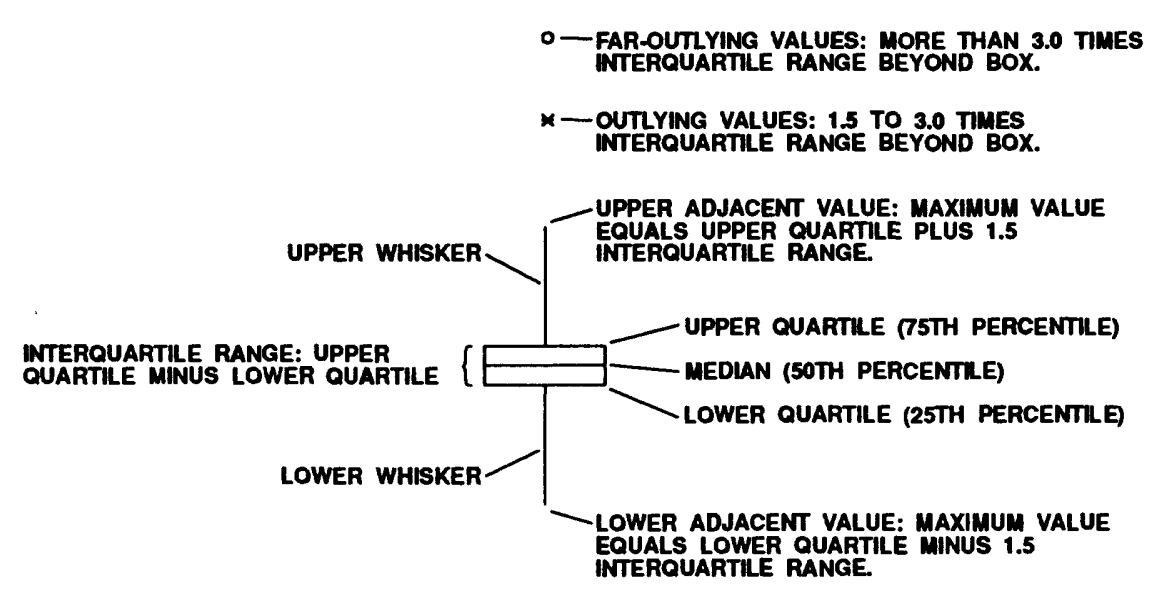

Figure 12.--Distribution of concentrations of lead in all species of suckers collected for the National Contaminant Biomonitoring Program (NCBP) in 1984, and in flannelmouthed suckers from the San Juan River in 1990. 

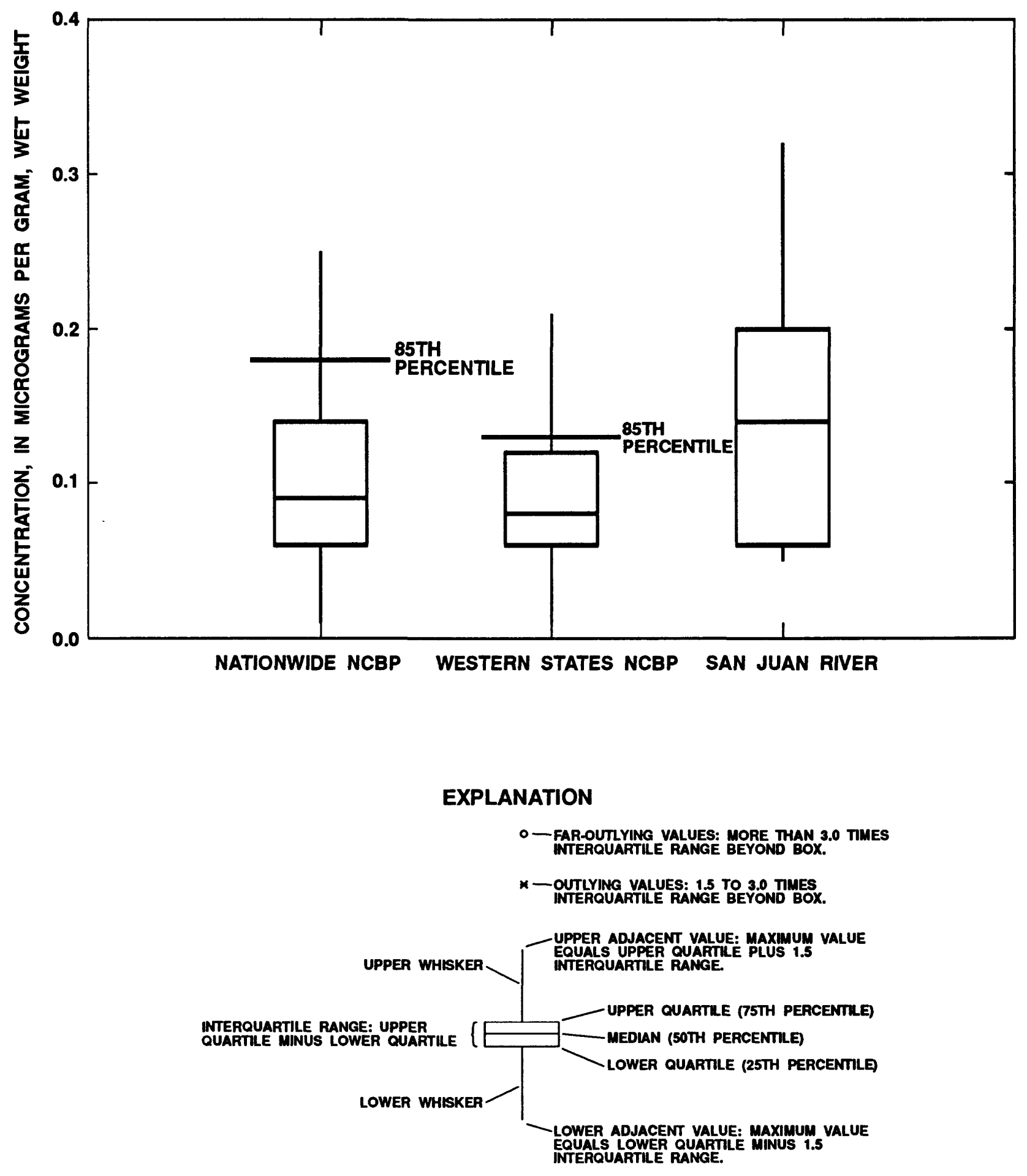

Figure 13.--Distribution of concentrations of mercury in all species of suckers collected for the National Contaminant Biomonitoring Program (NCBP) in 1984, and in flannelmouthed suckers from the San Juan River in 1990. 
Filets of 15 common carp collected in spring 1990, and of 35 common carp, 16 channel catfish, and 5 brown bullhead (Ameiurus nebulosus) collected in fall 1990 were analyzed to determine the concentrations of constituents in the edible portions of these fish. Results of these analyses were distributed to the New Mexico Health Department and New Mexico Environment Department. In October 1991, these agencies jointly issued specific fish consumption guidelines because of mercury contamination in three reaches of the San Juan River from the Hammond Project Diversion to the mouth of the Mancos River (James Piatt, New Mexico Environment Department, written commun., 1992).

The guidelines advised pregnant women to consume no more than one meal per month of common carp up to $24 \mathrm{in}$. in length if caught in any of the three reaches, or consume no more than one meal per month of catfish up to 31 in. if caught between the Hammond Project Diversion and The Hogback, up to 22 in. if caught between The Hogback and Cude1, or up to 29 in. if caught between Cudei and the mouth of the Mancos River. Channel catfish between 31 and 41 in. caught between the Hammond Project Diversion and The Hogback, or between 29 and $37 \mathrm{in}$. caught between Cudei and the mouth of the Mancos River "...should not be eaten by pregnant women, breast-feeding women, women who plan to have children, or anyone under 18 years of age. Everyone else should eat no more than 26 meals of these fish in a year and no more than 13 of the 26 meals should be consumed in 1 month. The remaining meals should be evenly spaced over the remainder of the year."

External conditions were analyzed on all fish sampled during the spring and fall collections except for common carp. Fish were examined for external lesions, including cataracts, melanomas, papillomas, and ulcers.

Twenty-eight percent of flannelmouthed sucker and 35 percent of channel catfish sampled had external lesions. The largest incident rate of lesions in both species was in reach F (Shiprock to Cudei)--50 percent for flannelmouthed sucker and 37 percent for channel catfish. Selenium concentrations in water samples collected from the San Juan River at the Shiprock Municipal Diversion (site R-10) and from the San Juan River $3 \mathrm{mi}$ downstream from Cudei (site R-11) ranged from less than 1 to $2 \mu \mathrm{g} / \mathrm{L}$. The concentration of selenium was $0.3 \mu \mathrm{g} / \mathrm{g}$ in the fraction of the sediment sample less than 0.062 millimeter collected from the San Juan River $3 \mathrm{mi}$ downstream from Cudei (site R-11). These small concentrations in water and bottom sediment, along with larger concentrations of selenium in carp from reach $A$ and larger concentrations of selenium in flannelmouthed sucker from reaches $A$ and $B$, suggest that the incident rate of lesions in reach $F$ is not related to selenium concentrations.

\section{Birds}

Forty-six adult migratory waterbird samples, 4 juvenile mallards, and 13 avian eggs were collected from ponds and wetlands on the four irrigation projects. Species collected include American avocet (Recurvirostra americana), American coot (Fulica americana), mallard (Anas platyrhynchos), cinnamon teal (Anas cyanoptera), green-winged teal (Anas crecca), and killdeer (Charadrius vociferus). Six adult red-winged blackbird samples (Agelaius phoeniceus) and one yellow-headed blackbird sample (Xanthocephalus xanthocephalus) also were collected. 
Composites of liver and kidney tissue from adult and juvenile birds and whole embryos were analyzed for concentrations of trace elements. Liver and kidney were used instead of livers only to maximize sample volume and, at the same time, minimize the number of birds taken. Ohlendorf and others (1990) reported a statistically significant correlation between selenium concentrations in livers and kidneys of adult coots.

Collection sites were grouped by geographical area on the NIIP and the East Hammond Project. On the NIIP, the groups included the Gallegos Canyon drainage ponds (sites $I-1, I-2$, and $I-3$ ) and ponds in enclosed drainages (sites I-9, I-10, I-11, and I-12). On the East Hammond Project, the east and west drains and adjacent wetlands (sites I-16 and I-17) were grouped together. Other waterbird collection sites included the West Hammond Project pond (site I-20), the Fruitland Project site (site I-21), and the Hogback marsh (site I23) (see fig. 7 for site locations). The results of analysis of these samples are 1 isted in table 26 of the Supplemental data section. Statistical summaries of selenium concentrations are shown in figure 14 for species of adult birds and listed in table 16 for adult birds at each site or site group.

Table 16.--Summary of selenium concentrations in adult bird 1iver and kidney tissue at each sampling site or group of sampling sites

[See fig. 7 for site locations]

\begin{tabular}{cccc}
\hline & & \multicolumn{3}{c}{$\begin{array}{c}\text { Concentration of selenium in liver } \\
\text { and kidney tissue, in micrograms } \\
\text { per gram dry weight }\end{array}$} \\
\cline { 3 - 5 } (number of samples) & Minimum & Maximum & Median \\
\hline I-1, I-2, I-3 (6) & 19.7 & 103 & 31.2 \\
I-6 (4) & 14.1 & 31.2 & 20.5 \\
I-9, I-10, I-12 (14) & 2.74 & 22.0 & 12.5 \\
I-16, I-17 (7) & 7.68 & 26.4 & 14.4 \\
I-20 (3) & 3.82 & 25.9 & 4.80 \\
I-21 (6) & 6.49 & 22.7 & 16.2 \\
I-23 (6) & 3.83 & 12.0 & 7.43 \\
\hline
\end{tabular}

Concentrations of selenium varied substantially for a given species at a given site or group of sites. For example, selenium concentrations in two adult mallard samples collected from the West Hammond Project pond (site I-20) were 3.82 and $25.9 \mu \mathrm{g} / \mathrm{g}$, and selenium concentrations in two adult teal samples collected from site I-17 were 7.68 and $26.4 \mu \mathrm{g} / \mathrm{g}$. In samples collected from the enclosed drainages on the NIIP (sites I-9 through I-12), selenium concentrations ranged from 2.84 to $22.0 \mu \mathrm{g} / \mathrm{g}$ in four adult mallard samples and from 5.79 to $21.4 \mu \mathrm{g} / \mathrm{g}$ in three juvenile mallard samples. 


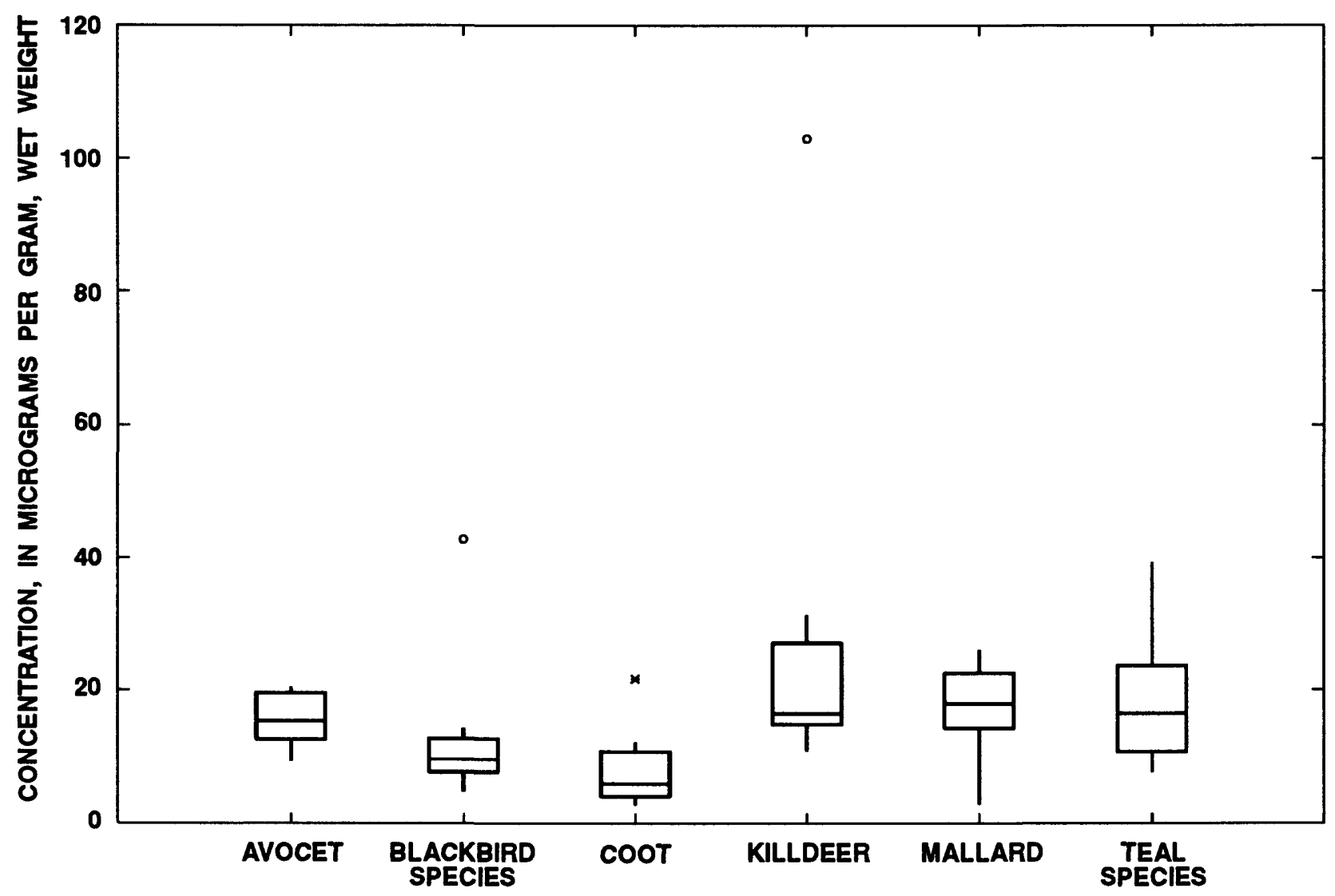

EXPLANATION

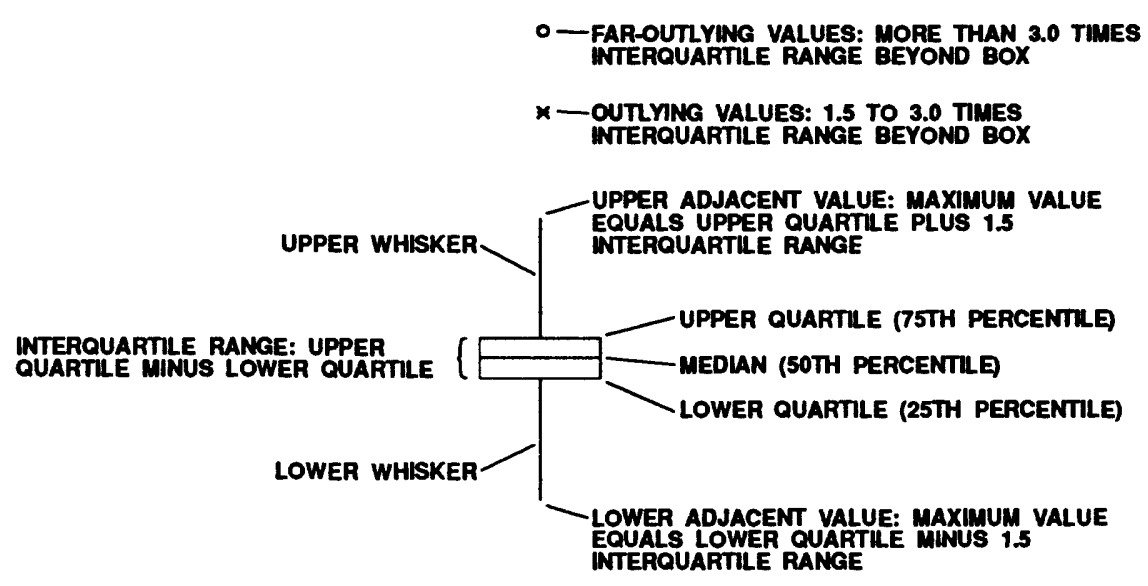

Figure 14.--Concentrations of selenium in adult birds collected from the San Juan River area. 
This variation may be the result of movement of these birds from one wetland habitat to another within the study area or to wetland habitats near but outside the study area. These habitats may have large differences in selenium available in water, sediment, and food items. During this study, adult birds were observed moving from one pond to another in the Gallegos Canyon drainage (sites I-1, I-2, and I-3). Bellrose (1976, p. 229-243) reported that female mallards may move their broods as much as 2 mi to new wetland habitats in response to drought or unstable water conditions, and that adult mallards may use several marshes during courtship and nesting.

Skorupa and others (1990) reported a clear relation between selenium concentrations in livers of adult waterbird populations and the occurrence of deformities in embryos (teratogenesis). Selenium concentrations less than 10 $\mu \mathrm{g} / \mathrm{g}$ dry weight in 1 ivers of adult waterbird populations usually did not cause teratogenesis, whereas those more than $30 \mu \mathrm{g} / \mathrm{g}$ dry weight usually did. Concentrations between 10 and $30 \mu \mathrm{g} / \mathrm{g}$ in livers may or may not have caused teratogenesis. The potential for teratogenesis was species-specific, and observation was required on a case-by-case basis.

The median concentration of $31.2 \mu \mathrm{g} / \mathrm{g}$ selenium in adult bird liver and kidney samples from the Gallegos Canyon drainage ponds (sites I-1, I-2, and I3 ) indicates that teratogenesis can be expected to occur in waterbird populations that inhabit Gallegos Canyon. The median selenium concentration in samples from four other sites or site groups (table 16) indicates that teratogenesis may or may not be occurring, but the potential for teratogenesis exists at these sites. In the entire San Juan River area, median concentrations of selenium in livers and kidneys of 5 avocet samples ( 15.3 $\mu \mathrm{g} / \mathrm{g}), 7$ teal species samples $(16.4 \mu \mathrm{g} / \mathrm{g}), 7$ killdeer samples $(16.4 \mu \mathrm{g} / \mathrm{g})$, and 11 mallard samples $(17.9 \mu \mathrm{g} / \mathrm{g})$ indicate the existing potential for teratogenesis in these species.

One individual and three composite juvenile mallard samples were collected from ponds on the NIIP. One juvenile, collected from the 0 jo Amar1110 Canyon ponds drainage (site I-6), was found dead. The bird was one of two in a composite sample; the concentration of selenium in liver and kidney tissue of this sample was $28.2 \mu \mathrm{g} / \mathrm{g}$. A necropsy did not reveal the cause of death or evidence of physical trauma.

Thirteen avian egg samples were collected from five sites or site groups: one individual mallard sample from the 0 jo Amarillo Canyon drainage ponds (site I-6), three individual and two composite avocet samples from ponds in enclosed drainages on the NIIP (sites I-9, I-10, I-11, and I-12), one individual and one composite killdeer sample from the East Hammond Project east and west drains and adjacent wetlands (sites I-16 and I-17), one composite cinnamon teal sample from the Fruitland Project site (site I-21), and four individual coot samples from a single nest at the Hogback marsh (site I-23). Each composite sample was made up of offspring of the same adult female, and all four individual coot samples collected from the Hogback marsh (site I-23) were offspring of the same adult female. 
No evidence of teratogenesis was observed in bird embryo samples in the San Juan River area; however, only 7 of the 13 samples collected were fully formed and appropriate for inspection. One of these samples was from the 0 jo Amarillo Canyon drainage ponds, and none were from Gallegos Canyon drainage ponds, the West Hammond Project pond, or the Hogback Project east drain, where selenium concentrations in water, bottom sediment, and other biota routinely were larger than established standards and criteria. The embryos examined during this study, therefore, do not accurately reflect conditions throughout the study area.

Skorupa and others (1990), Skorupa and Ohlendorf (1991), and Skorupa and others (U.S. Fish and Wildlife Service, written commun., 1991) reported a clear relation between selenium concentrations in waterbird embryos and the occurrence of teratogenesis. In individual embryos the selenium concentrations less than $9 \mu \mathrm{g} / \mathrm{g}$ dry weight usually did not cause teratogenesis, whereas those more than $60 \mu \mathrm{g} / \mathrm{g}$ dry weight usually did. Concentrations of selenium between 9 and $60 \mu \mathrm{g} / \mathrm{g}$ may or may not have caused teratogenesis and required observation on a case-by-case basis. The number of waterbird embryos (mallard, avocet, killdeer, and teal species and coot) having concentrations of selenium in each of these three concentration categories is listed in table 17.

Table 17.--Number of bird embryo samples in each of three seleniumconcentration categories at each sampling site or group of sampling sites

[See fig. 7 for site location]

\begin{tabular}{|c|c|c|c|}
\hline \multirow[b]{2}{*}{$\begin{array}{l}\text { Site (s) } \\
\text { (species) }\end{array}$} & \multicolumn{3}{|c|}{$\begin{array}{c}\text { Concentration of selentum in waterbird embryos, } \\
\text { in micrograms per gram. dry weight } \\
\end{array}$} \\
\hline & Less than & $\begin{array}{l}\text { Between } 9 \\
\text { and } 60\end{array}$ & $\begin{array}{l}\text { More than } \\
\quad 60\end{array}$ \\
\hline $\begin{array}{l}\text { I-6 (mallard) } \\
\text { I-9 to I-12 (avocet) } \\
\text { I-16, I-17 (killdeer) } \\
\text { I-21 (teal species) } \\
\text { I-23 (coot) }\end{array}$ & $\begin{array}{l}0 \\
5 \\
2 \\
1 \\
4\end{array}$ & $\begin{array}{l}1 \\
0 \\
0 \\
0 \\
0 \\
0\end{array}$ & $\begin{array}{l}0 \\
0 \\
0 \\
0 \\
0\end{array}$ \\
\hline
\end{tabular}

of the 13 waterbird egg samples collected, 12 samples had selenium concentrations less than $9 \mu \mathrm{g} / \mathrm{g}$. One mallard sample collected near the 0 jo Amarillo ponds (site I-6) had a concentration of $17.6 \mu \mathrm{g} / \mathrm{g}$ dry weight. This sample; however, was the only egg collected from the four locations where selenium concentrations in water, bottom sediment, and other biota routinely were larger than established standards and criteria; additional eggs from these four locations were not available. Therefore, as stated earlier, selenium concentrations in embryos analyzed as part of this study do not accurately reflect conditions throughout the study area. 
External examinations of the seven fully formed embryos were conducted: one mallard from the ojo Amarillo Canyon drainage ponds (site I-6), two avocets from the block 3 Northwest Pond on the NIIP (site I-12), and four coots from the Hogback marsh (site I-23). All embryos were alive and appeared normal. Three additional coot embryos from a single nest in the Hogback marsh (site I-23) were incubated, hatched, raised, and released. On1y one of the embryos examined, however, was collected from the four locations where selenium concentrations in water, bottom sediment, and other biota routinely were larger than established standards and criteria.

\section{Concentrations of Pesticides in Water}

Water samples were collected from seven sites on the NIIP and analyzed for 12 triazine and other nitrogen-containing herbicides and 6 chlorophenoxy acid herbicides (table 27). Of these herbicides, the following were present in concentrations at or larger than the laboratory reporting leve1: cyanazine at three sites in the Gallegos Canyon area, 2,4-D at one site in the Gallegos Canyon area and two sites in the ojo Amarillo Canyon area, and dicamba at one site in the Gallegos Canyon area.

Water samples collected from seven sites on the NIIP were analyzed for 10 carbamate insecticides and 12 organophosphorus insecticides (table 27). At the block 3 Northwest Pond (site I-12), concentrations of methyl parathion and parathion were $0.14 \mu \mathrm{g} / \mathrm{L}$ and $0.61 \mu \mathrm{g} / \mathrm{L}$, respectively. None of these insecticides were present in concentrations at or larger than their respective laboratory reporting levels at any of the other sampled sites.

\section{Concentrations of Pesticides in Bottom Sediment}

Bottom-sediment samples from nine sites on the four irrigation projects were analyzed for concentrations of 17 organochlorine compounds, including pesticides, pesticide metabolites, and polychlorinated biphenyls (PCB's) (table 27). Concentrations at or larger than compound laboratory reporting levels included DDE at the Gallegos Canyon drainage middle pond (site I-2), ojo Amarillo Canyon (site I-7), and the East Hammond Project west drain and adjacent wetlands (site I-17); DDD and DDE at the West Hammond Project pond (site I-20); DDD, DDE, and chlordane at the Fruitland Project site (site I21), the Hogback marsh (site I-23), and the Hogback Project west drain (site I-24); and DDT, DDD, DDE, and chlordane at the Hogback Project east drain (site I-22). The maximum concentration of each of these compounds, in micrograms per kilogram, was DDT, $0.1 ; \mathrm{DDD}, 0.2 ; \mathrm{DDE}, 0.4 ;$ and chlordane, 2.0.

\section{Concentrations of Pesticides in Biota}

Fish and bird samples were collected for analysis of pesticides. Results of these analyses are 1isted in tables 28 and 29 (Supplemental data section). Acetylcholinesterase (AChE) and butyrylcholinesterase (BChE) inhibition assays were conducted on brain tissue and blood serum, respectively, of bird samples collected throughout the study area to qualitatively determine exposure to organophosphate and carbamate insecticides. The results of these assays are listed in table 30 . 
Fish in the San Juan River

Six flannelmouthed sucker whole-body composite samples were collected from San Juan River reaches A, and C through G; samples were analyzed for concentrations of 22 organochlorine compounds including pesticides, pesticide metabolites, and PCB's (table 28). Of the 132 total analytical measurements, the concentrations of organochlorine compounds in 96 analyses were less than the laboratory reporting level of $0.01 \mu \mathrm{g} / \mathrm{g}$ wet weight, and no concentration of any organochlorine compound was more than the NCBP (1984) geometric mean concentration of that compound (Schmitt and others, 1990). The maximum concentration of any organochlorine compound was $0.21 \mu \mathrm{g} / \mathrm{g}$ wet weight total PCB's in a sample collected from reach D of the San Juan River.

\section{Birds}

Each of 35 migratory bird samples collected from throughout the study area was analyzed for 22 organochlorine compounds (table 29). The bird samples included 16 adult killdeer, 7 adult Cassin's kingbirds (Tyrannus vociferans), 3 adult eastern kingbirds (Tyrannus tyrannus), 7 juvenile mallards, 1 juvenile coot, and 1 juvenile yellow-headed blackbird. of 770 total analytical measurements, concentrations of organochlorine compounds in 722 measurements were less than the laboratory reporting level of $0.01 \mu \mathrm{g} / \mathrm{g}$ wet weight. Except for DDE, the concentrations of organochlorine compounds in the remaining measurements were all less than the $1.0-\mu g / g$ wet weight criterion for protection of predators (National Academy of Sciences, 1973).

DDE was present in concentrations at or larger than the laboratory reporting level of $0.01 \mu \mathrm{g} / \mathrm{g}$ wet weight in 31 of the 35 bird samples, and in concentrations at or larger than the $1.0-\mu \mathrm{g} / \mathrm{g}$ wet weight criterion for protection of predators (National Academy of Sciences, 1973) in eight samples. All eight of these samples were killdeer. The maximum concentration of DDE in killdeer was $2.4 \mu \mathrm{g} / \mathrm{g}$ wet weight, and the median value was $0.98 \mu \mathrm{g} / \mathrm{g}$.

Netther DDT nor any of its metabolites other than DDE were present in concentrations larger than the 1aboratory reporting level of $0.01 \mu \mathrm{g} / \mathrm{g}$ in any migratory bird sample. The higher frequency of concentrations of DDE at and larger than the laboratory reporting level suggests that these birds have not been exposed to recent applications of DDT.

Cholinesterase assays were conducted on brain tissue and blood serum of migratory birds to determine possible exposure to organophosphate and carbamate insecticides (table 30). Five AChE inhibition assays were conducted on brain tissue, and three BChE inhibition assays were conducted on blood serum of adult drake mallard samples collected from wetland habitats on the NIIP in mid-May 1990. Thirty-five additional AChE and 10 additional BChE inhtbition assays were conducted on brain tissue and blood serum, respectively, from bird samples collected on wetland habitats throughout the study area from mid-June to mid-July 1990. This group included five assays of brain tissue and two assays of blood serum from adult drake mallard samples collected from wetland habitats on the NIIP. 
Hill (1988) established diagnostic ranges of AChE activity for several migratory bird species, including mallards and coots. Values of AChE activity less than the lower limit of the expected range of activity for a given species may indicate exposure to AChE activity-inhibiting compounds, which primarily are organophosphate and carbamate insecticides. The expected range is defined as the mean value plus or minus two standard deviations for the species being evaluated.

Comparison of results of assays conducted in the San Juan River area with those reported by $\mathrm{Hill}$ (1988) indicates that mallards in the San Juan River area in general, and on the NIIP specifically, may have been exposed to an unidentified AChE activity-inhibiting compound. The assays also suggest that mallards from the middle ponds in Gallegos Canyon (site I-2) may have been more severely exposed than mallards at other sites on the NIIP (table 30 ). American coots, conversely, did not appear to have been exposed to such a compound (table 18).

Table 18.--Comparison of acetylcholinesterase (AChE) activity in brain tissue of bird samples collected in the San Juan River area with diagnostic ranges of $\mathrm{AChE}$ activity

[AChE activity in micromoles per minute per gram, wet weight; diagnostic range established by $\mathrm{Hill}$ (1988); expected range, mean plus or minus two standard deviations]

\begin{tabular}{|c|c|c|c|c|c|c|}
\hline \multirow[b]{3}{*}{ Species } & \multicolumn{6}{|c|}{ Activity } \\
\hline & \multicolumn{3}{|c|}{ San Juan River area } & \multicolumn{3}{|c|}{ Diagnostic range } \\
\hline & $\begin{array}{l}\text { Number } \\
\text { of } \\
\text { samples }\end{array}$ & Range & Mean & $\begin{array}{c}\text { Number } \\
\text { of } \\
\text { samples }\end{array}$ & $\begin{array}{l}\text { Expected } \\
\text { range }\end{array}$ & Mean \\
\hline Mallard & 13 & $6.7-11.5$ & 9.7 & 11 & $9-15$ & 12 \\
\hline $\begin{array}{l}\text { American } \\
\text { coot }\end{array}$ & 6 & $20.7-24.5$ & 22.7 & 5 & $15-21$ & 18 \\
\hline
\end{tabular}

Comparison of AChE activity in adult drake mallards collected from the NIIP during the two sampling periods suggests less effect from exposure to AChE activity-inhibiting compounds in the mid-June to mid-July sampling period than in the mid-May sampling period (table 19). Comparison of BChE activities in these samples indicates a less clear trend. The trend of AChE activity may be the result of no exposure to $\mathrm{AChE}$-inhibiting compounds between the sampling periods and a partial recovery from earlier exposure; continued exposure to the same compounds at a smaller dose; or exposure to other compounds that resulted in less $A C h E$ inhibition. 
Table 19.--Cholinesterase activity in brain tissue and blood serum of adult drake mallard samples collected on the Navajo Indian Irrigation Project in mid-May 1990 and from mid-June to mid-July 1990

[Activity in micromoles of acetylthiocholine iodide hydrolyzed of brain tissue per minute per gram, wet weight; milliunits of acetylthiocholine iodide hydrolyzed per minute per milliliter of blood serum]

\begin{tabular}{|c|c|c|c|c|c|c|}
\hline \multirow[b]{3}{*}{$\begin{array}{l}\text { Sample } \\
\text { type }\end{array}$} & \multicolumn{6}{|c|}{ Activity } \\
\hline & \multicolumn{3}{|c|}{ Mid-May } & \multicolumn{3}{|c|}{ Mid-June to mid-July } \\
\hline & $\begin{array}{l}\text { Number } \\
\text { of } \\
\text { samples }\end{array}$ & Range & Median & $\begin{array}{l}\text { Number } \\
\text { of } \\
\text { samples }\end{array}$ & Range & Median \\
\hline $\begin{array}{l}\text { Brain } \\
\text { tissue }\end{array}$ & 5 & $6.7-10.3$ & 8.9 & 5 & $7.6-11.5$ & 10.3 \\
\hline $\begin{array}{l}\text { Blood } \\
\text { serum }\end{array}$ & 3 & $537-824$ & 608 & 2 & $660-708$ & 684 \\
\hline
\end{tabular}

\section{Concentrations of Hydrocarbons in Water}

Water samples from all three ponds in the Gallegos Canyon drainage (sites I-1, I-2, and I-3), from the East Hammond Project pond one-tenth mi north of the west drain (site I-18), and from a wetland near the Gallegos Canyon drainage south pond (site $I-1$ ) that receives runoff from the area surrounding an oil production well were collected and analyzed for hydrocarbon compounds by gas chromatographic/flame ionization detection (GC/FID scans). These sites were chosen because of their proximity to oil and gas production activity.

On the basis of results of these initial GC/FID scans, the East Hammond Project pond one-tenth mi north of the west drain (site I-18) and the wetland near the Gallegos Canyon drainage south pond (site I-1) were selected for further analysis by gas chromatography/mass spectrometry for 34 hydrocarbon compounds. The results of these two analyses indicate that none of the 34 compounds were present in concentrations at or larger than their respective laboratory reporting levels. 


\section{SUMMARY}

Data collected in 1990 and compared to established standards and criteria indicate that selenium is the major trace element of concern in all sampled media (water, bottom sediment, and biota) at six sites in four locations within the San Juan River study area. These locations are the Gallegos Canyon drainage middle and north ponds on the NIIP (sites I-2 and I-3), two sites in the 0 jo Amarillo Canyon drainage on the NIIP (I-6 and I-7/I-8), the West Hammond Project pond (I-20), and the Hogback Project east drain (I-22).

Concentrations of selenium in all media from these locations routinely exceeded established standards and criteria. The concentration of selenium in 11 water samples from these locations exceeded the State of New Mexico standard of $5 \mu \mathrm{g} / \mathrm{L}$ for the protection of fisheries. The water at these locations supports pond and wetland communities and provides habitat for waterfow1. A wetland at the outfall of the Hogback Project east drain provides habitat for San Juan River fish. The concentration of selenium in water from these locations has the potential to cause significant harmful effects to fish and wildlife.

Concentrations of selenium in 8 of 12 bottom-sediment samples collected from irrigation projects exceeded the baseline concentration for soils in the Western United States. The median selenium concentration in these 12 samples was $1.75 \mu \mathrm{g} / \mathrm{g}$ compared with a geometric mean concentration of $0.23 \mu \mathrm{g} / \mathrm{g}$ in soils in the Western United States. Selenium concentrations in five bottomsediment samples from the Gallegos Canyon drainage middle pond on the NIIP, 0 jo Amarillo Canyon, and the Hogback Project ranged from 4.5 to $37 \mu \mathrm{g} / \mathrm{g}$.

Plant samples from the middle pond of Gallegos Canyon and from the Hogback Project east drain and invertebrate samples from three sites in the Gallegos Canyon drainage, one site in the ojo Amarillo Canyon drainage, the Hogback Project east drain, and the West Hammond pond had concentrations of selenium within or larger than the 4- to $8-\mu \mathrm{g} / \mathrm{g}$ dietary threshold criterion for waterfowl food items. The selenium concentration at five of the six sites of invertebrate samples also was larger than the $5-\mu \mathrm{g} / \mathrm{g}$ dietary threshold criterion for fish food items.

The concentration of selenium in five waterdog samples from Gallegos Canyon and 0 jo Amarillo Canyon drainages on the NIIP was within or larger than the 4- to 8- $\mathrm{gg} / \mathrm{g}$ dietary threshold criterion for waterfowl food items. The selenium concentration in four of these five samples was larger than the 5$\mu \mathrm{g} / \mathrm{g}$ dietary threshold criterion for fish food items.

Selenium concentrations in six fish samples (mosquitofish, killifish, fathead minnow, common carp, and flannelmouthed sucker) collected from the Hogback Project east drain (site I-22) and the West Hammond pond (site I-20) were larger than the dietary threshold criteria for waterfowl or fish food items. Selenium concentrations in these fish also were larger than the 12$\mu \mathrm{g} / \mathrm{g}$ whole-body concentration above which reproductive failure could occur. All 13 samples of flannelmouthed sucker had concentrations of selenium larger than the 85 th-percentile concentration for the NCBP, and the median concentration of samples collected from the San Juan River was approximately twice the 85 th-percentile concentration in suckers collected for the NCBP. 
The selenium concentration in all but 2 of the 13 samples was less than the 4to $8-\mu \mathrm{g} / \mathrm{g}$ criterion for waterfowl food items; the selenium concentration in al1 but 1 of the 13 samples was less than the $5-\mu \mathrm{g} / \mathrm{g}$ criterion for fish food items. Samples with selenium concentrations larger than these criteria were from river reach $A$, from the Hammond Project Diversion to Blanco, which is upstream from DOI-sponsored irrigation. Concentrations of selenium in common carp and flannelmouthed sucker did not vary significantly between spring and fall samples, suggesting that fish were not being exposed to larger selenium concentrations during the irrigation season.

Eleven of 15 plant samples, 6 of 15 invertebrate samples, 1 of 9 amphibian samples, and 4 of 14 fish samples collected from sites on irrigation projects had concentrations of lead larger than the criterion for animal protection of about $1 \mu \mathrm{g} / \mathrm{g}$ dry weight. Four of 13 samples of both common carp and flannelmouthed sucker had lead concentrations larger than the 85 thpercentile concentration in these species collected for the NCBP. Four of 13 samples of flannelmouthed sucker had mercury concentrations larger than the 85th-percentile concentration in suckers collected for the NCBP.

Forty-six adult waterbird samples consisting of six species were collected from seven sites or site groups on irrigation projects. Median selenium concentrations in liver and kidney tissue were determined for birds collected from each of the seven areas. The median selenium concentration in Gallegos Canyon ( $31.2 \mu \mathrm{g} / \mathrm{g}$ dry weight) was larger than the $30-\mu \mathrm{g} / \mathrm{g}$ concentration above which teratogenesis can be expected to occur. No waterfow1 embryos were available from Gallegos Canyon drainage to confirm or deny that teratogenesis was occurring. The median selenium concentrations in 0 jo Amarillo Canyon $(20.5 \mu \mathrm{g} / \mathrm{g}$ dry weight) and at three other sites or site groups ( 12.5 to $16.2 \mu \mathrm{g} / \mathrm{g}$ dry welght) were within the 10 - to $30-\mu \mathrm{g} / \mathrm{g}$ range where the potential for teratogenesis exists.

Sixteen of 310 determinations for four classes of pesticides in selected water samples from the NIIP ( 40 compounds) indicated concentrations larger than reporting levels. The largest concentration of any of these compounds was $4.9 \mu \mathrm{g} / \mathrm{g}$ atrazine in the sample from the Gallegos Canyon drainage south pond (site $I-1$ ).

Eighteen of 170 determinations for organochlorine compounds in bottom sediment (analysis for 17 compounds in each of 10 samples) indicated concentrations larger than laboratory reporting levels. The largest concentration of any of these compounds was $2.0 \mu \mathrm{g} / \mathrm{g}$ chlordane in a sample from the Hogback Project west drain (site I-24).

Thirty-six of 132 determinations for organochlorine compounds in flannelmouthed sucker (analysis for 22 compounds in each of six samples) indicated concentrations at or larger than the laboratory reporting level of $0.01 \mu \mathrm{g} / \mathrm{g}$ wet weight. No concentration of any compound was as large as its respective NCBP geometric mean concentration. The largest organochlorine compound concentration was $0.21 \mu \mathrm{g} / \mathrm{g}$ wet weight total PCB's in a sample from river reach $D$. 
Forty-eight of 770 determinations for organochlorine compounds in bird samples (analysis for 22 compounds in each of 35 samples) indicated concentrations at or larger than the laboratory reporting level of $0.01 \mu \mathrm{g} / \mathrm{g}$ wet weight; 31 of these were DDE. Concentrations of DDE in eight killdeer samples were at or larger than the $1.0-\mu \mathrm{g} / \mathrm{g}$ wet-weight criterion for protection of predators. The maximum concentration of DDE in killdeer was 2.4 $\mu \mathrm{g} / \mathrm{g}$ wet weight.

Results of cholinesterase enzyme activity assays for brain tissue and blood serum suggest that mallards in the San Juan River area in general, and in Gallegos Canyon on the NIIP specifically, may have been exposed to unidentified cholinesterase activity-inhibiting compounds. 
Bellrose, F.C., 1976, Ducks, geese, and swans of North America: Harrisburg, Pa., Stackpole Books, p. 229-243.

Bunck, C.M., Prouty, R.M., and Krynitsky, A.J., 1987, Residues of organochlorine pesticides and polychlorinated biphenyls in starlings ( Sturnus vulgaris) from the continental United States, 1982: Environmental Monitoring and Assessment 8, p. 59-75.

Dane, C.H., and Bachman, G.0., 1965, Geologic map of New Mexico: U.S. Geological Survey, 2 sheets, scale 1:500,000.

Edwards, T.K., and Glysson, G.D., 1988, Field methods for measurement of fluvial sediment: U.S. Geological Survey Open-File Report 86-531, 118 p.

Eisler, Ronald, 1987, Mercury hazards to fish, wildlife, and invertebrates-A synoptic review: U.S. Fish and Wildlife Service Biological Report 85 $(1.10), 90 \mathrm{p}$.

Federal Register, 1990: v. 55, no. 99, May 22, 1990, p. 21, 154-161. 1991: v. 56, no. 20, January 30, 1991, p. 3526-3597.

Fenneman, N.M., 1931, Physiography of the western United States: New York, McGraw-Hill, 534 p.

Fishman, M.J., and Friedman, L.C., eds., 1989, Methods for determination of inorganic substances in water and fluvial sediments: U.S. Geological Survey Techniques of Water-Resources Investigations, book 5, chap. A1, $545 \mathrm{p}$.

Friedman, L.C., and Erdmann, D.E., 1982, Quality assurance practices for the chemical and biological analyses of water and fluvial sediments: U.S. Geological Survey Techniques of Water-Resources Investigations, book 5 , chap. $\mathrm{A} 6,181 \mathrm{p}$.

Heinz, G.H., Hoffman, D.J., and Gold, L.G., 1989, Impaired reproduction of mallards fed an organic form of selenium: Journal of Wildlife Management 53 (2), p. 418-428.

Hill, E.F., 1988, Brain cholinesterase activity of apparently normal wild birds: Journal of Wildlife Diseases 24 (1), p. 51-61.

Irwin, R.J., 1988, Impacts of toxic chemicals on Trinity River fish and wildlife: U.S. Fish and Wildlife Service, Fort Worth, Tex., 82 p.

Kemp, H.T., Little, R.L., Holoman, V.L., and Darby, R.L., 1973, Water quality criteria data book - Volume 5--Effects of chemicals on aquatic life: U.S. Environmental Protection Agency 18050, 502 p.

Lemly, D.A., and Smith, G.J., 1987, Aquatic cycling of selenium-Implications for fish and wildlife: U.S. Fish and Wildlife Service Leaflet $12,10 \mathrm{p}$. 


\section{SELECTED REFERENCES--Continued}

Lowe, T.P., May, T.W., Brumbaugh, W.G., and Kane, D.A., 1985, Nationa1 Contaminant Biomonitoring Program--Concentrations of 7 elements in freshwater fish, 1978-81: Archives of Environmental Toxicology 14, p. 363-388.

Meneely, S.C., Duzan, S.L., and Schemnitz, S.D., 1979, Impacts of uranium mining and milling upon fish and wildlife resources of the New Mexico San Juan Basin Region: Las Cruces, New Mexico State University, Department of Fishery and Wildlife Sciences, $214 \mathrm{p}$.

National Academy of Sciences, National Academy of Engineering, 1973, Section III--Freshwater aquatic life and wildife, water quality criteria: Ecological Research Series, EPA-R3-73-033, p. 106-113.

New Mexico Water Quality Contro1 Commission, 1988, Water-quality standards for interstate and intrastate streams in New Mexico as amended through March 8, 1988: New Mexico State modifying rule no. 88-1, 48 p.

O'Brien, T.F., 1987, Organochlorine and heavy metal contaminant investigation, San Juan River Basin, New Mexico: U.S. Fish and Wildlife Service, Albuquerque, N. Mex., 21 p.

Ohlendorf, H.M., Hothem, R.L., Bunck, C.M., and Marois, K.C., 1990, Bioaccumulation of selenium in birds at Kesterson Reservoir, California: Archives of Environmental Contamination and Toxicology, v. 19, p. 495507.

Ong, Kim, O'Brien, T.F., and Rucker, M.D., 1991, Reconnaissance investigation of water quality, bottom sediment, and biota associated with irrigation drainage in the middle Rio Grande valley and Bosque del Apache National Wildlife Refuge, New Mexico, 1988-89: U.S. Geological Survey WaterResources Investigations Report 91,-4036, 113 p.

Schmitt, C.J., and Brumbaugh, W.G., 1990, National Contaminant Biomonitoring Program--Concentrations of arsenic, cadmium, copper, lead, mercury, selenium, and zinc in U.S. freshwater fish, 1976-84: Archives of Environmental Contaminant Toxicology 19, p. 731-747.

Schmitt, C.J., Zajicek, J.L., and Peterman, P.A., 1990, National Contaminant Biomonitoring Program--Residues of organochlorine chemicals in U.S. freshwater fish: Archives of Environmental Contaminant Toxicology 19, p. $748-781$.

Severson, R.C., and Gough, L.P., 1981, Geochemical variability of natural soils and reclaimed mine-spoil soils in the San Juan Basin, New Mexico: U.S. Geological Survey Professional Paper 1134-C, 39 p.

Severson, R.C., Stewart, K.C., and Harms, T.F., 1991, Partitioning of elements between two size sediment fractions in samples from nineteen areas of the Western United States: U.S. Geological Survey Open-File Report 91-381, $18 \mathrm{p}$. 
Severson, R.C., Wilson, S.A., and McNeal, J.M., 1988, Analysis of bottom material collected at nine areas in the Western United States for the DOI irrigation drainage task group: U.S. Geological Survey Open-File Report $87-490,24 \mathrm{p}$.

Shacklette, H.T., and Boerngen, J.G., 1984, Element concentrations in soils and other surficial materials of the conterminous United States: U.S. Geological Survey Professional Paper 1270, 10 p.

Skorupa, J.P., and Ohlendorf, H.M., 1991, Contaminants in drainwater and avian risk thresholds, in The economics and management of water and drainage in agriculture, Ariel Dinar and David Zilberman, eds.: Kluwer Academic Publishers, p. 345-368.

Skorupa, J.P., Ohlendorf, H.M., and Hothem, R.L., 1990, Selenium bioaccumulation and biological risk--Some interpretive guidelines for waterbirds derived from field sampling: Conference of the Western Section and Northwest Section of the Wildlife Society, February 22-25, 1990, Reno, Nev.

Thatcher, L.L., Janzer, V.J., and Edwards, K.W., 1977, Methods for determination of radioactive substances in water and fluvial sediments: U.S. Geological Survey Techniques of Water-Resources Investigations, book 5, chap. A5, 95 p.

U.S. Bureau of Reclamation, 1980, Final environmental statement, Animas-La Plata Project: Colorado-New Mexico Upper Colorado Region.

U.S. Department of Commerce, 1990, Climatological data, New Mexico: Nationa1 Oceanic and Atmospheric Administration, v. 94, nos. 1-12.

U.S. Environmental Protection Agency, 1985, Methods for measuring the acute toxicity of effluents to freshwater and marine organisms ( $3 \mathrm{~d}$ ed.): U.S. Environmental Protection Agency Report 600/4-85-013, 216 p.

1986a, Maximum contaminant levels (Subpart B of Part 141, National interim primary drinking-water regulations): U.S. Code of Federal Regulations, Title 40, Parts 100 to 149, revised as of July 1, 1986, p. 524-528.

1986b, Secondary maximum contaminant levels (Section 143.3 of Part 143, National secondary drinking-water regulations): U.S. Code of Federal Regulations, Tit1e 40, Parts 100 to 149, revised as of July 1, 1986, p. 587-590.

1987, Ambient water-quality criteria for selenium--1987: U.S. Environmental Protection Agency Report 440/5-87-006, 121 p.

U.S. Fish and Wildlife Service, 1985, Field operations manual for resource contaminant assessment: U.S. Fish and Wildlife Service, J. Hickey, ed., $333 \mathrm{p}$. 


\section{SELECTED REFERENCES - - Concluded}

U.S. Fish and Wildlife Service, 1990, Patuxent Analytical Control Facility reference manual: U.S. Fish and Wildlife Service, Laurel, Md., 120 p.

U.S. Geological Survey, 1971-75, Watex resources data for New Mexico, 1970-74--Part 2. Water-quality records: U.S. Geological Survey WaterData Reports NM-70-2 to NM-74-2 (published annually).

1976-91, Water resources data for New Mexico, water years 1975-90: U.S. Geological Survey Watex-Data Reports NM-75-1 to NM-90-1 (pub1ished annually).

$1982 \mathrm{~b}$, Chemical and physical quality of water and sediment, in National handbook of recommended methods for water-data acquisition: Office of Water Data Coordination, Reston, Va., chap. 5, 194 p.

Wershaw, R.L., Fishman, M.J., Grabbe, R.R., and Lowe, L.E., 1987, eds., Methods for determination of organic substances in water and fluvial sediments: U.S. Geological Survey Techniques of Water-Resources Investigations, book 5, chap. A3, 80 p.

White, D.H., Bean, J.R., and Longcore, J.R., 1977, Nationwide residues of mercury, lead, cadmium, arsenic, and selenium on starlings, 1973: Pesticide Monitoring Journal, v. II, no. 1, p. 35-39.

Wilson, Brian, 1986, Water use in New Mexico: New Mexico State Engineer Office Technical Report 46, 84 p. 
SUPPLEMENTAL DATA 


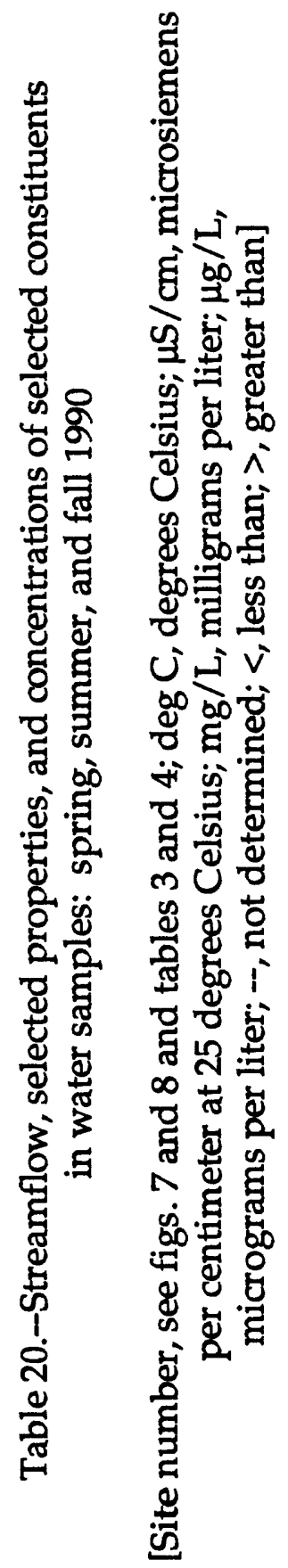

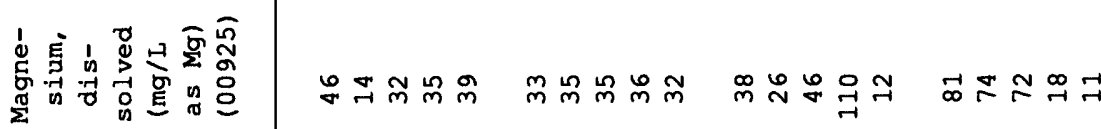

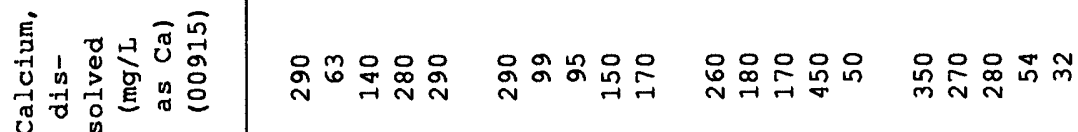

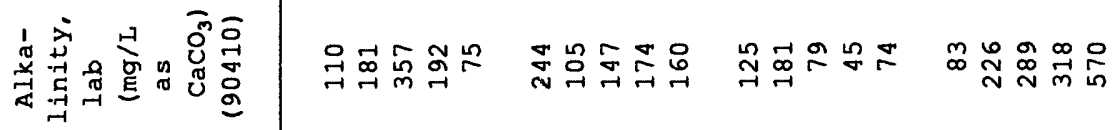

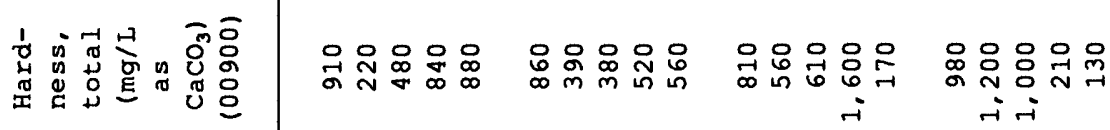

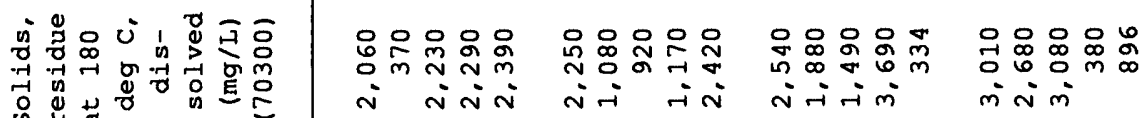

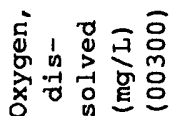

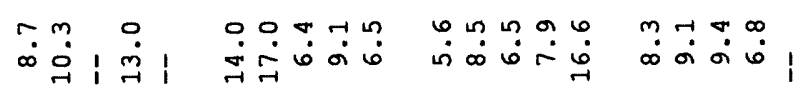

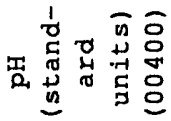

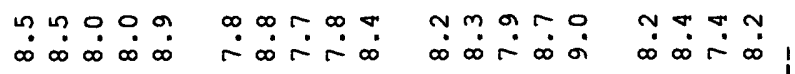

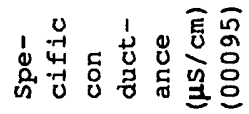

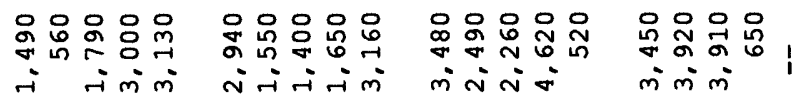

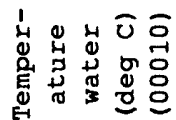

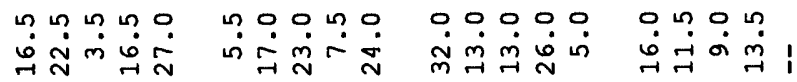

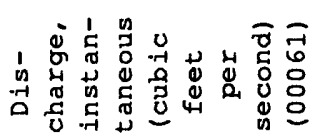

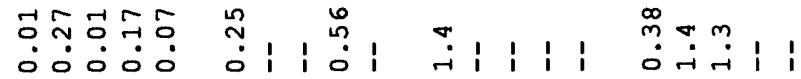

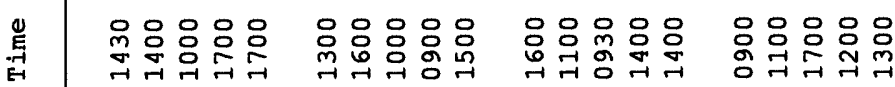

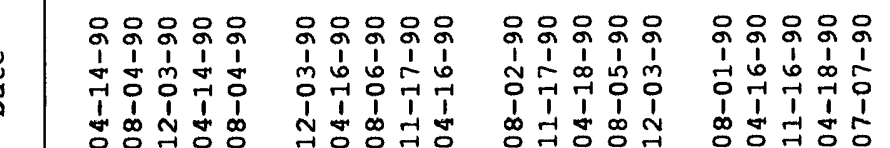

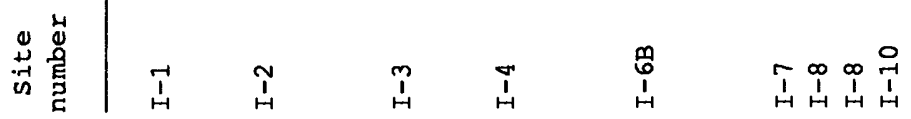




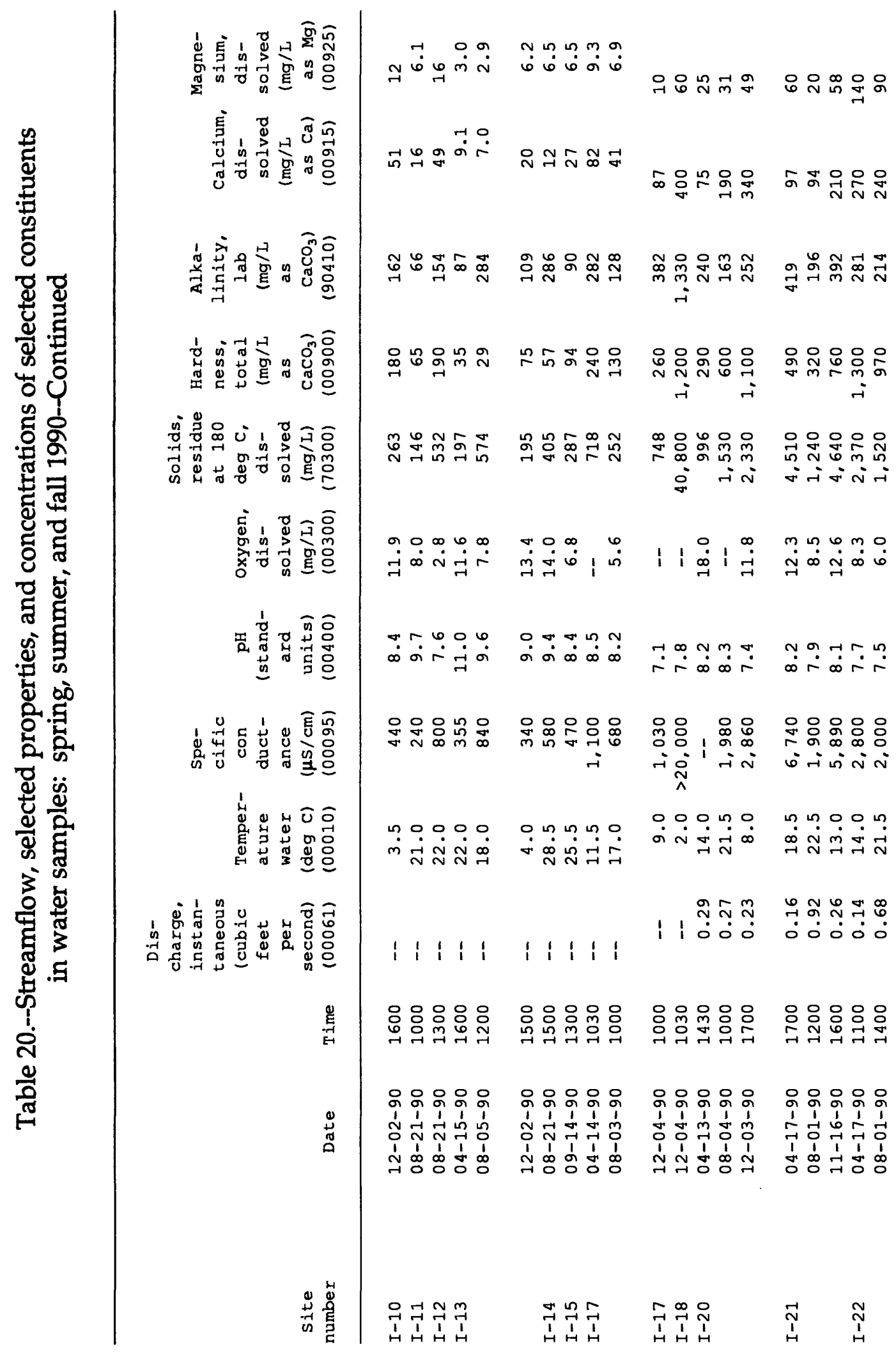




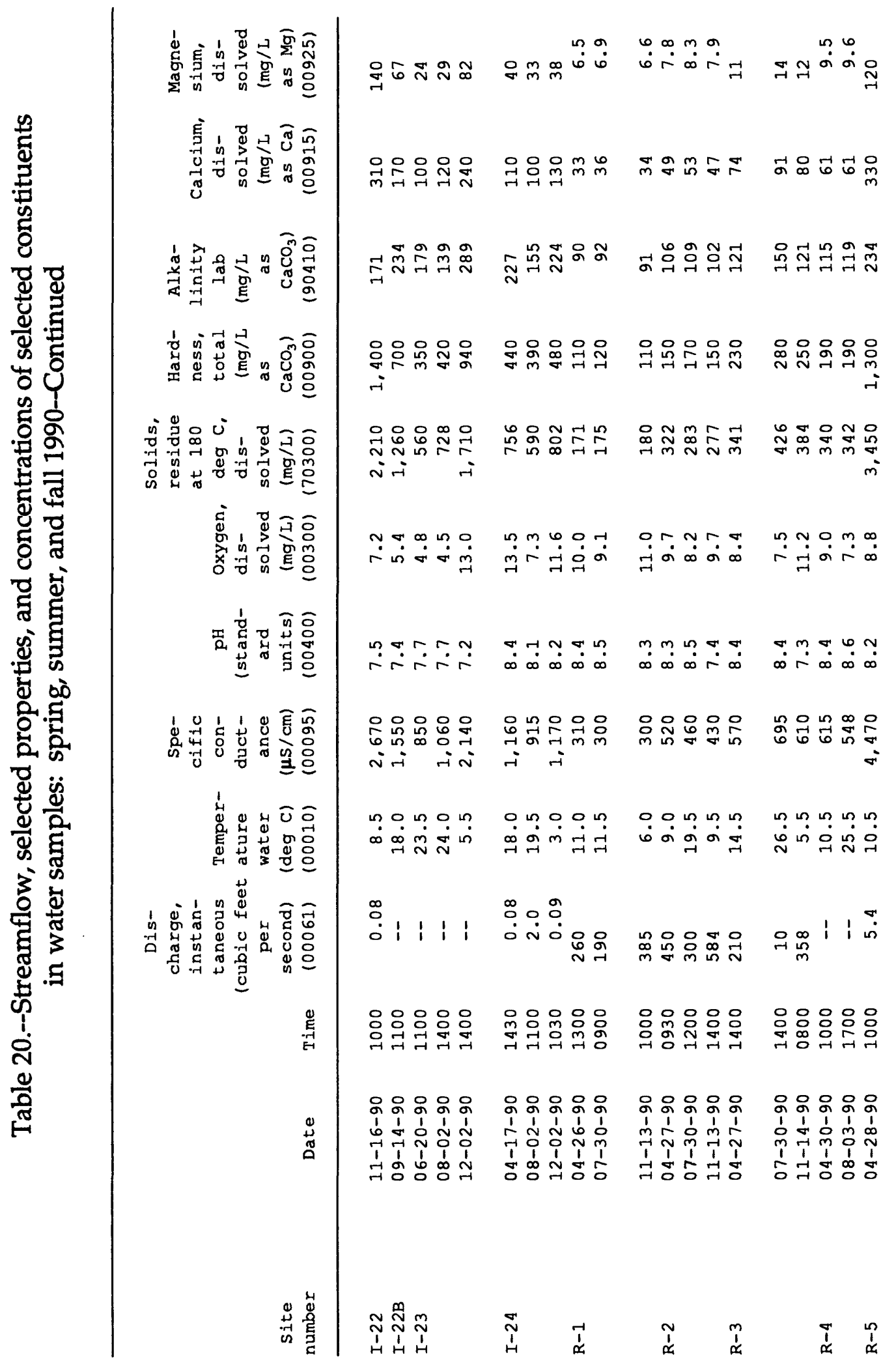




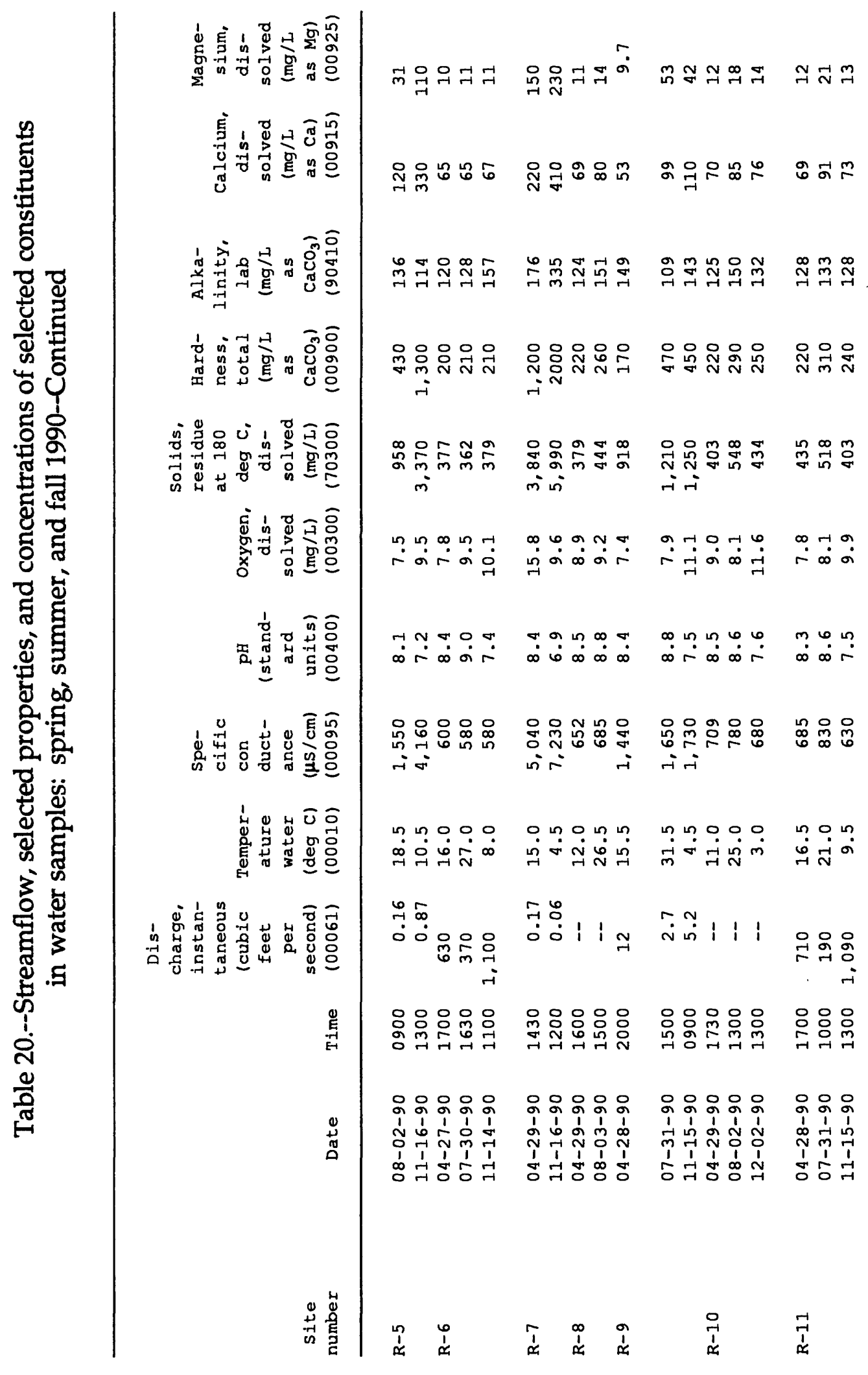




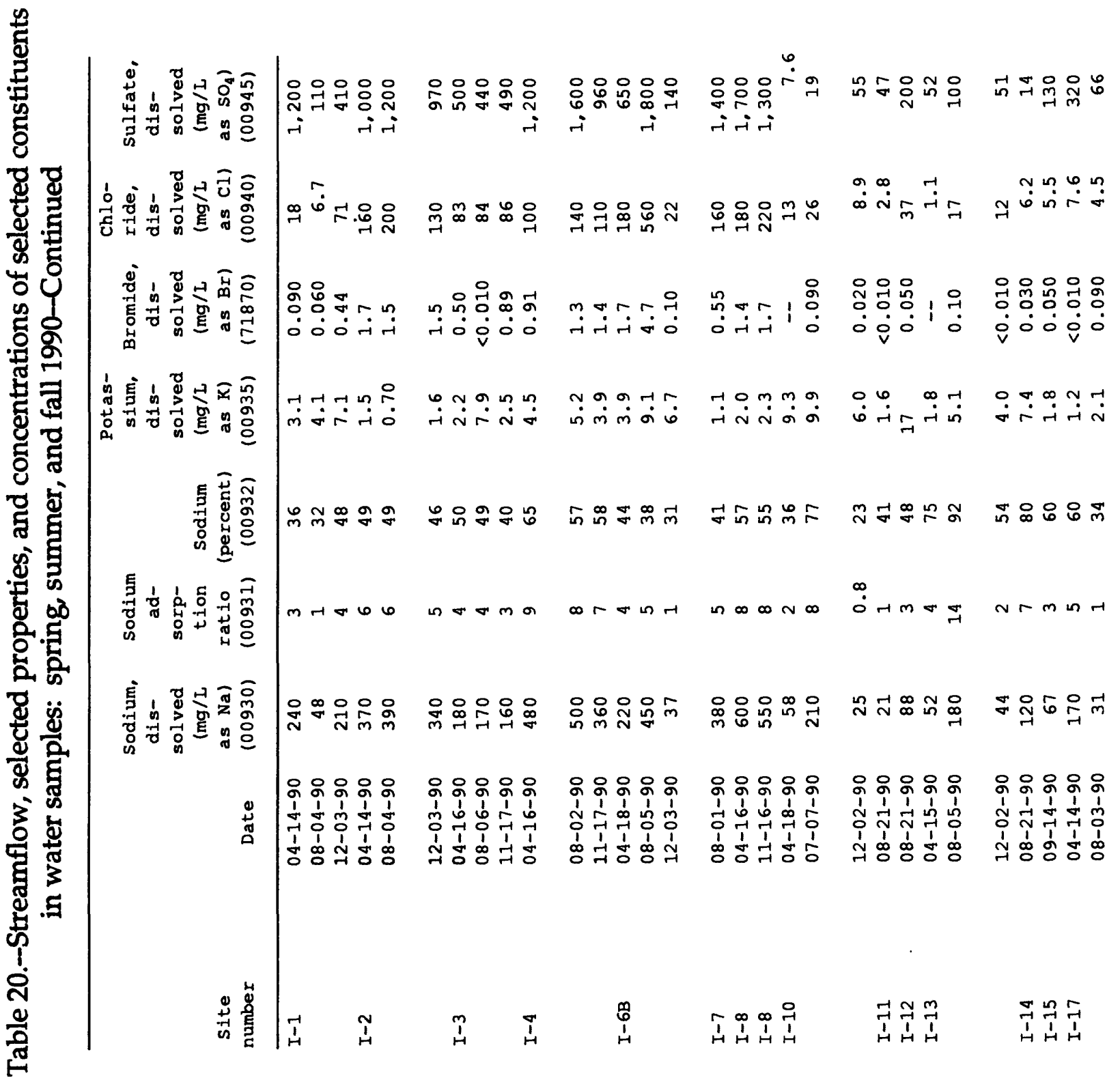




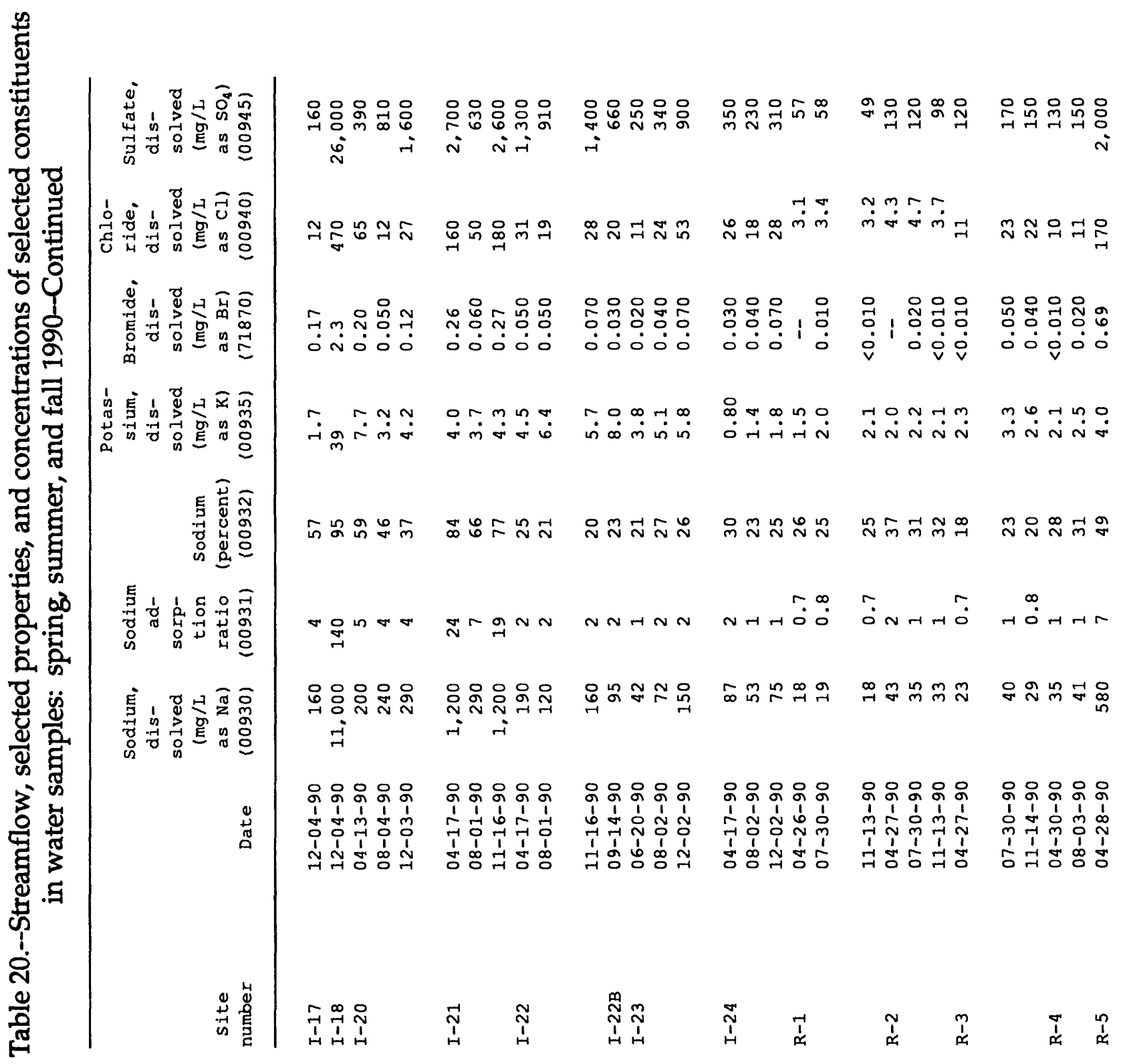




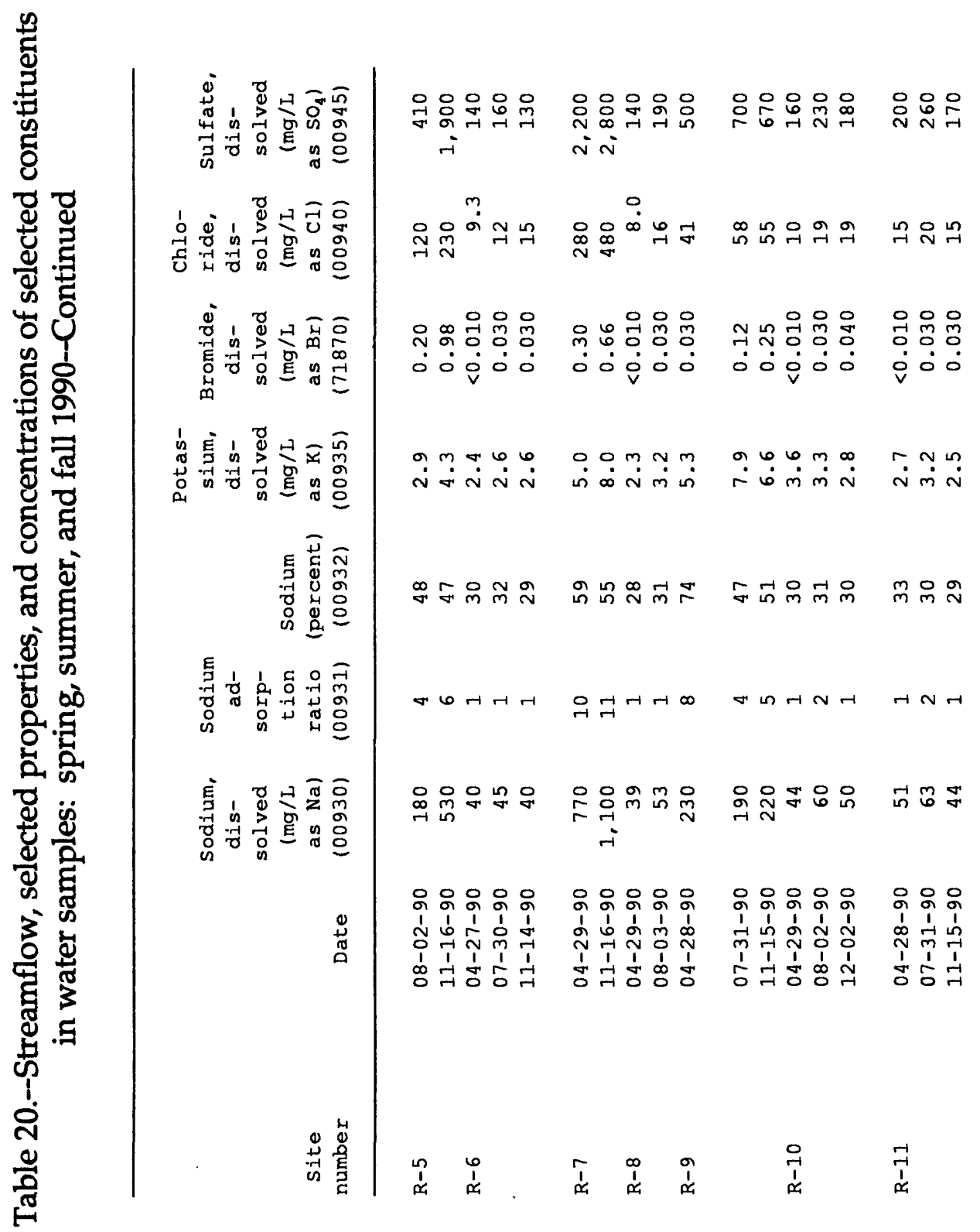




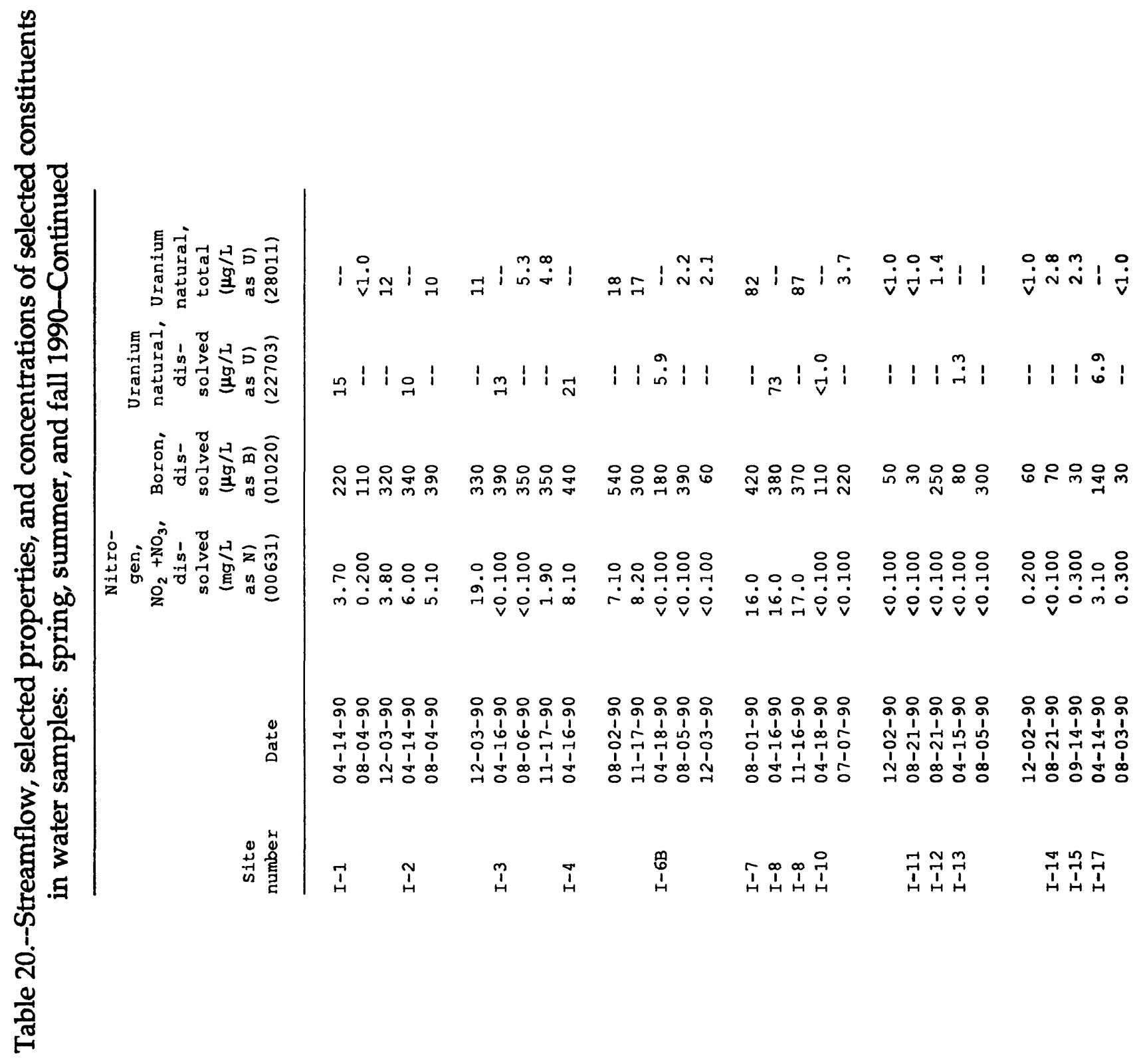




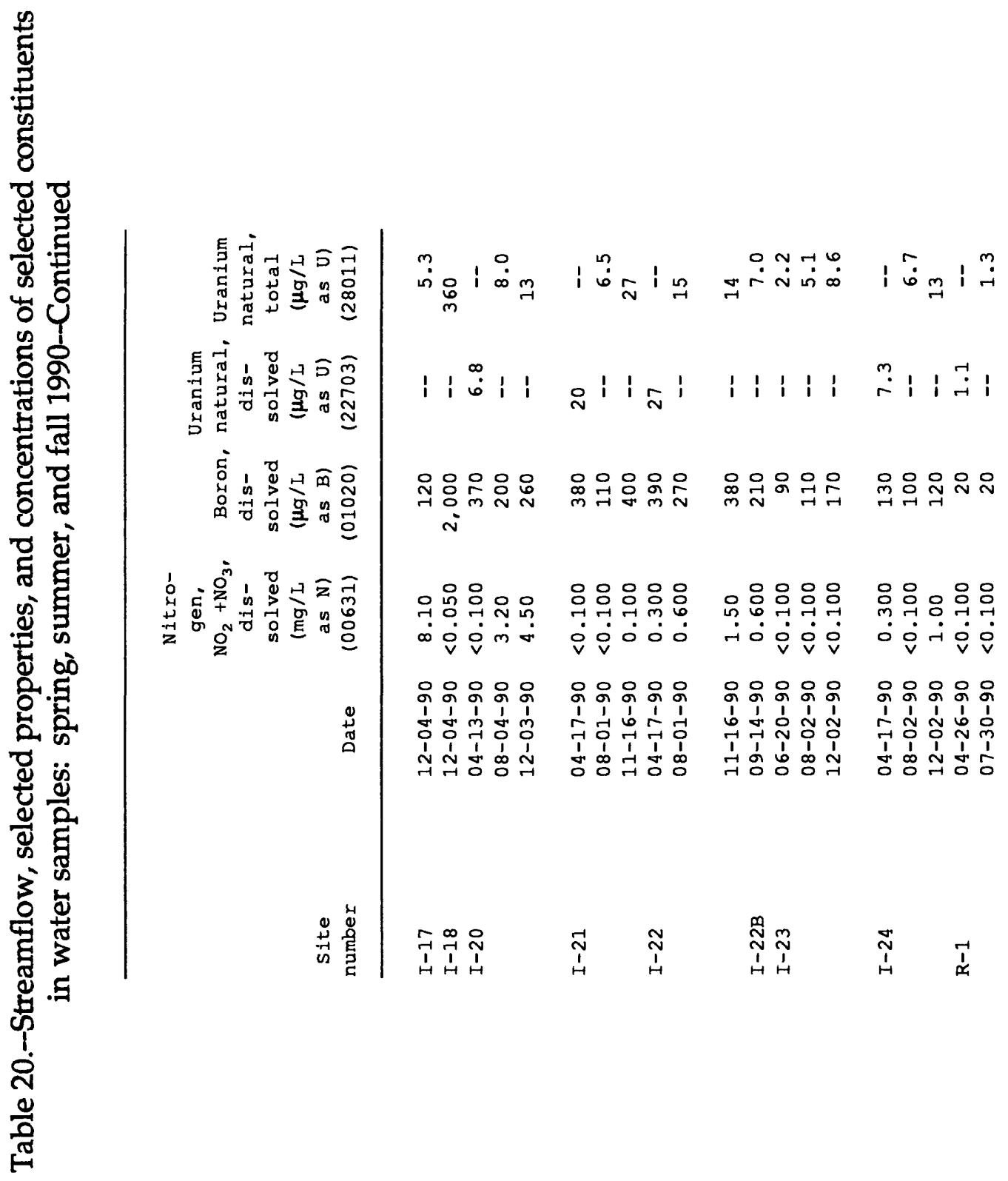




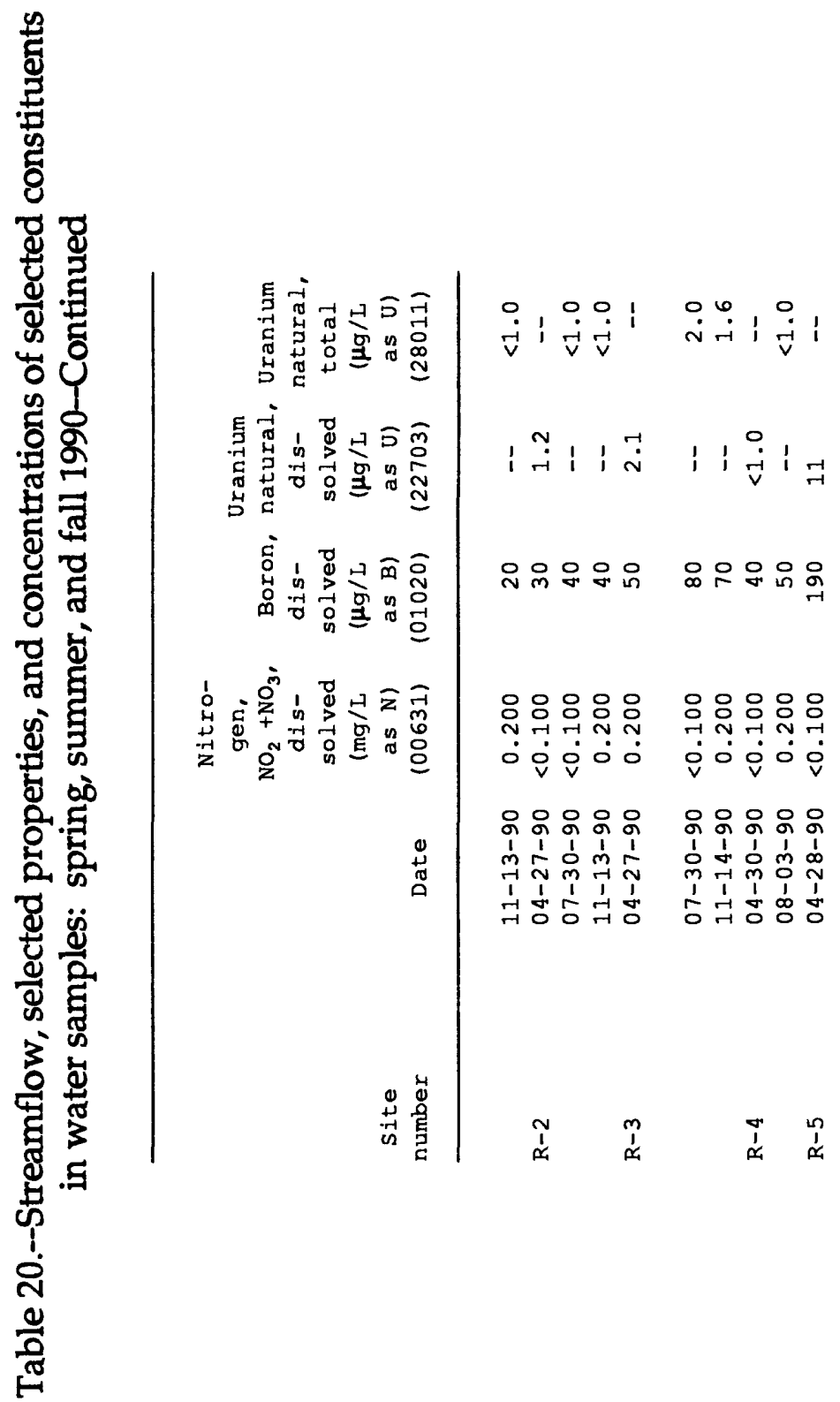


草

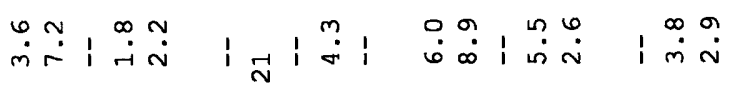

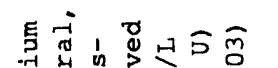

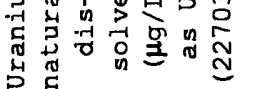

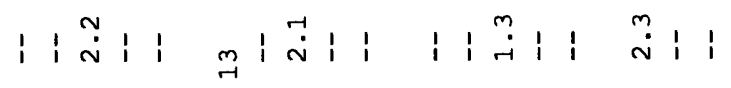

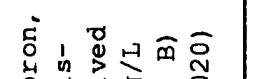

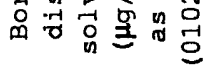

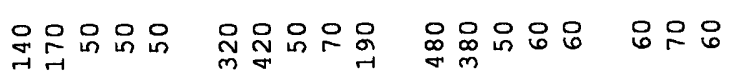

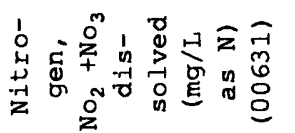

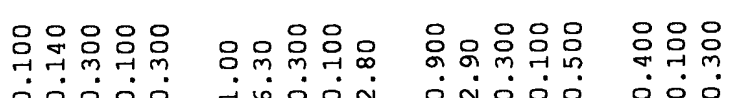

过家o

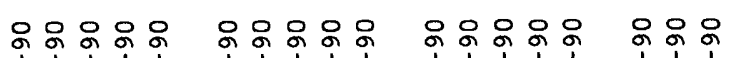

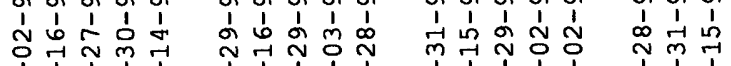

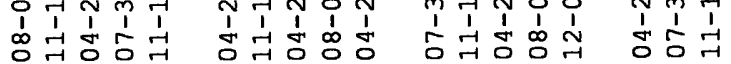

总

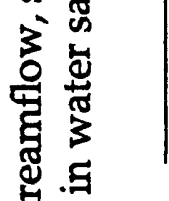

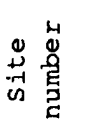

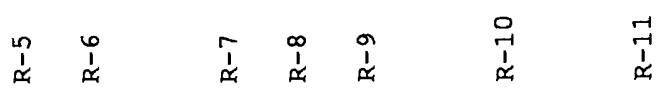

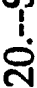

है⿴囗十 


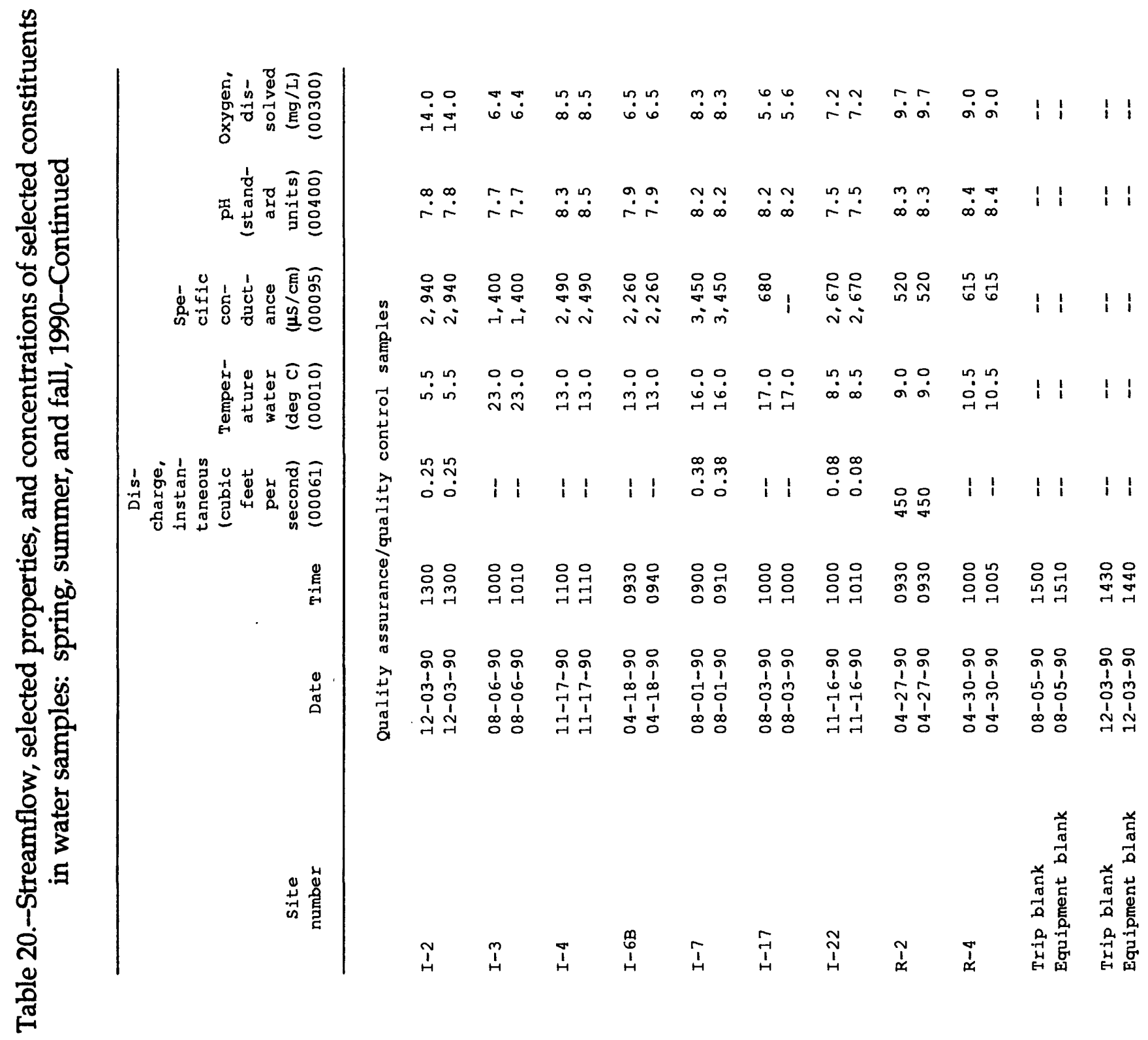




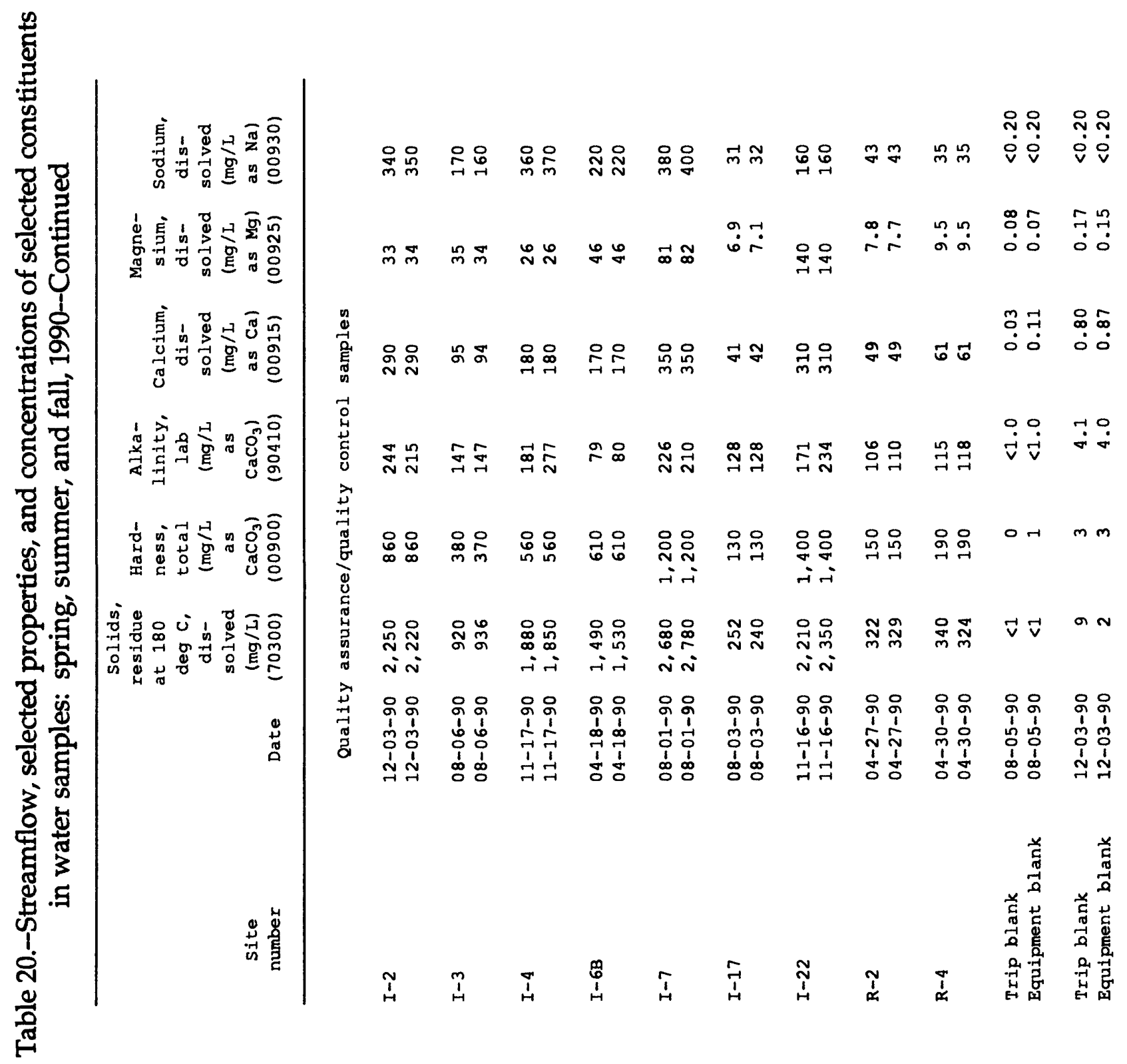




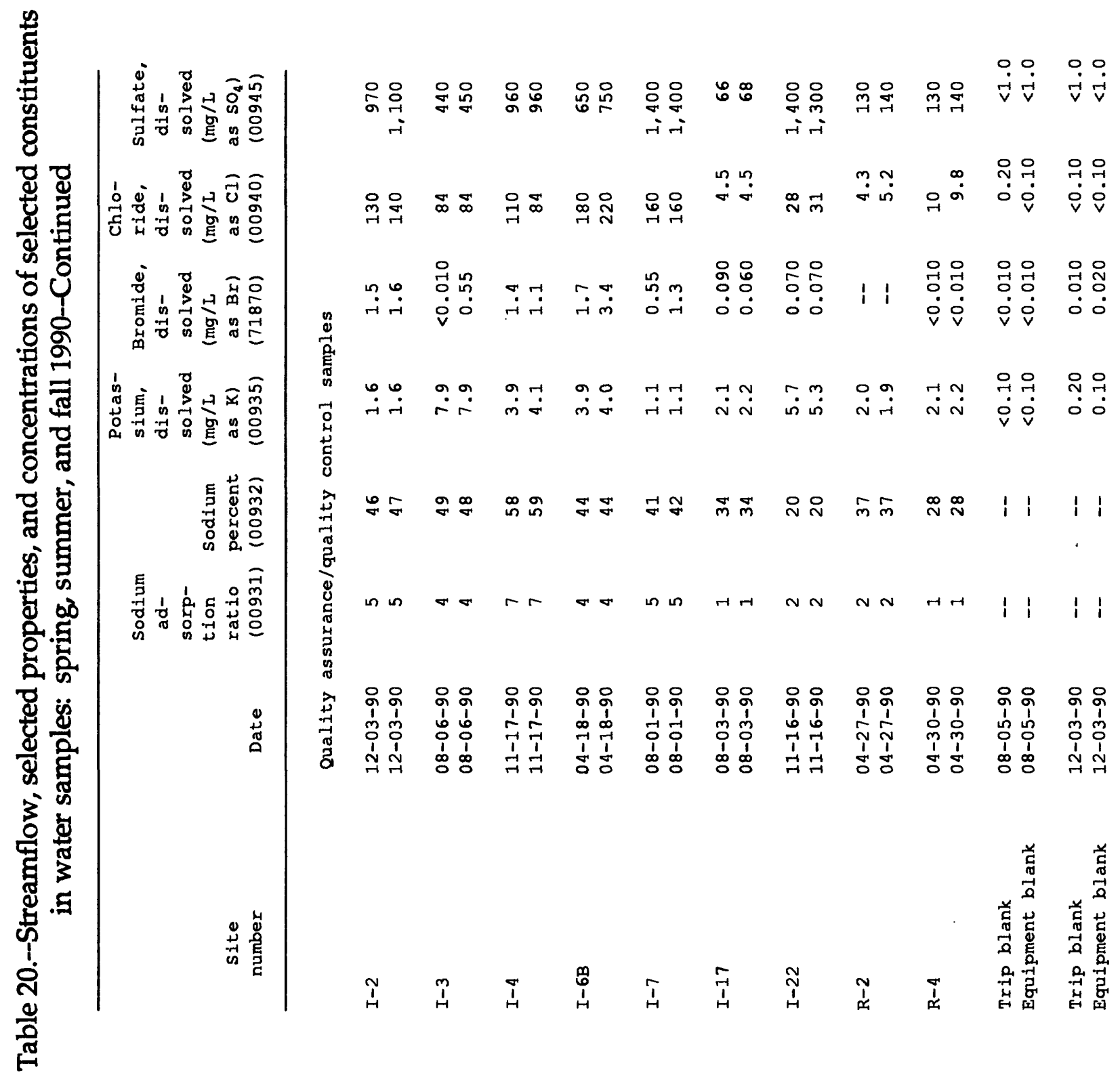


苞

莺兽|

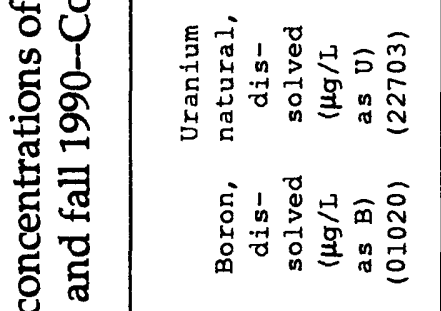

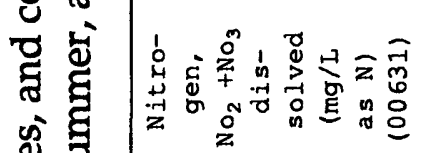

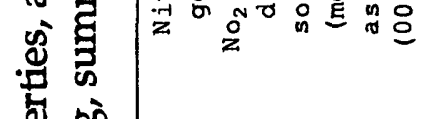

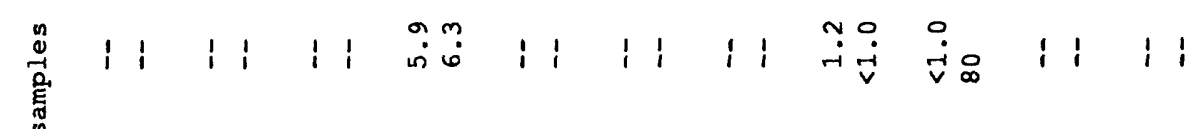

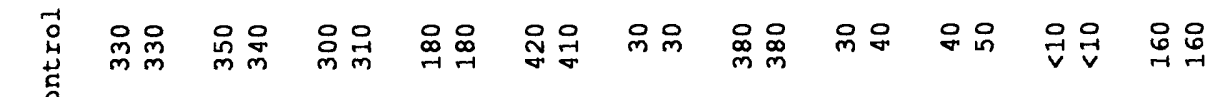

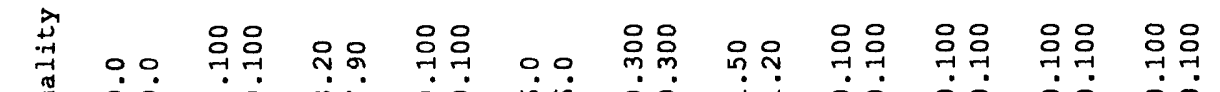
节 总言

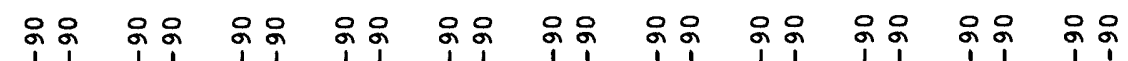

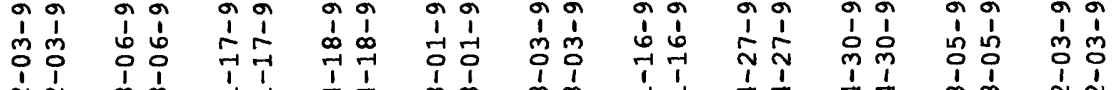

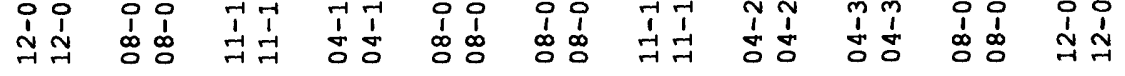

ఫृँ 造㲅

家

密离

竞总

กิ่

䒕

I 
Table 21.--Streamflow and concentrations of trace elements in water samples: spring, summer, and fall 1990

[Site number, see figs. 7 and 8 and tables 3 and 4;

$\mu \mathrm{g} / \mathrm{L}$, micrograms per 11ter; --, not measured; <, less than]

\begin{tabular}{|c|c|c|c|c|c|c|c|}
\hline $\begin{array}{c}\text { Site } \\
\text { number }\end{array}$ & Date & Time & $\begin{array}{l}\text { Dis- } \\
\text { charge, } \\
\text { instan- } \\
\text { taneous } \\
\text { (cubic } \\
\text { feet } \\
\text { per } \\
\text { second) } \\
(00061)\end{array}$ & $\begin{array}{c}\text { Arsenic, } \\
\text { dis - } \\
\text { solved } \\
(\mu \mathrm{g} / \mathrm{L} \\
\text { as As) } \\
(01000)\end{array}$ & $\begin{array}{c}\text { Cadmium, } \\
\text { dis - } \\
\text { solved } \\
(\mu \mathrm{g} / \mathrm{L} \\
\text { as Cd) } \\
(01025)\end{array}$ & $\begin{array}{c}\text { Chro- } \\
\text { mium, } \\
\text { dis- } \\
\text { solved } \\
(\mu \mathrm{g} / \mathrm{L} \\
\text { as Cr) } \\
(01030)\end{array}$ & $\begin{array}{c}\text { Copper, } \\
\text { dis- } \\
\text { solved } \\
(\mu \mathrm{g} / \mathrm{L} \\
\text { as } \mathrm{Cu}) \\
(01040)\end{array}$ \\
\hline I - 1 & $\begin{array}{l}04-14-90 \\
08-04-90 \\
12-03-90 \\
04-14-90 \\
08-04-90\end{array}$ & $\begin{array}{l}1430 \\
1400 \\
1000 \\
1700 \\
1700\end{array}$ & $\begin{array}{l}0.01 \\
0.27 \\
0.01 \\
0.17 \\
0.07\end{array}$ & $\begin{array}{r}<1 \\
2 \\
<1 \\
<1 \\
1\end{array}$ & $\begin{array}{l}<1.0 \\
<1.0 \\
<1.0 \\
<1.0 \\
<1.0\end{array}$ & $\begin{array}{r}2 \\
<1 \\
<1 \\
2 \\
<1\end{array}$ & $\begin{array}{r}1 \\
10 \\
1 \\
31 \\
1\end{array}$ \\
\hline I -4 & $\begin{array}{l}12-03-90 \\
04-16-90 \\
08-06-90 \\
11-17-90 \\
04-16-90\end{array}$ & $\begin{array}{l}1300 \\
1600 \\
1000 \\
0900 \\
1500\end{array}$ & $\begin{array}{l}0.25 \\
-- \\
-- \\
0.56 \\
--\end{array}$ & $\begin{array}{r}<1 \\
<1 \\
3 \\
1 \\
<1\end{array}$ & $\begin{array}{r}<1.0 \\
2.0 \\
<1.0 \\
<1.0 \\
<1.0\end{array}$ & $\begin{array}{l}<1 \\
<1 \\
<1 \\
<1 \\
2\end{array}$ & $\begin{array}{l}1 \\
3 \\
1 \\
2 \\
2\end{array}$ \\
\hline$I-6 B$ & $\begin{array}{l}08-02-90 \\
11-17-90 \\
04-18-90 \\
08-05-90 \\
12-03-90\end{array}$ & $\begin{array}{l}1600 \\
1100 \\
0930 \\
1400 \\
1400\end{array}$ & $\begin{array}{l}1.4 \\
-- \\
-- \\
-- \\
--\end{array}$ & $\begin{array}{r}1 \\
<1 \\
<1 \\
3 \\
<1\end{array}$ & $\begin{array}{l}<1.0 \\
<1.0 \\
<1.0 \\
<1.0 \\
<1.0\end{array}$ & $\begin{array}{r}1 \\
1 \\
2 \\
<1 \\
<1\end{array}$ & $\begin{array}{r}4 \\
3 \\
<1 \\
1 \\
2\end{array}$ \\
\hline $\begin{array}{l}I-7 \\
I-8 \\
I-8 \\
I-10\end{array}$ & $\begin{array}{l}08-01-90 \\
04-16-90 \\
11-16-90 \\
04-18-90 \\
07-07-90\end{array}$ & $\begin{array}{l}0900 \\
1100 \\
1700 \\
1200 \\
1300\end{array}$ & $\begin{array}{l}0.38 \\
1.4 \\
1.3 \\
-- \\
--\end{array}$ & $\begin{array}{r}<1 \\
<1 \\
<1 \\
7 \\
48\end{array}$ & $\begin{array}{r}<1.0 \\
<1.0 \\
<1.0 \\
2.0 \\
<1.0\end{array}$ & $\begin{array}{r}<1 \\
2 \\
<1 \\
2 \\
1\end{array}$ & $\begin{array}{r}1 \\
1 \\
2 \\
<1 \\
32\end{array}$ \\
\hline $\begin{array}{l}\mathrm{I}-11 \\
\mathrm{I}-12 \\
\mathrm{I}-13\end{array}$ & $\begin{array}{l}12-02-90 \\
08-21-90 \\
08-21-90 \\
04-15-90 \\
08-05-90\end{array}$ & $\begin{array}{l}1600 \\
1000 \\
1300 \\
1600 \\
1200\end{array}$ & $\begin{array}{l}-- \\
-- \\
-- \\
--\end{array}$ & $\begin{array}{r}5 \\
2 \\
5 \\
3 \\
17\end{array}$ & $\begin{array}{r}<1.0 \\
<1.0 \\
1.0 \\
<1.0 \\
<1.0\end{array}$ & $\begin{array}{r}<1 \\
<1 \\
<1 \\
2 \\
<1\end{array}$ & $\begin{array}{r}1 \\
2 \\
12 \\
4 \\
13\end{array}$ \\
\hline $\begin{array}{l}\text { I }-14 \\
\text { I }-15 \\
\text { I }-17\end{array}$ & $\begin{array}{l}12-02-90 \\
08-21-90 \\
09-14-90 \\
04-14-90 \\
08-03-90\end{array}$ & $\begin{array}{l}1500 \\
1500 \\
1300 \\
1030 \\
1000\end{array}$ & $\begin{array}{l}-- \\
-- \\
-- \\
--\end{array}$ & $\begin{array}{r}1 \\
4 \\
<1 \\
<1 \\
1\end{array}$ & $\begin{array}{r}<1.0 \\
1.0 \\
<1.0 \\
<1.0 \\
<1.0\end{array}$ & $\begin{array}{r}<1 \\
<1 \\
<1 \\
1 \\
<1\end{array}$ & $\begin{array}{l}3 \\
7 \\
6 \\
3 \\
3\end{array}$ \\
\hline
\end{tabular}


Table 21.--Streamflow and concentrations of trace elements in water samples: spring, summer, and fall 1990--Continued

\begin{tabular}{|c|c|c|c|c|c|c|c|}
\hline $\begin{array}{c}\text { Site } \\
\text { number }\end{array}$ & Date & Time & $\begin{array}{l}\text { Dis- } \\
\text { charge, } \\
\text { instan- } \\
\text { taneous } \\
\text { (cubic } \\
\text { feet } \\
\text { per } \\
\text { second) } \\
(00061)\end{array}$ & $\begin{array}{c}\text { Arsenic, } \\
\text { dis- } \\
\text { solved } \\
(\mu \mathrm{g} / \mathrm{L} \\
\text { as As) } \\
(01000)\end{array}$ & $\begin{array}{c}\text { Cadmium, } \\
\text { dis- } \\
\text { solved } \\
(\mu \mathrm{g} / \mathrm{L} \\
\text { as Cd }) \\
(01025)\end{array}$ & $\begin{array}{c}\text { Chro- } \\
\text { mium, } \\
\text { dis - } \\
\text { solved } \\
(\mu \mathrm{g} / \mathrm{L} \\
\text { as } \mathrm{Cr}) \\
(01030)\end{array}$ & $\begin{array}{c}\text { Copper, } \\
\text { dis - } \\
\text { solved } \\
(\mu \mathrm{g} / \mathrm{L} \\
\text { as } \mathrm{Cu}) \\
(01040)\end{array}$ \\
\hline $\begin{array}{l}I-17 \\
I-18 \\
I-20\end{array}$ & $\begin{array}{l}12-04-90 \\
12-04-90 \\
04-13-90 \\
08-04-90 \\
12-03-90\end{array}$ & $\begin{array}{l}1000 \\
1030 \\
1430 \\
1000 \\
1700\end{array}$ & $\begin{array}{l}-- \\
-- \\
0.29 \\
0.27 \\
0.23\end{array}$ & $\begin{array}{r}<1 \\
2 \\
1 \\
<1 \\
<1\end{array}$ & $\begin{array}{l}<1.0 \\
<10 \\
<1.0 \\
<1.0 \\
<1.0\end{array}$ & $\begin{array}{l}<1 \\
<5 \\
1 \\
<1 \\
<1\end{array}$ & $\begin{array}{r}3 \\
<10 \\
1 \\
1 \\
2\end{array}$ \\
\hline $\begin{array}{l}I-21 \\
I-22\end{array}$ & $\begin{array}{l}04-17-90 \\
08-01-90 \\
11-16-90 \\
04-17-90 \\
08-01-90\end{array}$ & $\begin{array}{l}1700 \\
1200 \\
1600 \\
1100 \\
1400\end{array}$ & $\begin{array}{l}0.16 \\
0.92 \\
0.26 \\
0.14 \\
0.68\end{array}$ & $\begin{array}{r}1 \\
2 \\
1 \\
<1 \\
1\end{array}$ & $\begin{array}{l}<1.0 \\
<1.0 \\
<1.0 \\
<1.0 \\
<1.0\end{array}$ & $\begin{array}{r}2 \\
<1 \\
<1 \\
1 \\
<1\end{array}$ & $\begin{array}{r}<1 \\
2 \\
1 \\
1 \\
1\end{array}$ \\
\hline $\begin{array}{l}I-22 B \\
I-23\end{array}$ & $\begin{array}{l}11-16-90 \\
09-14-90 \\
06-20-90 \\
08-02-90 \\
12-02-90\end{array}$ & $\begin{array}{r}1000 \\
1100 \\
140 \\
1400 \\
1400\end{array}$ & $\begin{array}{l}0.08 \\
-- \\
-- \\
-- \\
--\end{array}$ & $\begin{array}{r}<1 \\
<1 \\
1 \\
1 \\
<1\end{array}$ & $\begin{array}{l}<1.0 \\
<1.0 \\
<1.0 \\
<1.0 \\
<1.0\end{array}$ & $\begin{array}{r}<1 \\
<1 \\
1 \\
<1 \\
<1\end{array}$ & $\begin{array}{l}1 \\
3 \\
1 \\
2 \\
5\end{array}$ \\
\hline $\begin{array}{l}I-24 \\
R-1\end{array}$ & $\begin{array}{l}04-17-90 \\
08-02-90 \\
12-02-90 \\
04-26-90 \\
07-30-90\end{array}$ & $\begin{array}{l}1430 \\
1100 \\
1030 \\
1300 \\
0900\end{array}$ & $\begin{aligned} & 0.08 \\
& 2.0 \\
& 0.09 \\
& 260 \\
& 190\end{aligned}$ & $\begin{array}{r}1 \\
1 \\
<1 \\
<1 \\
1\end{array}$ & $\begin{array}{l}<1.0 \\
<1.0 \\
<1.0 \\
<1.0 \\
<1.0\end{array}$ & $\begin{array}{r}1 \\
<1 \\
<1 \\
1 \\
<1\end{array}$ & $\begin{array}{l}1 \\
2 \\
2 \\
1 \\
2\end{array}$ \\
\hline$R-3$ & $\begin{array}{l}11-13-90 \\
04-27-90 \\
07-30-90 \\
11-13-90 \\
04-27-90\end{array}$ & $\begin{array}{l}1000 \\
0930 \\
1200 \\
1400 \\
1400\end{array}$ & $\begin{array}{l}385 \\
450 \\
300 \\
584 \\
210\end{array}$ & $\begin{array}{r}<1 \\
<1 \\
1 \\
<1 \\
<1\end{array}$ & $\begin{array}{r}<1.0 \\
<1.0 \\
<1.0 \\
<1.0 \\
1.0\end{array}$ & $\begin{array}{r}<1 \\
1 \\
<1 \\
<1 \\
1\end{array}$ & $\begin{array}{l}2 \\
8 \\
2 \\
1 \\
1\end{array}$ \\
\hline$R-5$ & $\begin{array}{l}07-30-90 \\
04-30-90 \\
08-03-90 \\
11-14-90 \\
04-28-90\end{array}$ & $\begin{array}{l}1400 \\
1000 \\
1700 \\
0800 \\
1000\end{array}$ & $\begin{array}{c}10 \\
\ldots \\
-- \\
358 \\
5.4\end{array}$ & $\begin{array}{r}<1 \\
<1 \\
1 \\
<1 \\
<1\end{array}$ & $\begin{array}{l}<1.0 \\
<1.0 \\
<1.0 \\
<1.0 \\
<1.0\end{array}$ & $\begin{array}{r}<1 \\
1 \\
<1 \\
<1 \\
3\end{array}$ & $\begin{array}{l}4 \\
1 \\
2 \\
2 \\
1\end{array}$ \\
\hline
\end{tabular}


Table 21.--Streamflow and concentrations of trace elements in water samples: spring, summer, and fall 1990--Continued

\begin{tabular}{|c|c|c|c|c|c|c|c|}
\hline $\begin{array}{c}\text { Site } \\
\text { number }\end{array}$ & Date & Time & $\begin{array}{l}\text { Dis- } \\
\text { charge, } \\
\text { instan- } \\
\text { taneous } \\
\text { (cubic } \\
\text { feet } \\
\text { per } \\
\text { second) } \\
(00061)\end{array}$ & $\begin{array}{c}\text { Arsenic, } \\
\text { dis- } \\
\text { solved } \\
(\mu \mathrm{g} / \mathrm{L} \\
\text { as As) } \\
(01000)\end{array}$ & $\begin{array}{l}\text { Cadmium, } \\
\text { dis- } \\
\text { solved } \\
\text { ( } \mu \mathrm{g} / \mathrm{L} \\
\text { as Cd) } \\
(01025)\end{array}$ & $\begin{array}{c}\text { Chro- } \\
\text { mium, } \\
\text { dis- } \\
\text { solved } \\
(\mu \mathrm{g} / \mathrm{L} \\
\text { as Cr) } \\
(01030)\end{array}$ & $\begin{array}{c}\text { Copper, } \\
\text { dis - } \\
\text { solved } \\
(\mu \mathrm{g} / \mathrm{L} \\
\text { as } \mathrm{Cu}) \\
(01040)\end{array}$ \\
\hline \multirow[t]{2}{*}{$R-5$} & $08-02-90$ & 0900 & 0.16 & 1 & $<1.0$ & $<1$ & 2 \\
\hline & $11-16-90$ & 1300 & 0.87 & $<1$ & $<1.0$ & $<1$ & 1 \\
\hline \multirow[t]{3}{*}{$R-6$} & $04-27-90$ & 1700 & 630 & 1 & $<1.0$ & 2 & 1 \\
\hline & $07-30-90$ & 1630 & 370 & 1 & $<1.0$ & $<1$ & 2 \\
\hline & $11-14-90$ & 1100 & 1,100 & $<1$ & $<1.0$ & $<1$ & 2 \\
\hline \multirow[t]{2}{*}{$\mathrm{R}-7$} & $04-29-90$ & 1430 & 0.17 & $<1$ & $<1.0$ & 2 & 2 \\
\hline & $11-16-90$ & 1200 & 0.06 & $<1$ & $<1.0$ & 1 & $<1$ \\
\hline \multirow[t]{2}{*}{$R-8$} & $04-29-90$ & 1600 & -- & 1 & 1.0 & 1 & 1 \\
\hline & $08-03-90$ & 1500 & -- & 1 & $<1.0$ & $<1$ & 2 \\
\hline \multirow[t]{3}{*}{$R-9$} & $04-28-90$ & 2000 & 12 & 1 & 1.0 & 1 & 12 \\
\hline & $07-31-90$ & 1500 & 2.7 & 1 & $<1.0$ & $<1$ & 5 \\
\hline & $11-15-90$ & 0900 & 5.2 & 1 & $<1.0$ & $<1$ & 5 \\
\hline \multirow[t]{3}{*}{$R-10$} & $04-29-90$ & 1730 & - & 1 & $<1.0$ & 2 & 3 \\
\hline & $08-02-90$ & 1300 & -- & 1 & $<1.0$ & $<1$ & 4 \\
\hline & $12-02-90$ & 1300 & -- & $<1$ & $<1.0$ & $<1$ & 2 \\
\hline \multirow[t]{2}{*}{$\mathrm{R}-11$} & $\begin{array}{l}04-28-90 \\
07-31-90\end{array}$ & $\begin{array}{l}1700 \\
1000\end{array}$ & $\begin{array}{l}710 \\
190\end{array}$ & $\begin{array}{l}1 \\
1\end{array}$ & $\begin{array}{r}1.0 \\
<1.0\end{array}$ & $\begin{array}{l}<1 \\
<1\end{array}$ & $\begin{array}{l}2 \\
2\end{array}$ \\
\hline & $11-15-90$ & 1300 & 1,090 & $<1$ & $<1.0$ & $<1$ & 3 \\
\hline
\end{tabular}


Table 21.--Streamflow and concentrations of trace elements in water samples: spring, summer, and fall 1990--Continued

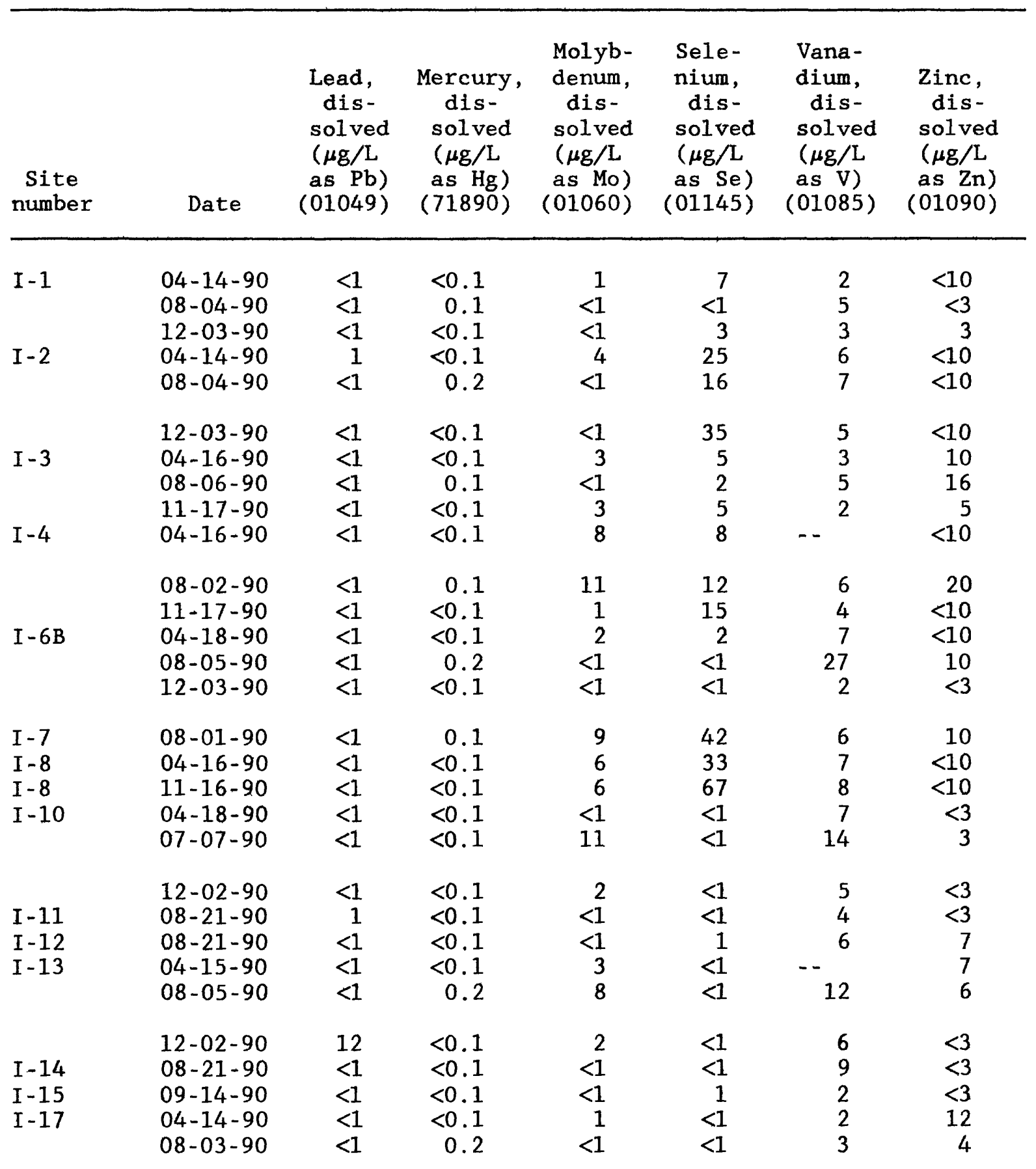


Table 21.--Streamflow and concentrations of trace elements in water samples: spring, summer, and fall 1990--Continued

\begin{tabular}{|c|c|c|c|c|c|c|c|}
\hline $\begin{array}{c}\text { Site } \\
\text { number }\end{array}$ & Date & $\begin{array}{c}\text { Lead, } \\
\text { dis- } \\
\text { solved } \\
(\mu \mathrm{g} / \mathrm{L} \\
\text { as } \mathrm{Pb}) \\
(01049)\end{array}$ & $\begin{array}{c}\text { Mercury, } \\
\text { dis - } \\
\text { solved } \\
(\mu \mathrm{g} / \mathrm{L} \\
\text { as } \mathrm{Hg}) \\
(71890)\end{array}$ & $\begin{array}{c}\text { Molyb- } \\
\text { denum, } \\
\text { dis- } \\
\text { solved } \\
(\mu \mathrm{g} / \mathrm{L} \\
\text { as Mo) } \\
(01060)\end{array}$ & $\begin{array}{c}\text { Sele- } \\
\text { nium, } \\
\text { dis- } \\
\text { solved } \\
(\mu \mathrm{g} / \mathrm{L} \\
\text { as Se) } \\
(01145)\end{array}$ & $\begin{array}{c}\text { Vana- } \\
\text { dium, } \\
\text { dis- } \\
\text { solved } \\
(\mu \mathrm{g} / \mathrm{L} \\
\text { as V) } \\
(01085)\end{array}$ & $\begin{array}{c}\text { Zinc, } \\
\text { dis- } \\
\text { solved } \\
(\mu g / L \\
\text { as } \mathrm{Zn}) \\
(01090)\end{array}$ \\
\hline $\begin{array}{l}I-17 \\
I-18 \\
I-20\end{array}$ & $\begin{array}{l}12-04-90 \\
12-04-90 \\
04-13-90 \\
08-04-90 \\
12-03-90\end{array}$ & $\begin{array}{r}<1 \\
<10 \\
<1 \\
<1 \\
<1\end{array}$ & $\begin{array}{r}<0.1 \\
<0.1 \\
<0.1 \\
0.2 \\
<0.1\end{array}$ & $\begin{array}{r}5 \\
15 \\
2 \\
<1 \\
<1\end{array}$ & $\begin{array}{r}1 \\
<1 \\
2 \\
3 \\
6\end{array}$ & $\begin{array}{r}1 \\
16 \\
4 \\
1 \\
1\end{array}$ & $\begin{array}{r}<3 \\
<10 \\
<3 \\
5 \\
10\end{array}$ \\
\hline $\begin{array}{l}I-21 \\
I-22\end{array}$ & $\begin{array}{l}04-17-90 \\
08-01-90 \\
11-16-90 \\
04-17-90 \\
08-01-90\end{array}$ & $\begin{array}{l}<1 \\
<1 \\
<1 \\
<1 \\
<1\end{array}$ & $\begin{array}{r}<0.1 \\
0.2 \\
0.1 \\
<0.1 \\
0.1\end{array}$ & $\begin{array}{l}8 \\
1 \\
9 \\
6 \\
2\end{array}$ & $\begin{array}{l}<1 \\
<1 \\
<1 \\
21 \\
11\end{array}$ & $\begin{array}{r}-- \\
3 \\
6 \\
2 \\
2\end{array}$ & $\begin{array}{r}<10 \\
15 \\
10 \\
<10 \\
10\end{array}$ \\
\hline $\begin{array}{l}I-22 B \\
I-23\end{array}$ & $\begin{array}{l}11-16-90 \\
09-14-90 \\
06-20-90 \\
08-02-90 \\
12-02-90\end{array}$ & $\begin{array}{r}<1 \\
1 \\
<1 \\
<1 \\
<1\end{array}$ & $\begin{array}{r}<0.1 \\
<0.1 \\
<0.1 \\
0.2 \\
<0.1\end{array}$ & $\begin{array}{r}6 \\
<1 \\
2 \\
1 \\
2\end{array}$ & $\begin{array}{r}12 \\
9 \\
<1 \\
<1 \\
<1\end{array}$ & $\begin{array}{l}2 \\
4 \\
1 \\
1 \\
1\end{array}$ & $\begin{array}{r}10 \\
8 \\
5 \\
13 \\
<10\end{array}$ \\
\hline $\begin{array}{l}I-24 \\
R-1\end{array}$ & $\begin{array}{l}04-17-90 \\
08-02-90 \\
12-02-90 \\
04-26-90 \\
07-30-90\end{array}$ & $\begin{array}{l}<1 \\
<1 \\
<1 \\
<1 \\
<1\end{array}$ & $\begin{array}{r}<0.1 \\
0.2 \\
<0.1 \\
<0.1 \\
0.1\end{array}$ & $\begin{array}{r}4 \\
2 \\
<1 \\
6 \\
<1\end{array}$ & $\begin{array}{r}2 \\
2 \\
3 \\
<1 \\
<1\end{array}$ & $\begin{array}{r}1 \\
<1 \\
1 \\
1 \\
2\end{array}$ & $\begin{array}{l}7 \\
8 \\
7 \\
8 \\
5\end{array}$ \\
\hline $\begin{array}{l}R-2 \\
R-3\end{array}$ & $\begin{array}{l}11-13-90 \\
04-27-90 \\
07-30-90 \\
11-13-90 \\
04-27-90\end{array}$ & $\begin{array}{l}<1 \\
<1 \\
<1 \\
<1 \\
<1\end{array}$ & $\begin{array}{l}<0.1 \\
<0.1 \\
<0.1 \\
<0.1 \\
<0.1\end{array}$ & $\begin{array}{r}1 \\
4 \\
<1 \\
<1 \\
1\end{array}$ & $\begin{array}{l}<1 \\
<1 \\
<1 \\
<1 \\
<1\end{array}$ & $\begin{array}{r}2 \\
<1 \\
2 \\
2 \\
<1\end{array}$ & $\begin{array}{r}4 \\
<3 \\
7 \\
5 \\
6\end{array}$ \\
\hline $\begin{array}{l}R-4 \\
R-5\end{array}$ & $\begin{array}{l}07-30-90 \\
11-14-90 \\
04-30-90 \\
08-03-90 \\
04-28-90\end{array}$ & $\begin{array}{l}<1 \\
<1 \\
<1 \\
<1 \\
<1\end{array}$ & $\begin{array}{r}0.1 \\
<0.1 \\
<0.1 \\
<0.1 \\
<0.1\end{array}$ & $\begin{array}{r}<1 \\
1 \\
1 \\
<1 \\
2\end{array}$ & $\begin{array}{l}<1 \\
<1 \\
<1 \\
<1 \\
<1\end{array}$ & $\begin{array}{r}<1 \\
<1 \\
1 \\
1 \\
4\end{array}$ & $\begin{array}{r}10 \\
9 \\
7 \\
8 \\
<10\end{array}$ \\
\hline
\end{tabular}


Table 21.--Streamflow and concentrations of trace elements in water samples: spring, summer, and fall 1990--Continued

\begin{tabular}{|c|c|c|c|c|c|c|c|}
\hline $\begin{array}{c}\text { Site } \\
\text { number }\end{array}$ & Date & $\begin{array}{c}\text { Lead, } \\
\text { dis- } \\
\text { solved } \\
(\mu g / L \\
\text { as } \mathrm{Pb}) \\
(01049)\end{array}$ & $\begin{array}{c}\text { Mercury, } \\
\text { dis- } \\
\text { solved } \\
(\mu \mathrm{g} / \mathrm{L} \\
\text { as } \mathrm{Hg}) \\
(71890)\end{array}$ & $\begin{array}{l}\text { Molyb- } \\
\text { denum, } \\
\text { dis - } \\
\text { solved } \\
(\mu \mathrm{g} / \mathrm{L} \\
\text { as Mo) } \\
(01060)\end{array}$ & $\begin{array}{c}\text { Sele- } \\
\text { nium, } \\
\text { dis- } \\
\text { solved } \\
(\mu \mathrm{g} / \mathrm{L} \\
\text { as } \mathrm{Se}) \\
(01145)\end{array}$ & $\begin{array}{c}\text { Vana- } \\
\text { dium, } \\
\text { dis- } \\
\text { solved } \\
(\mu g / L \\
\text { as V) } \\
(01085)\end{array}$ & $\begin{array}{c}\text { Zinc, } \\
\text { dis- } \\
\text { solved } \\
(\mu \mathrm{g} / \mathrm{L} \\
\text { as } \mathrm{Zn}) \\
(01090)\end{array}$ \\
\hline \multirow[t]{2}{*}{$R-5$} & $08-02-90$ & $<1$ & 0.2 & $<1$ & $<1$ & 1 & 6 \\
\hline & $11-16-90$ & $<1$ & $<0.1$ & 2 & $<1$ & 1 & $<10$ \\
\hline \multirow[t]{3}{*}{$R-6$} & $04-27-90$ & $<1$ & $<0.1$ & 1 & $<1$ & $<1$ & 4 \\
\hline & $07-30-90$ & 1 & $<0.1$ & $<1$ & $<1$ & 2 & 10 \\
\hline & $11-14-90$ & $<1$ & $<0.1$ & 1 & $<1$ & $<1$ & 13 \\
\hline \multirow[t]{2}{*}{$\mathrm{R}-7$} & $04-29-90$ & $<1$ & $<0.1$ & 2 & 3 & 7 & $<10$ \\
\hline & $11-16-90$ & $<1$ & $<0.1$ & 2 & 2 & 9 & $<10$ \\
\hline \multirow[t]{2}{*}{$R-8$} & $04-29-90$ & $<1$ & $<0.1$ & 1 & $<1$ & 1 & 6 \\
\hline & $08-03-90$ & $<1$ & $<0.1$ & $<1$ & $<1$ & 1 & $<3$ \\
\hline \multirow[t]{3}{*}{$R-9$} & $04-28-90$ & $<1$ & $<0.1$ & 6 & 4 & 4 & 9 \\
\hline & $07-31-90$ & $<1$ & 0.2 & 4 & 2 & 3 & 7 \\
\hline & $11-15-90$ & $<1$ & $<0.1$ & 2 & 3 & 3 & $<3$ \\
\hline \multirow[t]{3}{*}{$R-10$} & $04-29-90$ & $<1$ & $<0.1$ & 1 & $<1$ & 1 & 4 \\
\hline & $08-02-90$ & $<1$ & 0.2 & 1 & 1 & 2 & 11 \\
\hline & $12-02-90$ & $<1$ & $<0.1$ & $<1$ & 1 & $<1$ & 3 \\
\hline \multirow[t]{3}{*}{$R-11$} & $04-28-90$ & $<1$ & $<0.1$ & 2 & $<1$ & 1 & 9 \\
\hline & $07-31-90$ & $<1$ & 0.2 & $<1$ & 2 & 2 & 9 \\
\hline & $11-15-90$ & $<1$ & $<0.1$ & 1 & $<1$ & 1 & 6 \\
\hline
\end{tabular}


Table 21.--Streamflow and concentrations of trace elements in water samples: spring, summer, and fall 1990--Continued

\begin{tabular}{|c|c|c|c|c|c|c|c|}
\hline $\begin{array}{c}\text { Site } \\
\text { number }\end{array}$ & Date & Time & $\begin{array}{l}\text { Dis- } \\
\text { charge, } \\
\text { instan- } \\
\text { taneous } \\
\text { (cubic } \\
\text { feet } \\
\text { per } \\
\text { second) } \\
(00061)\end{array}$ & $\begin{array}{l}\text { Arsenic, } \\
\text { dis- } \\
\text { solved } \\
(\mu \mathrm{g} / \mathrm{L} \\
\text { as As) } \\
(01000)\end{array}$ & $\begin{array}{l}\text { Cadmium, } \\
\text { dis - } \\
\text { solved } \\
\text { ( } \mu \mathrm{g} / \mathrm{L} \\
\text { as Cd) } \\
(01025)\end{array}$ & $\begin{array}{l}\text { Chro- } \\
\text { mium, } \\
\text { dis- } \\
\text { solved } \\
(\mu \mathrm{g} / \mathrm{L} \\
\text { as Cr) } \\
(01030)\end{array}$ & $\begin{array}{c}\text { Copper, } \\
\text { dis - } \\
\text { solved } \\
(\mu \mathrm{g} / \mathrm{L} \\
\text { as Cu) } \\
(01040)\end{array}$ \\
\hline
\end{tabular}

Quality assurance/quality control samples

\begin{tabular}{|c|c|c|c|c|c|c|}
\hline I -2 & $\begin{array}{l}12-03-90 \\
12-03-90\end{array}$ & $\begin{array}{l}1300 \\
1300\end{array}$ & $\begin{array}{l}0.25 \\
0.25\end{array}$ & $\begin{array}{l}<1 \\
<1\end{array}$ & $\begin{array}{l}<1.0 \\
<1.0\end{array}$ & $\begin{array}{l}<1 \\
<1\end{array}$ \\
\hline$I-3$ & $\begin{array}{l}08-06-90 \\
08-06-90\end{array}$ & $\begin{array}{l}1000 \\
1010\end{array}$ & -- & $\begin{array}{l}3 \\
2\end{array}$ & $\begin{array}{l}<1.0 \\
<1.0\end{array}$ & $\begin{array}{l}<1 \\
<1\end{array}$ \\
\hline$I-4$ & $\begin{array}{l}11-17-90 \\
11-17-90\end{array}$ & $\begin{array}{l}1100 \\
1110\end{array}$ & $\begin{array}{l}-- \\
--\end{array}$ & $\begin{array}{l}<1 \\
<1\end{array}$ & $\begin{array}{l}<1.0 \\
<1.0\end{array}$ & $\begin{array}{r}1 \\
<1\end{array}$ \\
\hline$I-6 B$ & $\begin{array}{l}04-18-90 \\
04-18-90\end{array}$ & $\begin{array}{l}0930 \\
0940\end{array}$ & -- & $\begin{array}{l}<1 \\
<1\end{array}$ & $\begin{array}{l}<1.0 \\
<1.0\end{array}$ & $\begin{array}{l}2 \\
2\end{array}$ \\
\hline$I-7$ & $\begin{array}{l}08-01-90 \\
08-01-90\end{array}$ & $\begin{array}{l}0900 \\
0910\end{array}$ & $\begin{array}{l}0.38 \\
0.38\end{array}$ & $\begin{array}{l}<1 \\
<1\end{array}$ & $\begin{array}{l}<1.0 \\
<1.0\end{array}$ & $\begin{array}{r}<1 \\
1\end{array}$ \\
\hline $\mathrm{I}-17$ & $\begin{array}{l}08-03-90 \\
08-03-90\end{array}$ & $\begin{array}{l}1000 \\
1000\end{array}$ & $\begin{array}{l}-- \\
--\end{array}$ & $\begin{array}{l}1 \\
1\end{array}$ & $\begin{array}{l}<1.0 \\
<1.0\end{array}$ & $\begin{array}{l}<1 \\
<1\end{array}$ \\
\hline$I-22$ & $\begin{array}{l}11-16-90 \\
11-16-90\end{array}$ & $\begin{array}{l}1000 \\
1010\end{array}$ & $\begin{array}{l}0.08 \\
0.08\end{array}$ & $\begin{array}{l}<1 \\
<1\end{array}$ & $\begin{array}{l}<1.0 \\
<1.0\end{array}$ & $\begin{array}{l}<1 \\
<1\end{array}$ \\
\hline$R-2$ & $\begin{array}{l}04-27-90 \\
04-27-90\end{array}$ & $\begin{array}{l}0930 \\
0930\end{array}$ & $\begin{array}{l}450 \\
450\end{array}$ & $\begin{array}{l}<1 \\
<1\end{array}$ & $\begin{array}{l}<1.0 \\
<1.0\end{array}$ & $\begin{array}{l}1 \\
1\end{array}$ \\
\hline$R-4$ & $\begin{array}{l}04-30-90 \\
04-30-90\end{array}$ & $\begin{array}{l}1000 \\
1005\end{array}$ & -- & $\begin{array}{l}<1 \\
<1\end{array}$ & $\begin{array}{l}<1.0 \\
<1.0\end{array}$ & $\begin{array}{r}1 \\
<1\end{array}$ \\
\hline $\begin{array}{l}\text { Trip blank } \\
\text { Equipment } \\
\text { blank }\end{array}$ & $\begin{array}{l}08-05-90 \\
08-05-90\end{array}$ & 1500 & -- & $\begin{array}{l}<1 \\
<1\end{array}$ & $\begin{array}{l}<1.0 \\
<1.0\end{array}$ & $\begin{array}{l}<1 \\
<1\end{array}$ \\
\hline $\begin{array}{l}\text { Trip blank } \\
\text { Equipment } \\
\text { blank }\end{array}$ & $\begin{array}{l}12-03-90 \\
12-03-90\end{array}$ & 1430 & -- & 4 & $\begin{array}{l}<1.0 \\
<1.0\end{array}$ & $<1$ \\
\hline
\end{tabular}


Table 21.--Streamflow and concentrations of trace elements in water samples: spring, summer, and fall 1990--Concluded

\begin{tabular}{|c|c|c|c|c|c|c|c|}
\hline $\begin{array}{l}\text { Site } \\
\text { number }\end{array}$ & Date & $\begin{array}{c}\text { Lead, } \\
\text { dis- } \\
\text { solved } \\
(\mu g / \mathrm{L} \\
\text { as } \mathrm{Pb}) \\
(01049)\end{array}$ & $\begin{array}{c}\text { Mercury, } \\
\text { dis- } \\
\text { solved } \\
(\mu \mathrm{g} / \mathrm{L} \\
\text { as } \mathrm{Hg}) \\
(71890)\end{array}$ & $\begin{array}{l}\text { Molyb- } \\
\text { denum, } \\
\text { dis- } \\
\text { solved } \\
(\mu g / L \\
\text { as Mo) } \\
(01060)\end{array}$ & $\begin{array}{c}\text { Sele- } \\
\text { nium, } \\
\text { dis- } \\
\text { solved } \\
(\mu g / L \\
\text { as } S e) \\
(01145)\end{array}$ & $\begin{array}{l}\text { Vana- } \\
\text { dium, } \\
\text { dis- } \\
\text { solved } \\
(\mu g / L \\
\text { as V) } \\
(01085)\end{array}$ & $\begin{array}{c}\text { Zinc, } \\
\text { dis- } \\
\text { solved } \\
(\mu \mathrm{g} / \mathrm{L} \\
\text { as } \mathrm{Zn}) \\
(01090)\end{array}$ \\
\hline & Quality & \multicolumn{2}{|c|}{ y assurance/quality } & y control & samples & & \\
\hline$I-2$ & $\begin{array}{l}12-03-90 \\
12-03-90\end{array}$ & $\begin{array}{l}<1 \\
<1\end{array}$ & $\begin{array}{l}<0.1 \\
<0.1\end{array}$ & $\begin{array}{l}<1 \\
<1\end{array}$ & $\begin{array}{l}35 \\
34\end{array}$ & $\begin{array}{l}5 \\
5\end{array}$ & $\begin{array}{r}<10 \\
10\end{array}$ \\
\hline$I-3$ & $\begin{array}{l}08-06-90 \\
08-06-90\end{array}$ & $\begin{array}{l}<1 \\
<1\end{array}$ & $\begin{array}{l}0.1 \\
0.2\end{array}$ & $\begin{array}{l}<1 \\
<1\end{array}$ & $\begin{array}{l}2 \\
2\end{array}$ & $\begin{array}{l}5 \\
5\end{array}$ & $\begin{array}{r}16 \\
4\end{array}$ \\
\hline$I-4$ & $\begin{array}{l}11-17-90 \\
11-17-90\end{array}$ & $\begin{array}{l}<1 \\
<1\end{array}$ & $\begin{array}{l}<0.1 \\
<0.1\end{array}$ & $\begin{array}{l}1 \\
7\end{array}$ & $\begin{array}{l}15 \\
15\end{array}$ & $\begin{array}{l}4 \\
4\end{array}$ & $\begin{array}{r}<10 \\
10\end{array}$ \\
\hline$I-6 B$ & $\begin{array}{l}04-18-90 \\
04-18-90\end{array}$ & $\begin{array}{l}<1 \\
<1\end{array}$ & $\begin{array}{l}<0.1 \\
<0.1\end{array}$ & $\begin{array}{l}2 \\
1\end{array}$ & $\begin{array}{l}2 \\
2\end{array}$ & $\begin{array}{r}7 \\
10\end{array}$ & $\begin{array}{l}<10 \\
<10\end{array}$ \\
\hline I - 7 & $\begin{array}{l}08-01-90 \\
08-01-90\end{array}$ & $\begin{array}{l}<1 \\
<1\end{array}$ & $\begin{array}{l}0.1 \\
0.1\end{array}$ & $\begin{array}{l}9 \\
8\end{array}$ & $\begin{array}{l}42 \\
42\end{array}$ & $\begin{array}{l}6 \\
6\end{array}$ & $\begin{array}{l}10 \\
10\end{array}$ \\
\hline$I-17$ & $\begin{array}{l}08-03-90 \\
08-03-90\end{array}$ & $\begin{array}{l}<1 \\
<1\end{array}$ & $\begin{array}{l}0.2 \\
0.2\end{array}$ & $\begin{array}{l}<1 \\
<1\end{array}$ & $\begin{array}{l}<1 \\
<1\end{array}$ & $\begin{array}{l}3 \\
3\end{array}$ & $\begin{array}{r}4 \\
<3\end{array}$ \\
\hline$I-22$ & $\begin{array}{l}11-16-90 \\
11-16-90\end{array}$ & $\begin{array}{l}<1 \\
<1\end{array}$ & $\begin{array}{l}<0.1 \\
<0.1\end{array}$ & $\begin{array}{l}6 \\
2\end{array}$ & $\begin{array}{l}12 \\
17\end{array}$ & $\begin{array}{l}2 \\
1\end{array}$ & $\begin{array}{r}10 \\
<10\end{array}$ \\
\hline$R-2$ & $\begin{array}{l}04-27-90 \\
04-27-90\end{array}$ & $\begin{array}{l}<1 \\
<1\end{array}$ & $\begin{array}{l}<0.1 \\
<0.1\end{array}$ & $\begin{array}{l}4 \\
1\end{array}$ & $\begin{array}{l}<1 \\
<1\end{array}$ & $\begin{array}{r}<1 \\
2\end{array}$ & $\begin{array}{r}<3 \\
6\end{array}$ \\
\hline$R-4$ & $\begin{array}{l}04-30-90 \\
04-30-90\end{array}$ & $\begin{array}{l}<1 \\
<1\end{array}$ & $\begin{array}{l}<0.1 \\
<0.1\end{array}$ & $\begin{array}{l}1 \\
1\end{array}$ & $\begin{array}{l}<1 \\
<1\end{array}$ & $\begin{array}{l}1 \\
1\end{array}$ & $\begin{array}{r}7 \\
<3\end{array}$ \\
\hline $\begin{array}{l}\text { Trip blank } \\
\text { Equipment blank }\end{array}$ & $\begin{array}{l}08-05-90 \\
08-05-90\end{array}$ & $\begin{array}{l}<1 \\
<1\end{array}$ & $\begin{array}{l}0.1 \\
0.1\end{array}$ & $\begin{array}{l}<1 \\
<1\end{array}$ & $\begin{array}{l}<1 \\
<1\end{array}$ & $\begin{array}{l}<1 \\
<1\end{array}$ & $\begin{array}{l}12 \\
11\end{array}$ \\
\hline $\begin{array}{l}\text { Trip blank } \\
\text { Equipment blank }\end{array}$ & $\begin{array}{l}12-03-90 \\
12-03-90\end{array}$ & $\begin{array}{l}<1 \\
<1\end{array}$ & $\begin{array}{l}<0.1 \\
<0.1\end{array}$ & $\begin{array}{l}<1 \\
<1\end{array}$ & $\begin{array}{l}<1 \\
<1\end{array}$ & $\begin{array}{l}8 \\
8\end{array}$ & $\begin{array}{l}9 \\
5\end{array}$ \\
\hline
\end{tabular}


Table 22.-Concentrations of selected constituents in bottom sediment: fall 1990

[Site number, see figs. 7 and 8, tables 3 and 4;

ppm, parts per million; \%, percent; $<$, less than]

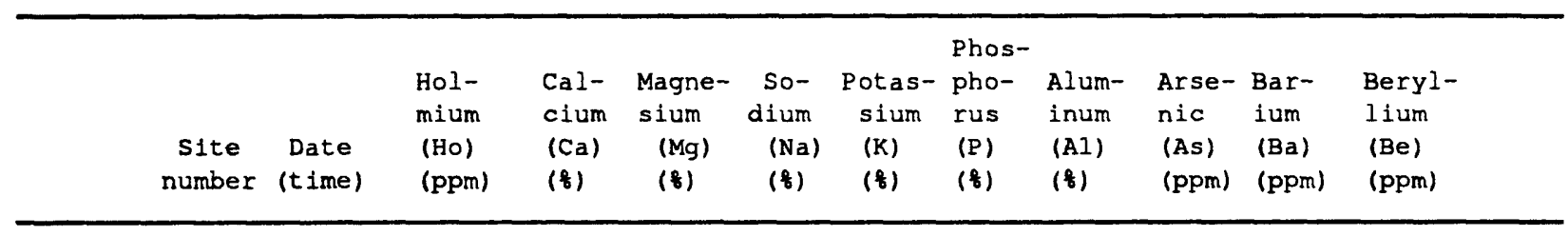

Less than 0.062 millimeter size fraction

\begin{tabular}{|c|c|c|c|c|c|c|c|c|c|c|}
\hline$I-1$ & $\begin{array}{l}12-03-90 \\
(1000)\end{array}$ & $<4$ & 3.9 & 0.59 & 0.87 & 1.7 & 0.07 & 5.1 & 3.6 & 700 \\
\hline$I-2$ & $\begin{array}{l}11-07-90 \\
(1600)\end{array}$ & $<4$ & 14 & 0.62 & 0.67 & 1.2 & 0.08 & 4.3 & 2.1 & 490 \\
\hline$I-3$ & $\begin{array}{l}11-09-90 \\
(1300)\end{array}$ & $<4$ & 8.9 & 1.1 & 0.47 & 1.5 & 0.07 & 7.1 & 5.1 & 690 \\
\hline$I-4$ & $\begin{array}{l}12-03-90 \\
(1600)\end{array}$ & $<4$ & 1.3 & 0.32 & 1.2 & 2.0 & 0.06 & 4.9 & 4.9 & 1,800 \\
\hline$I-6 A$ & $\begin{array}{l}11-08-90 \\
(1600)\end{array}$ & $<4$ & 5.9 & 1.0 & 0.68 & 1.6 & 0.06 & 7.8 & 4.9 & 900 \\
\hline$I-7$ & $\begin{array}{l}11-08-90 \\
(1000)\end{array}$ & $<4$ & 4.5 & 0.90 & 1.6 & 1.7 & 0.06 & 7.4 & 2.5 & 980 \\
\hline$I-17$ & $\begin{array}{l}11-07-90 \\
(1000)\end{array}$ & $<4$ & 1.7 & 0.66 & 1.1 & 2.2 & 0.07 & 6.2 & 2.6 & 790 \\
\hline$I-20$ & $\begin{array}{l}11-07-90 \\
(1300)\end{array}$ & $<4$ & 7.1 & 0.75 & 0.78 & 1.9 & 0.07 & 5.9 & 2.6 & 650 \\
\hline$I-21$ & $\begin{array}{l}11-06-90 \\
(0900)\end{array}$ & $<4$ & 5.1 & 0.94 & 1.0 & 1.7 & 0.06 & 7.2 & 3.6 & 550 \\
\hline$I-22$ & $\begin{array}{l}11-06-90 \\
(1600)\end{array}$ & $<4$ & 5.3 & 1.4 & 0.58 & 1.7 & 0.08 & 6.7 & 3.5 & 520 \\
\hline$I-23$ & $\begin{array}{l}11-06-90 \\
(1400)\end{array}$ & $<4$ & 7.3 & 1.1 & 0.58 & 1.7 & 0.06 & 7.1 & 4.5 & 430 \\
\hline$I-24$ & $\begin{array}{l}12-02-90 \\
(1030)\end{array}$ & $<4$ & 6.3 & 0.93 & 0.74 & 1.7 & 0.06 & 6.2 & 3.8 & 500 \\
\hline$R-1$ & $\begin{array}{l}11-13-90 \\
(1000)\end{array}$ & $<4$ & 0.78 & 0.47 & 1.4 & 2.2 & 0.04 & 5.9 & 3.0 & 830 \\
\hline$R-2$ & $\begin{array}{l}11-13-90 \\
(1400)\end{array}$ & $<4$ & 0.79 & 0.36 & 1.2 & 2.1 & 0.04 & 5.0 & 2.9 & 1,500 \\
\hline$R-5$ & $\begin{array}{l}11-16-90 \\
(1300)\end{array}$ & $<4$ & 1.4 & 0.65 & 1.3 & 2.1 & 0.07 & 7.4 & 4.6 & 810 \\
\hline$R-6$ & $\begin{array}{l}11-14-90 \\
(1100)\end{array}$ & $<4$ & 1.2 & 0.51 & 1.3 & 2.3 & 0.05 & 6.2 & 3.3 & 970 \\
\hline$R-9$ & $\begin{array}{l}11-15-90 \\
(0900)\end{array}$ & $<4$ & 3.0 & 0.75 & 1.5 & 1.8 & 0.06 & 5.7 & $4 \cdot 6$ & 1,600 \\
\hline $\mathrm{R}-11$ & $\begin{array}{l}11-15-90 \\
(1300)\end{array}$ & $<4$ & 1.7 & 0.59 & 1.3 & 2.1 & 0.06 & 5.4 & 3.0 & 940 \\
\hline
\end{tabular}

Quality assurance/quality control samples

$\begin{array}{llllllllllll}I-1 & \begin{array}{l}12-03-90 \\ (1010)\end{array} & <4 & 4.5 & 0.79 & 0.74 & 1.7 & 0.08 & 6.1 & 3.8 & 720 & 1 \\ I-7 & \begin{array}{l}11-08-90 \\ (1000)\end{array} & <4 & 4.4 & 0.91 & 1.6 & 1.7 & 0.06 & 7.4 & 2.7 & 950 & 2\end{array}$


Table 22.-Concentrations of selected constituents in bottom sediment: fall 1990-Continued

\begin{tabular}{|c|c|c|c|c|c|c|c|c|c|c|}
\hline $\begin{array}{l}\text { site } \\
\text { number }\end{array}$ & $\begin{array}{l}\text { Bis- } \\
\text { muth } \\
\text { (Bi) } \\
\text { (ppm) }\end{array}$ & $\begin{array}{l}\text { Cad- } \\
\text { mium } \\
\text { (Cd) } \\
\text { (ppm) }\end{array}$ & $\begin{array}{l}\text { Ce- } \\
\text { rium } \\
\text { (Ce) } \\
\text { (ppm) }\end{array}$ & $\begin{array}{l}\text { Chro- } \\
\text { mium } \\
\text { (Cr) } \\
\text { (ppm) }\end{array}$ & $\begin{array}{l}\text { Co- } \\
\text { balt } \\
(\mathrm{Co}) \\
(\mathrm{ppm})\end{array}$ & $\begin{array}{l}\text { Cop- } \\
\text { per } \\
\text { (Cu) } \\
\text { (ppm) }\end{array}$ & $\begin{array}{l}\text { Euro- } \\
\text { pium } \\
\text { (Eu) } \\
\text { (ppm) }\end{array}$ & $\begin{array}{l}\text { Gal- } \\
\text { lium } \\
\text { (Ga) } \\
\text { (ppm) }\end{array}$ & $\begin{array}{l}\text { Gold } \\
(\mathrm{Au}) \\
(\mathrm{ppm})\end{array}$ & $\begin{array}{l}\text { Iron } \\
\text { (Fe) } \\
(z)\end{array}$ \\
\hline \multicolumn{11}{|c|}{ Less than 0} \\
\hline$I-1$ & $<10$ & $<2$ & 76 & 30 & 8 & 17 & $<2$ & 11 & $<8$ & 1.9 \\
\hline$I-2$ & $<10$ & $<2$ & 54 & 24 & 8 & 13 & $<2$ & 12 & $<8$ & 1.9 \\
\hline$I-3$ & $<10$ & $<2$ & 78 & 33 & 12 & 20 & $<2$ & 17 & $<8$ & 2.7 \\
\hline$I-4$ & $<10$ & $<2$ & 220 & 51 & 10 & 18 & $<2$ & 11 & $<8$ & 2.7 \\
\hline$I-6 \mathrm{~A}$ & $<10$ & $<2$ & 91 & 33 & 12 & 22 & $<2$ & 19 & $<8$ & 2.9 \\
\hline$I-7$ & $<10$ & $<2$ & 86 & 24 & 12 & 27 & $<2$ & 18 & $<8$ & 2.9 \\
\hline$I-17$ & $<10$ & $<2$ & 96 & 29 & 10 & 20 & $<2$ & 16 & $<8$ & 2.4 \\
\hline$I-20$ & $<10$ & $<2$ & 84 & 28 & 9 & 31 & $<2$ & 15 & $<8$ & 2.3 \\
\hline$I-21$ & $<10$ & $<2$ & 78 & 34 & 12 & 36 & $<2$ & 19 & $<8$ & 3.3 \\
\hline$I-22$ & $<10$ & $<2$ & 72 & 53 & 11 & 29 & $<2$ & 17 & $<8$ & 2.8 \\
\hline$I-23$ & $<10$ & $<2$ & 77 & 45 & 11 & 34 & $<2$ & 18 & $<8$ & 3.0 \\
\hline$I-24$ & $<10$ & $<2$ & 72 & 37 & 10 & 27 & $<2$ & 15 & $<8$ & 2.9 \\
\hline$R-1$ & $<10$ & $<2$ & 76 & 28 & 9 & 27 & $<2$ & 14 & $<8$ & 2.1 \\
\hline$R-2$ & $<10$ & $<2$ & 200 & 43 & 9 & 15 & $<2$ & 12 & $<8$ & 2.8 \\
\hline$R-5$ & $<10$ & $<2$ & 88 & 31 & 11 & 28 & $<2$ & 18 & $<8$ & 2.8 \\
\hline$R-6$ & $<10$ & $<2$ & 93 & 29 & 9 & 21 & $<2$ & 14 & $<8$ & 2.3 \\
\hline$R-9$ & $<10$ & $<2$ & 96 & 31 & 10 & 18 & $<2$ & 14 & $<8$ & 2.3 \\
\hline$R-11$ & $<10$ & $<2$ & 98 & 30 & 8 & 19 & $<2$ & 11 & $<8$ & 2.0 \\
\hline \multicolumn{11}{|c|}{ Quality assurance/quality control samples } \\
\hline$I-1$ & $<10$ & $<2$ & 77 & 23 & 10 & 20 & $<2$ & 14 & $<8$ & 2.4 \\
\hline$I-7$ & $<10$ & $<2$ & 83 & 24 & 12 & 27 & $<2$ & 17 & $<8$ & 2.9 \\
\hline
\end{tabular}


Table 22.-Concentrations of selected constituents in bottom sediment: fall 1990--Continued

\begin{tabular}{|c|c|c|c|c|c|c|c|c|c|c|c|}
\hline $\begin{array}{l}\text { site } \\
\text { num- } \\
\text { ber }\end{array}$ & $\begin{array}{l}\text { Lan- } \\
\text { tha- } \\
\text { num } \\
\text { (La) } \\
\text { (ppm) }\end{array}$ & $\begin{array}{l}\text { Lead } \\
(\mathrm{Pb}) \\
(\mathrm{Ppm})\end{array}$ & $\begin{array}{l}\text { Lith- } \\
\text { Ium } \\
\text { (L1) } \\
\text { (ppm) }\end{array}$ & $\begin{array}{l}\text { Manga- } \\
\text { nese } \\
(\mathrm{Mn}) \\
(\mathrm{ppm})\end{array}$ & $\begin{array}{l}\text { - Mer- } \\
\text { cury } \\
\text { (Hg) } \\
\text { (ppm) }\end{array}$ & $\begin{array}{l}\text { Molyb- } \\
\text { denum } \\
\text { (Mo) } \\
\text { (ppm) }\end{array}$ & $\begin{array}{l}\text { Neo- } \\
\text { dym- } \\
\text { lum } \\
\text { (Nd) } \\
\text { (ppm) }\end{array}$ & $\begin{array}{l}\text { N1ck- } \\
\text { el } \\
\text { (N1) } \\
\text { (ppm) }\end{array}$ & $\begin{array}{l}\text { Nio- } \\
\text { bium } \\
(\mathrm{Nb}) \\
\text { (ppm) }\end{array}$ & $\begin{array}{l}\text { Scan- } \\
\text { dium } \\
\text { (Sc) } \\
\text { (ppm) }\end{array}$ & $\begin{array}{l}\text { Sele- } \\
\text { nium } \\
\text { (Se) } \\
\text { (ppm }\end{array}$ \\
\hline \multicolumn{12}{|c|}{ Less than $0.062 \mathrm{mill}$ imeter size fraction } \\
\hline$I-1$ & 40 & 15 & 21 & 790 & 0.02 & $<2$ & 31 & 12 & 5 & 6 & 0.8 \\
\hline$I-2$ & 29 & 15 & 21 & 1,300 & 0.02 & 3 & 25 & 10 & 4 & 6 & 37 \\
\hline$I-3$ & 42 & 18 & 28 & 830 & 0.04 & 2 & 34 & 16 & 7 & 9 & 1.9 \\
\hline$I-4$ & 110 & 18 & 16 & 740 & 0.02 & $<2$ & 91 & 12 & $<4$ & 7 & 0.3 \\
\hline$I-6 A$ & 50 & 20 & 26 & 580 & 0.04 & $<2$ & 40 & 14 & 6 & 10 & 1.5 \\
\hline$I-7$ & 45 & 19 & 22 & 500 & 0.02 & $<2$ & 37 & 12 & 7 & 9 & 5.0 \\
\hline$I-17$ & 52 & 18 & 21 & 1,200 & 0.02 & $<2$ & 41 & 12 & 9 & 7 & 0.5 \\
\hline$I-20$ & 46 & 17 & 21 & 450 & $<.02$ & $<2$ & 36 & 11 & $<4$ & 7 & 1.6 \\
\hline$I-21$ & 43 & 25 & 26 & 930 & 0.04 & $<2$ & 36 & 14 & 9 & 10 & 0.5 \\
\hline$I-22$ & 40 & 24 & 36 & 830 & 0.04 & $<2$ & 34 & 20 & 6 & 10 & 6.0 \\
\hline$I-23$ & 43 & 44 & 35 & 890 & 0.04 & $<2$ & 34 & 16 & 11 & 10 & 4.5 \\
\hline$I-24$ & 40 & 32 & 27 & 480 & 0.02 & $<2$ & 33 & 16 & 8 & 8 & 5.5 \\
\hline R-1 & 40 & 15 & 20 & $660<$ & $<0.02$ & $<2$ & 34 & 12 & $<4$ & 6 & 0.1 \\
\hline$R-2$ & 110 & 20 & 17 & $580<$ & $<0.02$ & $<2$ & 88 & 10 & $<4$ & 7 & 0.1 \\
\hline$R-5$ & 49 & 19 & 21 & 390 & 0.02 & $<2$ & 40 & 13 & 9 & 8 & 0.3 \\
\hline$R-6$ & 50 & 25 & 20 & $580<$ & $<0.02$ & $<2$ & 42 & 11 & $<4$ & 7 & 0.2 \\
\hline$R-9$ & 52 & 16 & 19 & 630 & 0.02 & $<2$ & 44 & 10 & $<4$ & 6 & 0.4 \\
\hline R-11 & 52 & 20 & 19 & 460 & 0.02 & $<2$ & 44 & 10 & $<4$ & 6 & 0.3 \\
\hline \multicolumn{12}{|c|}{ Quality assurance/quality control samples } \\
\hline$I-1$ & 40 & 18 & 26 & 940 & 0.04 & $<2$ & 32 & 13 & 6 & 8 & 1.0 \\
\hline$I-7$ & 44 & 16 & 22 & 500 & 0.02 & $<2$ & 36 & 11 & 8 & 9 & 5.1 \\
\hline
\end{tabular}




\section{Table 22.-Concentrations of selected constituents in bottom sediment: fall 1990--Continued}

\begin{tabular}{|c|c|c|c|c|c|c|c|c|c|c|c|}
\hline $\begin{array}{l}\text { site } \\
\text { num- } \\
\text { ber }\end{array}$ & $\begin{array}{l}\text { Silver } \\
\text { (Ag) } \\
\text { (ppm) }\end{array}$ & $\begin{array}{l}\text { Stron- } \\
\text { tium } \\
\text { (Sr) } \\
\text { (ppm) }\end{array}$ & $\begin{array}{l}\text { Tanta- } \\
\text { lium } \\
\text { (Ta) } \\
\text { (ppm) }\end{array}$ & $\begin{array}{l}\text { Tho- } \\
\text { rium } \\
\text { (Th) } \\
\text { (ppm) }\end{array}$ & $\begin{array}{l}\operatorname{Tin} \\
(\mathrm{Sn}) \\
(\mathrm{ppm})\end{array}$ & $\begin{array}{l}\text { Tita- } \\
\text { nium } \\
\text { (Ti) } \\
\text { (ppm) }\end{array}$ & $\begin{array}{l}\text { Vana- } \\
\text { dium } \\
\text { (V) } \\
\text { (ppm) }\end{array}$ & $\begin{array}{l}\text { Yt- } \\
\text { ter- } \\
\text { bium } \\
\text { (Yb) } \\
\text { (ppm) }\end{array}$ & $\begin{array}{l}\text { Yt- } \\
\text { trium } \\
\text { (Y) } \\
\text { (ppm) }\end{array}$ & $\begin{array}{l}\text { Zinc } \\
(2 n) \\
(p p m)\end{array}$ & $\begin{array}{l}\text { Ura- } \\
\text { nium } \\
\text { (U) } \\
\text { (ppm) }\end{array}$ \\
\hline
\end{tabular}

Less than 0.062 millimeter size fraction

\begin{tabular}{|c|c|c|c|c|c|c|c|c|c|c|c|}
\hline$I-1$ & $<2$ & 530 & $<40$ & 11 & $<5$ & 0.31 & 47 & 2 & 19 & 61 & $<100$ \\
\hline$I-2$ & $<2$ & 1,500 & $<40$ & 9 & $<5$ & 0.20 & 42 & 2 & 14 & 57 & $<100$ \\
\hline$I-3$ & $<2$ & 1,000 & $<40$ & 13 & $<5$ & 0.26 & 66 & 2 & 19 & 76 & $<100$ \\
\hline$I-4$ & $<2$ & 230 & $<40$ & 45 & $<5$ & 0.71 & 66 & 4 & 35 & 42 & $<100$ \\
\hline$I-6 A$ & $<2$ & 350 & $<40$ & 12 & $<5$ & 0.32 & 76 & 2 & 22 & 66 & $<100$ \\
\hline$I-7$ & $<2$ & 590 & $<40$ & 9 & $<5$ & 0.37 & 75 & 2 & 19 & 68 & $<100$ \\
\hline$I-17$ & $<2$ & 300 & $<40$ & 15 & $<5$ & 0.40 & 53 & 2 & 21 & 59 & $<100$ \\
\hline$I-20$ & $<2$ & 900 & $<40$ & 11 & $<5$ & 0.31 & 54 & 2 & 18 & 54 & $<100$ \\
\hline$I-21$ & $<2$ & 500 & $<40$ & 13 & $<5$ & 0.35 & 79 & 2 & 21 & 96 & $<100$ \\
\hline$I-22$ & $<2$ & 340 & $<40$ & 12 & $<5$ & 0.30 & 110 & 2 & 21 & 100 & $<100$ \\
\hline$I-23$ & $<2$ & 440 & $<40$ & 13 & $<5$ & 0.33 & 83 & 2 & 21 & 150 & $<100$ \\
\hline$I-24$ & $<2$ & 420 & $<40$ & 11 & $<5$ & 0.31 & 72 & 2 & 20 & 150 & $<100$ \\
\hline$R-1$ & $<2$ & 160 & $<40$ & 12 & $<5$ & 0.32 & 49 & 2 & 16 & 48 & $<100$ \\
\hline$R-2$ & $<2$ & 170 & $<40$ & 44 & $<5$ & 0.68 & 72 & 4 & 38 & 41 & $<100$ \\
\hline$R-5$ & $<2$ & 290 & $<40$ & 12 & $<5$ & 0.36 & 73 & 2 & 21 & 69 & $<100$ \\
\hline$R-6$ & $<2$ & 220 & $<40$ & 15 & $<5$ & 0.39 & 56 & 2 & 22 & 86 & $<100$ \\
\hline$R-9$ & $<2$ & 380 & $<40$ & 16 & $<5$ & 0.42 & 58 & 3 & 24 & 49 & $<100$ \\
\hline $\mathrm{R}-11$ & $<2$ & 230 & $<40$ & 18 & $<5$ & 0.39 & 54 & 3 & 24 & 65 & $<100$ \\
\hline & & Qualj & \multicolumn{3}{|c|}{ assurance/quality } & control & \multicolumn{2}{|c|}{ samples } & & & \\
\hline$I-1$ & $<2$ & 590 & $<40$ & 11 & $<5$ & 0.30 & 55 & 2 & 21 & 85 & $<100$ \\
\hline$I-7$ & $<2$ & 580 & $<40$ & 10 & $<5$ & 0.38 & 75 & 2 & 19 & 70 & $<100$ \\
\hline
\end{tabular}


Table 22.-Concentrations of selected constituents in bottom sediment: fall 1990--Continued

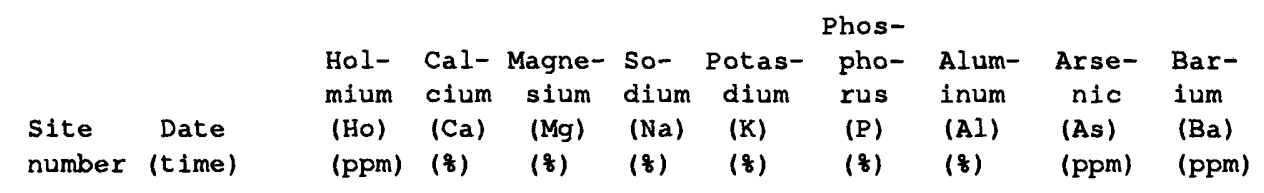

Less than 2 millimeter size fraction

\begin{tabular}{|c|c|c|c|c|c|c|c|c|c|c|}
\hline$I-1$ & $\begin{array}{l}12-03-90 \\
(1000)\end{array}$ & $<4$ & 1.1 & 0.19 & 1.0 & 2.3 & 0.03 & 4.1 & 2.6 & 830 \\
\hline$I-2$ & $\begin{array}{l}11-07-90 \\
(1600)\end{array}$ & $<4$ & 9.6 & 0.48 & 0.80 & 1.5 & 0.06 & 4.3 & 2.4 & 600 \\
\hline$I-3$ & $\begin{array}{l}11-09-90 \\
(1300)\end{array}$ & $<4$ & 5.8 & 0.87 & 0.57 & 1.8 & 0.06 & 6.4 & 4.1 & 740 \\
\hline$I-4$ & $\begin{array}{l}12-03-90 \\
(1600)\end{array}$ & $<4$ & 0.39 & 0.06 & 0.95 & 2.5 & 0.01 & 3.6 & 2.9 & 1,000 \\
\hline$I-6 A$ & $\begin{array}{l}11-08-90 \\
(1600)\end{array}$ & $<4$ & 5.4 & 1.0 & 0.76 & 1.8 & 0.06 & 8.1 & 4.7 & 890 \\
\hline$I-7$ & $\begin{array}{l}11-08-90 \\
(1000)\end{array}$ & $<4$ & 2.6 & 0.54 & 1.7 & 2.0 & 0.05 & 6.4 & 2.9 & 1,100 \\
\hline$I-17$ & $\begin{array}{l}11-07-90 \\
(1000)\end{array}$ & $<4$ & 0.70 & 0.28 & 1.1 & 2.5 & 0.03 & 4.7 & 1.5 & 850 \\
\hline$I-20$ & $\begin{array}{l}11-07-90 \\
(1300)\end{array}$ & $<4$ & 3.3 & 0.44 & 0.97 & 2.4 & 0.04 & 5.1 & 2.2 & 760 \\
\hline$I-21$ & $\begin{array}{l}11-06-90 \\
(0900)\end{array}$ & $<4$ & 3.7 & 0.79 & 1.1 & 1.9 & 0.05 & 6.7 & 3.4 & 610 \\
\hline$I-22$ & $\begin{array}{l}11-06-90 \\
(1600)\end{array}$ & $<4$ & 3.9 & 1.0 & 0.77 & 1.9 & 0.06 & 6.3 & 4.4 & 610 \\
\hline$I-23$ & $\begin{array}{l}11-06-90 \\
(1400)\end{array}$ & $<4$ & 6.5 & 1.0 & 0.59 & 1.8 & 0.06 & 7.0 & 2.6 & 430 \\
\hline$I-24$ & $\begin{array}{l}12-02-90 \\
(1030)\end{array}$ & $<4$ & 3.8 & 0.62 & 0.94 & 2.0 & 0.04 & 5.3 & 3.2 & 590 \\
\hline$R-1$ & $\begin{array}{l}11-13-90 \\
(1000)\end{array}$ & $<4$ & 0.23 & 0.07 & 1.1 & 2.8 & 0.01 & 3.9 & 2.6 & 880 \\
\hline$R-2$ & $\begin{array}{l}11-13-90 \\
(1400)\end{array}$ & $<4$ & 0.36 & 0.09 & 1.2 & 2.4 & 0.02 & 3.8 & 5.9 & 900 \\
\hline$R-5$ & $\begin{array}{l}11-16-90 \\
(1300)\end{array}$ & $<4$ & 1.0 & 0.32 & 1.4 & 2.5 & 0.03 & 5.9 & 3.4 & 1,000 \\
\hline$R-6$ & $\begin{array}{l}11-14-90 \\
(1100)\end{array}$ & $<4$ & 0.42 & 0.12 & 1.1 & 2.7 & 0.02 & 4.1 & 2.4 & 890 \\
\hline$R-9$ & $\begin{array}{l}11-15-90 \\
(0900)\end{array}$ & $<4$ & 1.2 & 0.15 & 1.3 & 2.0 & 0.02 & 4.2 & 4.1 & 1,100 \\
\hline$R-11$ & $\begin{array}{l}11-15-90 \\
(1300)\end{array}$ & $<4$ & 0.78 & 0.18 & 1.2 & 2.5 & 0.03 & 4.3 & 3.0 & 990 \\
\hline
\end{tabular}

Quality assurance/quality control samples

$\begin{array}{llllllllllll}I-1 & \begin{array}{l}12-03-90 \\ (1010)\end{array} & <4 & 1.7 & 0.36 & 0.98 & 2.2 & 0.04 & 4.8 & 3.0 & 800 \\ I-7 & \begin{array}{l}11-08-90 \\ (1000)\end{array} & <4 & 2.4 & 0.51 & 1.7 & 2.2 & 0.04 & 6.2 & 2.4 & 1.000\end{array}$


Table 22.-Concentrations of selected constituents in bottom sediment: fall 1990-Continued

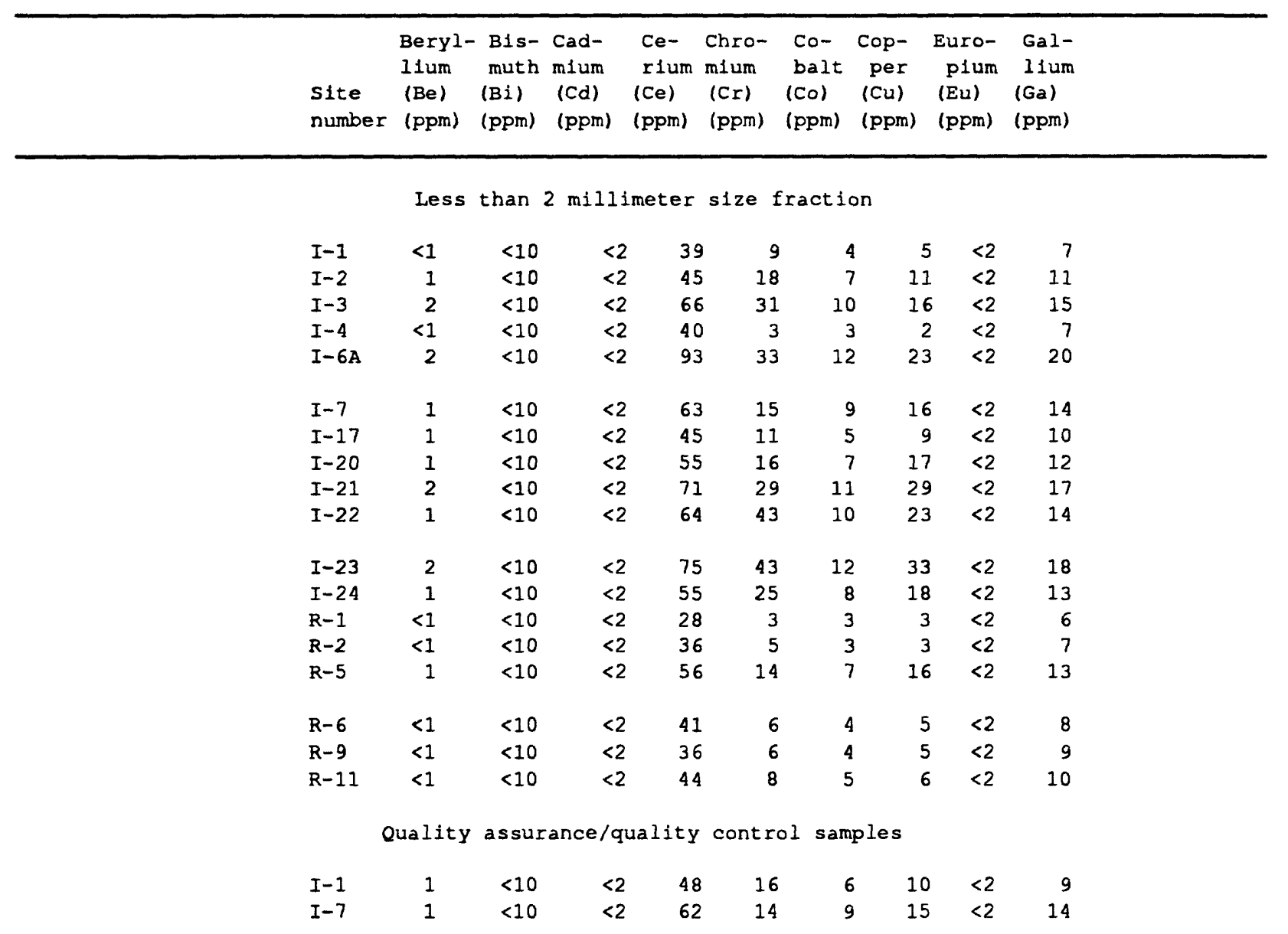


Table 22.-Concentrations of selected constituents in bottom sediment: fall 1990-Continued

\begin{tabular}{|c|c|c|c|c|c|c|c|c|c|c|c|}
\hline $\begin{array}{l}\text { Site } \\
\text { number }\end{array}$ & $\begin{array}{l}\text { Gold } \\
\text { (Au) } \\
\text { (ppm) }\end{array}$ & $\begin{array}{l}\text { Iron } \\
\text { (Fe) } \\
(8)\end{array}$ & $\begin{array}{l}\text { Lan- } \\
\text { tha- } \\
\text { num } \\
\text { (La) } \\
\text { (ppm) }\end{array}$ & $\begin{array}{l}\text { Lead } \\
(\mathrm{Pb}) \\
(\mathrm{ppm})\end{array}$ & $\begin{array}{l}\text { Lith- } \\
\text { ium } \\
\text { (Li) } \\
\text { (ppm) }\end{array}$ & $\begin{array}{l}\text { Manga- } \\
\text { nese } \\
(\mathrm{Mn}) \\
\text { (ppm) }\end{array}$ & $\begin{array}{l}\text { Mer- } \\
\text { cury } \\
\text { (Hg) } \\
\text { (ppm) }\end{array}$ & $\begin{array}{l}\text { Molyb- } \\
\text { denum } \\
\text { (Mo) } \\
\text { (ppm) }\end{array}$ & $\begin{array}{l}\text { Neo- } \\
\text { dym- } \\
\text { ium } \\
\text { (Nd) } \\
\text { (ppm) }\end{array}$ & $\begin{array}{l}\text { Nick- } \\
\text { el } \\
\text { (Ni) } \\
\text { (ppm) }\end{array}$ & $\begin{array}{l}\text { Nio- } \\
\text { bium } \\
\text { (Nb) } \\
\text { (ppm) }\end{array}$ \\
\hline
\end{tabular}

Less than 2 millimeter size fraction

$\begin{array}{lllllrlrrrrr}I-1 & <8 & 0.74 & 24 & 11 & 11 & 220 & 0.04 & <2 & 16 & 5 & <4 \\ I-2 & <8 & 1.5 & 26 & 12 & 17 & 910 & 0.04 & 3 & 21 & 8 & <4 \\ I-3 & <8 & 2.3 & 36 & 17 & 23 & 620 & 0.04 & <2 & 29 & 14 & <4 \\ I-4 & <8 & 0.46 & 23 & 12 & 6 & 200 & <0.02 & <2 & 17 & 2 & <4 \\ I-6 A & <8 & 2.9 & 52 & 19 & 27 & 550 & 0.04 & <2 & 41 & 14 & 8 \\ & & & & & & & & & & & \\ I-7 & <8 & 2.0 & 34 & 13 & 15 & 370 & <0.02 & <2 & 28 & 8 & <4 \\ I-17 & <8 & 1.0 & 25 & 13 & 11 & 450 & 0.04 & <2 & 19 & 6 & <4 \\ I-20 & <8 & 1.5 & 32 & 14 & 14 & 280 & 0.04 & <2 & 24 & 7 & 5 \\ I-21 & <8 & 2.8 & 40 & 22 & 23 & 690 & 0.04 & <2 & 31 & 13 & 8 \\ I-22 & <8 & 2.4 & 35 & 25 & 30 & 650 & 0.04 & 3 & 27 & 17 & 6 \\ & & & & & & & & & & & \\ I-23 & <8 & 2.8 & 42 & 39 & 33 & 810 & 0.10 & <2 & 36 & 16 & 9 \\ I-24 & <8 & 2.1 & 30 & 25 & 19 & 360 & 0.04 & <2 & 23 & 10 & 5 \\ R-1 & <8 & 0.43 & 17 & 15 & 6 & 220 & 0.04 & <2 & 9 & 3 & <4 \\ R-2 & <8 & 0.52 & 21 & 13 & 8 & 200 & 0.02 & <2 & 12 & 3 & <4 \\ R-5 & <8 & 1.7 & 33 & 12 & 12 & 280 & 0.02 & <2 & 28 & 7 & 5 \\ & & & & & & & & & & & \\ R-6 & <8 & 0.64 & 24 & 19 & 8 & 250 & 0.02 & <2 & 18 & 3 & <4 \\ R-9 & <8 & 1.1 & 21 & 11 & 8 & 340 & 0.06 & <2 & 16 & 4 & <4 \\ R-11 & <8 & 0.87 & 24 & 15 & 10 & 300 & 0.04 & <2 & 19 & 4 & <4\end{array}$

Quality assurance/quality control samples

$\begin{array}{llllllllllll}I-1 & <8 & 1.2 & 27 & 13 & 15 & 410 & 0.04 & <2 & 18 & 7 & <4 \\ I-7 & <8 & 1.9 & 34 & 15 & 15 & 370 & 0.02 & <2 & 26 & 7 & <4\end{array}$


Table 22.-Concentrations of selected constituents in bottom sediment: fall 1990-Concluded

\begin{tabular}{|c|c|c|c|c|c|c|c|c|c|c|c|c|c|}
\hline $\begin{array}{l}\text { Site } \\
\text { number }\end{array}$ & $\begin{array}{l}\text { Scan- } \\
\text { dium } \\
\text { (Sc) } \\
\text { (ppm) }\end{array}$ & $\begin{array}{c}\text { - Sele- } \\
\text { nium } \\
\text { (Se) } \\
\text { (ppm) }\end{array}$ & $\begin{array}{l}\text { Sil- } \\
\text { ver- } \\
\text { (Ag) } \\
\text { (ppm) }\end{array}$ & $\begin{array}{l}\text { Stron- } \\
\text { tium } \\
\text { (Sr) } \\
\text { (ppm) }\end{array}$ & $\begin{array}{l}\text { Tan- } \\
- \text { ta- } \\
\text { lium } \\
\text { (Ta) } \\
\text { (ppm) }\end{array}$ & $\begin{array}{l}\text { Tho- } \\
\text { rium } \\
\text { (Th) } \\
\text { (ppm) }\end{array}$ & $\begin{array}{l}\mathrm{Tin} \\
(\mathrm{Sn}) \\
\text { (ppm) }\end{array}$ & $\begin{array}{c}\text { Tita- } \\
\text { nium } \\
\text { (Ti) } \\
\text { (ppm) }\end{array}$ & $\begin{array}{c}\text { Vana- } \\
\text { dium } \\
\text { (V) } \\
\text { (ppm) }\end{array}$ & $\begin{array}{l}\text { Yt- } \\
\text { ter- } \\
\text { bium } \\
\text { (Yb) } \\
\text { (ppm) }\end{array}$ & $\begin{array}{c}\text { Yt- } \\
\text { trium } \\
(Y) \\
\text { (ppm) }\end{array}$ & $\begin{array}{l}\text { Zinc } \\
(\mathrm{Zn}) \\
(\mathrm{ppm})\end{array}$ & $\begin{array}{l}\text { Ura- } \\
\text { nium } \\
\text { (U) } \\
\text { (ppm) }\end{array}$ \\
\hline \multicolumn{14}{|c|}{ Less than 2 millimeter size fraction } \\
\hline$I-1$ & 2 & 0.3 & $<2$ & 240 & $<40$ & 6 & $<5$ & 0.11 & 18 & 1 & 9 & 23 & $<100$ \\
\hline$I-2$ & 5 & 29 & $<2$ & .000 & $<40$ & 6 & $<5$ & 0.16 & 34 & 1 & 11 & 43 & $<100$ \\
\hline$I-3$ & 8 & 1.5 & $<2$ & 660 & $<40$ & 10 & $<5$ & 0.22 & 54 & 2 & 16 & 64 & $<100$ \\
\hline$I-4$ & $<2$ & 0.1 & $<2$ & 140 & $<40$ & 6 & $<5$ & 0.07 & 8 & $<1$ & 6 & 9 & $<100$ \\
\hline$I-6 \mathrm{~A}$ & 11 & 1.4 & $<2$ & 340 & $<40$ & 13 & $<5$ & 0.32 & 77 & 2 & 22 & 69 & $<100$ \\
\hline $\mathrm{I}-7$ & 5 & 2.9 & $<2$ & 500 & $<40$ & 7 & $<5$ & 0.24 & 48 & 1 & 13 & 45 & $<100$ \\
\hline$I-17$ & 3 & 0.2 & $<2$ & 180 & $<40$ & 5 & $<5$ & 0.16 & 22 & $<1$ & 9 & 26 & $<100$ \\
\hline$I-20$ & 4 & 0.8 & $<2$ & 480 & $<40$ & 7 & $<5$ & 0.20 & 32 & 1 & 12 & 35 & $<100$ \\
\hline$I-21$ & 9 & 0.4 & $<2$ & 400 & $<40$ & 11 & $<5$ & 0.32 & 69 & 2 & 18 & 82 & $<100$ \\
\hline$I-22$ & 8 & 5.7 & $<2$ & 300 & $<40$ & 8 & $<5$ & 0.26 & 88 & 2 & 17 & 87 & $<100$ \\
\hline$I-23$ & 10 & 3.3 & $<2$ & 400 & $<40$ & 13 & $<5$ & 0.32 & 79 & 2 & 20 & 140 & $<100$ \\
\hline$I-24$ & 6 & 4.4 & $<2$ & 300 & $<40$ & 7 & $<5$ & 0.23 & 54 & 1 & 14 & 100 & $<100$ \\
\hline $\mathrm{R}-1$ & $<2$ & 0.1 & $<2$ & 130 & $<40$ & $<4$ & $<5$ & 0.05 & 7 & $<1$ & 4 & 10 & $<100$ \\
\hline$R-2$ & $<2$ & $<0.1$ & $<2$ & 130 & $<40$ & $<4$ & $<5$ & 0.11 & 12 & $<1$ & 7 & 11 & $<100$ \\
\hline$R-5$ & 4 & 0.2 & $<2$ & 290 & $<40$ & 9 & $<5$ & 0.19 & 39 & 1 & 12 & 38 & $<100$ \\
\hline$R-6$ & $<2$ & 0.1 & $<2$ & 150 & $<40$ & 6 & $<5$ & 0.07 & 13 & $<1$ & 7 & 35 & $<100$ \\
\hline$R-9$ & $<2$ & 0.1 & $<2$ & 270 & $<40$ & 6 & $<5$ & 0.11 & 18 & $<1$ & 9 & 20 & $<100$ \\
\hline $\mathrm{R}-11$ & 2 & 0.1 & $<2$ & 180 & $<40$ & 5 & $<5$ & 0.12 & 20 & $<1$ & 9 & 35 & $<100$ \\
\hline \multicolumn{14}{|c|}{ Quality assurance/quality control samples } \\
\hline$I-1$ & 4 & 0.4 & $<2$ & 310 & $<40$ & 5 & $<5$ & 0.15 & 28 & 1 & 12 & 43 & $<100$ \\
\hline$I-7$ & 5 & 2.9 & $<2$ & 480 & $<40$ & 7 & $<5$ & 0.23 & 46 & 1 & 13 & 43 & $<100$ \\
\hline
\end{tabular}




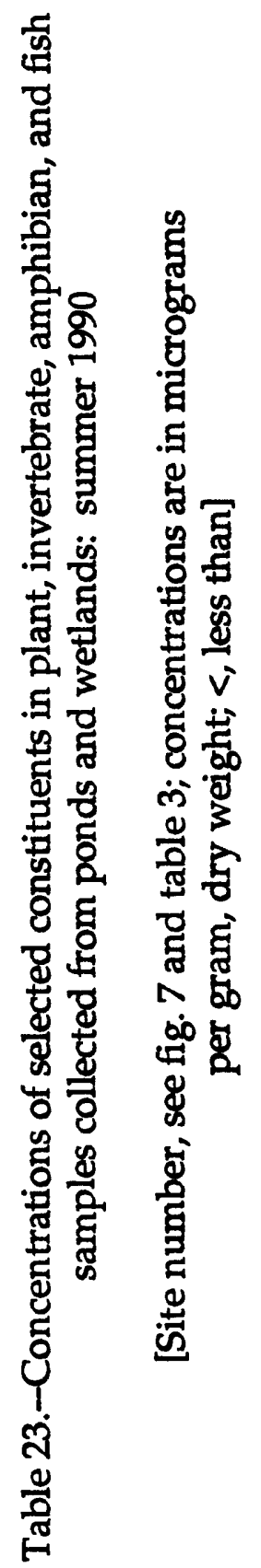

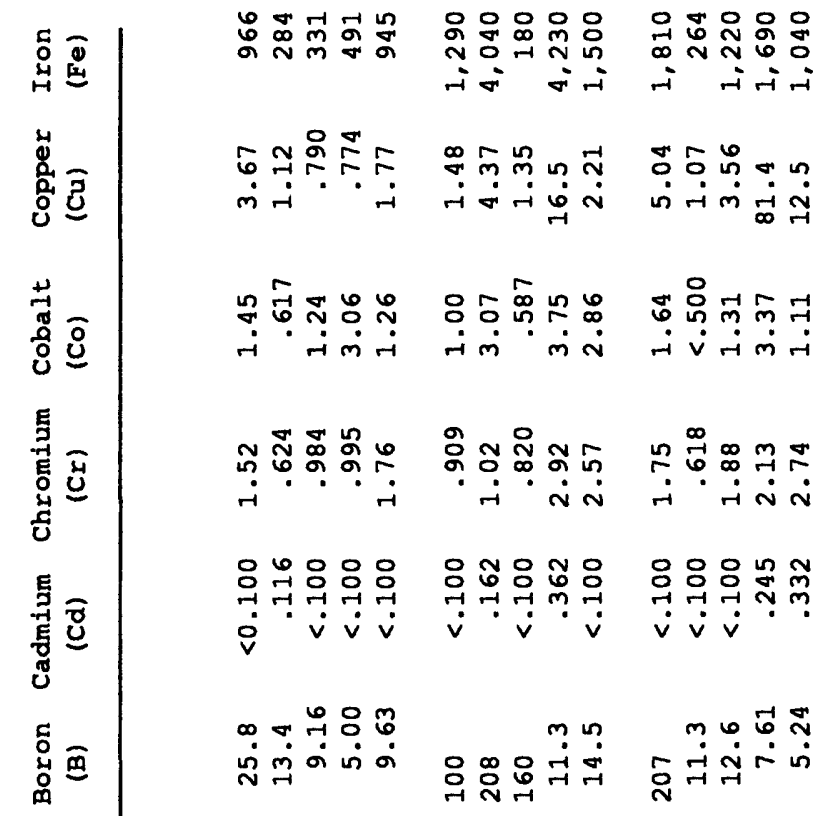

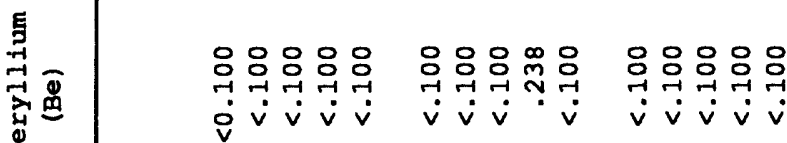
通

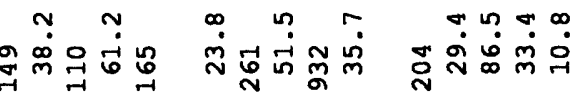

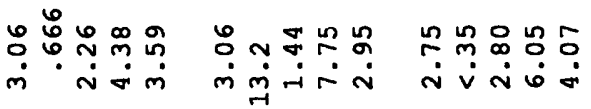

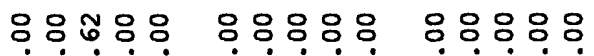

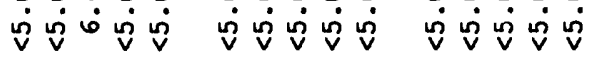
?용

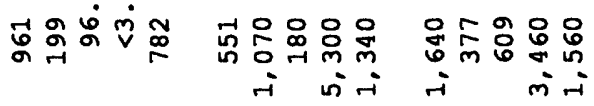

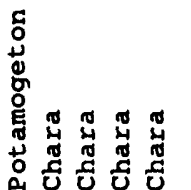

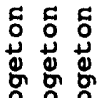

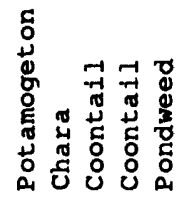

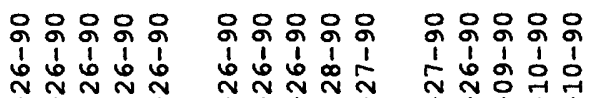

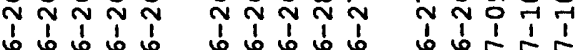

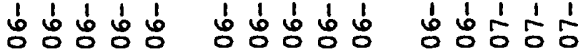

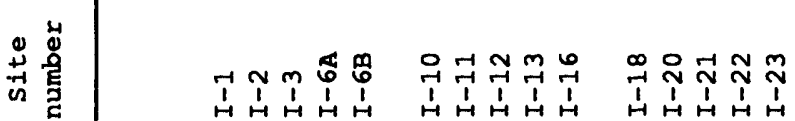




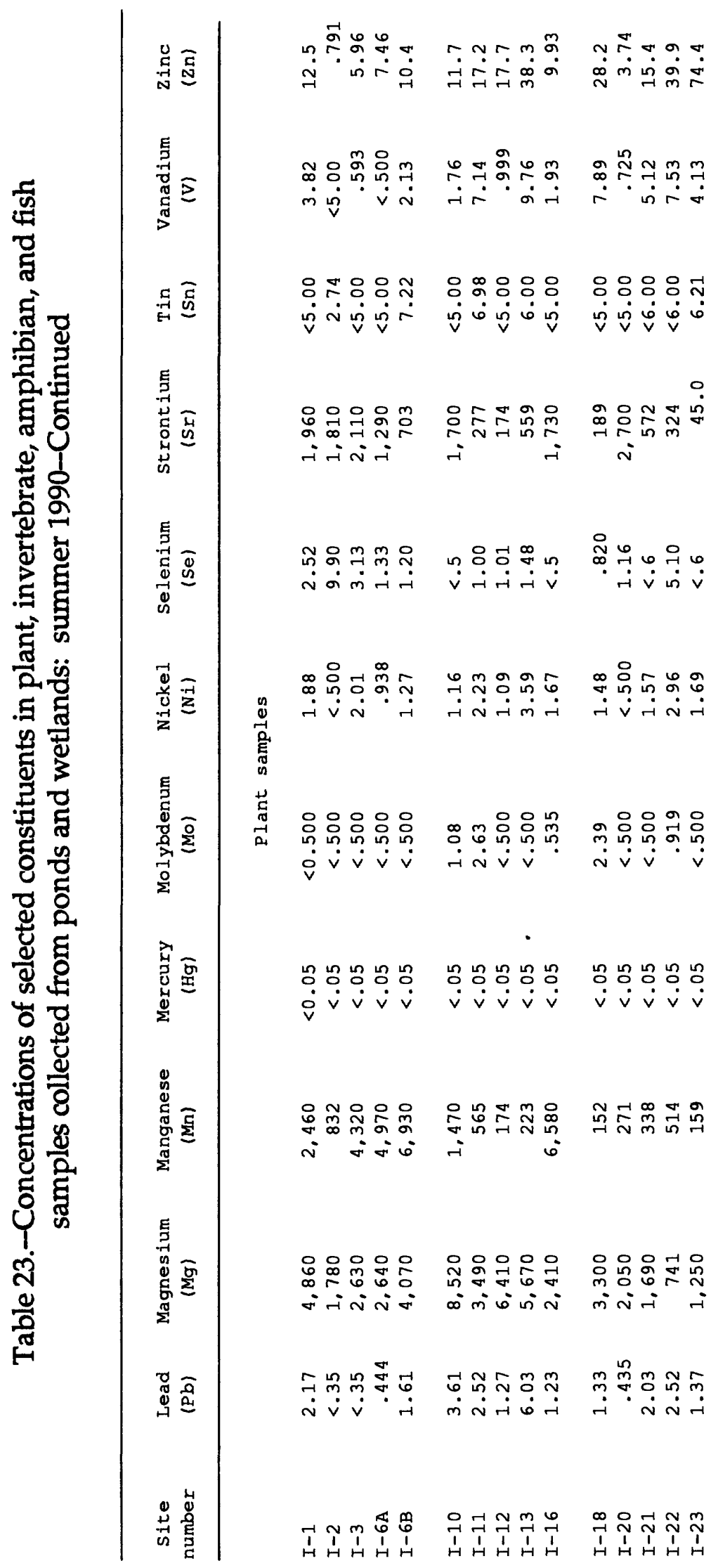




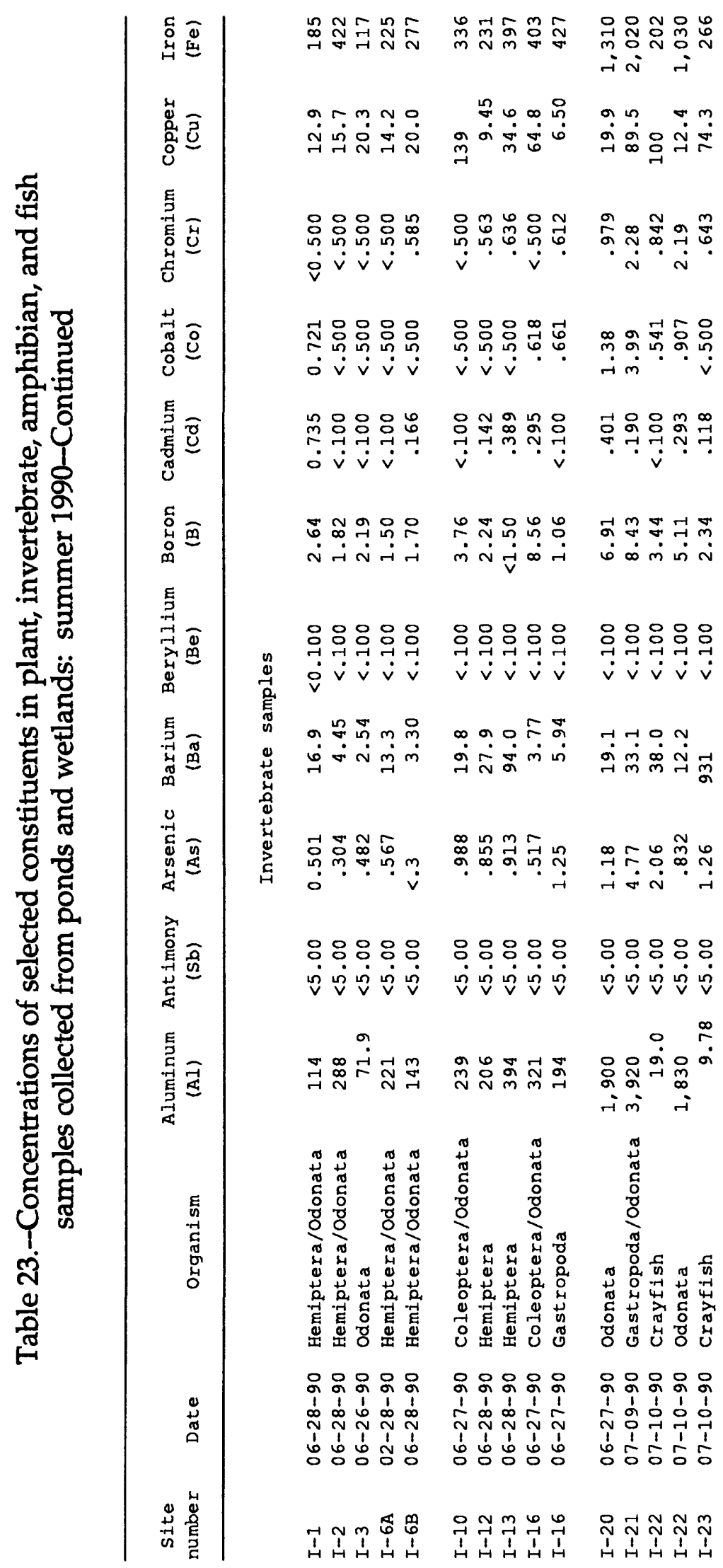




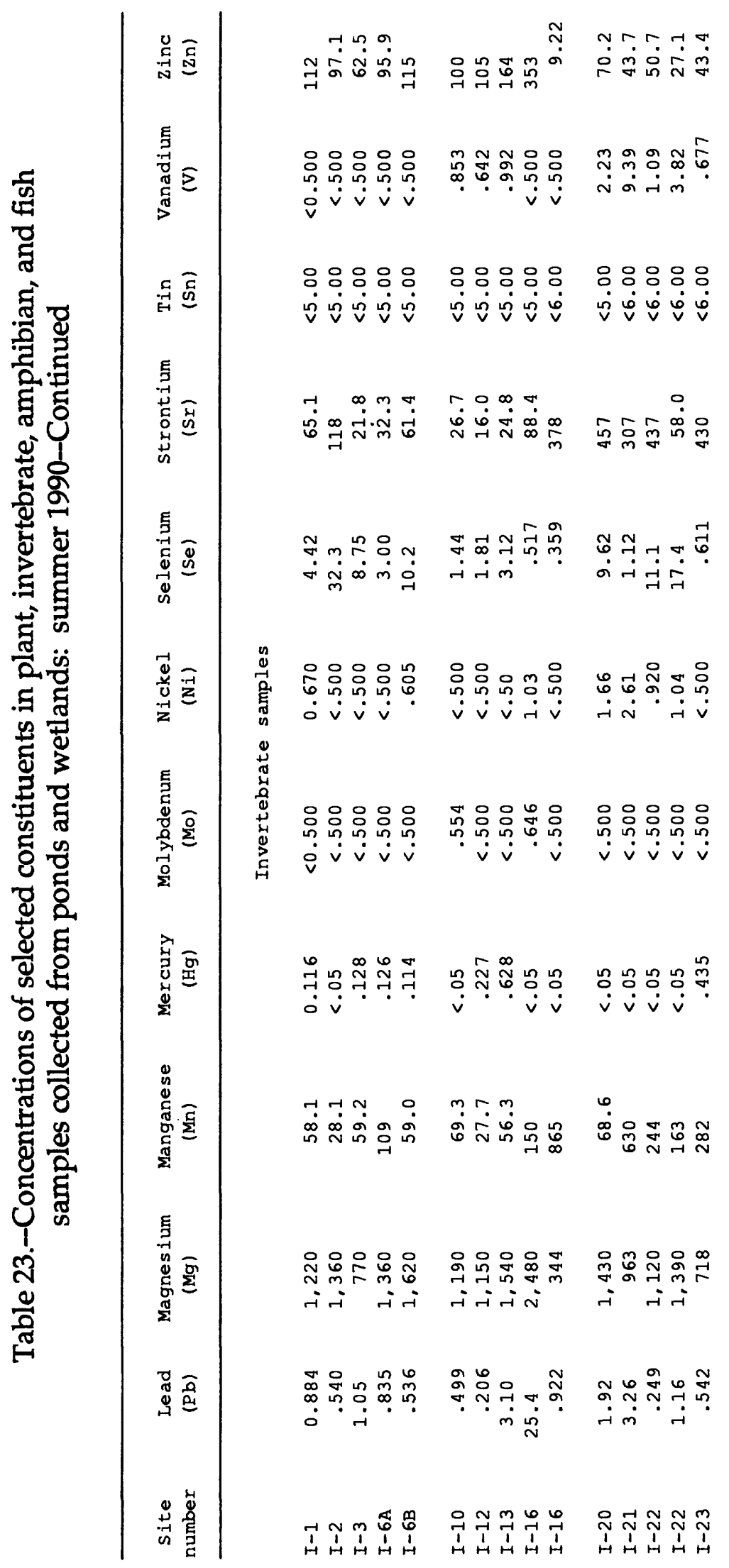




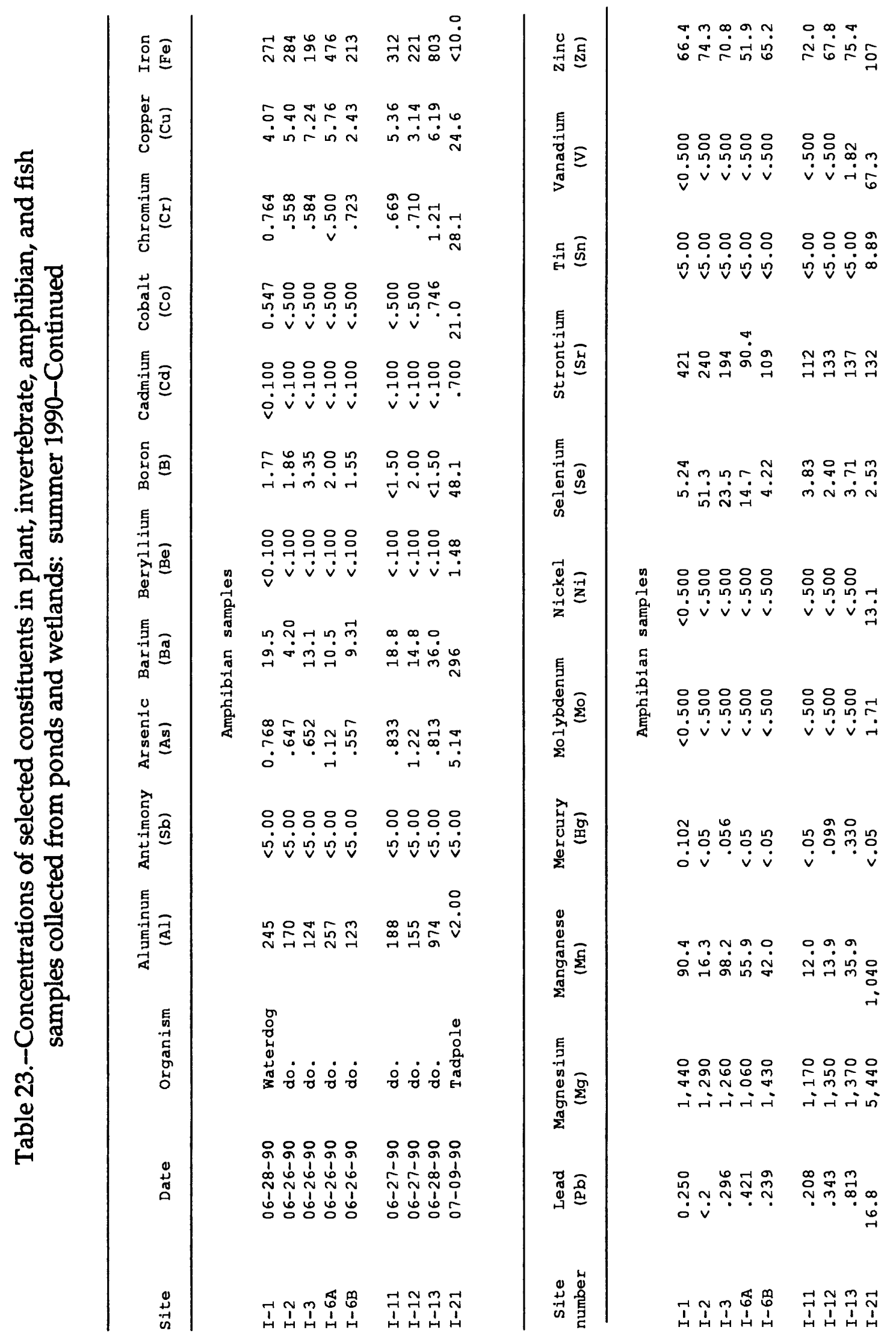




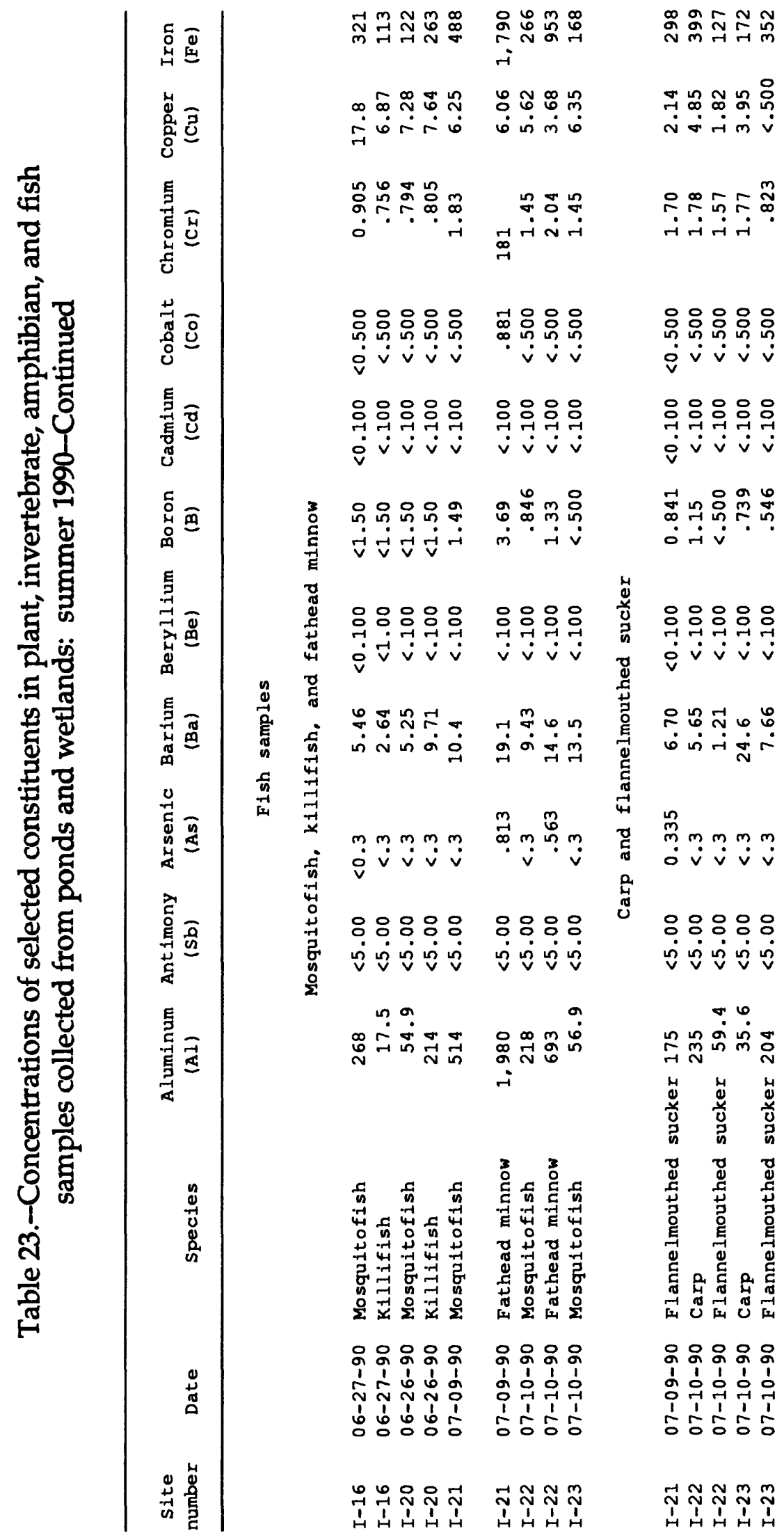




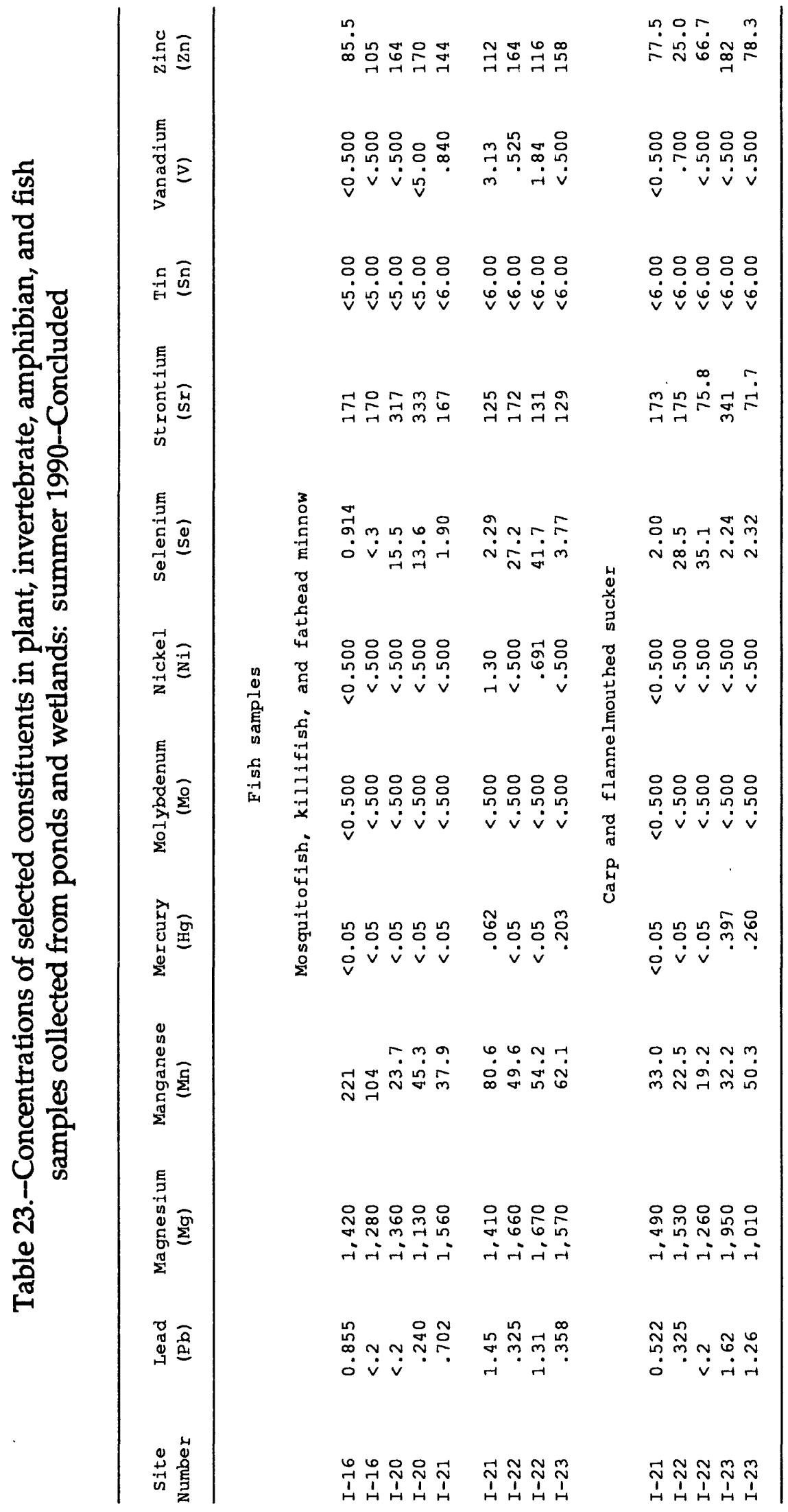




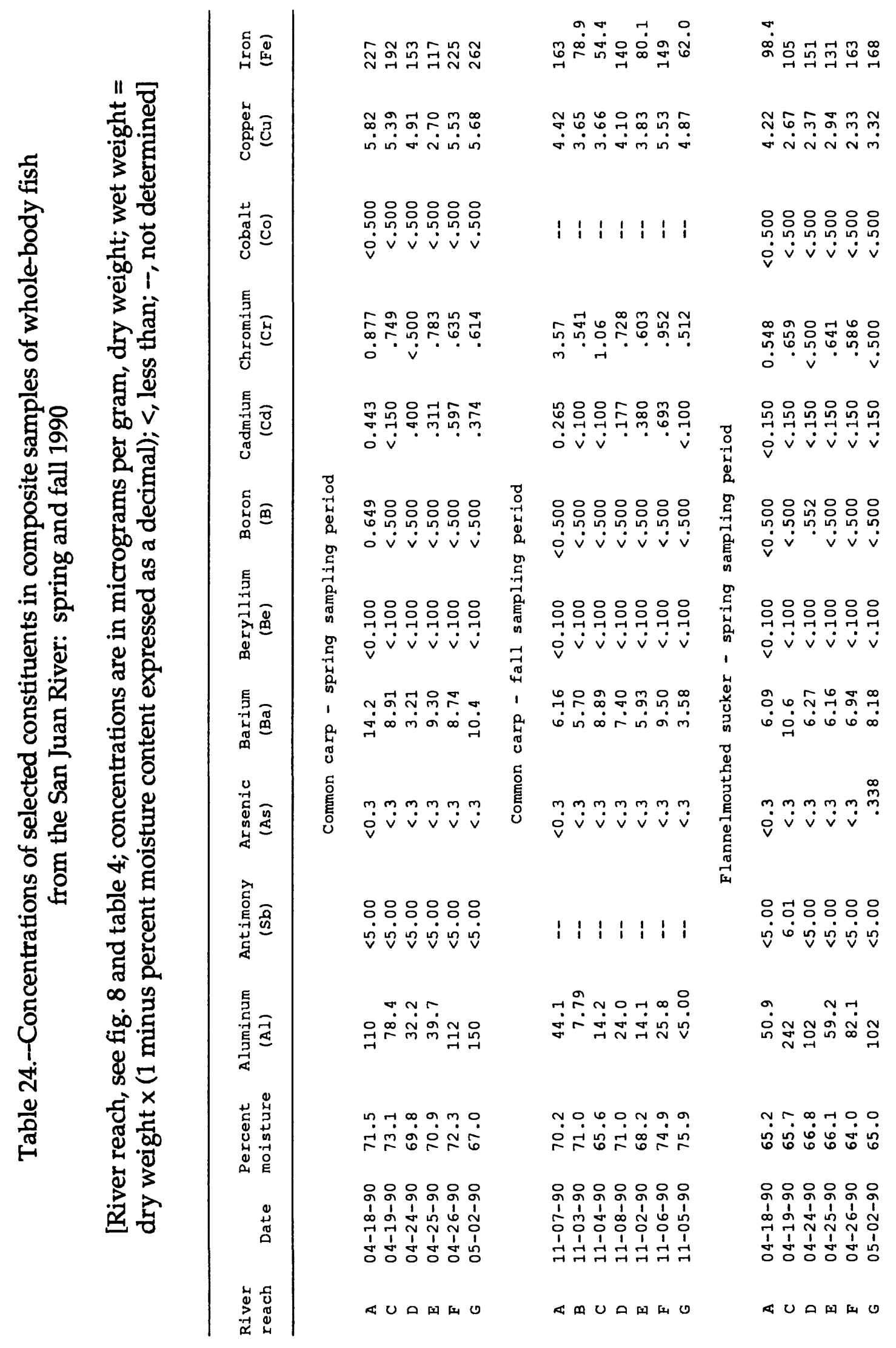




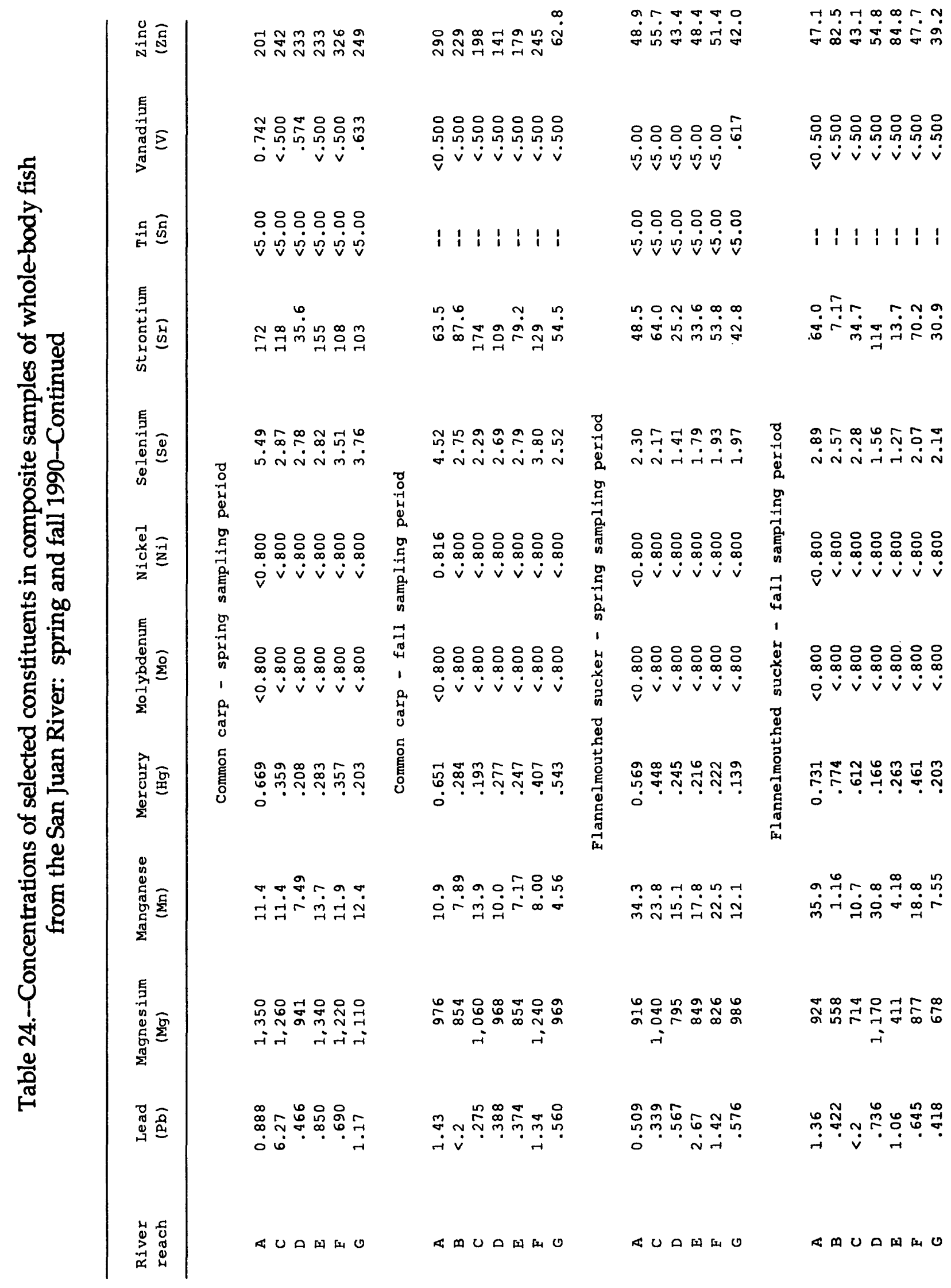




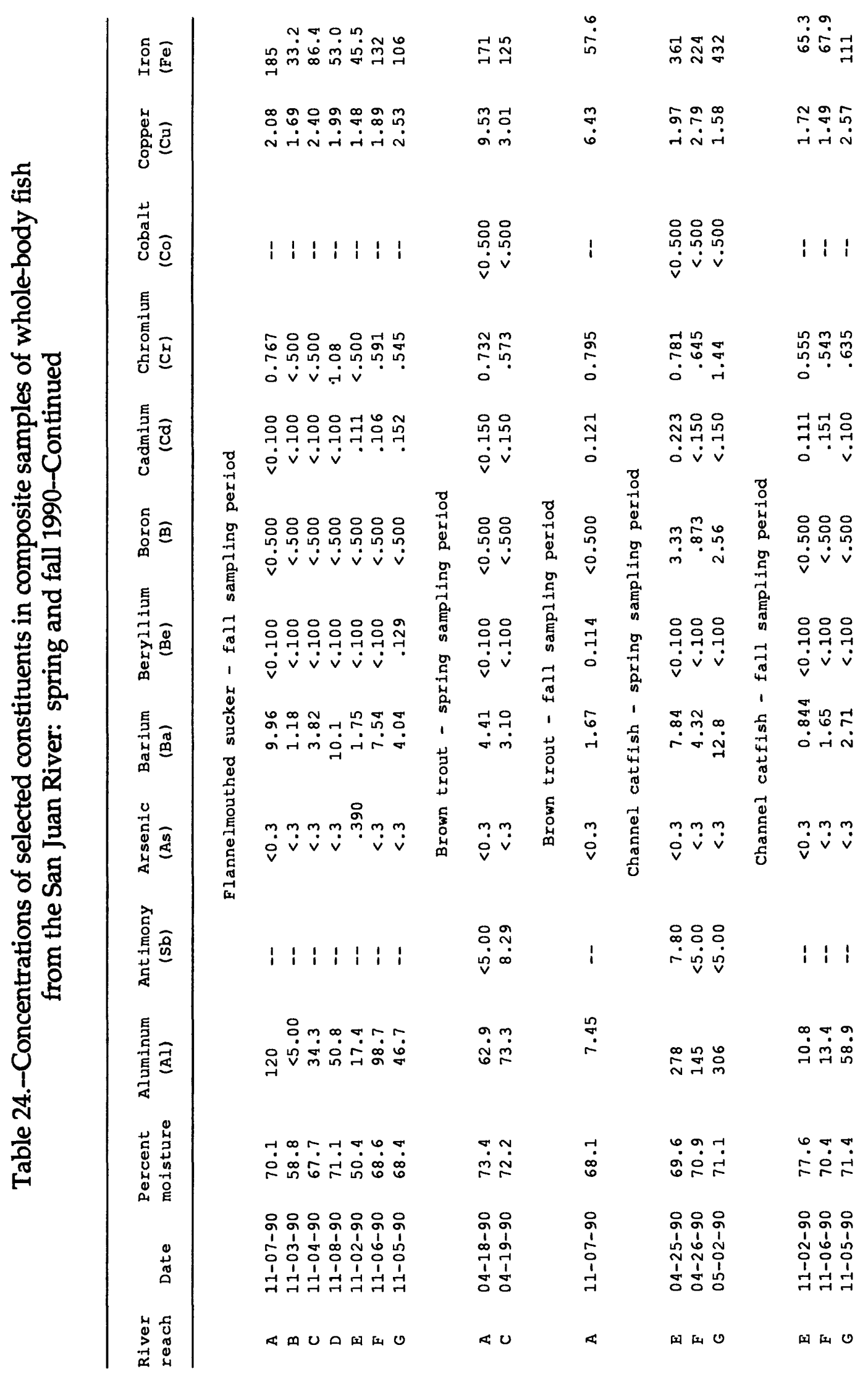




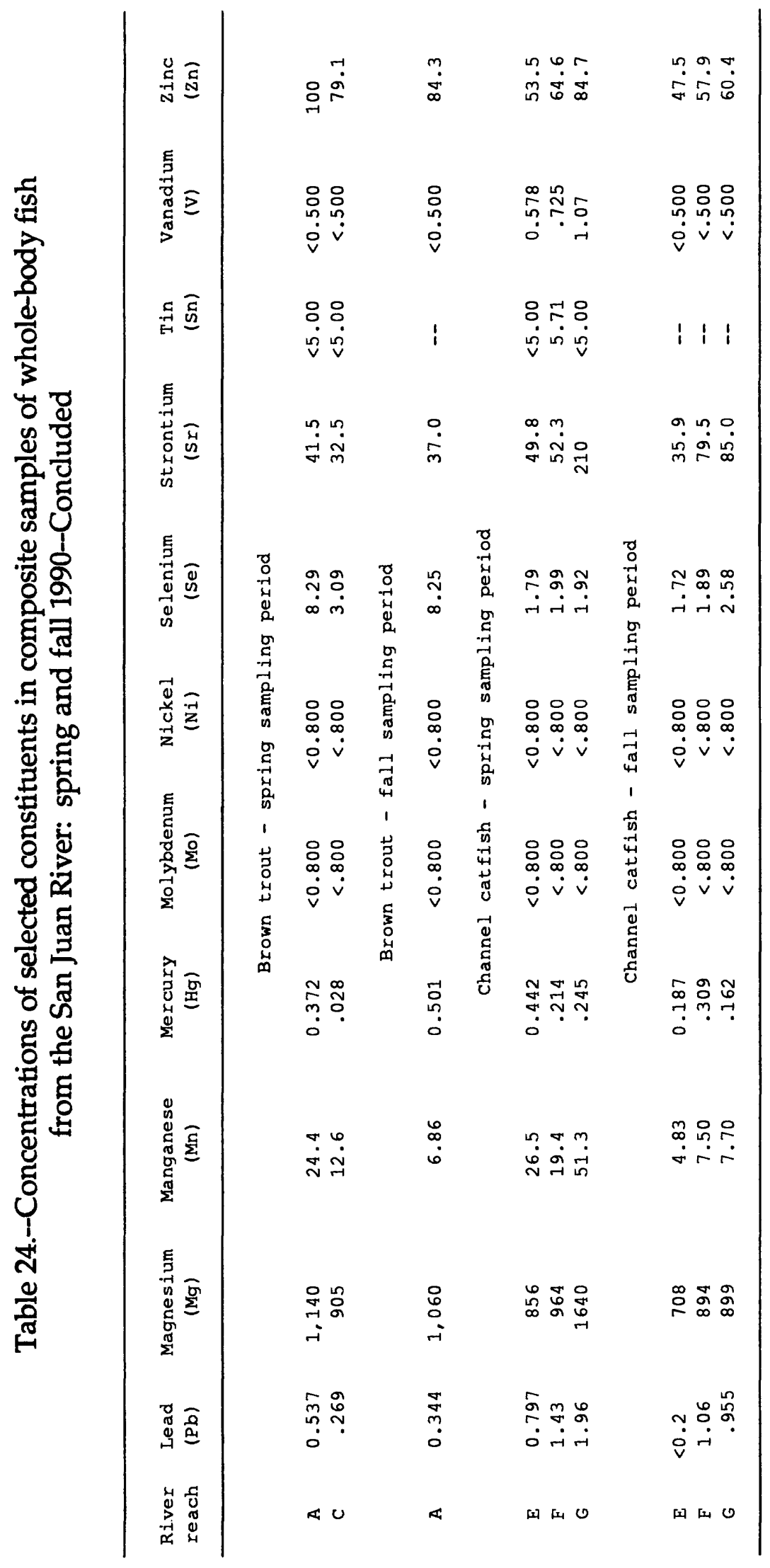


Table 25.-Concentrations of selected constituents in individual edible-portion fish samples from the San Juan River: 1990

[River reach, see fig. 8 and table 4; concentrations are in micrograms per gram, dry weight. Species: Ch. catfish, channel catfish; $\%$, percent; - , not determined; $<$, less than detection level]

\begin{tabular}{|c|c|c|c|c|c|c|c|c|}
\hline $\begin{array}{l}\text { River } \\
\text { reach }\end{array}$ & Species & $\begin{array}{l}\text { Weight } \\
\text { (grams) }\end{array}$ & $\begin{array}{l}\text { Percent } \\
\text { moisture }\end{array}$ & $\begin{array}{l}\text { Alum- } \\
\text { inum }\end{array}$ & Antimony & Arsenic & Barium & $\begin{array}{l}\text { Beryl- } \\
\text { lium }\end{array}$ \\
\hline A & Carp & 304.0 & 65.30 & 6.26 & $<5.00$ & $<0.30$ & 1.03 & $<0.10$ \\
\hline $\mathrm{A}$ & do. & 323.0 & 68.40 & $<5.00$ & $<5.00$ & $<0.30$ & 2.54 & $<0.10$ \\
\hline$A$ & do. & 249.0 & 70.70 & $<5.00$ & $<5.00$ & $<0.30$ & 1.86 & $<0.10$ \\
\hline$A$ & do. & 248.0 & 76.90 & $<5.00$ & $<5.00$ & $<0.30$ & 6.60 & $<0.10$ \\
\hline A & do. & 242.0 & 76.00 & $<5.00$ & $<5.00$ & $<0.30$ & 1.03 & $<0.10$ \\
\hline B & do. & -- & 69.50 & $<3.00$ & $<5.00$ & $<0.30$ & 2.37 & $<0.10$ \\
\hline B & do. & 303.0 & 71.00 & $<2.00$ & $<5.00$ & $<0.30$ & 2.21 & $<0.10$ \\
\hline $\mathrm{B}$ & do. & -- & 75.10 & 15.70 & $<5.00$ & $<0.30$ & 3.15 & $<0.10$ \\
\hline B & do. & -- & 73.80 & 38.40 & $<5.00$ & $<0.30$ & 3.48 & $<0.10$ \\
\hline B & do. & 320.0 & 71.30 & $<2.00$ & $<5.00$ & $<0.30$ & 4.46 & $<0.10$ \\
\hline $\mathrm{D}$ & do. & 454.0 & 76.30 & $<2.00$ & $<5.00$ & $<0.34$ & 3.83 & $<0.10$ \\
\hline$D$ & do. & 468.0 & 72.00 & $<2.00$ & $<5.00$ & $<0.30$ & 9.14 & $<0.10$ \\
\hline$D$ & do. & 673.0 & 71.70 & 9.21 & $<5.00$ & $<0.30$ & 5.18 & $<0.10$ \\
\hline D & do. & 369.0 & 73.80 & 19.70 & $<5.00$ & $<0.32$ & 1.25 & $<0.10$ \\
\hline$D$ & do. & 482.0 & 71.70 & $<2.00$ & $<5.00$ & $<0.30$ & 2.57 & $<0.10$ \\
\hline$E$ & Ch. catfish & 255.0 & 75.80 & 2.23 & $<5.00$ & $<0.30$ & $<0.50$ & $<0.10$ \\
\hline$E$ & Ch. catfish & 142.0 & 72.60 & $<2.00$ & $<5.00$ & $<0.30$ & $<0.50$ & $<0.10$ \\
\hline$E$ & Ch. catfish & 170.0 & 72.30 & $<2.00$ & $<5.00$ & $<0.30$ & $<0.50$ & $<0.10$ \\
\hline $\mathrm{E}$ & Carp & 198.0 & 76.40 & $<5.00$ & $<5.00$ & $<0.30$ & 2.15 & $<0.10$ \\
\hline$E$ & ch. catfish & 198.0 & 76.50 & $<2.00$ & $<5.00$ & $<0.30$ & $<0.50$ & $<0.10$ \\
\hline $\mathbf{E}$ & Ch. catfish & 142.0 & 78.70 & $<2.00$ & $<5.00$ & $<0.30$ & $<0.50$ & $<0.10$ \\
\hline $\mathrm{E}$ & Carp & 283.0 & 77.10 & 38.60 & $<5.00$ & $<0.30$ & 3.13 & $<0.10$ \\
\hline $\mathrm{E}$ & do. & 255.0 & 75.70 & $<5.00$ & $<5.00$ & $<0.30$ & 2.43 & $<0.10$ \\
\hline $\mathrm{E}$ & do. & 283.0 & 75.70 & $<5.00$ & $<5.00$ & $<0.30$ & 2.47 & $<0.10$ \\
\hline $\mathrm{E}$ & do. & 224.0 & 76.50 & $<5.00$ & $<5.00$ & $<0.30$ & 3.63 & $<0.10$ \\
\hline G & do. & 170.0 & 73.40 & $<5.00$ & $<5.00$ & $<0.30$ & 2.16 & $<0.10$ \\
\hline G & do. & 255.0 & 75.10 & $<5.00$ & $<5.00$ & $<0.30$ & 7.16 & $<0.10$ \\
\hline G & Ch. catfish & 511.0 & 68.70 & $<2.00$ & $<5.00$ & $<0.30$ & $<0.50$ & $<0.10$ \\
\hline G & Carp & 198.0 & 72.00 & $<5.00$ & $<5.00$ & $<0.30$ & 3.91 & $<0.10$ \\
\hline G & Ch. catfish & 709.0 & 72.30 & $<2.00$ & $<5.00$ & $<0.30$ & $<0.50$ & $<0.10$ \\
\hline G & Carp & 156.0 & 74.60 & 46.00 & $<5.00$ & $<0.30$ & 4.54 & $<0.10$ \\
\hline G & Carp & 198.0 & 72.50 & $<5.00$ & $<5.00$ & $<0.30$ & 2.30 & $<0.10$ \\
\hline$I$ & Ch. catfish & 198.0 & 71.00 & $<2.00$ & $<5.00$ & $<0.30$ & $<0.50$ & $<0.10$ \\
\hline$I$ & ch. catfish & 142.0 & 71.00 & 13.30 & $<5.00$ & $<0.30$ & $<0.50$ & $<0.10$ \\
\hline$I$ & Ch. catfish & 198.0 & 73.50 & $<2.00$ & $<5.00$ & $<0.30$ & $<0.50$ & $<0.10$ \\
\hline$I$ & Ch. catfish & 170.0 & 71.30 & $<2.00$ & $<5.00$ & $<0.30$ & $<0.50$ & $<0.10$ \\
\hline$I$ & Ch. catfish & 170.0 & 73.10 & 41.00 & $<5.00$ & $<0.30$ & 1.29 & $<0.10$ \\
\hline
\end{tabular}


Table 25.--Concentration of selected constituents in individual edible-portion fish samples from the San Juan River: 1990-Continued

\begin{tabular}{|c|c|c|c|c|c|c|c|c|}
\hline $\begin{array}{l}\text { Rives } \\
\text { reach }\end{array}$ & Species & Boron & Cadmium & Chromium & Cobalt & Copper & Iron & Lead \\
\hline A & Carp & $<0.50$ & $<0.150$ & 0.755 & $<0.500$ & 2.410 & 55.0 & $<0.200$ \\
\hline A & do. & $<0.50$ & $<0.150$ & 0.776 & $<0.500$ & 2.370 & 55.1 & 0.346 \\
\hline A & do. & $<0.50$ & $<0.150$ & 0.915 & $<0.500$ & 2.020 & 60.5 & $<0.200$ \\
\hline $\mathrm{A}$ & do. & 0.61 & $<0.150$ & 0.674 & $<0.500$ & 3.030 & 51.0 & 0.621 \\
\hline $\mathrm{A}$ & do. & $<0.50$ & $<0.150$ & 0.736 & $<0.500$ & 3.370 & 61.0 & $<0.200$ \\
\hline B & do. & $<1.50$ & $<0.100$ & 0.515 & $<0.500$ & 2.240 & 34.1 & $<0.200$ \\
\hline B & do. & $<0.50$ & $<0.100$ & 1.590 & $<0.500$ & 2.250 & 46.8 & 0.255 \\
\hline B & do. & $<1.50$ & $<0.100$ & 0.554 & $<0.500$ & 2.940 & 54.6 & 0.598 \\
\hline $\mathrm{B}$ & do. & $<1.50$ & $<0.100$ & $<0.500$ & $<0.500$ & 2.590 & 81.3 & $<0.200$ \\
\hline B & do. & 0.52 & $<0.100$ & 1.700 & $<0.500$ & 3.660 & 55.0 & 0.345 \\
\hline D & do. & $<0.50$ & $<0.100$ & 0.650 & $<0.500$ & 3.190 & 58.8 & 0.620 \\
\hline D & do. & $<0.50$ & $<0.100$ & 1.370 & $<0.500$ & 2.590 & 57.5 & 0.912 \\
\hline$D$ & do. & $<0.50$ & $<0.100$ & 1.120 & $<0.500$ & 2.540 & 63.7 & 0.355 \\
\hline D & do. & $<0.50$ & $<0.100$ & 0.923 & $<0.500$ & 3.450 & 86.0 & 0.565 \\
\hline D & do. & $<0.50$ & $<0.100$ & 1.120 & $<0.500$ & 2.180 & 42.7 & 0.250 \\
\hline$E$ & Ch. catfish & $<0.50$ & $<0.100$ & 1.080 & $<0.500$ & 2.270 & 19.3 & $<0.200$ \\
\hline $\mathrm{E}$ & Ch. catfish & $<0.50$ & $<0.100$ & 1.250 & $<0.500$ & 2.080 & 19.8 & 1.110 \\
\hline$E$ & Ch. catfish & $<0.50$ & $<0.100$ & $<0.500$ & 1.010 & 2.110 & 17.5 & 0.469 \\
\hline$E$ & Carp & 0.70 & $<0.150$ & $<0.500$ & 0.654 & 3.230 & 67.6 & 0.377 \\
\hline $\mathrm{E}$ & Ch. catfish & $<0.50$ & $<0.100$ & $<0.500$ & 0.989 & 5.000 & 24.0 & 0.240 \\
\hline$E$ & Ch. catfish & $<0.50$ & $<0.100$ & $<0.500$ & 1.550 & 1.220 & 22.7 & $<0.200$ \\
\hline$E$ & Carp & 5.50 & $<0.150$ & 0.612 & 1.040 & 3.540 & 139.0 & 0.239 \\
\hline$E$ & do. & $<0.50$ & 0.170 & $<0.500$ & 0.822 & 3.170 & 63.8 & $<0.200$ \\
\hline $\mathrm{E}$ & do. & $<0.50$ & $<0.150$ & $<0.500$ & 0.874 & 3.070 & 89.9 & 0.525 \\
\hline $\mathrm{E}$ & do. & $<0.50$ & 0.168 & $<0.500$ & 0.792 & 2.770 & 70.7 & 0.387 \\
\hline G & do. & $<0.50$ & $<0.150$ & $<0.500$ & 0.765 & 3.680 & 70.6 & 0.248 \\
\hline G & do. & 0.55 & $<0.150$ & $<0.500$ & 0.931 & 1.650 & 62.3 & 0.868 \\
\hline G & Ch. catfish & $<0.50$ & $<0.100$ & $<0.500$ & 0.833 & 1.660 & 18.9 & $<0.200$ \\
\hline G & Carp & $<0.50$ & $<0.150$ & $<0.500$ & 0.881 & 2.630 & 65.3 & $<0.200$ \\
\hline G & Ch. catfish & $<0.50$ & $<0.100$ & $<0.500$ & 0.913 & 1.680 & 26.6 & 0.375 \\
\hline G & Carp & 2.56 & $<0.150$ & $<0.500$ & 0.848 & 2.960 & 140.0 & 0.559 \\
\hline G & Carp & $<0.50$ & $<0.150$ & $<0.500$ & 0.549 & 4.150 & 77.5 & 0.268 \\
\hline$I$ & Ch. catfish & 0.68 & $<0.100$ & $<0.500$ & 1.210 & 1.830 & 22.0 & $<0.200$ \\
\hline$I$ & Ch. catfish & $<0.50$ & $<0.100$ & $<0.500$ & 1.340 & 0.846 & 56.4 & 0.327 \\
\hline I & Ch. catfish & $<0.50$ & $<0.100$ & $<0.500$ & 1.170 & 1.370 & 21.8 & 0.404 \\
\hline$I$ & Ch. catfish & $<0.50$ & $<0.100$ & $<0.500$ & 0.916 & 1.590 & 19.6 & 0.472 \\
\hline I & Ch. catfish & $<0.50$ & $<0.100$ & $<0.500$ & 1.650 & 2.520 & 65.1 & 0.329 \\
\hline
\end{tabular}


Table 25.--Concentration of selected constituents in individual edible-portion fish samples from the San Juan River: 1990-Continued

\begin{tabular}{|c|c|c|c|c|c|c|c|c|}
\hline $\begin{array}{l}\text { River } \\
\text { reach }\end{array}$ & Species & Ianganese & Mercury & $\begin{array}{l}\text { Molyb- } \\
\text { denum }\end{array}$ & Nickel & Selenium & Silver & Strontium \\
\hline $\mathbf{A}$ & Carp & 0.977 & 0.814 & $<0.80$ & $<0.80$ & 3.05 & $<1.50$ & 8.82 \\
\hline A & do. & 1.870 & 0.890 & $<0.80$ & $<0.80$ & 4.18 & $<1.50$ & 29.30 \\
\hline A & do. & 1.750 & 1.290 & $<0.80$ & $<0.80$ & 2.55 & $<1.50$ & 12.70 \\
\hline A & do. & 3.980 & 0.924 & $<0.80$ & $<0.80$ & 3.25 & $<1.50$ & 73.70 \\
\hline A & do. & 1.200 & 1.040 & $<0.80$ & $<0.80$ & 3.25 & $<1.50$ & 9.85 \\
\hline B & do. & 3.080 & 0.527 & $<0.50$ & $<0.50$ & 3.49 & $<1.50$ & 45.00 \\
\hline B & do. & 3.490 & 0.381 & $<0.50$ & $<0.50$ & 2.19 & $<1.50$ & 76.30 \\
\hline B & do. & 3.340 & 1.050 & $<0.50$ & $<0.50$ & 3.86 & $<1.50$ & 50.20 \\
\hline B & do. & 2.960 & 1.170 & $<0.50$ & $<0.50$ & 4.39 & $<1.50$ & 21.40 \\
\hline B & do. & 5.450 & 0.656 & 0.58 & $<0.50$ & 3.28 & $<1.50$ & 82.50 \\
\hline$D$ & do. & 3.790 & 0.324 & $<0.50$ & $<0.50$ & 2.02 & $<1.50$ & 51.40 \\
\hline $\mathrm{D}$ & do. & 7.960 & 0.308 & $<0.50$ & $<0.50$ & 2.03 & $<1.50$ & 95.10 \\
\hline$D$ & do. & 8.720 & 0.635 & $<0.50$ & $<0.50$ & 1.99 & $<1.50$ & 93.40 \\
\hline$D$ & do. & 1.610 & 0.835 & $<0.50$ & $<0.50$ & 3.77 & $<1.50$ & 14.50 \\
\hline D & do. & 2.660 & 0.408 & $<0.50$ & $<0.50$ & 3.16 & $<1.50$ & 42.80 \\
\hline $\mathrm{E}$ & Ch. catfish & h 1.260 & 0.702 & $<0.50$ & $<0.50$ & 1.03 & $<1.50$ & 2.04 \\
\hline$E$ & Ch. catfish & h 2.420 & 0.359 & $<0.50$ & $<0.50$ & 1.20 & $<1.50$ & 5.55 \\
\hline $\mathbf{E}$ & Ch. catfish & h 1.470 & 0.387 & $<0.50$ & $<0.50$ & 0.91 & $<1.50$ & 4.38 \\
\hline $\mathbf{E}$ & Carp & 2.510 & 0.980 & $<0.80$ & $<0.80$ & 3.18 & $<1.50$ & 26.50 \\
\hline $\mathbf{E}$ & Ch. catfish & h 2.920 & 0.720 & $<0.50$ & $<0.50$ & 1.15 & $<1.50$ & 12.60 \\
\hline $\mathbf{E}$ & Ch. catfish & h 1.180 & 0.386 & $<0.50$ & $<0.50$ & 1.38 & $<1.50$ & 6.40 \\
\hline $\mathbf{E}$ & Carp & 3.590 & 0.533 & $<0.80$ & $<0.80$ & 4.06 & $<1.50$ & 39.50 \\
\hline $\mathbf{E}$ & do. & 2.410 & 0.906 & $<0.80$ & $<0.80$ & 2.68 & $<1.50$ & 37.10 \\
\hline $\mathbf{E}$ & do. & 2.940 & 0.518 & $<0.80$ & $<0.80$ & 2.45 & $<1.50$ & 18.20 \\
\hline $\mathbf{E}$ & do. & 4.370 & 1.090 & $<0.80$ & $<0.80$ & 4.06 & $<1.50$ & 44.30 \\
\hline G & do. & 2.100 & 0.444 & $<0.80$ & $<0.80$ & 3.52 & $<1.50$ & 18.70 \\
\hline G & do. & 6.280 & 0.317 & $<0.80$ & $<0.80$ & 4.93 & $<1.50$ & 83.60 \\
\hline $\mathbf{G}$ & Ch. catfish & h 0.659 & 0.516 & $<0.50$ & $<0.50$ & 0.54 & $<1.50$ & 0.78 \\
\hline G & Carp & 3.460 & 0.885 & $<0.80$ & $<0.80$ & 3.89 & $<1.50$ & 57.40 \\
\hline $\mathbf{G}$ & Ch. catfish & h 1.450 & 1.350 & $<0.50$ & $<0.50$ & 1.41 & $<1.50$ & 11.90 \\
\hline G & Carp & 4.570 & 0.580 & $<0.80$ & $<0.80$ & 5.71 & $<1.50$ & 53.40 \\
\hline $\mathbf{G}$ & Carp & 2.470 & 0.372 & $<0.80$ & $<0.80$ & 3.28 & $<1.50$ & 25.30 \\
\hline$I$ & Ch. catfish & h 1.350 & 0.945 & $<0.50$ & 0.68 & 1.05 & $<1.50$ & 4.21 \\
\hline$I$ & Ch. catfish & h 3.420 & 0.369 & $<0.50$ & $<0.50$ & 1.24 & $<1.50$ & 8.03 \\
\hline$I$ & Ch. catfish & h 2.670 & 0.727 & $<0.50$ & $<0.50$ & 1.12 & $<1.50$ & 11.70 \\
\hline$I$ & Ch. catfish & h 1.850 & 0.328 & $<0.50$ & $<0.50$ & 1.28 & $<1.50$ & 14.80 \\
\hline$I$ & Ch. catfish & h 6.370 & 0.563 & $<0.50$ & $<0.50$ & 1.60 & $<1.50$ & 29.80 \\
\hline
\end{tabular}


Table 25.--Concentration of selected constituents in individual edible-portion fish samples from the San Juan River: 1990--Concluded

\begin{tabular}{|c|c|c|c|c|}
\hline $\begin{array}{l}\text { River } \\
\text { reach }\end{array}$ & species & Tin & Vanadium & Zinc \\
\hline A & Carp & $<5.00$ & $<0.50$ & 89.00 \\
\hline A & do. & $<5.00$ & $<0.50$ & 70.60 \\
\hline A & do. & $<5.00$ & $<0.50$ & 94.30 \\
\hline A & do. & $<5.00$ & $<0.50$ & 117.00 \\
\hline A & do. & $<5.00$ & $<0.50$ & 102.00 \\
\hline B & do. & $<5.00$ & $<0.50$ & 50.30 \\
\hline B & do. & $<6.00$ & $<0.50$ & 93.60 \\
\hline B & do. & $<5.00$ & $<0.50$ & 83.20 \\
\hline B & do. & $<5.00$ & $<0.50$ & 60.90 \\
\hline B & do. & $<6.00$ & $<0.50$ & 87.90 \\
\hline D & do. & $<6.00$ & $<0.50$ & 66.90 \\
\hline D & do. & $<6.00$ & $<0.50$ & 105.00 \\
\hline D & do. & $<6.00$ & $<0.50$ & 63.00 \\
\hline D & do. & $<6.00$ & $<0.50$ & 69.40 \\
\hline D & do. & $<6.00$ & $<0.50$ & 71.60 \\
\hline $\mathrm{E}$ & Ch. catfish & $<6.00$ & $<0.50$ & 49.60 \\
\hline E & Ch. catfish & $<6.00$ & $<0.50$ & 35.60 \\
\hline $\mathrm{E}$ & Ch. catfish & $<6.00$ & $<0.50$ & 37.50 \\
\hline$E$ & Carp & $<5.00$ & 0.59 & 77.90 \\
\hline $\mathrm{E}$ & Ch. catfish & $<6.00$ & $<0.50$ & 62.60 \\
\hline E & Ch. catfish & $<6.00$ & $<0.50$ & 35.70 \\
\hline$E$ & Carp & $<5.00$ & $<0.50$ & 115.00 \\
\hline $\mathrm{E}$ & do. & $<5.00$ & $<0.50$ & 70.10 \\
\hline$E$ & do. & $<5.00$ & $<0.50$ & 56.30 \\
\hline E & do. & $<5.00$ & $<0.50$ & 87.00 \\
\hline G & do. & $<5.00$ & $<0.50$ & 66.90 \\
\hline G & do. & $<5.00$ & 0.51 & 94.50 \\
\hline G & Ch. catfish & $<6.00$ & $<0.50$ & 20.50 \\
\hline G & Carp & $<5.00$ & 0.84 & 100.00 \\
\hline G & Ch. catfish & $<6.00$ & $<0.50$ & 44.40 \\
\hline G & Carp & $<5.00$ & 0.50 & 83.00 \\
\hline G & Carp & 9.39 & $<0.50$ & 91.50 \\
\hline I & Ch. catfish & $<6.00$ & $<0.50$ & 41.30 \\
\hline I & Ch. catfish & $<6.00$ & $<0.50$ & 42.80 \\
\hline$I$ & Ch. catfish & $<6.00$ & $<0.50$ & 30.70 \\
\hline$I$ & Ch. catfish & $<6.00$ & $<0.50$ & 27.30 \\
\hline I & Ch. catfish & $<6.00$ & $<0.50$ & 70.10 \\
\hline
\end{tabular}


Table 26.--Concentrations of selected constituents in livers and kidneys of bird samples: spring 1990

[Site number, see fig. 7 and table 3; concentrations are in micrograms per gram, dry weight; I/C, individual or composite sample-number in parentheses is number in composite sample; species: G.W. teal, green-winged teal; R.W. blackbird, red-winged blackbird;

Y.H. blackbird, yellow-headed blackbird; <, less than]

\begin{tabular}{|c|c|c|c|c|c|c|c|}
\hline $\begin{array}{c}\text { Site } \\
\text { number }\end{array}$ & Date & Species & $I / C$ & $\begin{array}{l}\text { Weight } \\
\text { (grams) }\end{array}$ & $\begin{array}{l}\text { Magnesium } \\
\text { (Mg) }\end{array}$ & $\begin{array}{l}\text { Aluminum } \\
\text { (AI) }\end{array}$ & $\begin{array}{c}\text { Antimons } \\
\text { (sb) }\end{array}$ \\
\hline \multicolumn{8}{|c|}{ Adult birds } \\
\hline$I-1,2,3$ & $05-22-90$ & Mallard & $I$ & 38.5 & 580 & $<2.00$ & $<5.00$ \\
\hline$I-1,2,3$ & $05-22-90$ & Mallard & $I$ & 29.5 & 675 & $<2.00$ & $<5.00$ \\
\hline$I-1,2,3$ & $06-07-90$ & G.W. teal & $I$ & 16.0 & 764 & $<2.00$ & $<5.00$ \\
\hline$I-1,2,3$ & $06-12-90$ & Coot & $I$ & 15.0 & 770 & $<2.00$ & $<5.00$ \\
\hline$I-1,2,3$ & $06-07-90$ & Killdeer & $C(3)$ & 10.7 & 893 & $<2.00$ & $<5.00$ \\
\hline$I-1,2,3$ & $06-07-90$ & R.W. blackbird & $C(6)$ & 14.0 & 822 & 9.71 & $<5.00$ \\
\hline$I-6$ & $05-21-90$ & Mallard & $I$ & 29.0 & 767 & $<2.00$ & $<5.00$ \\
\hline$I-6$ & $05-21-90$ & Mallard & I & 29.0 & 916 & $<2.00$ & $<5.00$ \\
\hline$I-6$ & $06-05-90$ & Killdeer & $c(3)$ & 12.0 & 777 & $<2.00$ & $<5.00$ \\
\hline$I-6$ & $06-05-90$ & Y.H. blackbird & $C(3)$ & 12.0 & 853 & 2.45 & $<5.00$ \\
\hline$I-9$ & $05-23-90$ & Mallard & I & 33.0 & 801 & 3.02 & $<5.00$ \\
\hline$I-9$ & $06-05-90$ & Avocet & I & 10.0 & 946 & 13.9 & $<5.00$ \\
\hline$I-9$ & $06-05-90$ & Avocet & I & 11.0 & 841 & 22.0 & $<5.00$ \\
\hline$I-10$ & $05-23-90$ & Mallard & I & 33.0 & 612 & $<2.00$ & $<5.00$ \\
\hline$I-10$ & $05-24-90$ & Mallard & I & 27.0 & 899 & 3.61 & $<5.00$ \\
\hline$I-10$ & $06-12-90$ & Coot & $I$ & 30.0 & 648 & $<2.00$ & $<5.00$ \\
\hline$I-10$ & $06-12-90$ & Coot & I & 16.0 & 749 & $<2.00$ & $<5.00$ \\
\hline$I-10$ & $06-05-90$ & Avocet & I & 11.0 & 973 & 26.3 & $<5.00$ \\
\hline$I-10$ & $06-05-90$ & Avocet & I & 12.0 & 816 & 6.11 & $<5.00$ \\
\hline$I-10$ & $06-05-90$ & Avocet & I & 13.0 & 775 & $<2.00$ & $<5.00$ \\
\hline$I-10$ & $06-05-90$ & Killdeer & $C(2)$ & 9.0 & 844 & 5.25 & $<5.00$ \\
\hline$I-10$ & $06-05-90$ & Killdeer & $C(2)$ & 9.0 & 940 & $<2.00$ & $<5.00$ \\
\hline
\end{tabular}


Table 26.--Concentrations of selected constituents in livers and kidneys of bird samples: spring 1990-Continued

\begin{tabular}{|c|c|c|c|c|c|c|c|c|}
\hline $\begin{array}{c}\text { Site } \\
\text { number }\end{array}$ & $\begin{array}{c}\text { Arsenic } \\
\text { (As) }\end{array}$ & $\begin{array}{c}\text { Barium } \\
\text { (Ba) }\end{array}$ & $\begin{array}{l}\text { Beryllium } \\
\text { (Be) }\end{array}$ & $\begin{array}{l}\text { Boron } \\
\text { (B) }\end{array}$ & $\begin{array}{l}\text { Cadmium } \\
\text { (Cd) }\end{array}$ & $\begin{array}{l}\text { Chromium } \\
\text { (Cr) }\end{array}$ & $\begin{array}{l}\text { Cobalt } \\
\text { (Co) }\end{array}$ & $\begin{array}{c}\text { Copper } \\
\text { (Cu) }\end{array}$ \\
\hline \multicolumn{9}{|c|}{ Adult birds } \\
\hline$I-1,2,3$ & $<0.3$ & $<5.00$ & $<0.100$ & 4.83 & 1.27 & 0.662 & $<0.500$ & 91.6 \\
\hline$I-1,2,3$ & $<.3$ & $<.500$ & $<.100$ & 3.01 & 3.51 & .511 & $<.500$ & 140 \\
\hline$I-1,2,3$ & $<.3$ & $<.500$ & $<.100$ & .726 & .647 & $<.500$ & $<.500$ & 69.9 \\
\hline$I-1,2,3$ & $<.3$ & $<.500$ & $<.100$ & 5.59 & 1.25 & 1.73 & $<.500$ & 31.8 \\
\hline$I-1,2,3$ & $<.3$ & $<.500$ & $<.100$ & 1.76 & 4.80 & .573 & $<.500$ & 22.8 \\
\hline$I-1,2,3$ & .309 & $<.500$ & $<.100$ & 1.19 & 1.18 & $<.500$ & $<.500$ & 22.7 \\
\hline$I-6$ & $<.3$ & $<.500$ & $<.100$ & 2.63 & 6.00 & .624 & $<.500$ & 70.2 \\
\hline$I-6$ & .329 & .518 & $<.100$ & 3.54 & 1.98 & .726 & $<.500$ & 62.9 \\
\hline$I-6$ & $<.3$ & $<.500$ & $<.100$ & .997 & 2.67 & .931 & $<.500$ & 23.6 \\
\hline$I-6$ & $<.3$ & $<.500$ & .378 & 1.19 & .815 & 1.11 & $<.500$ & 30.0 \\
\hline$I-9$ & $<.3$ & $<.500$ & $<.100$ & 2.51 & 2.60 & .705 & $<.500$ & 66.6 \\
\hline$I-9$ & $<.3$ & 6.31 & .842 & 5.06 & 9.33 & 1.77 & 1.44 & 19.4 \\
\hline$I-9$ & $<.3$ & 4.67 & $<.100$ & 7.33 & 13.6 & .851 & $<.500$ & 17.5 \\
\hline$I-10$ & $<.3$ & .581 & $<.100$ & 2.36 & 2.40 & $<.500$ & $<.500$ & 43.9 \\
\hline$I-10$ & $<.3$ & .797 & $<.100$ & 5.36 & 3.07 & .809 & $<.500$ & 24.6 \\
\hline$I-10$ & .356 & .542 & $<.100$ & 2.37 & 6.80 & .647 & $<.500$ & $11 . .4$ \\
\hline$I-10$ & .329 & 2.84 & $<.100$ & 4.81 & .305 & .582 & $<.500$ & 38.0 \\
\hline$I-10$ & .308 & 1.47 & $<.100$ & 3.65 & 11.7 & 44.6 & $<.500$ & 29.8 \\
\hline$I-10$ & $<.3$ & 3.16 & $<.100$ & 3.42 & 6.86 & 1.94 & $<.500$ & 20.9 \\
\hline$I-10$ & $<.3$ & 11.0 & $<.100$ & 2.52 & 6.38 & .634 & $<.500$ & 20.9 \\
\hline$I-10$ & $<.3$ & 1.02 & $<.100$ & 1.18 & 3.97 & .529 & $<.500$ & 18.2 \\
\hline$I-10$ & $<.3$ & 1.29 & $<.100$ & .914 & 3.55 & .553 & $<.500$ & 21.2 \\
\hline
\end{tabular}


Table 26.--Concentrations of selected constituents in livers and kidneys of bird samples: spring 1990-Continued

\begin{tabular}{|c|c|c|c|c|c|c|}
\hline $\begin{array}{c}\text { Site } \\
\text { number }\end{array}$ & $\begin{array}{l}\text { Iron } \\
(\mathrm{Fe})\end{array}$ & $\begin{array}{l}\text { Lead } \\
(\mathrm{Pb})\end{array}$ & $\begin{array}{l}\text { Manganese } \\
\text { (Mn) }\end{array}$ & $\begin{array}{l}\text { Mercury } \\
(\mathrm{Hg})\end{array}$ & $\begin{array}{l}\text { Molybdenum } \\
\text { (Mo) }\end{array}$ & $\begin{array}{l}\text { Nickel } \\
\text { (Ni) }\end{array}$ \\
\hline \multicolumn{7}{|c|}{ Adult birds } \\
\hline$I-1,2,3$ & 6,220 & 0.265 & 12.8 & 0.409 & 8.60 & $<0.800$ \\
\hline$I-1,2,3$ & 3,470 & .280 & 13.3 & .427 & 3.09 & $<.800$ \\
\hline$I-1,2,3$ & 749 & $<.2$ & 12.6 & .908 & 3.27 & $<.800$ \\
\hline$I-1,2,3$ & 6,530 & .337 & 12.8 & .103 & 10.4 & $<.800$ \\
\hline$I-1,2,3$ & 1,710 & $<.2$ & 19.3 & 1.28 & 4.15 & $<.800$ \\
\hline$I-1,2,3$ & 1,350 & $<.2$ & 7.10 & .185 & 3.32 & $<.800$ \\
\hline$I-6$ & 3,400 & .289 & 14.8 & .881 & 2.36 & $<.800$ \\
\hline$I-6$ & 3,760 & .319 & 34.8 & 1.56 & 3.56 & $<.800$ \\
\hline$I-6$ & 722 & $<.2$ & 16.8 & 1.25 & 3.59 & $<.800$ \\
\hline$I-6$ & 1,430 & $<.2$ & 8.41 & .657 & 3.27 & $<.800$ \\
\hline$I-9$ & 3,170 & .314 & 17.7 & .236 & 3.65 & $<.800$ \\
\hline$I-9$ & 4,920 & $<.2$ & 22.2 & .704 & 4.97 & 4.31 \\
\hline$I-9$ & 3,350 & .428 & 18.9 & 1.33 & 3.01 & $<.800$ \\
\hline$I-10$ & 2,400 & .216 & 11.3 & .151 & 2.27 & $<.800$ \\
\hline$I-10$ & 6,720 & .781 & 17.0 & .379 & 6.29 & $<.800$ \\
\hline$I-10$ & 1,490 & $<.2$ & 7.72 & .363 & 3.77 & $<.800$ \\
\hline$I-10$ & 528 & .240 & 20.3 & .362 & 2.02 & $<.800$ \\
\hline$I-10$ & 4,400 & .992 & 18.7 & 1.18 & 3.94 & $<.800$ \\
\hline$I-10$ & 3,630 & .250 & 19.1 & 1.27 & 5.13 & $<.800$ \\
\hline$I-10$ & 2,760 & .288 & 14.6 & 1.42 & 3.11 & $<.800$ \\
\hline$I-10$ & 960 & $<.2$ & 14.0 & .567 & 2.57 & $<.800$ \\
\hline$I-10$ & 905 & .499 & 15.6 & .738 & 2.82 & $<.800$ \\
\hline
\end{tabular}


Table 26.--Concentrations of selected constituents in livers and kidneys of bird samples: spring 1990-Continued

\begin{tabular}{|c|c|c|c|c|c|}
\hline $\begin{array}{c}\text { Site } \\
\text { number }\end{array}$ & $\begin{array}{l}\text { Selenium } \\
\text { (Se) }\end{array}$ & $\begin{array}{l}\text { Strontium } \\
\text { (Sr) }\end{array}$ & $\begin{array}{l}\text { Tin } \\
(\mathrm{Sn})\end{array}$ & $\begin{array}{l}\text { Vanadium } \\
\text { (V) }\end{array}$ & $\begin{array}{l}\text { Zinc } \\
(Z n)\end{array}$ \\
\hline \multicolumn{6}{|c|}{ Adult birds } \\
\hline$I-1,2,3$ & 23.0 & 0.639 & $<5.00$ & $<0.500$ & 92.9 \\
\hline$I-1,2,3$ & 19.7 & .669 & $<5.00$ & $<.500$ & 96.0 \\
\hline$I-1,2,3$ & 39.3 & $<.500$ & $<5.00$ & $<.500$ & 104 \\
\hline$I-1,2,3$ & 21.6 & 1.28 & $<5.00$ & $<.500$ & 136 \\
\hline$I-1,2,3$ & 103 & .612 & $<5.00$ & $<.500$ & 99.7 \\
\hline$I-1,2,3$ & 42.9 & .635 & $<5.00$ & $<.500$ & 83.4 \\
\hline$I-6$ & 25.0 & .601 & $<5.00$ & $<.500$ & 126 \\
\hline$I-6$ & 16.0 & 4.91 & $<5.00$ & $<.500$ & 189 \\
\hline$I-6$ & 31.2 & $<.500$ & $<5.00$ & $<.500$ & 84.8 \\
\hline$I-6$ & 14.1 & 7.37 & $<5.00$ & $<.500$ & 93.3 \\
\hline$I-9$ & 22.0 & $<.500$ & $<5.00$ & $<.500$ & 118 \\
\hline$I-9$ & 12.5 & 1.51 & $<5.00$ & 1.69 & 133 \\
\hline$I-9$ & 15.3 & 2.28 & $<5.00$ & .985 & 104 \\
\hline$I-10$ & 2.84 & $<.500$ & $<5.00$ & $<.500$ & 96.4 \\
\hline$I-10$ & 12.5 & .879 & $<5.00$ & $<.500$ & 120 \\
\hline$I-10$ & 2.74 & .681 & $<5.00$ & .607 & 88.9 \\
\hline$I-10$ & 5.93 & 16.0 & $<5.00$ & .529 & 114 \\
\hline$I-10$ & 9.34 & 1.63 & $<5.00$ & .544 & 144 \\
\hline$I-10$ & 20.3 & .822 & $<5.00$ & $<.500$ & 119 \\
\hline$I-10$ & 19.5 & 2.34 & $<5.00$ & $<.500$ & 124 \\
\hline$I-10$ & 10.8 & 1.00 & $<5.00$ & $<.500$ & 80.7 \\
\hline$I-10$ & 16.4 & 1.49 & $<5.00$ & $<.500$ & 87.6 \\
\hline
\end{tabular}




\section{Table 26.--Concentrations of selected constituents in livers and kidneys of bird samples: spring 1990-Continued}

\begin{tabular}{|c|c|c|c|c|c|c|c|c|}
\hline $\begin{array}{c}\text { Site } \\
\text { number }\end{array}$ & Date & Species & $I / C$ & $\begin{array}{l}\text { Weight } \\
\text { (grams) }\end{array}$ & $\begin{array}{c}\text { Magnesium } \\
\text { (Mg) }\end{array}$ & $\begin{array}{l}\text { Aluminum } \\
\text { (Al) }\end{array}$ & $\begin{array}{l}\text { Antimony } \\
\text { (Sb) }\end{array}$ & $\begin{array}{c}\text { Arsenic } \\
\text { (As) }\end{array}$ \\
\hline \multicolumn{9}{|c|}{ Adult birds } \\
\hline$I-10$ & $06-12-90$ & Blackbird & $c(7)$ & 9.0 & 856 & $<2.00$ & $<5.00$ & $<0.3$ \\
\hline$I-12$ & $06-05-90$ & Mallard & I & 39.0 & 730 & $<2.00$ & $<5.00$ & $<.3$ \\
\hline$I-16$ & $06-08-90$ & Cinnamon teal & I & 15.0 & 820 & 6.55 & $<5.00$ & $<.3$ \\
\hline$I-16$ & $06-08-90$ & Killdeer & $C(3)$ & 12.0 & 873 & $<2.00$ & $<5.00$ & .667 \\
\hline$I-17$ & $06-08-90$ & Cinnamon teal & I & 19.0 & 808 & $<2.00$ & $<5.00$ & $<.3$ \\
\hline$I-17$ & $06-08-90$ & Cinnamon teal & $I$ & 10.0 & 759 & $<2.00$ & $<5.00$ & $<.3$ \\
\hline$I-17$ & $06-08-90$ & Killdeer & I & 12.0 & 863 & $<2.00$ & $<5.00$ & $<.3$ \\
\hline$I-17$ & $06-08-90$ & Killdeer & $C(2.5)$ & 9.50 & 827 & 4.55 & $<5.00$ & $<.3$ \\
\hline $\mathrm{I}-17$ & $06-08-90$ & R.W. blackbird & $C(4)$ & 8.0 & 880 & $<2.00$ & $<5.00$ & $<.3$ \\
\hline$I-20$ & $06-12-90$ & Mallard & I & 32.0 & 863 & $<2.00$ & $<5.00$ & .483 \\
\hline$I-20$ & $06-12-90$ & Mallard & I & 66.0 & 429 & $<2.00$ & $<5.00$ & $<.3$ \\
\hline$I-20$ & $06-12-90$ & R.W. blackb1rd & $C(6)$ & 12.0 & 786 & $<2.00$ & $<5.00$ & $<.3$ \\
\hline$I-21$ & $06-13-90$ & Mallard & $I$ & 34.0 & 685 & 8.72 & $<5.00$ & $<.3$ \\
\hline$I-21$ & $06-14-90$ & Cinnamon teal & I & 13.5 & 784 & 41.4 & $<5.00$ & $<.3$ \\
\hline$I-21$ & $06-14-90$ & Cinnamon teal & I & 16.0 & 852 & 4.01 & $<5.00$ & $<.3$ \\
\hline$I-21$ & $06-14-90$ & Cinnamon teal & $I$ & 20.0 & 875 & 3.06 & $<5.00$ & $<.3$ \\
\hline$I-21$ & $06-13-90$ & Killdeer & $c(3)$ & 12.0 & 798 & 15.2 & $<5.00$ & $<.3$ \\
\hline$I-21$ & $06-13-90$ & R.W. blackbird & $c(5)$ & 12.0 & 816 & 14.9 & $<5.00$ & $<.3$ \\
\hline$I-23$ & $06-06-90$ & $\operatorname{coot}$ & I & 15.0 & 798 & 21.8 & $<5.00$ & $<.3$ \\
\hline$I-23$ & $06-06-90$ & Coot & I & 17.0 & 663 & 6.69 & $<5.00$ & .586 \\
\hline$I-23$ & $06-06-90$ & Coot & I & 11.0 & 550 & 6.11 & $<5.00$ & $<.3$ \\
\hline$I-23$ & $06-06-90$ & Coot & I & 9.0 & 751 & 7.14 & $<5.00$ & .338 \\
\hline$I-23$ & $06-06-90$ & Coot & $\mathrm{I}$ & 17.0 & 863 & 14.1 & $<5.00$ & .325 \\
\hline$I-23$ & $06-06-90$ & R.W. blackbird & $C(6)$ & 9.0 & 869 & 3.26 & $<5.00$ & $<.3$ \\
\hline
\end{tabular}


Table 26.--Concentrations of selected constituents in livers and kidneys of bird samples: spring 1990-Continued

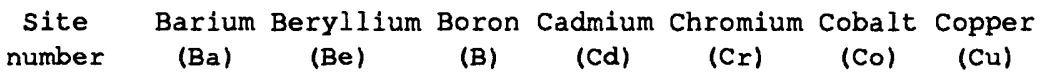

\begin{tabular}{|c|c|c|c|c|c|c|c|}
\hline \multirow[b]{2}{*}{$I-10$} & \multicolumn{5}{|c|}{ Adult birds } & \multirow[b]{2}{*}{$<0.500$} & \multirow[b]{2}{*}{24.5} \\
\hline & $<0.500$ & $<0.100$ & 2.47 & 0.766 & 0.611 & & \\
\hline$I-12$ & $<.500$ & $<.100$ & 2.78 & 3.01 & .810 & $<.500$ & 30.8 \\
\hline$I-16$ & $<.500$ & $<.100$ & 1.50 & 5.45 & $<.500$ & $<.500$ & 59.2 \\
\hline$I-16$ & $<.500$ & $<.100$ & $<.500$ & 5.07 & $<.500$ & $<.500$ & 25.2 \\
\hline$I-17$ & $<.500$ & $<.100$ & $<.500$ & 2.37 & $<.500$ & $<.500$ & 42.1 \\
\hline$I-17$ & $<.500$ & $<.100$ & 2.21 & 9.27 & .733 & $<.500$ & 227 \\
\hline$I-17$ & .504 & $<.100$ & $<.500$ & 1.53 & $<.500$ & $<.500$ & 24.4 \\
\hline$I-17$ & $<.500$ & $<.100$ & $<.500$ & 1.48 & $<.500$ & $<.500$ & 22.6 \\
\hline$I-17$ & $<.500$ & $<.100$ & .779 & .743 & $<.500$ & $<.500$ & 27.8 \\
\hline$I-20$ & .500 & $<.100$ & 2.89 & 3.44 & .586 & $<.500$ & 137 \\
\hline$I-20$ & $<.500$ & $<.100$ & 1.42 & .903 & $<.500$ & $<.500$ & 264 \\
\hline$I-20$ & $<.500$ & $<.100$ & 1.00 & 1.24 & $<.500$ & $<.500$ & 24.8 \\
\hline$I-21$ & .759 & .544 & 2.72 & 6.17 & .985 & .760 & 200 \\
\hline$I-21$ & .666 & $<.100$ & 6.58 & 2.12 & .793 & $<.500$ & 89.8 \\
\hline$I-21$ & $<.500$ & $<.100$ & 5.68 & 2.16 & .650 & $<.500$ & 28.9 \\
\hline$I-21$ & .687 & $<.100$ & 2.34 & 2.02 & .686 & $<.500$ & 17.3 \\
\hline$I-21$ & .858 & $<.100$ & 1.19 & 10.3 & $<.500$ & .629 & 24.0 \\
\hline$I-21$ & $<.500$ & $<.100$ & 1.65 & 1.32 & .536 & $<.500$ & 24.8 \\
\hline$I-23$ & .933 & $<.100$ & 6.47 & .414 & .780 & $<.500$ & 57.8 \\
\hline$I-23$ & $<.500$ & $<.100$ & 3.44 & .619 & .545 & $<.500$ & 34.2 \\
\hline$I-23$ & $<.500$ & $<.100$ & 2.58 & .421 & $<.500$ & $<.500$ & 19.6 \\
\hline$I-23$ & .910 & $<.100$ & 9.72 & .238 & .882 & $<.500$ & 32.7 \\
\hline$I-23$ & 1.43 & $<.100$ & 10.2 & .680 & 1.08 & $<.500$ & 54.0 \\
\hline$I-23$ & $<.500$ & $<.100$ & 1.07 & 1.16 & $<.500$ & .611 & 12.7 \\
\hline
\end{tabular}


Table 26.--Concentrations of selected constituents in livers and kidneys of bird samples: spring 1990-Continued

\begin{tabular}{|c|c|c|c|c|c|}
\hline $\begin{array}{c}\text { site } \\
\text { number }\end{array}$ & $\begin{array}{l}\text { Iron } \\
\text { (Fe) }\end{array}$ & $\begin{array}{l}\text { Lead } \\
(\mathrm{Pb})\end{array}$ & $\begin{array}{c}\text { Manganese } \\
(\mathrm{Mn})\end{array}$ & $\begin{array}{c}\text { Mercury } \\
\text { (Hg) }\end{array}$ & $\begin{array}{r}\text { Molybde } \\
\text { (Mo) }\end{array}$ \\
\hline & & \multicolumn{4}{|c|}{ Adult birds } \\
\hline$I-10$ & 2,690 & 0.229 & 6.18 & 0.524 & 4.02 \\
\hline$I-12$ & 2,620 & .246 & 15.5 & 1.15 & 3.76 \\
\hline$I-16$ & 2,550 & .346 & 32.0 & 1.78 & 3.10 \\
\hline$I-16$ & 904 & $<.5$ & 28.4 & 1.32 & 2.72 \\
\hline$I-17$ & 851 & .336 & 25.9 & 1.13 & 2.36 \\
\hline$I-17$ & 2,750 & .269 & 18.7 & 2.69 & 8.35 \\
\hline$I-17$ & 607 & .329 & 20.6 & 1.05 & 2.20 \\
\hline$I-17$ & 792 & $<.2$ & 18.0 & 1.60 & 2.82 \\
\hline$I-17$ & 977 & $<.2$ & 7.12 & .401 & 3.29 \\
\hline$I-20$ & 1,980 & .385 & 28.9 & 1.66 & 4.37 \\
\hline$I-20$ & 920 & $<.2$ & 10.7 & $<.02$ & 1.87 \\
\hline$I-20$ & 974 & $<.5$ & 5.83 & .144 & 2.60 \\
\hline$I-2 I$ & 2,100 & 1.08 & 13.1 & .930 & 4.40 \\
\hline$I-2 I$ & 8,790 & .966 & 19.7 & 1.78 & 7.05 \\
\hline$I-2 I$ & 4,990 & .615 & 11.0 & .320 & 3.20 \\
\hline$I-2 I$ & 1,110 & .490 & 14.7 & .144 & 2.47 \\
\hline$I-21$ & 771 & 1.11 & 17.6 & .858 & 3.20 \\
\hline$I-21$ & 1,300 & .778 & 7.58 & .224 & 2.95 \\
\hline$I-23$ & 5,900 & .856 & 20.2 & .133 & 2.74 \\
\hline$I-23$ & 3,660 & 1.11 & 16.8 & .233 & 3.35 \\
\hline$I-23$ & 1,240 & .464 & 24.5 & $<.02$ & 1.35 \\
\hline$I-23$ & 10,500 & .606 & 17.7 & .0849 & 6.72 \\
\hline$I-23$ & 13,100 & .947 & 71.3 & .0320 & 7.66 \\
\hline$I-23$ & 800 & & 8.07 & $<.02$ & 3.05 \\
\hline
\end{tabular}


Table 26.--Concentrations of selected constituents in livers and kidneys of bird samples: spring 1990-Continued

\begin{tabular}{|c|c|c|c|c|c|c|}
\hline $\begin{array}{c}\text { Site } \\
\text { number }\end{array}$ & $\begin{array}{l}\text { Nickel } \\
\quad(\mathrm{Ni})\end{array}$ & $\begin{array}{c}\text { Selenium } \\
\text { (Se) }\end{array}$ & $\begin{array}{l}\text { Strontium } \\
\text { (Sr) }\end{array}$ & $\begin{array}{l}\text { Tin } \\
(S n)\end{array}$ & $\begin{array}{l}\text { Vanadium } \\
\text { (V) }\end{array}$ & $\begin{array}{l}Z \text { inc } \\
(\mathrm{Zn})\end{array}$ \\
\hline \multicolumn{7}{|c|}{ Adult birds } \\
\hline$I-10$ & $<0.800$ & 9.54 & 1.70 & $<5.00$ & $<0.500$ & 77.8 \\
\hline$I-12$ & $<.800$ & 17.9 & .611 & $<5.00$ & $<.500$ & 133 \\
\hline$I-16$ & $<.800$ & 8.98 & 1.68 & $<5.00$ & $<.500$ & 113 \\
\hline$I-16$ & $<.800$ & 15.1 & 1.20 & $<5.00$ & $<.500$ & 94.6 \\
\hline$I-17$ & $<.800$ & 7.68 & 2.32 & $<5.00$ & $<.500$ & 85.0 \\
\hline$I-17$ & $<.800$ & 26.4 & .666 & $<5.00$ & $<.500$ & 141 \\
\hline$I-17$ & $<.800$ & 14.4 & 2.14 & $<5.00$ & $<.500$ & 88.5 \\
\hline$I-17$ & $<.800$ & 19.2 & 4.32 & $<5.00$ & $<.500$ & 90.5 \\
\hline$I-17$ & $<.800$ & 11.2 & $<.500$ & $<5.00$ & $<.500$ & 86.5 \\
\hline$I-20$ & $<.800$ & 25.9 & .974 & $<5.00$ & $<.500$ & 124 \\
\hline$I-20$ & $<.800$ & 3.82 & $<.500$ & $<.500$ & $<.500$ & 70.5 \\
\hline$I-20$ & $<.800$ & 4.80 & .928 & $<5.00$ & $<.500$ & 79.9 \\
\hline$I-2 I$ & 2.75 & 15.9 & .830 & $<5.00$ & .505 & 126 \\
\hline$I-21$ & $<.800$ & 16.4 & 1.39 & $<5.00$ & $<.500$ & 115 \\
\hline$I-2 I$ & $<.800$ & 12.4 & $<.500$ & $<5.00$ & $<.500$ & 101 \\
\hline$I-2 I$ & $<.800$ & 20.8 & 1.39 & $<5.00$ & $<.500$ & 93.1 \\
\hline$I-21$ & $<.800$ & 22.7 & .906 & $<5.00$ & $<.500$ & 116 \\
\hline$I-21$ & $<.800$ & 6.49 & .922 & $<5.00$ & $<.500$ & 83.8 \\
\hline$I-23$ & $<.800$ & 5.92 & 1.50 & $<5.00$ & .761 & 174 \\
\hline$I-23$ & $<.800$ & 12.0 & .711 & $<5.00$ & 2.31 & 124 \\
\hline$I-23$ & $<.800$ & 3.83 & 1.08 & $<5.00$ & $<.500$ & 195 \\
\hline$I-23$ & $<.800$ & 4.12 & .753 & $<5.00$ & .520 & 273 \\
\hline$I-23$ & $<.800$ & 9.47 & 4.21 & $<5.00$ & .869 & 154 \\
\hline$I-23$ & $<.800$ & 8.94 & 1.48 & $<5.00$ & $<.500$ & 92.6 \\
\hline
\end{tabular}


Table 26.--Concentrations of selected constituents in livers and kidneys of bird samples: spring 1990-Continued

\begin{tabular}{|c|c|c|c|c|c|c|c|}
\hline $\begin{array}{c}\text { Site } \\
\text { number }\end{array}$ & Date & species & $I / C$ & $\begin{array}{l}\text { Weight } \\
\text { (grams) }\end{array}$ & $\begin{array}{l}\text { Aluminum } \\
\text { (Al) }\end{array}$ & $\begin{array}{c}\text { Antimony } \\
\text { (Sb) }\end{array}$ & $\begin{array}{c}\text { Arsen } \\
\text { (As) }\end{array}$ \\
\hline & \multicolumn{7}{|c|}{ Juvenile birds } \\
\hline$I-6$ & $06-05-90$ & Mallard & $C(2)$ & 7.3 & 6.11 & $<5.00$ & $<0.3$ \\
\hline$I-9$ & $06-05-90$ & Mallard & $C(2)$ & 8.0 & 8.91 & $<5.00$ & $<.3$ \\
\hline$I-10$ & $06-05-90$ & Mallard & $C(2)$ & 25.0 & 28.2 & $<5.00$ & $<.3$ \\
\hline \multirow[t]{2}{*}{$I-10$} & $06-05-90$ & Mallard & I & 29.0 & 46.8 & $<5.00$ & $<.3$ \\
\hline & \multicolumn{7}{|c|}{ Eggs } \\
\hline$I-6$ & $06-05-90$ & Mallard & I & 30.0 & $<2.00$ & $<5.00$ & $<0.3$ \\
\hline$I-9$ & $06-05-90$ & Avocet & I & 26.5 & $<2.00$ & $<5.00$ & $<.3$ \\
\hline$I-10$ & $06-05-90$ & Avocet & I & 26.4 & $<2.00$ & $<5.00$ & $<.3$ \\
\hline$I-10$ & $06-05-90$ & Avocet & $C(2)$ & 9.0 & $<2.00$ & $<5.00$ & $<.3$ \\
\hline$I-11$ & $06-05-90$ & Avocet & I & 27.8 & $<2.00$ & $<5.00$ & $<.3$ \\
\hline$I-12$ & $06-13-90$ & Avocet & $C(2)$ & 43.0 & $<2.00$ & $<5.00$ & $<.3$ \\
\hline$I-16$ & $06-11-90$ & Killdeer & $C(2)$ & 8.0 & $<2.00$ & $<5.00$ & $<.3$ \\
\hline$I-17$ & $06-08-90$ & Killdeer & I & 5.0 & $<2.00$ & $<5.00$ & $<.3$ \\
\hline$I-2 I$ & $06-14-90$ & Cinnamon Teal & $c(3)$ & 18.5 & $<2.00$ & $<5.00$ & $<.3$ \\
\hline$I-23$ & $06-06-90$ & Coot & I & 23.0 & $<2.00$ & $<5.00$ & $<.3$ \\
\hline$I-23$ & $06-06-90$ & Coot & I & 22.5 & $<2.00$ & $<5.00$ & $<.3$ \\
\hline$I-23$ & $06-06-90$ & Coot & I & 20.7 & $<2.00$ & $<5.00$ & $<.3$ \\
\hline$I-23$ & $06-06-90$ & Coot & I & 22.7 & $<2.00$ & $<5.00$ & $<.3$ \\
\hline
\end{tabular}


Table 26.--Concentrations of selected constituents in livers and kidneys of bird samples: spring 1990-Continued

\begin{tabular}{|c|c|c|c|c|c|c|c|}
\hline $\begin{array}{l}\text { Site } \\
\text { number }\end{array}$ & $\begin{array}{l}\text { Barium } \\
\text { (Ba) }\end{array}$ & $\begin{array}{l}\text { Beryllium } \\
\text { (Be) }\end{array}$ & $\begin{array}{l}\text { Boron } \\
\text { (B) }\end{array}$ & $\begin{array}{l}\text { Cadmium } \\
\text { (Cd) }\end{array}$ & $\begin{array}{l}\text { Chromium } \\
\text { (Cr) }\end{array}$ & $\begin{array}{l}\text { Cobalt } \\
\text { (Co) }\end{array}$ & $\begin{array}{c}\text { Copper } \\
\text { (Cu) }\end{array}$ \\
\hline \multicolumn{8}{|c|}{ Juvenile birds } \\
\hline$I-6$ & 0.545 & $<0.100$ & 1.22 & 0.105 & 0.671 & $<0.500$ & 46.9 \\
\hline$I-9$ & 1.23 & $<.100$ & 1.66 & $<.100$ & .827 & $<.500$ & 12.1 \\
\hline$I-10$ & 4.18 & $<.100$ & 1.25 & $<.100$ & .686 & $<.500$ & 19.2 \\
\hline$I-10$ & 1.53 & $<.100$ & 3.42 & $<.100$ & .657 & $<.500$ & 11.2 \\
\hline \multicolumn{8}{|c|}{ Eggs } \\
\hline$I-6$ & 12.9 & $<0.100$ & 0.855 & $<0.100$ & $<0.500$ & $<0.500$ & 4.71 \\
\hline$I-9$ & 43.6 & $<.100$ & 2.57 & $<.100$ & .954 & $<.500$ & 4.82 \\
\hline$I-10$ & 5.52 & $<.100$ & .789 & $<.100$ & $<.500$ & $<.500$ & 5.03 \\
\hline$I-10$ & 48.4 & $<.100$ & .866 & $<.100$ & .633 & $<.500$ & 3.21 \\
\hline$I-11$ & 25.3 & $<.100$ & 1.40 & $<.100$ & $<.500$ & $<.500$ & 4.08 \\
\hline$I-12$ & 8.47 & $<.100$ & 1.14 & $<.100$ & $<.500$ & $<.500$ & 4.33 \\
\hline$I-16$ & 6.67 & $<.100$ & $<.500$ & $<.100$ & 1.30 & $<.500$ & 1.60 \\
\hline$I-17$ & 4.33 & $<.100$ & 1.14 & $<.100$ & $<.500$ & $<.500$ & 3.48 \\
\hline$I-21$ & 16.0 & $<.100$ & .892 & $<.100$ & $<.500$ & $<.500$ & 4.66 \\
\hline$I-23$ & 3.90 & $<.100$ & 2.24 & $<.100$ & $<.500$ & $<.500$ & 4.46 \\
\hline$I-23$ & 6.91 & $<.100$ & 1.98 & $<.100$ & $<.500$ & $<.500$ & 4.26 \\
\hline$I-23$ & 1.29 & $<.100$ & 1.40 & $<.100$ & $<.500$ & $<.500$ & 4.80 \\
\hline$I-23$ & 5.16 & $<.100$ & 1.45 & $<.100$ & $<.500$ & $<.500$ & 3.80 \\
\hline
\end{tabular}


Table 26.--Concentrations of selected constituents in livers and kidneys of bird samples: spring 1990-Continued

\begin{tabular}{|c|c|c|c|c|c|c|}
\hline $\begin{array}{l}\text { Site } \\
\text { number }\end{array}$ & $\begin{array}{l}\text { Iron } \\
\text { (Fe) }\end{array}$ & $\begin{array}{l}\text { Lead } \\
(\mathrm{Pb})\end{array}$ & $\begin{array}{l}\text { Magnesium } \\
\text { (Mg) }\end{array}$ & $\begin{array}{c}\text { Manganese } \\
(\mathrm{Mn})\end{array}$ & $\begin{array}{l}\text { Mercury } \\
\text { (Hg) }\end{array}$ & $\begin{array}{l}\text { Molybdenum } \\
\text { (Mo) }\end{array}$ \\
\hline \multicolumn{7}{|c|}{ Juvenile birds } \\
\hline$I-6$ & 715 & $<0.2$ & 1,050 & 20.3 & 0.348 & 2.34 \\
\hline$I-9$ & 1,700 & $<.2$ & 977 & 16.7 & .446 & 3.14 \\
\hline$I-10$ & 1,300 & .273 & 991 & 20.1 & .0398 & 3.25 \\
\hline$I-10$ & 3,610 & .445 & 924 & 18.7 & .164 & 4.21 \\
\hline \multicolumn{7}{|c|}{ Eggs } \\
\hline$I-6$ & 127 & $<0.2$ & 516 & 4.73 & 0.345 & $<0.800$ \\
\hline I-9 & 163 & .349 & 521 & 3.22 & .407 & $<.800$ \\
\hline$I-10$ & 119 & $<.2$ & 484 & 2.26 & .399 & $<.800$ \\
\hline$I-10$ & 189 & $<.2$ & 306 & 3.65 & $<.02$ & $<.800$ \\
\hline$I-11$ & 135 & .332 & 475 & 1.58 & .311 & $<.800$ \\
\hline$I-12$ & 161 & $<.2$ & 420 & 2.95 & .449 & $<.800$ \\
\hline$I-16$ & 138 & $<.2$ & 305 & 4.47 & $<.02$ & $<.800$ \\
\hline $\mathrm{I}-17$ & 187 & $<.2$ & 553 & 2.77 & $<.02$ & $<.800$ \\
\hline$I-21$ & 237 & $<.2$ & 246 & 6.06 & $<.02$ & $<.800$ \\
\hline$I-23$ & 149 & .620 & 680 & 3.30 & $<.02$ & $<.800$ \\
\hline$I-23$ & 116 & $<.2$ & 800 & 2.96 & $<.02$ & $<.800$ \\
\hline$I-23$ & 85.4 & $<.2$ & 613 & 7.56 & .0884 & 1.20 \\
\hline$I-23$ & 123 & $<.2$ & 588 & 6.22 & .0699 & $<.800$ \\
\hline
\end{tabular}


Table 26.--Concentrations of selected constituents in livers and kidneys of bird samples: spring 1990-Concluded

\begin{tabular}{|c|c|c|c|c|c|c|}
\hline $\begin{array}{c}\text { Site } \\
\text { number }\end{array}$ & $\begin{array}{l}\text { Nickel } \\
\text { (Ni) }\end{array}$ & $\begin{array}{l}\text { Selenium } \\
\text { (Se) }\end{array}$ & $\begin{array}{l}\text { Strontium } \\
\text { (Sr) }\end{array}$ & $\begin{array}{l}\text { Tin } \\
(S n)\end{array}$ & $\begin{array}{l}\text { Vanadium } \\
\text { (V) }\end{array}$ & $\begin{array}{l}\text { Zinc } \\
(2 n)\end{array}$ \\
\hline & \multicolumn{6}{|c|}{ Juvenile birds } \\
\hline$I-6$ & $<0.800$ & 28.2 & 2.47 & $<5.00$ & $<0.500$ & 118 \\
\hline$I-9$ & $<.800$ & 5.79 & 1.22 & $<5.00$ & $<.500$ & 104 \\
\hline$I-10$ & $<.800$ & 21.4 & 8.12 & $<5.00$ & $<.500$ & 161 \\
\hline \multirow[t]{2}{*}{$I-10$} & $<.800$ & 9.83 & 1.69 & $<5.00$ & $<.500$ & 119 \\
\hline & \multicolumn{6}{|c|}{ Eggs } \\
\hline$I-6$ & $<0.800$ & 17.6 & 79.0 & $<5.00$ & $<0.500$ & 66.0 \\
\hline$I-9$ & $<.800$ & 2.64 & 26.0 & $<5.00$ & $<.500$ & 62.0 \\
\hline$I-10$ & $<.800$ & 3.63 & 19.7 & $<5.00$ & $<.500$ & 46.4 \\
\hline$I-10$ & $<.800$ & 2.95 & 22.2 & $<5.00$ & $<.500$ & 68.1 \\
\hline$I-11$ & $<.800$ & 3.76 & 12.6 & $<5.00$ & $<.500$ & 47.8 \\
\hline$I-12$ & $<.800$ & 2.91 & 17.4 & $<5.00$ & $<.500$ & 60.2 \\
\hline$I-16$ & $<.800$ & 2.77 & 15.9 & $<.500$ & $<.500$ & 51.7 \\
\hline$I-17$ & $<.800$ & 2.08 & 60.1 & $<.500$ & $<.500$ & 68.4 \\
\hline$I-2 I$ & $<.800$ & 4.83 & 23.0 & $<5.00$ & $<.500$ & 93.7 \\
\hline$I-23$ & $<.800$ & 2.37 & 34.3 & $<.500$ & $<.500$ & 81.1 \\
\hline$I-23$ & $<.800$ & 2.48 & 43.1 & $<.500$ & $<.500$ & 77.5 \\
\hline$I-23$ & $<.800$ & 1.87 & 13.5 & $<.500$ & $<.500$ & 60.9 \\
\hline$I-23$ & $<.800$ & 1.65 & 23.8 & $<.500$ & $<.500$ & 64.3 \\
\hline
\end{tabular}




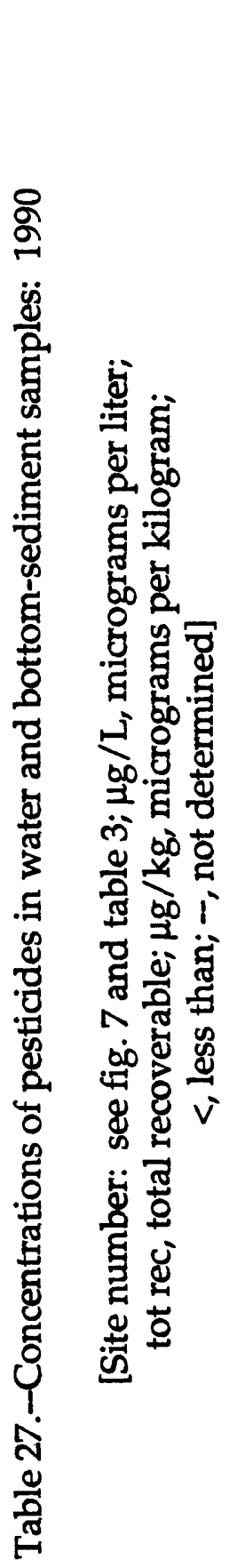

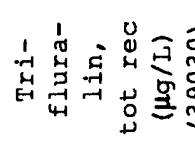

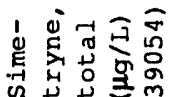

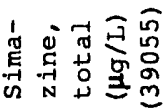

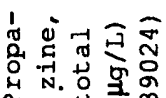

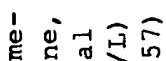

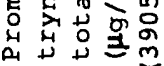

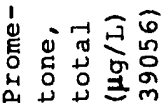

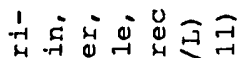

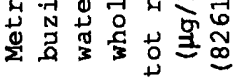

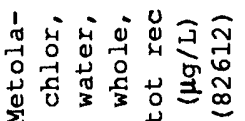

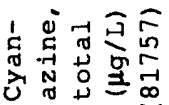

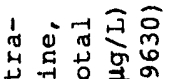

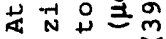

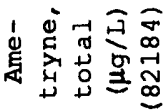

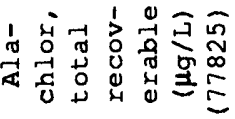

兽

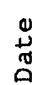

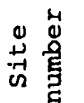

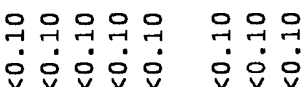

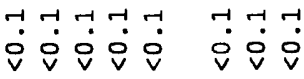

욱욱욱우국 욱우우

ioivi ivi

욱우욱우우 욱우웅

ivioi ivi

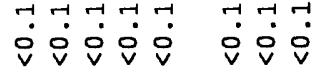

ưv

g

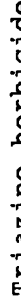

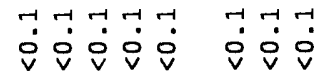

․ㅜㄱ우우국 우ㄱㅜㅜㄱㅜ

Noogi io

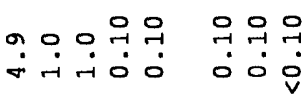

욱우욱우우 욱으ㄱㅜㅜ

i $\dot{v} \dot{i} \dot{i} \quad \dot{i} \dot{v}$

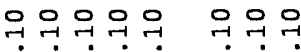

i $i_{i} \dot{i}$ i

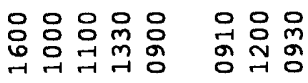

음응응ㅇㅇㅇㅇㅇㅇㅇㅇ

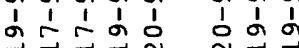

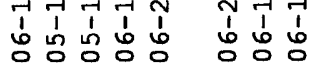

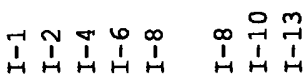




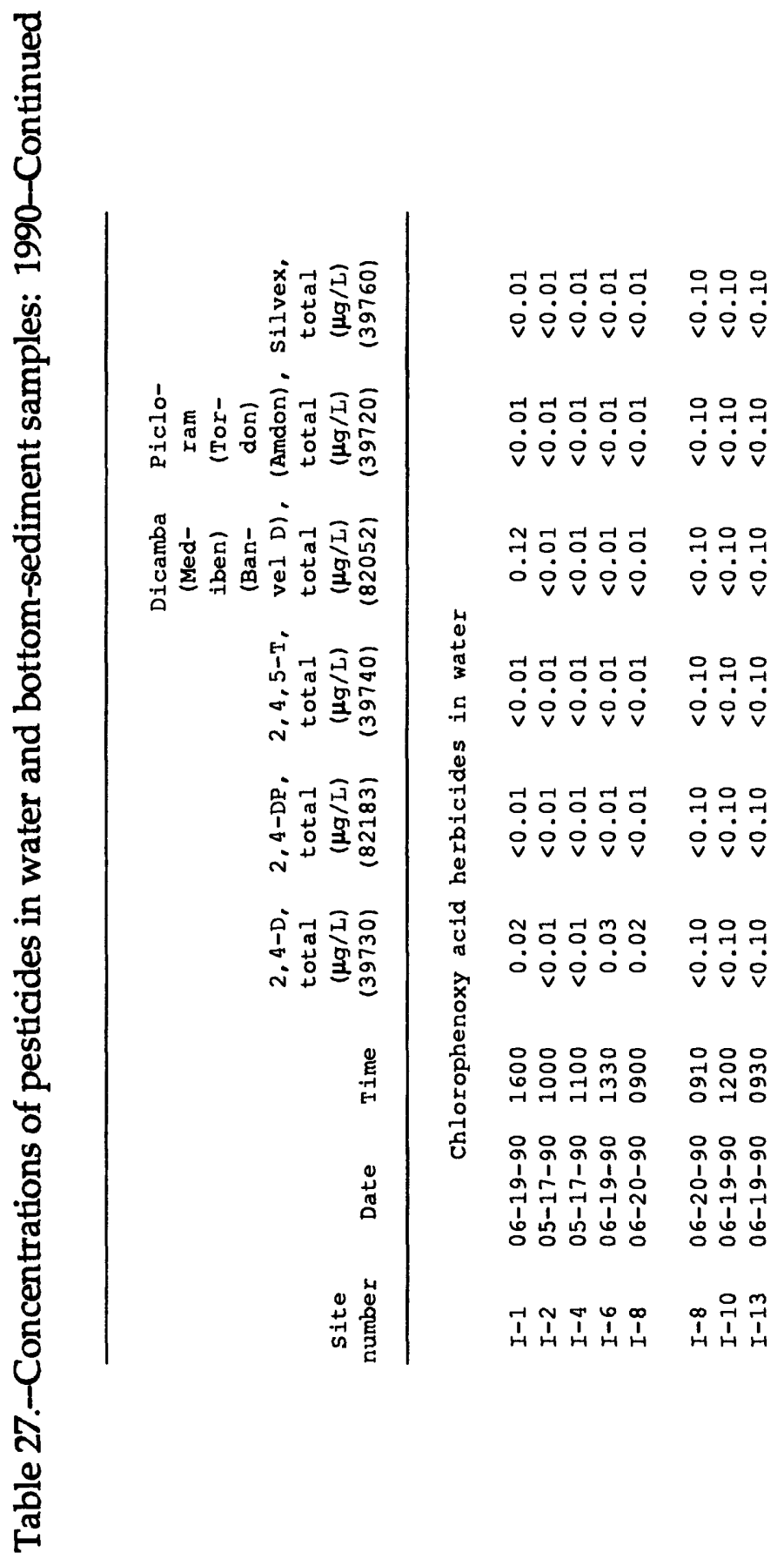




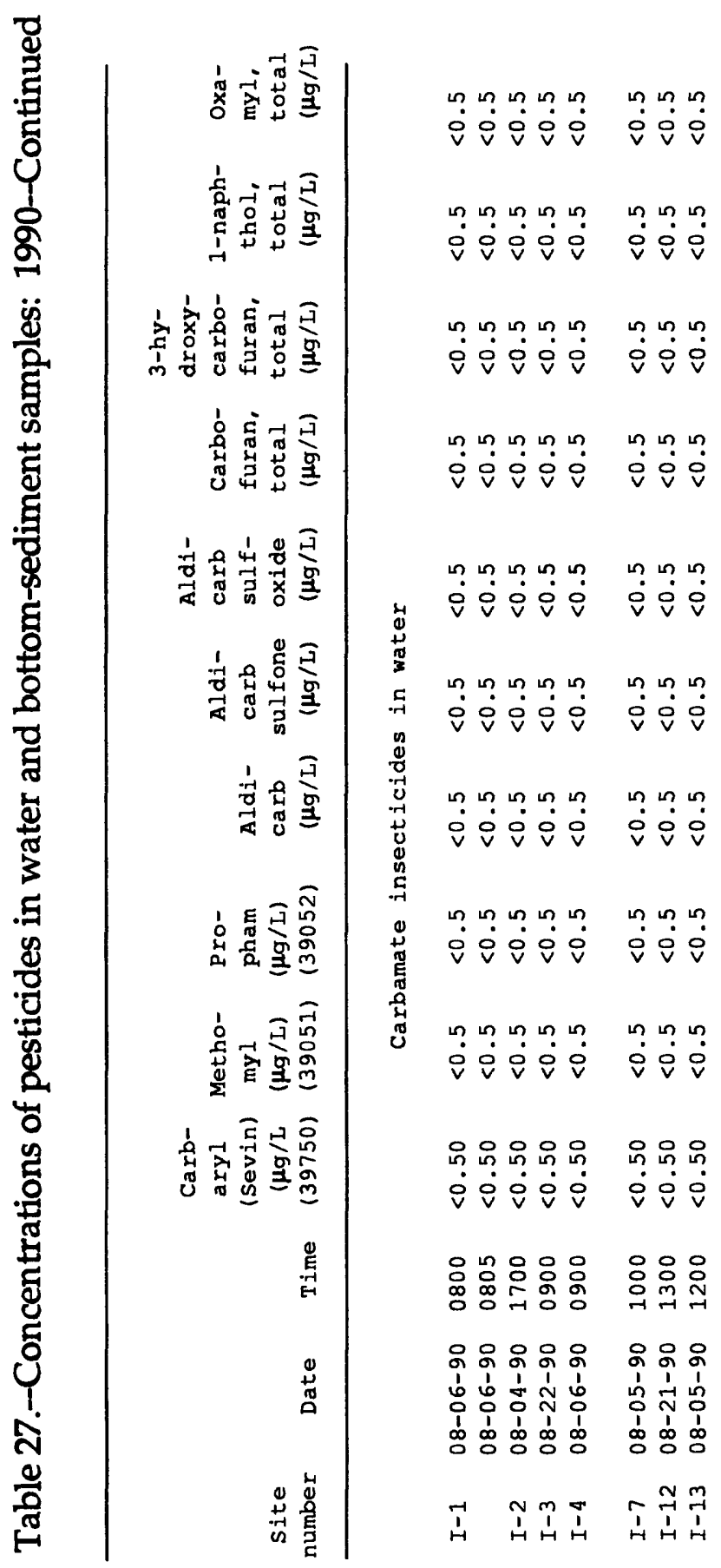




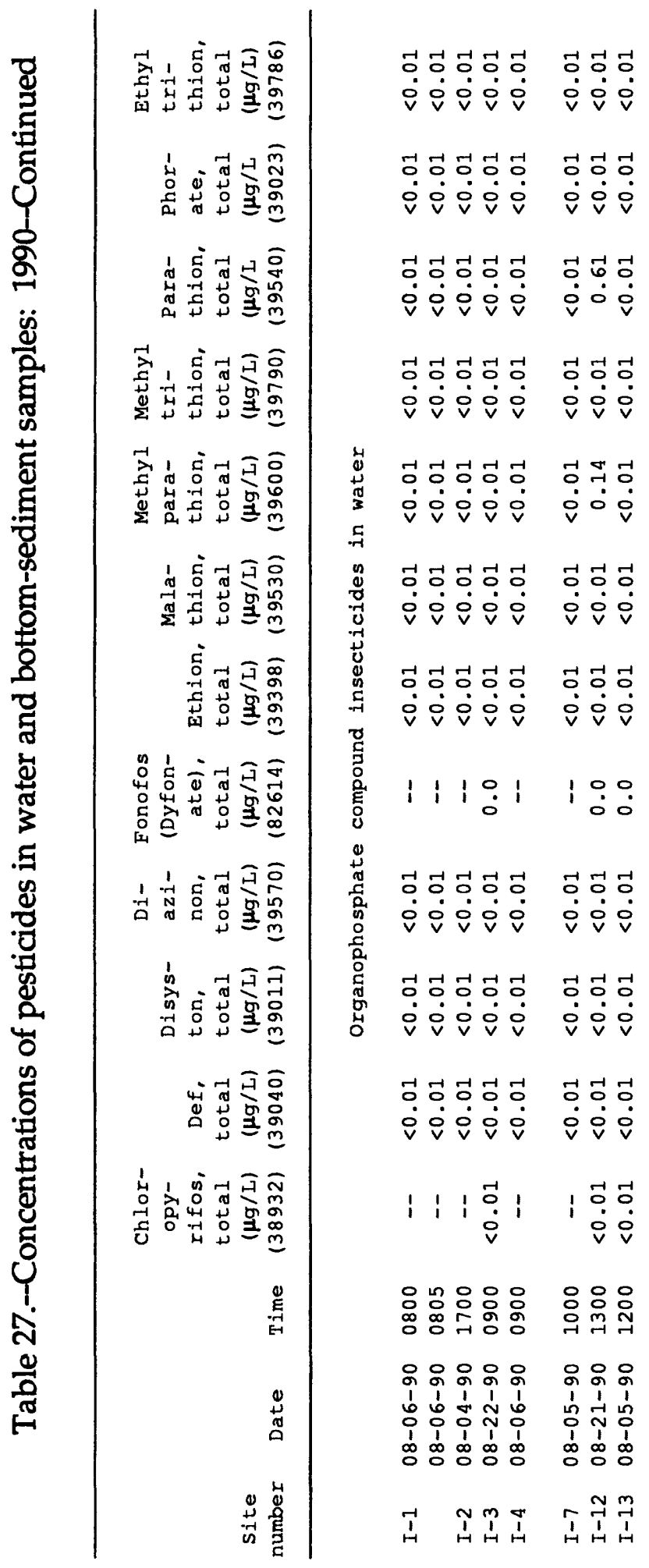




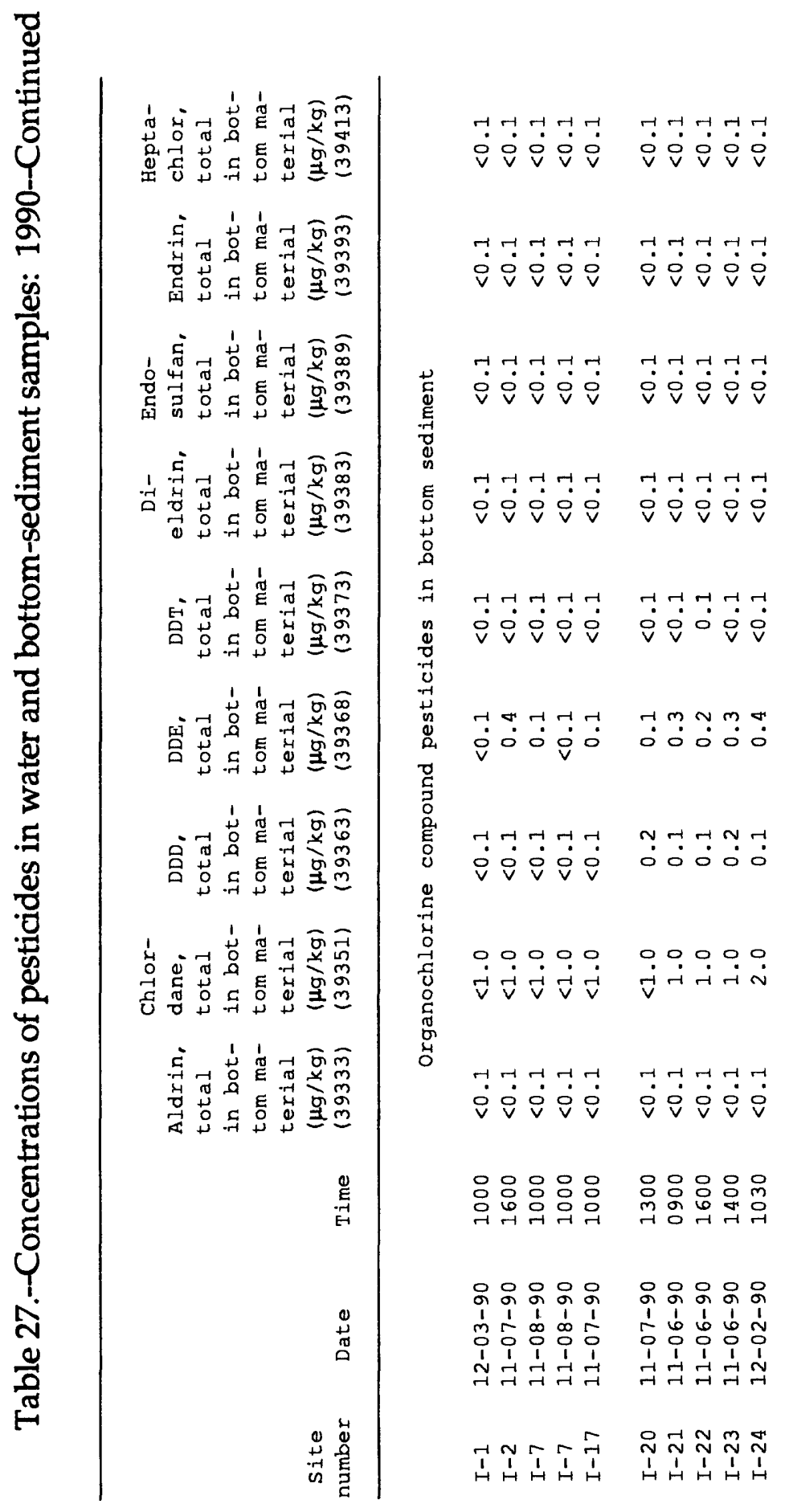




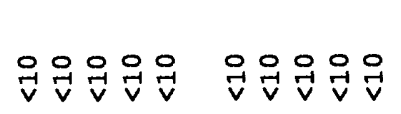

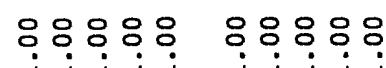
$\dot{\vec{v} \dot{v}} \dot{\vec{v}} \dot{\vec{v}} \dot{\vec{v}} \dot{\vec{v}} \dot{\vec{v}} \dot{\vec{v}} \dot{v} \dot{v}$

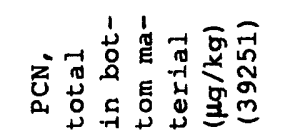

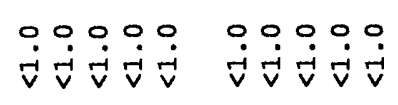

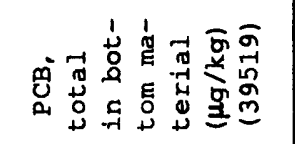

$\vec{v} \vec{v} \vec{v} \vec{v} \quad \vec{v} \vec{v} \vec{v} \vec{v}$

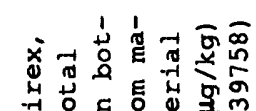

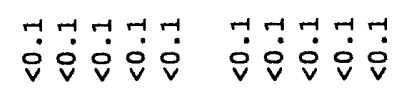

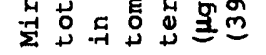

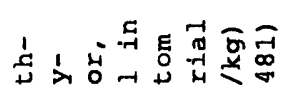

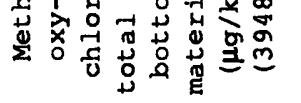

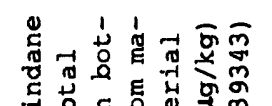

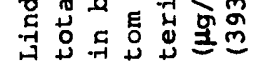

की

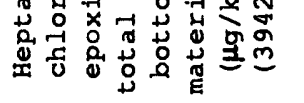

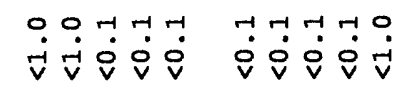

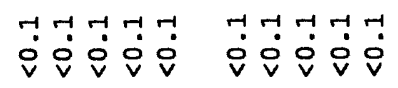

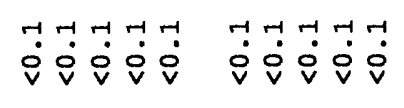

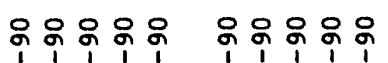

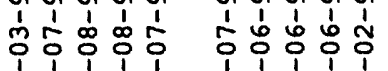

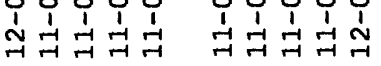

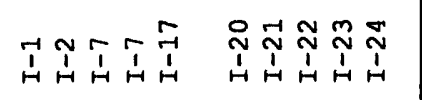

䒕 


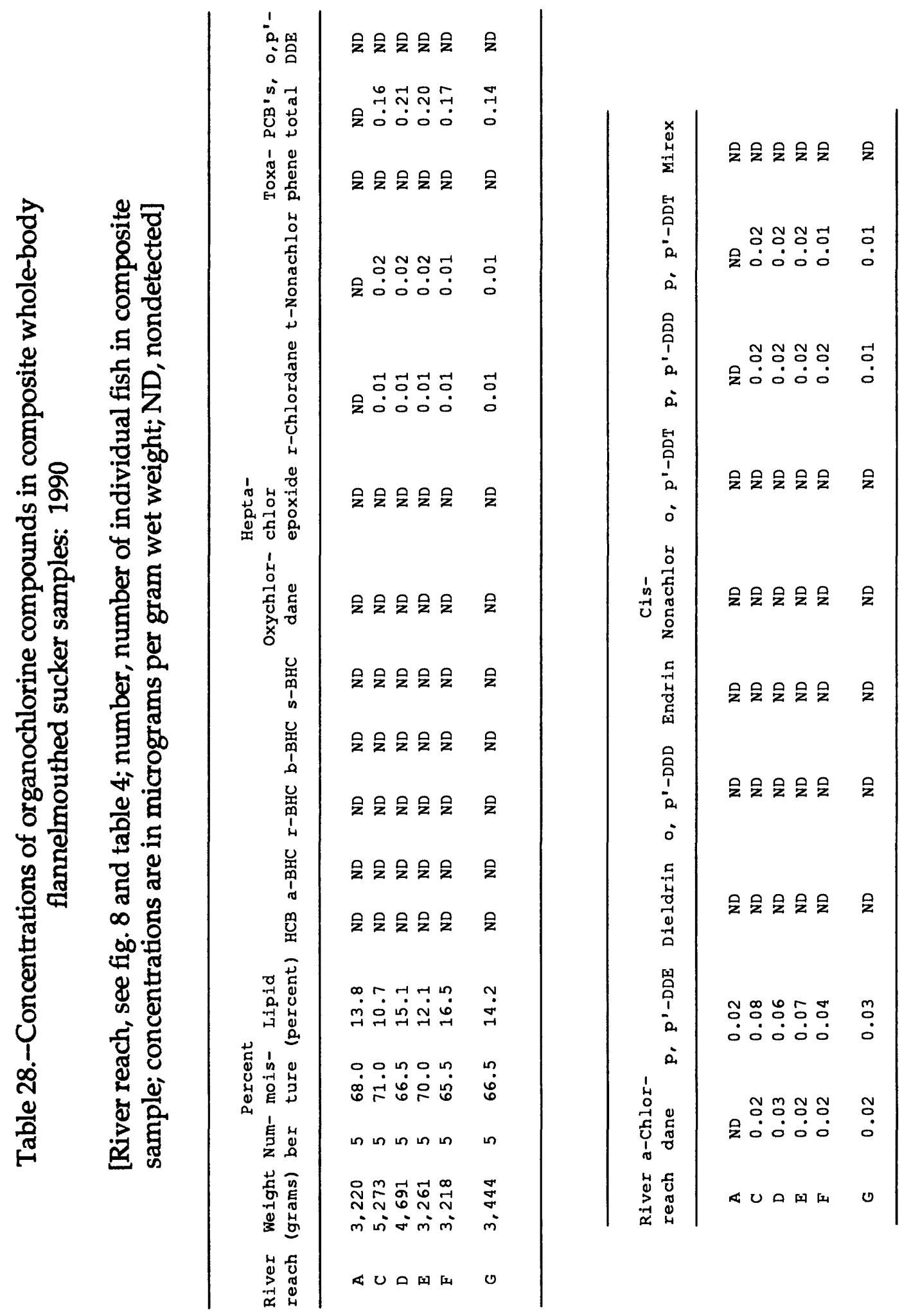




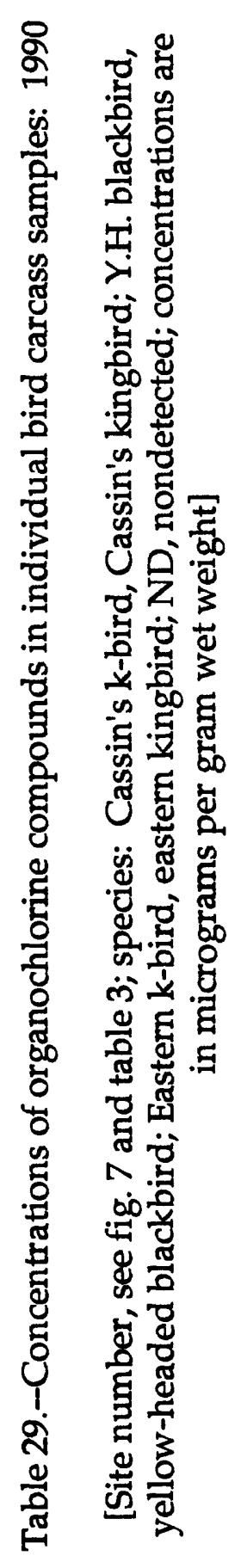

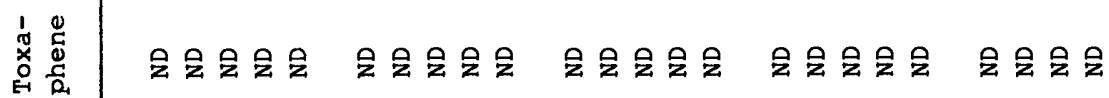

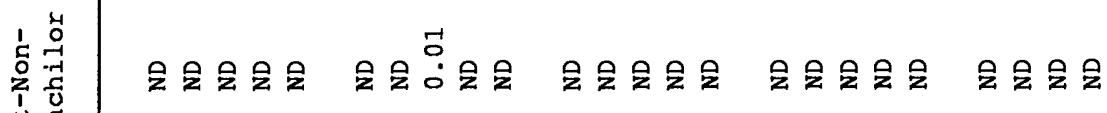
究

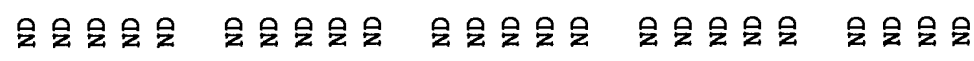

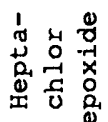

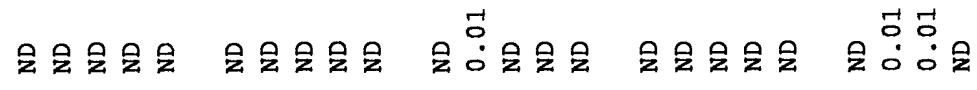
닐

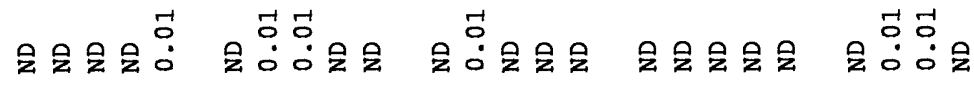

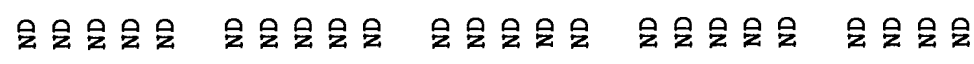

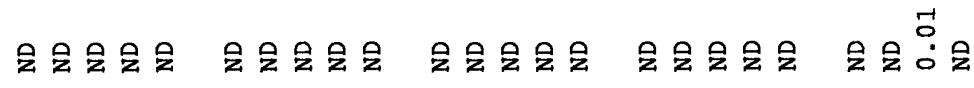

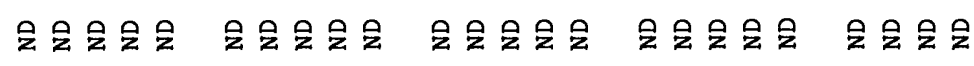

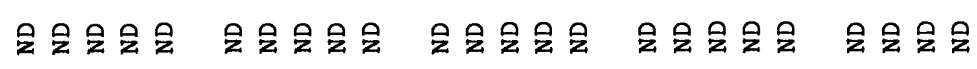

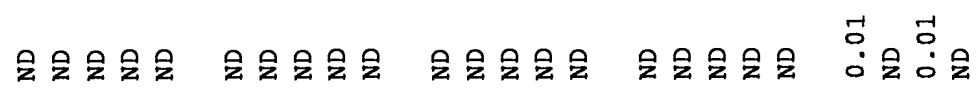

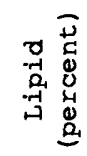

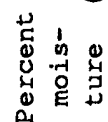

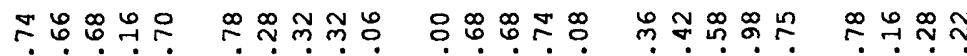

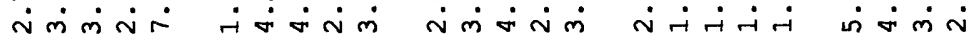

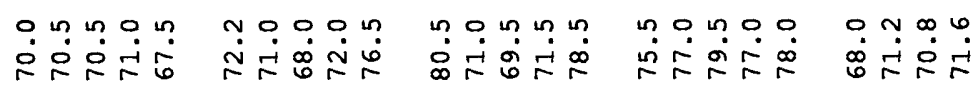
䆑高

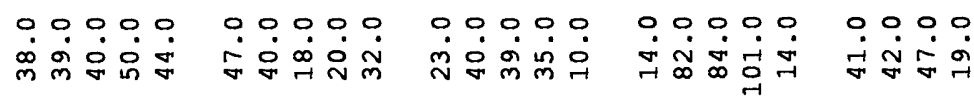

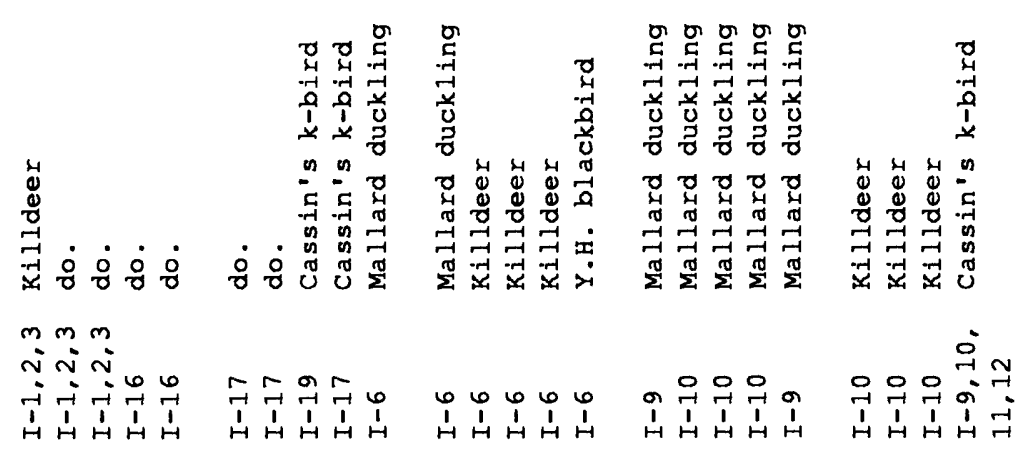




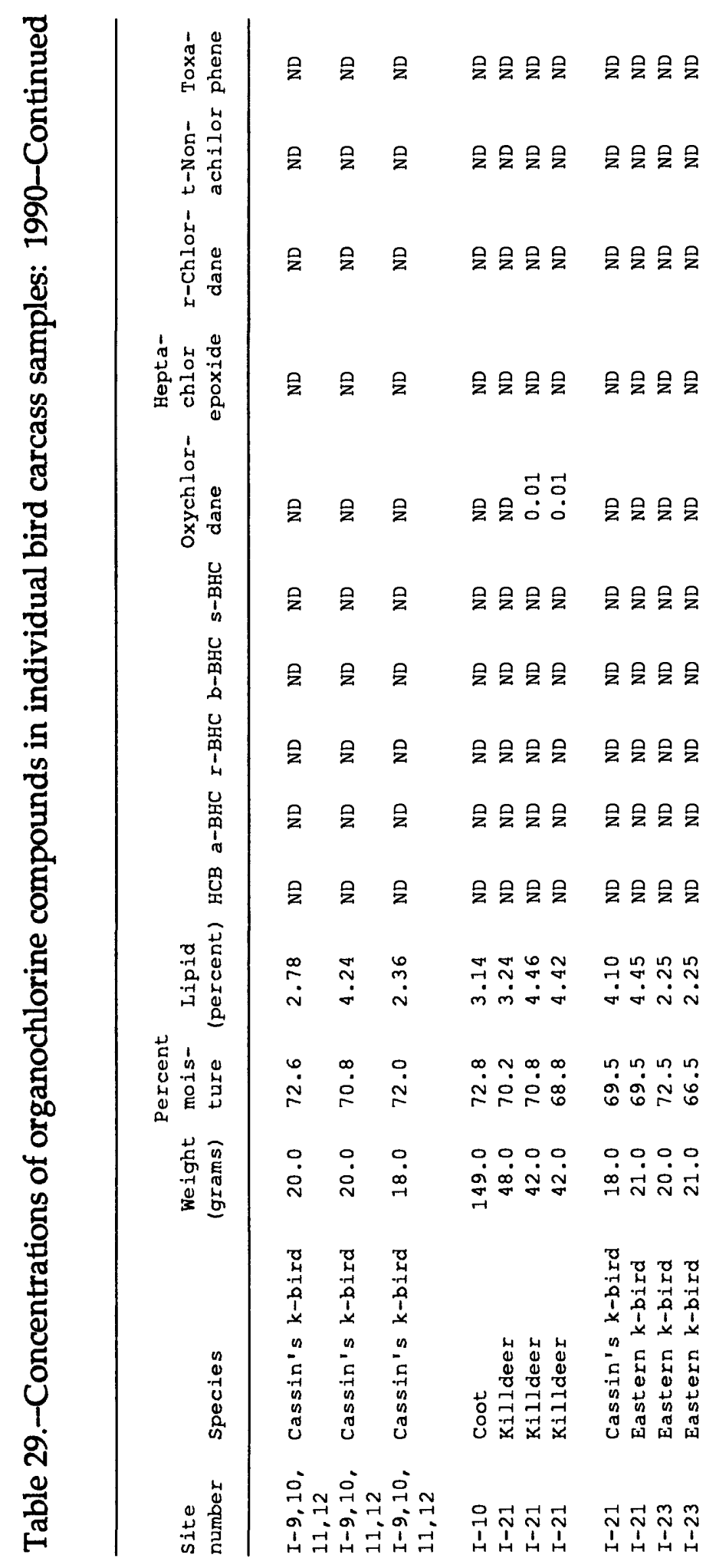




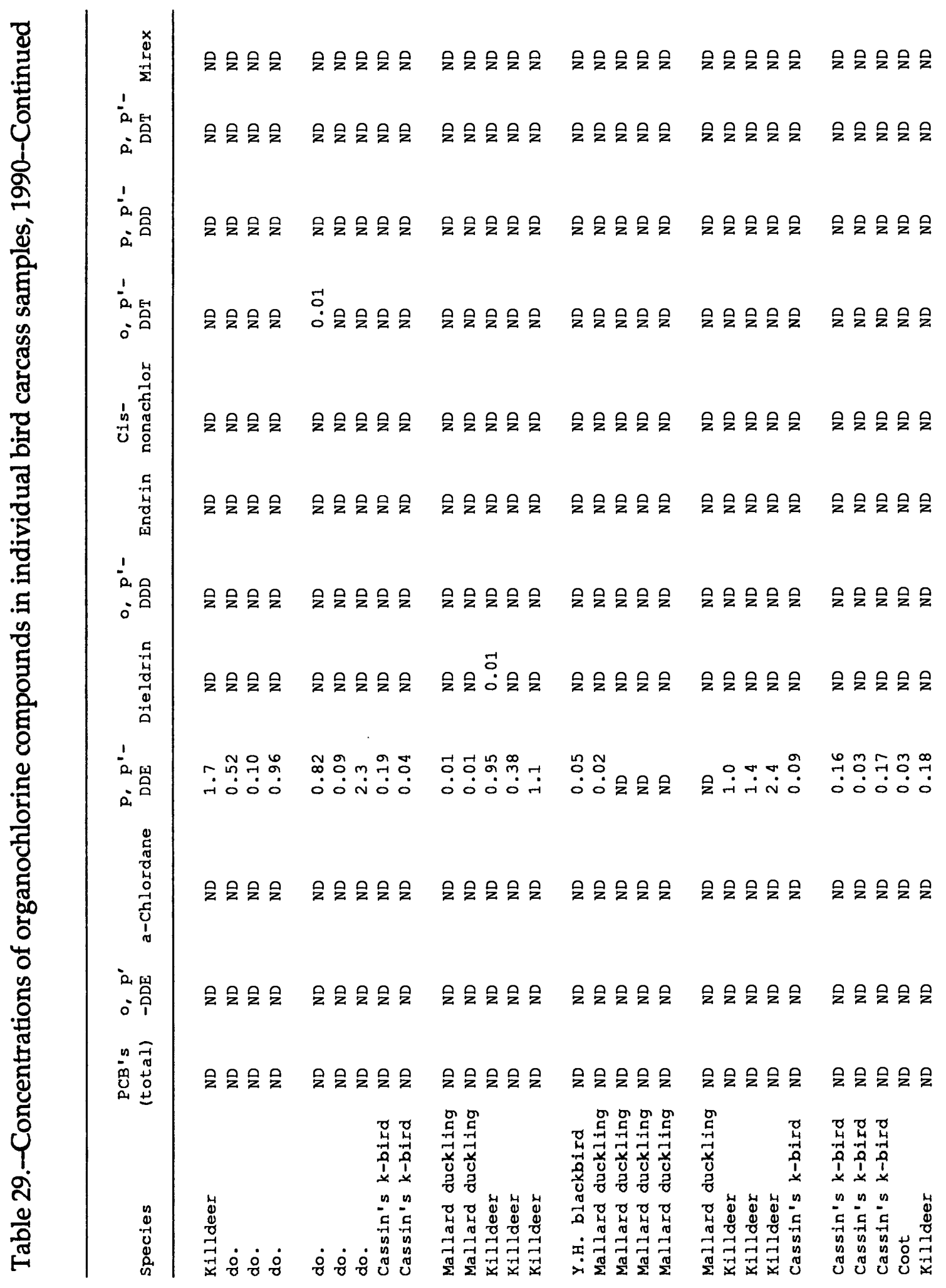




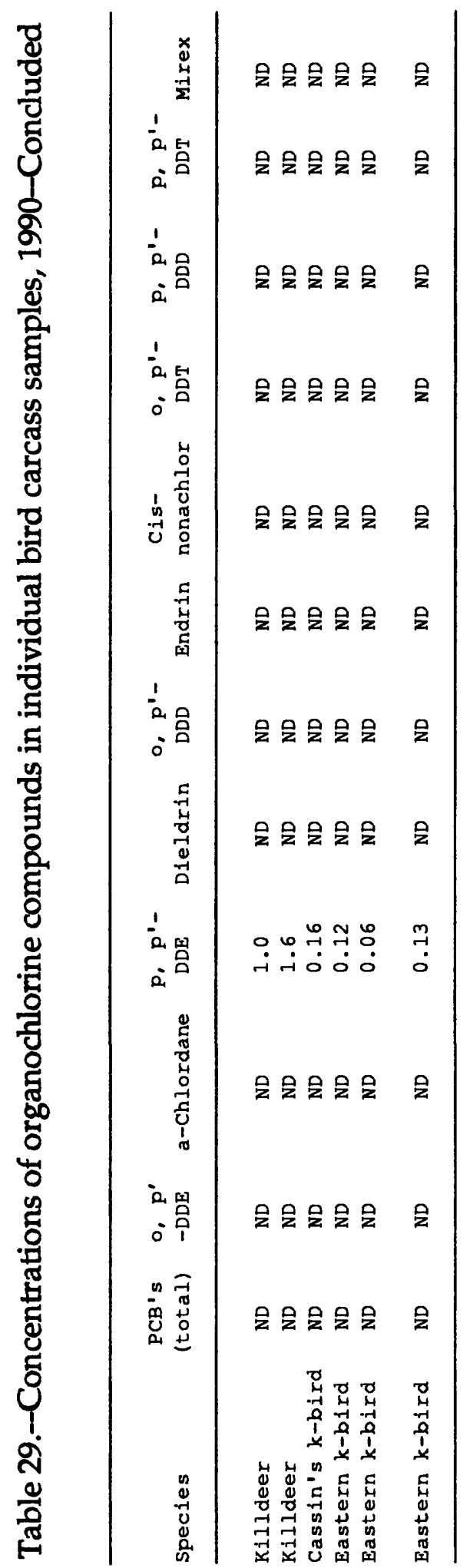




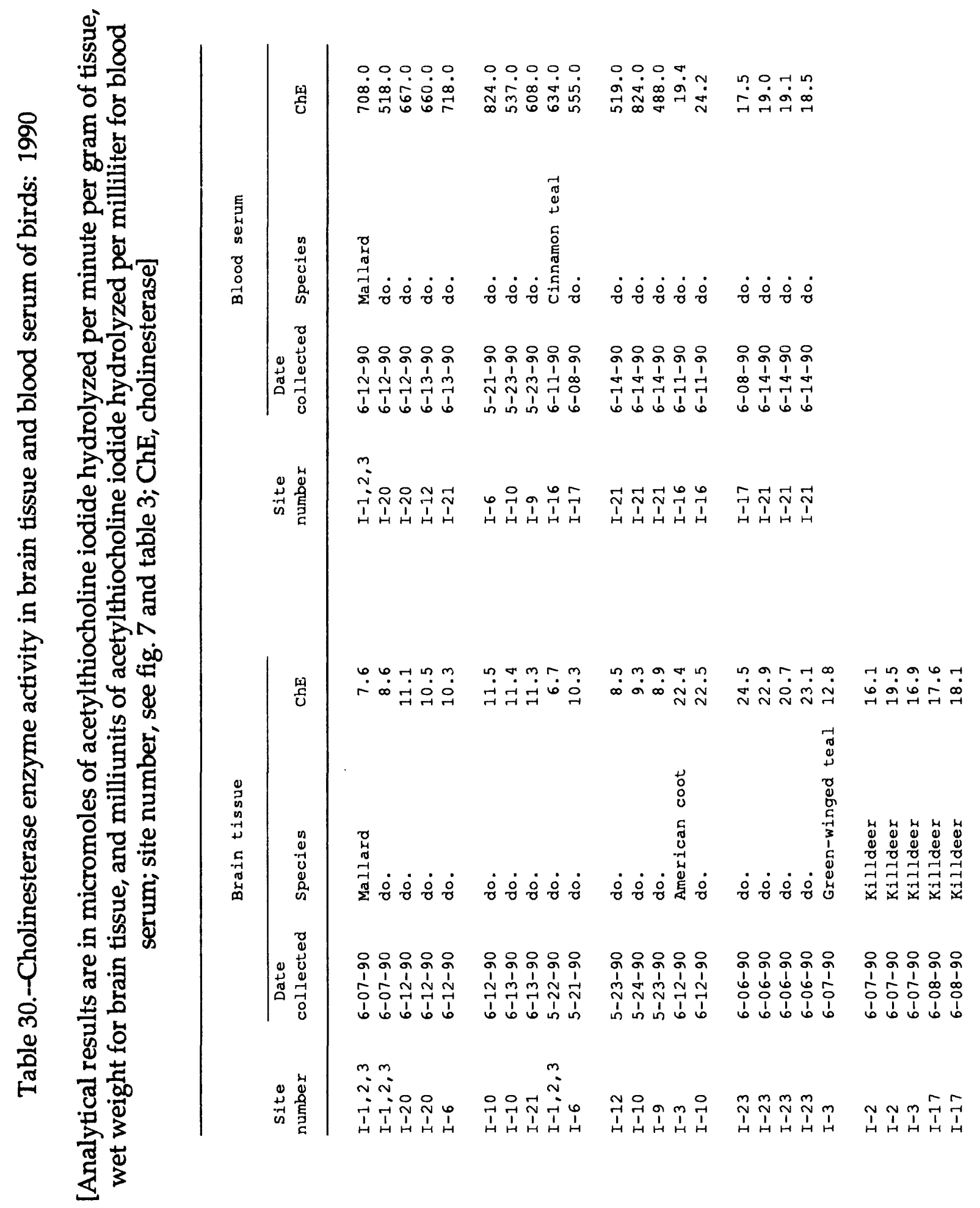




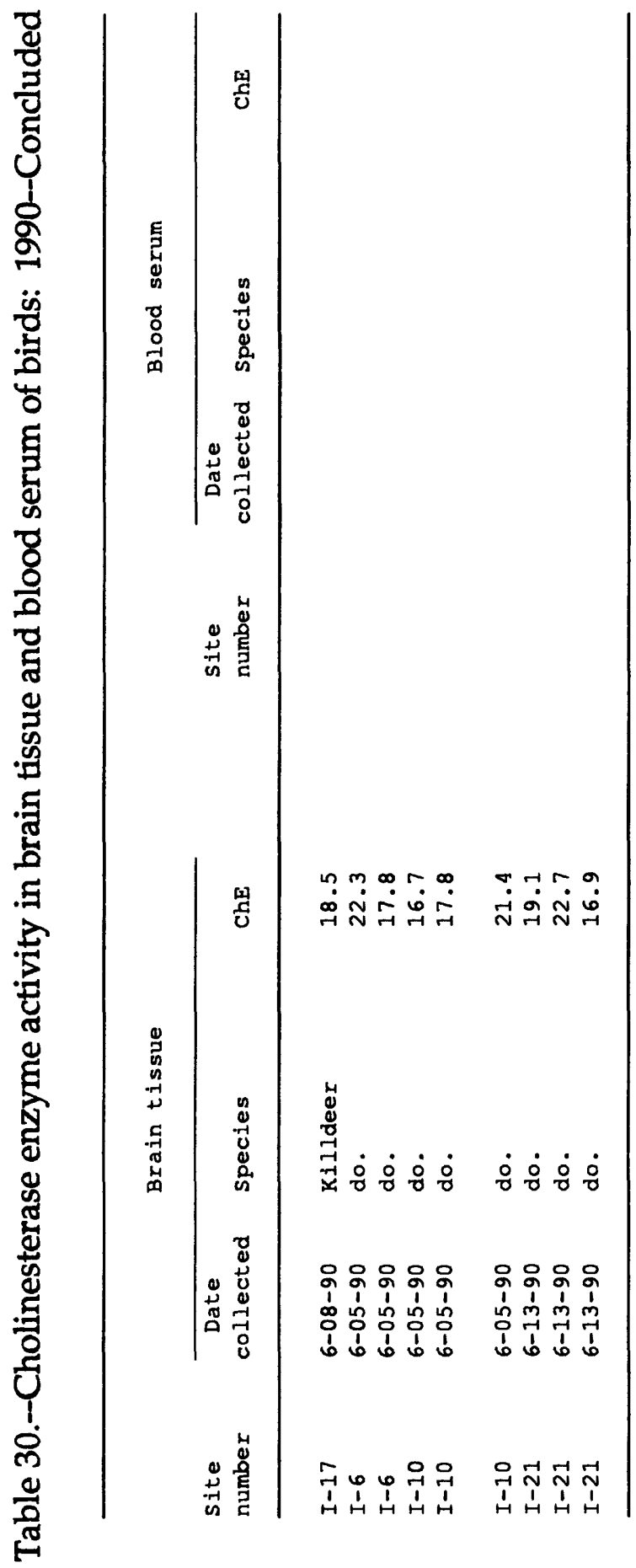

